GÖTTINGER ZENTRUM

FÜR BIODIVERSITÄTSFORSCHUNG UND ÖKOLOGIE

- Göttingen Centre for Biodiversity ANd Ecology -

\title{
Taxonomy and Phylogeny of the Liverwort Genus Thysananthus (Marchantiophyta: Lejeuneaceae)
}

\author{
Dissertation zur Erlangung des Doktorgrades der \\ Mathematisch-Naturwissenschaftlichen Fakultäten der \\ Georg-August-Universität Göttingen
}

vorgelegt von

M.Sc. Botany

Phiangphak Sukkharak

aus

Nan, Thailand

Göttingen, June, 2011 
Referentin/Referent:

Korreferentin/Korreferent:
Prof. Dr. S. Robbert Gradstein

PD Dr. Michael Stech

Tag der mündlichen Prüfung: 


\section{CONTENTS}

Acknowledgements

$\begin{array}{ll}\text { Abstract } & \text { iii }\end{array}$

Zusammenfassung $\quad$ iv

I. Synopsis

IA. Introduction 1

Introduction to Lejeuneaceae 1

Introduction to Thysananthus 2

Morphological and anatomical study 3

Chemical study 4

Phylogenetic study 4

Monograph of Thysananthus subgenus Thysananthus 5

$\begin{array}{ll}\text { IB. General discussion } & 6\end{array}$

Future Prospects 9

$\begin{array}{ll}\text { References } & 10\end{array}$

II. Studies on the genus Thysananthus (Marchantiophyta: Lejeuneaceae) 1. 14

Thysananthus discretus Sukkharak et Gradst. sp. nov.

Phiangphak Sukkharak and S. Robbert Gradstein

III. On the occurrence of adnate underleaves and appendages in Thysananthus

(Lejeuneaceae). Studies on the genus Thysananthus, 2

Phiangphak Sukkharak and S. Robbert Gradstein

IV. Studies on the genus Thysananthus (Marchantiophyta, Lejeuneaceae) 3.

Terpenoid chemistry and chemotaxonomy of selected species of Thysananthus and Dendrolejeunea fruticosa

Phiangphak Sukkharak, Agnieszka Ludwiczuk, Yoshinori Asakawa and S. Robbert 
Gradstein

V. Phylogeny, taxon circumscriptions and character evolution in the core

Ptychanthoideae (Marchantiophyta: Lejeuneaceae)

Phiangphak Sukkharak, S. Robbert Gradstein and Michael Stech

VI. Monograph of Thysananthus subgenus Thysananthus (Lejeuneaceae,

Marchantiophyta)

Phiangphak Sukkharak

Declaration of the author's own contribution to manuscripts

Curriculum Vitae 


\section{ACKNOWLEDGEMENTS}

I would like to thank my supervisor, Prof. Dr. S. Robbert Gradstein for giving me the opportunity to study at the department of Systematic Botany. The present study was initiated since July 2007 when I met him at the "World Conference of Bryology" in Kuala Lumpur, Malaysia and was invited to Göttingen for a PhD study under his guidance. I express my gratitude to him for his supervision, suggestions and many helpful discussions throughout the duration of my thesis. I am very grateful to PD Dr. Michael Stech as supervisor for my molecular work and being my co-referee. I would like to thank Dr. Agnieszka Ludwiczuk for being the co-author for my phytochemical paper and her hospitality upon my visit to her department. My study was supported by a Royal Thai government scholarship in cooperation with the German Academic Exchange Service (DAAD). Financial support from the Universitätsbund Göttingen for attending the conferences in Leiden, the Netherlands (2009), Singapore (2010) and Berlin, Germany (2011); the Royal Thai government scholarship for attending the conference in Melbourne, Australia (2011); the European Distributed Institute of Taxonomy (EDIT) grant for attending the Phylogenetic Systematics and Molecular Dating course in Copenhagen, Denmark (2011); and the SYNTHESYS Project for visiting Muséum National d'Histoire Naturelle in Paris, France (2011) are gratefully acknowledged. I express my gratitude to the directors and curators of the following herbaria for making the specimens available: Chulalongkorn University (BCU), National Park, Wildlife and Plant Conservation Department (BKF), The Natural History Museum (BM), National Botanic Garden of Belgium (BR), Herbarium Bogoriense (BZ), University of Copenhagen (C), Harvard University (FH), Conservatoire et Jardin botaniques de la Ville de Genève (G), Universität Göttingen (GOET), University of Helsinki (H), Hiroshima University (HIRO), Friedrich-Schiller-Universität Jena (JE), Nationaal Herbarium Nederland, Leiden University branch (L), Papua New Guinea Forest Research Institute (LAE), Hattori Botanical Laboratory (NICH), Royal Botanic Gardens (NSW), New York Botanical Garden (NY), Muséum National d'Histoire Naturelle (PC), Prince of Songkla University (PSU), Swedish Museum of Natural History (S), Singapore Botanic Gardens (SING), Institut de Botanique (STR), Nationaal Herbarium Nederland, Herbarium Utrecht (U) and Naturhistorisches Museum Wien (W). I am particularly indebted to Dr. Michel Hoff (Strasbourg, STR), Dr. Michelle J. Price (Geneva, G), Prof. Dr. Thaweesakdi Boonkerd (Bangkok, BCU), Dr. Rachun Pooma (Bangkok, BKF), Serena Lee (Singapore, SING), Dr. Herman Stieperaere (Meise, BR), Dr. Ruth Nielsen 
(Copenhagen, C), Bruno Dennetière (Paris, PC), and Len Ellis (London, BM) for their hospitality and generous assistance upon my visits to their institutions for the study of Thysananthus. Thanks are also due to M.C.M. Eurlings and the staff of DNAmarkerpoint (Leiden University) for technical assistance in molecular laboratory. I would like to thank Dr. Jochen Heinrichs, Dr. María Elena Reiner-Drehwald, Dr. Simone Klatt and all other staff at the department of Systematic Botany. Thanks also to Christine Gehrig-Downie for fresh liverwort material. I am also very grateful to Dr. Sahut Chantanaorrapint for fresh materials and field work. Special thanks go to Marc Appelhans for his helpful discussions and friendship over the years. Many thanks to Bernd Raufeisen, Dr. Boon-Chuan Ho, Ida Haerida, Jian Wang, Prof. Dr. Jan-Peter Frahm, Dr. Matt Renner, Prof. Dr. Rui-Liang Zhu, Soonthree Kornochalert and Thomas Hallingbäck. A big thank you to Thai students in Göttingen, especially Jakkrawadee Anuyotha and Sirinya Somching. My deepest thanks are to my family for their encouragement and support. 


\begin{abstract}
A systematic study of the liverwort genus Thysananthus, especially the subgenus Thysananthus, based on the results of morphological-anatomical, phytochemical and molecular phylogenetic analyses, leads to the recognition of 29 species in the genus: 15 species in subg. Thysananthus in two sections, sect. Thysananthus (eleven species) and sect. Dendrolejeunea (Spruce) Sukkharak (four species) and 14 species in subg. Mastigolejeunea (Spruce) Sukkharak. Based on the morphological-anatomical study two new species, $T$. discretus Sukkharak \& Gradst. and T. combinatus Sukkharak, and one new variety are newly described and several new or little known morphological characters are recognized. The chemical heterogeneity of $T$. convolutus, which is congruent with variation in the dentation of leaves, underleaves and female bracts in this species, supports resurrection of T. gottschei, considered a synonym of $T$. convolutus, as a separate taxon. The results of a molecular phylogenetic analysis confirm the placement of Mastigolejeunea pancheri in Thysananthus and provide evidence for a broader circumscription of the genus Thysananthus, including the genera Dendrolejeunea and Mastigolejeunea. The molecular evidence also supports the status of $T$. gottschei and M. humilis (= T. humilis) as separate species and reveals the existence of a putative hybrid, the first one detected in Lejeuneaceae. A monographic treatment of subg. Thysananthus provides a synthesis of the morphological and chemical variation in the subgenus, and the new classification of the broadly defined genus Thysananthus. Some new taxa are described and numerous new combinations are proposed. An artificial key to the species of the genus Thysananthus is provided and each species of subg. Thysananthus is fully described and illustrated, with extensive synonymy and detailed data on habitat and distribution. An annotated list of the fourteen species in subg. Mastigolejeunea is also provided. The subg. Thysananthus is mainly characterized by Lejeunea-type vegetative branches, stem epidermal cells large as medullary cells or dorsal epidermal cells enlarged, leaves convolute when dry, leaf cells elongate and trigones cordate, adnate underleaves present, gynoecial innovations present and with lejeuneoid leaf sequence, female involucres toothed, and perianth sharply 3-keeled and toothed. The subg. Thysananthus is pantropical in distribution, with four species ranging into warm temperate regions; the centre of diversity is in Southeast Asia. The species grow as epiphytes in tropical lowland and montane rain forests and cloud forests.
\end{abstract}




\section{ZUSAMMENFASSUNG}

Als Ergebnis einer systematischen Bearbeitung der Lebermoosgattung Thysananthus, insbesondere der Untergattung Thysananthus, auf der Basis morphologisch-anatomischer, phytochemischer und molekularphylogenetischer Analysen, werden 29 Arten anerkannt: 15 Arten in der Untergattung Thysananthus in zwei Sektionen, sect. Thysananthus (11 Arten) und sect. Dendrolejeunea (Spruce) Sukkharak (vier Arten), und 14 Arten in der Untergattung Mastigolejeunea (Spruce) Sukkharak. Die morphologisch-anatomischen Untersuchungen führen zur Neubeschreibung zweier Arten, T. discretus Sukkharak \& Gradst. und T. combinatus Sukkharak, sowie einer neuen Varietät, und zur Beschreibung mehrerer neuer oder bislang wenig bekannter morphologischer Merkmale. Die chemische Heterogenität von T. convolutus, die mit Unterschieden in der Zähnung von Blättchen und Unterblättchen übereinstimmt, unterstützt die Wiederanerkennung der Art T. gottschei, welche bislang als synonym mit $T$. convolutus angesehen wurde. Die Ergebnisse der molekularphylogenetischen Analysen bestätigen die Stellung von Mastigolejeunea pancheri in Thysananthus und bieten Anhaltspunkte für eine breitere Umschreibung der Gattung Thysananthus, inklusive der Gattungen Dendrolejeunea und Mastigolejeunea. Die molekularen Daten unterstützen den Status von T. gottschei und M. humilis (= T. humilis) als eigene Arten und weisen auf die Existenz einer möglichen Hybride hin, der ersten die bislang in den Lejeuneaceae gefunden wurde. Die monographische Bearbeitung der Untergattung Thysananthus beinhaltet eine Synthese der morphologischen und chemischen Variabilität in der Untergattung, eine neue taxonomische Einteilung der weit gefassten Gattung Thysananthus mit einigen neuen Taxa und zahreichen neuen Kombinationen, sowie einen Bestimmungsschlüssel der Arten der Gattung Thysananthus. Alle Arten der Untergattung Thysananthus werden ausführlich beschrieben und illustriert, mit detaillierten Angaben $\mathrm{zu}$ Synonymen, Habitaten und Verbreitung. Die 14 Arten der Untergattung Mastigolejeunea werden in einer kommentierten Auflistung behandelt. Die Untergattung Thysananthus kann im Wesentlichen durch die Kombination der folgenden Merkmale charakterisiert werden: Verzweigung der vegetativen Äste vom Lejeunea-Typ, Epidermiszellen der Stämmchen ebenso groß wie die Markzellen oder auf der Dorsalseite vergrößert, Blättchen im trockenen Zustand zusammengerollt, Blattzellen verlängert und mit herzförmigen Eckenverdickungen, verwachsene Unterblättchen vorhanden, gynöziale Erneuerungstriebe vorhanden und mit lejeuneoider Blattfolge, weibliches Involukrum gezähnt sowie Perianth mit drei scharfen Kielen und gezähnt. Die Untergattung Thysananthus ist pantropisch verbreitet mit Südostasien als Diversitätszentrum, 
vier Arten strahlen in warm-gemäßigte Gebiete aus. Die Arten wachsen als Epiphyten in tropischen Tieflands- und Bergregenwäldern sowie Nebelwäldern. 


\section{SYNOPSIS}

This dissertation is the systematic study of the liverwort genus Thysananthus, with a focus on a world-wide revision of subgenus Thysananthus, based on morphologicalanatomical study of the types and other available herbarium materials, as well as using phytochemical and molecular evidence. Each chapter represents a published, accepted or submitted paper in an international peer-reviewed SCI journals or serial, except for Chapter I which is the introduction to Lejeuneaceae, the introduction to Thysananthus and the current state of knowledge of the genus. The general discussion (IB) summarizes results from the chapters II-VI and indicates necessary future work.

\section{IA. INTRODUCTION}

\section{INTRODUCTION TO LEJEUNEACEAE}

Lejeuneaceae, nested within the liverwort order Porellales, are sister to the families Jubulaceae and Frullaniaceae (Ahonen 2004, Heinrichs et al. 2005, He-Nygrén et al. 2006) and are the largest family of liverworts comprising ca. 1200 species in 78 genera (Frey \& Stech 2009, with updates). They grow mostly as epiphytes in moist tropical forests. In rain forests more than three-fourths of the hepatic species are Lejeuneaceae (Gradstein 1994, 2006) and in montane forests 15-30\% (Gradstein 1994). According to molecular dating (Wilson et al. 2007b, but see Yang \& Wu 2010), diversification started in the Mid-Cretaceous and took place in the shadow of angiosperm evolution, as has also been shown for other lineages of extant cryptogamic plants such as Lycopodiaceae (Wikström et al. 2001) and ferns (Schneider et al. 2004). Morphological characteristics of Lejeuneaceae are incubous leaves with a small ventral lobule attached along a keel, the existence of underleaves and/or rhizoid tufts and the presence of one archegonium per perianth. Several conflicting classifications have been proposed for the family due to the high degree of morphological homoplasy and the lack of stable morphological diagnostic characters to delimit generic and infrageneric groups (Gradstein et al. 2003, Wilson et al. 2007a). Traditionally, on the basis of gametophyte characters, Lejeuneaceae was divided into two artificial groups: "Holostipae" and "Schizostipae", based on underleaf morphology (undivided resp. bifid) and stem anatomy (robust and 10 or more rows of cortical cells resp. thinner and has only 7 rows of cortical cells) (Spruce 1884, Evans 1935, Schuster 1955).

Mizutani (1961) studied Japanese Lejeuneaceae and found that several sporophytic characters including the structure of the seta, the capsule-wall thickenings, and the elaters could be used to separate Holostipae and Schizostipae. He subsequently treated these two 
groups as two subfamilies: Ptychanthoideae Mizut. (= Holostipae) and Lejeuneoideae Massal. (fide Gradstein 1975) (= Schizostipae). Later, several smaller subfamilies and tribes were established by Schuster (1963) and Gradstein (1975, 1994). Recent morphological and molecular phylogenetic analyses (Ahonen et al. 2003, Gradstein et al. 2003, Groth-Malonek et al. 2004, Wilson et al. 2004, 2007a, Heinrichs et al. 2005) supported the division of Lejeuneaceae into two broad subfamilies Ptychanthoideae and Lejeuneoideae. In addition, Wilson et al. (2007a) found molecular evidence for two further, smaller lineages in the family.

\section{INTRODUCTION TO THYSANANTHUS}

Thysananthus Lindenb. is a member of the family Lejeuneaceae subfamily Ptychanthoideae (Mizutani 1961, Gradstein 1975, 1994) and was first described by Lindenberg in 1844 for species with a 3-keeled, toothed perianth containing only one archegonium and being subtended by innovation. Spruce (1884) published the subgenus Thysano-Lejeunea, which was more or less equivalent to Thysananthus, as one of his 37 subgenera of a broadly defined genus Lejeunea Lib. (which was almost equivalent to the present family Lejeuneaceae). The subgenus Thysano-Lejeunea was classified in the "Holostipae" due to its undivided underleaves. Thysananthus had been restored at generic rank again by Schiffner (1893).

The genus Thysananthus as traditionally circumscribed contains about ten species and occurs mainly in tropical Asia (Gradstein 1994). One species, T. spathulistipus (Reinw. et al.) Lindenb., extends from tropical Asia to tropical Africa and T. amazonicus (Spruce) Schiffn. is the only species of the genus occurring in the New World tropics. The species grow as epiphytes in moist tropical forests, from sea level to the tree line.

Spruce and Schiffner, and all later authors, agreed that Thysananthus is morphologically very similar to the genus Mastigolejeunea (Spruce) Schiffn. (14 species) and some authors have even suggested that the two genera might be combined in one genus (Schuster 1980, Gradstein 1985). The two genera differ mainly by the entire perianth and enlarged dorsal epidermis cells. However, these differences are not sharp, as is discussed in Chapters V and VI.

Thysananthus is morphologically heterogeneous (Gradstein 1992) and the taxonomic significance of several characters considered diagnostic of the genus is unclear. As a result, different generic circumscriptions and intrageneric classifications have been evoked. For example, Verdoorn (1934) classified the Asiatic species of Thysananthus into three sections on the basis of leaf characters: (1) T. sect. Spathulistipae Verd. with six species characterized 
by symmetric and rather plane leaves without vitta; (2) $T$. sect. Convolutae Verd. with two species characterized by asymmetric and deeply concave leaves without vitta; and (3) $T$. sect. Vittatae Verd. with three species characterized by symmetric, vittate leaves. Thiers and Gradstein (1989) classified the species from Australia into two subgenera: subg. Thysananthus and subg. Sandeanthus B. Thiers \& Gradst., based on differences in leaf position and areolation. Gradstein (1992) placed the neotropical T. evansii Fulford and T. pterobryoides (Spruce) Schiffn. in the new genus Fulfordianthus Gradst., based on the dendroid habit, the isodiametric leaf cells with evenly thickend walls, lacking any trace of trigones, the lack of oil bodies, etc. Moreover, the genus Dendrolejeunea (Spruce) Lacout. was reinstated for the Asiatic T. fruticosus (Lindenb. \& Gottsche) Schiffn., also based on the dendroid habit. The remaining species of Thysananthus were attributed to the two subgenera recognized by Thiers and Gradstein (1989).

In the papers of Chapters II-V the genus Thysananthus is circumscribed in the traditional narrow sense, maintaining Dendrolejeunea and Mastigolejeunea as separate general. In Chapter VI, however, Dendrolejeunea and Mastigolejeunea are united with Thysananthus based on the results of molecular analysis. As a consequence, Thysananthus is treated in a much wider sense in the final chapter of this study.

\section{MORPHOLOGICAL AND ANATOMICAL STUDY}

Thysananthus was first described based essentially on the sharply 3-keeled, dentatelaciniate perianth (Lindenberg 1844). Further differential characters have been added by later authors, viz. toothed leaves (Spruce 1884), elongate leaf cells (Stephani 1912), possession of purely existence of Lejeunea-type branches, leaves convolute when dry, epidermal cells as large as medullary cells and trigones cordate, often become coalesced, (Gradstein 1975), and lejeuneoid leaf sequence of innovations (Thiers \& Gradstein 1989).

Mizutani (1969, 1977), Kitagawa (1973) and Mizutani and Piippo (1986) have paid attention to the occurrence of connate leaves and underleaves in Thysananthus, but the taxonomic relevance of this feature has remained controversial. The study of more than 1600 herbarium materials from various museums and herbaria worldwide as well as fresh specimens of Thysananthus resulted in a better understanding of the morphological and anatomical characters in the genus, especially the connate leaves and underleaves and appendages on the keel of leaves, bracts and perianths. In addition, not only the appendage which is attached to the lobule bases and the stem epidermis cells on both sides of the stem was newly observed but also $T$. discretus Sukkharak \& Gradst., was newly described based on 
hitherto neglected morphological characters of the underleaves. Thysananthus discretus is described and illustrated in Chapter II and Chapter III deals with some new or little known morphological characters.

\section{CHEMICAL STUDY}

Liverworts are able to synthesize large quantities of terpenoids, especially sesquiterpenoids, diterpenoids, and lipophilic aromatic compounds, which are stored in oil bodies (e.g., Gradstein et al. 1985). These substances, especially terpenoids, often show strong biological activity and may play an important role in the defence of the plants against environmental hazards (Gradstein 1994) or predators (Harinantenaina et al. 2006). Several studies have been conducted on the terpenoids and aromatic compounds of the members of Ptychanthoideae (e.g., Asakawa 1982, 1995, 2004, Asakawa et al. 1980a, 1980b, Gradstein et al. 1981, 1985, 1988, Kruijt et al. 1986, Harinantenaina et al. 2006).

Seven species of Thysananthus: T. amazonicus, T. appendiculatus Steph., T. convolutus Lindenb., T. discretus (under T. convolutus sample nr. 49 in Gradstein et al. 1985), T. mollis Steph., T. retusus (Reinw. et al.) B. Thiers \& Gradst. (under T. fruticosus in Gradstein et al. 1985) and T. spathulistipus, have been investigated for the occurrence of terpenoids, flavonoids, sterols, and aromatic compounds. The results showed that most species elaborate large amounts of sesquiterpenoids and unidentified diterpenoids. At least six different flavonoids are detected in T. appendiculatus. Stigmasterol is reported from all these species. No trace of aromatic compounds can be detected in studied species except in $T$. appendiculatus (Gradstein et al. 1985, Kruijt et al. 1986, Harinantenaina et al. 2006).

Fresh material of four species of Thysananthus: T. comosus Lindenb., T. convolutus, $T$. retusus, T. spathulistipus, and Dendrolejeunea fruticosa (Lindenb. \& Gottsche) Lacout. from Thailand and Malaysia, enabled chemical study. Chapter IV deals with the terpenoid chemistry of these materials.

\section{PHYLOGENETIC STUDY}

Gradstein (1994), in his revision of neotropical Ptychantheae and Brachiolejeuneae, included a cladistic analysis of the these two tribes of Lejeuneaceae using 26 morphological characters. Later, a comprehensive phylogenetic investigation of generic relationships within the Lejeuneaceae using 67 morphological characters and one chemical character in 69 genera was published by Weis (2001). She recognized three subfamilies: Nipponolejeuneoideae (genus Nipponolejeunea only; basal clade), Ptychanthoideae and Lejeuneoideae. The first 
molecular phylogenetic analysis of 12 genera of Lejeuneaceae using three markers (plastid $r b c L, \operatorname{trnL}-F, \operatorname{nrITS} 2)$ was conducted by Ahonen et al. (2003). In addition, Gradstein et al. (2003) published a morphological phylogenetic analysis and classification of 69 genera of Lejeuneaceae. The division of Lejeuneaceae into the subfamilies Ptychanthoideae and Lejeuneoideae was supported by their analyses as well as later authors (Groth-Malonek et al. 2004, Wilson et al. 2004, 2007a, Heinrichs et al. 2005).

Morphological phylogenetic analysis of the Ptychanthoideae (Gradstein 1994, Gradstein et al. 2003) recovered Thysananthus as a member of the Ptychanthinae clade together with Bryopteris (Nees) Lindenb., Mastigolejeunea, Ptychanthus Nees and Schiffneriolejeunea Verd. However, Dendrolejeunea was not included in the analysis because sporophytes were unknown. Wilson et al. (2007a) in a molecular phylogenetic analysis of the family based on four markers (plastid $r b c L, p s b A, \operatorname{trn} L-F$, nrITS) recovered Thysananthus (4 species sampled) in a robust clade together with Dendrolejeunea and Mastigolejeunea, being sister to a clade containing Ptychanthus and Spruceanthus Verd. Bryopteris and Schiffneriolejeunea appeared to be more distantly related to Thysananthus. All studies revealed Thysananthus as monophyletic.

Phylogenetic inference of Lejeuneaceae is often hampered by meagre taxon and/or marker sampling (Wilson et al. 2007a). In Chapter V, however, samples of all currently recognized species of Thysananthus, covering almost the entire range of morphological variation within the genus, and from a representative species set of related genera, have been used to generate DNA sequence information. The molecular data from five markers (plastid psbA-trnH, trnG, trnL-F, trnS-rps4, nrITS), morphological characters of all molecularly analyzed specimens as well as phytochemical (terpenoid) data from selected Thysananthus species and Dendrolejeunea fruticosa were analyzed comparatively in a phylogenetic framework for the first time in Lejeuneaceae.

\section{MONOGRAPH OF THYSANANTHUS SUBGENUS THYSANANTHUS}

The taxonomic revision of Asiatic Thysananthus by Verdoorn (1934) marks the beginning of modern research in the genus. Several regional revisions of Thysananthus have been undertaken later (e.g., Fulford 1941, Vanden Berghen 1950, Thiers \& Gradstein 1989, Gradstein 1992, 1994). However, Gradstein (1985) and Thiers and Gradstein (1989) noted that Thysananthus is in need of revision on a world-wide basis. Based on the molecular results in Chapter V, Dendrolejeunea is returned to Thysananthus in Chapter VI and Mastigolejeunea (fourteen spp.) is combined with Thysananthus, as T. subg. Mastigolejeunea (Spruce) 
Sukkharak. In Chapter VI, a world-wide revision of subg. Thysananthus leads to the recognition of fifteen species in this subgenus, in two sections: sect. Thysananthus (eleven species) and sect. Dendrolejeunea (Spruce) Sukkharak (four species). The two sections are characterized by the absence resp. presence of a vitta in the leaves. One species, T. combinatus Sukkharak and one variety are newly described, and numerous new combinations are proposed. An artificial key to the species of the genus Thysananthus is provided and each species of subg. Thysananthus is fully described and illustrated, with extensive synonymy and detailed data on habitat and distribution. An annotated list of the species in subg. Mastigolejeunea is also provided.

\section{IB. GENERAL DISCUSSION}

A study of a large series of specimens of all species of subg. Thysananthus leads to the recognition of new species, Thysananthus discretus, in Chapter II and a better understanding of new or little known morphological characters in Chapter III. Thysananthus discretus is described from Western Melanesia (New Guinea, Solomon Islands). The new species stands out within Thysananthus on account of the leaves when moist clasping the stem, free underleaf bases with the well-developed auricles, and the strongly rigid stems with 14-18 cells wide ventral merophytes. Free underleaf bases, which are not connate with the leaves, is an unusual character in Thysananthus and occur otherwise in the New Guinean endemics $T$. mollis and T. montanus Gradst. et al., and occasionally in the widespread T. retusus. Whereas, the presence of adnate underleaves that are connected to leaf bases appears to be a stable and taxonomically relevant feature of $T$. aculeatus Herzog, T. amazonicus, T. appendiculatus, $T$. comosus, T. convolutus, T. laceratus Steph. (= T. convolutus var. laceratus (Steph.) Sukkharak) and T. spathulistipus. Interestingly, the adnation of underleaves on branches occurs in a distinct left-right symmetry pattern, on right-hand branches being connected to leaves on the left side and on left-hand branches on the right-hand side. The further morphological feature, relative to leaf bases, is a small "appendage" that may be developed on leaves, female bracts and perianths. In T. appendiculatus, $T$. discretus and $T$. laceratus the appendages are found on the keel of leaves and inserted partially on the stems. In all Thysananthus species wing-like appendages may be occur on the keels of the female bracts, on one or both sides of the stem. In addition, a small appendage may be found on the midbasal portion of the bract lobules and on the base of the keels of the perianth. Moreover, an appendage which is attached to the lobule bases and the stem epidermis cells on both sides of the stem was newly observed in T. mollis, T. montanus and T. retusus. 
Noteworthy of the results of chemical analysis dealing with the terpenoid in Chapter IV is the chemical heterogeneity of Thysananthus convolutus, which is congruent with variation of the dentation of leaves, underleaves and female bracts in this species. The edentate form has been called T. gottschei (Jack \& Steph.) Steph., which was reduced to a synonym of $T$. convolutus (Grolle \& Piippo, 1984). The results in Chapter IV suggest that T. gottschei may have to be resurrected as a separate taxon. In addition, chemical composition of Dendrolejeunea fruticosa detected in this study is very different from Thysananthus species. In other instances, however, the chemical findings do not coincide with morphology. For instance, unidentified compound $\left(\mathrm{M}^{+}\right) 302,190(100)$, 81(95) was detected in T. convolutus and in one sample of $T$. comosus, and the unidentified $\left(\mathrm{M}^{+}\right) 320,207(100), 81(83)$ in $T$. spathulistipus sample 2 and Malaysian T. convolutus but not in other samples of these species. Furthermore, pinguisane sesquiterpenoids were only found in the morphologically very different species $T$. retusus and $T$. spathulistipus.

Phylogenetic analyses in Chapter $\mathrm{V}$ have provided us a better understanding into the systematic relationships and diversification pattern within Thysananthus. The species of Thysananthus are resolved into two major clades, which also include Dendrolejeunea fruticosa and Mastigolejeunea pancheri Steph. The clade of D. fruticosa, T. mollis, T. montanus and T. retusus stands out by the presence of vitta and corresponds to a section recognized in early classifications. The well-supported sister relationship between the $T$. anguiformis (Hook. f. \& Taylor) Steph.-M. pancheri and Thysananthus s. str. clades is noteworthy as $M$. pancheri has long been separated from Thysananthus by its entire female involucres and presence of a stem hyalodermis. Within Thysananthus s. str., T. comosus, T. convolutus and $T$. spathulistipus were polyphyletic, but the molecular clades largely fit with formerly recognized but later synonymised species, $T$. gottschei, and in one case with a novel species that is also recognizable morphologically. Incongruence between plastid and ITS data in $M$. pancheri indicated the occurrence of a putative hybrid, the first one recorded in Lejeuneaceae and the first in liverworts inferred from phylogenetic data. Interestingly, the molecular evidence of Wilson et al. (2007a) and the present study suggests that the Asiatic and neotropical populations of $M$. auriculata (Wils.) Schiffn. represent different taxa. The plants from Asia and Neotropics are also morphologically different. The Asian populations of M. auriculata were originally described as M. humilis (Gottsche) Schiffn.; later taxonomic work (e.g., Gradstein \& Inoue 1980, Gradstein 1994) suggested that M. humilis cannot be sharply separated morphologically from $M$. auriculata, described from the Neotropics. The 
molecular results in Chapter $\mathrm{V}$, however, clearly support the recognition of the Asiatic $M$. humilis as a separate species.

Based on the results of morphological-anatomical, phytochemical and molecular phylogenetic analyses, the genus Thysananthus is divided in Chapter VI into 2 subgenera: subg. Thysananthus (15 spp., 4 varieties, 2 subspecies) and subg. Mastigolejunea (14 spp.). The classification of Thysananthus in Chapter VI is as follows:

Thysananthus subg. Thysananthus

sect. Thysananthus

ser. Thysananthus

1. T. aculeatus Herzog

2. T. amazonicus (Spruce) Schiffn.

3. T. appendiculatus Steph.

4. T. combinatus Sukkharak

5. T. comosus Lindenb.

6. T. convolutus Lindenb.

var. convolutus

var. laceratus (Steph.) Sukkharak

7. T. discretus Sukkharak \& Gradst.

8. T. gottschei (Jack \& Steph.) Steph.

var. gottschei

var. continuus Sukkharak

9. T. spathulistipus (Reinw. et al.) Lindenb.

ser. Anguiformes Sukkharak

10. T. anguiformis (Hook. f. \& Taylor) Steph.

11. T. pancheri (Steph.) Hürl.

sect. Dendrolejeunea (Spruce) Sukkharak

ser. Dendrolejeunea

12. T. fruticosus (Lindenb. \& Gottsche) Schiffn.

ser. Sandeanthus (B. Thiers \& Gradst.) Sukkharak

13. T. mollis Steph.

14. T. montanus Gradst. et al.

15. T. retusus (Reinw. et al.) B. Thiers \& Gradst.

subsp. retusus 
subsp. sellingii (Hürl.) Sukkharak

Thysananthus subg. Mastigolejeunea (Spruce) Sukkharak

16. T. auriculatus (Wils.) Sukkharak

17. T. calcaratus (Steph.) Sukkharak

18. T. floreus (Mitt.) Sukkharak

19. T. humilis (Gottsche) Sukkharak

20. T. integrifolius Steph.

21. T. innovans (Spruce) Sukkharak

22. T. ligulatus (Lehm. \& Lindenb.) Sukkharak

23. T. plicatiflorus (Spruce) Sukkharak

24. T. reconditus (Steph.) Sukkharak

25. T. recurvifolius (Mizut.) Sukkharak

26. T. repletus (Taylor) Sukkharak

27. T. truncatus (Mizut.) Sukkharak

28. T. undulatus (Gradst. \& Grolle) Sukkharak

29. T. virens Ångstr.

In its current circumscription, subg. Thysananthus is mainly characterized by Lejeunea-type vegetative branches, (2) stem epidermal cells large as medullary cells (dorsal epidermal cells enlarged in T. combinatus, T. anguiformis, T. pancheri), (3) leaves convolute when dry (spread out widely in T. retusus), (4) Leaf cells elongate and trigones cordate (isodiametric and trigones faint in T. retusus), (5) adnate underleaves present (absent in $T$. discretus, T. fruticosus, T. mollis, T. montanus), (6) gynoecial innovations present and with lejeuneoid leaf sequence, (7) female involucres toothed (entire in T. anguiformis, T. pancheri), and (8) perianth sharply 3-keeled and toothed (entire in T. montanus).

\section{FUTURE PROSPECTS}

The chemotaxonomic conclusions presented in Chapter IV are still preliminary. The results obtained in the study will be substantiated by isolation and identification of the detected unidentified compounds, which is in progress (Ludwiczuk, in prep.).

Molecular phylogenetic results presented in Chapter $\mathrm{V}$ revealed that Thysananthus comosus, $T$. convolutus (as traditionally circumscribed) and $T$. spathulistipus are polyphyletic. Increased taxon sampling is needed to clarify the relationships of these taxa. Incongruence between plastid and ITS data in one sample of $M$. pancheri led to the first report of a putative 
hybrid in Lejeuneaceae, and the first one in liverworts inferred from phylogenetic data. However, inference from a more detailed dated phylogeny of Ptychanthoideae may confirm the putative young age of the hybridization event. Further analyses including chromosome counts may determine a possible polyploidy of the hybrid.

Finally, the fourteen species currently accepted in Mastigolejeunea are transferred to Thysananthus in Chapter VI but are only briefly listed in the recent monograph. A full treatment of the subg. Mastigolejeunea should be the subject of future work.

\section{REFERENCES}

Ahonen, I. 2004. Molecular phylogeny of the liverwort order Porellales (Marchantiophyta, Jungermanniopsida). Monogr. Syst. Bot. Missouri Bot. Gard. 98: 168-188.

Ahonen, I., Muona, J. \& Piippo, S. 2003. Inferring the phylogeny of the Lejeuneaceae (Jungermanniopsida): a first appraisal of molecular data. Bryologist 106: 297-308.

Asakawa, Y. 1982. Chemical constituents of the Hepaticae. In: Progress in the Chemistry of Organic Natural Products, 42. (eds. W. Herz, H. Grisebach \& G.W. Kirby), pp. 1-285. Vienna: Springer.

Asakawa, Y. 1995. Chemical constituents of the Bryophytes. In: Progress in the Chemistry of Organic Natural Products, 65. (eds. W. Herz, G.W. Kirby, R.E. Moore, W. Steglich \& C. Tamm.), pp. 1-618. Vienna: Springer.

Asakawa, Y. 2004. Chemosystematics of the Hepaticae. Phytochemistry 65: 623-669.

Asakawa, Y., Tokunaga, N., Takemoto, T., Hattori, S., Mizutani, M. \& Suire, C. 1980a. Chemosystematics of Bryophytes IV. J. Hattori Bot. Lab. 47: 153-164.

Asakawa, Y., Suire, C., Toyota, M., Tokunaga, N., Takemoto, T., Hattori, S. \& Mizutani, M. 1980b. Chemosystematics of Bryophytes V. J. Hattori Bot. Lab. 48: 285-303.

Evans, A.W. 1935. The anatomy of the stem in the Lejeuneaceae. Bull. Torrey Bot. Club 62: 187-214, 259-280.

Fulford, M.H. 1941. Studies on American Hepaticae I. Revision of the genus Thysananthus. Bull. Torrey Bot. Club 68: 32-42.

Frey, W. \& Stech, M. 2009. Marchantiophyta, Bryophyta, Anthocerotophyta. In: Syllabus of plant families. A. Engler's Syllabus der Pflanzenfamilien, 13th ed., part 3, Bryophytes and seedless vascular plants. (ed. W. Frey), pp. 13-263. Stuttgart: Schweizerbart.

Gradstein, S.R. 1975. A taxonomic monograph of the genus Acrolejeunea (Hepaticae) with an arrangement of the genera of Ptychanthoideae. Bryophyt. Biblioth. 4: 1-162. 
Gradstein, S.R. 1985. A guide to the Holostipous Lejeuneae. In: Contributions to a monograph of the Lejeuneaceae subfamily Ptychanthoideae, ed. S.R. Gradstein. Beih. Nova Hedwigia 80: 13-29.

Gradstein, S.R. 1992. The genera Thysananthus, Dendrolejeunea, and Fulfordianthus gen. nov. (Studies on Lejeuneaceae Subfamily Ptychanthoideae XXI). Bryologist 95: 42-51.

Gradstein, S.R. 1994. Lejeuneaceae: Ptychantheae, Brachiolejeuneae. Fl. Neotrop. Monogr. 62: 1-216.

Gradstein, S.R. 2006. The lowland cloud forest of French Guiana-a liverwort hotspot. Cryptog. Bryol. 27: 141-152.

Gradstein, S.R. \& Inoue, H. 1980. Studies on Lejeuneaceae subfam. Ptychanthoideae, V. A review of the species from Ceylon. Bull. Nat. Sci. Mus. Tokyo, ser. B. 6: 23-32.

Gradstein, S.R., Matsuda, R. \& Asakawa, Y. 1981. Oil bodies and terpenoids in Lejeuneacae and other selected Hepaticae. J. Hattori Bot. Lab. 50: 232-248.

Gradstein, S.R., Matsuda, R. \& Asakawa, Y. 1985. A chemotaxonomic survey of terpenoids and aromatic compounds in the Lejeuneaceae (Hepaticae). Beih. Nova Hedwigia 80: 63-86.

Gradstein, S.R., Asakawa, Y., Mues, R. \& Klein, R. 1988. On the taxonomic significance of secondary metabolites in the Lejeuneaceae (Hepaticae). J. Hattori Bot. Lab. 64: 159168.

Gradstein, S.R., Reiner-Drehwald, M.E. \& Schneider, H. 2003. A phylogenetic analysis of the genera of Lejeuneaceae (Hepaticae). Bot. J. Linn. Soc. 143: 391-410.

Grolle, R. \& Piippo, S. 1984. Annotated catalogue of Western Melanesian bryophytes. I Hepaticae and Anthocerotae. Acta Bot. Fenn. 125: 1-86.

Groth-Malonek, M., Heinrichs, J., Schneider, H. \& Gradstein, S.R. 2004. Phylogenetic relationships in the Lejeuneaceae (Hepaticae) inferred using ITS sequences of nuclear ribosomal DNA. Organisms Diversity Evol. 4: 51-57.

Harinantenaina, L., Takahara, Y., Nishizawa, T., Kohchi, C., Soma, G.-I. \& Asakawa, Y. 2006. Chemical constituents of Malagasy liverwort, part V: prenyl bibenzyls and clerodane diterpenoids with nitric oxide inhibitory activity from Radula appressa and Thysananthus spathulistipus. Chem. Pharm. Bull. 54: 1046-1049.

Heinrichs, J., Gradstein, S.R., Wilson, R. \& Schneider, H. 2005. Towards a natural classification of liverworts (Marchantiophyta) based on the chloroplast gene $r b c L$. Cryptog. Bryol. 26: 131-150. 
He-Nygrén, X., Juslén, A., Ahonen, I., Glenny, D. \& Piippo, S. 2006. Illuminating the evolutionsary history of liverworts (Marchantiophyta) - towards a natural classifiacirton. Cladistics 22: 1-31.

Kitagawa, N. 1973. Miscellaneous notes on little-known species of Hepaticae, 26-50. J. Hattori Bot. Lab. 37: 263-273.

Kruijt, R.C., Niemann, G.J., de Koster, C.G. \& Heerma, W. 1986. Flavonoids and aromatic hydroxy acids in Lejeuneaceae subfamily Ptychanthoideae (Hepaticae). Cryptog. Bryol. Lichénol. 7: 165-171.

Lindenberg, J.B.W. 1884. Synopsis Hepaticarum. In: Nov. Stirp. Pug 8 (ed. J.G.G. Lehmann), pp. 1-56. Hamburgi: Meissnerianis.

Mizutani, M. 1961. A revision of Japanese Lejeuneaceae. J. Hattori Bot. Lab. 24: 115-302.

Mizutani, M. 1969. Lejeuneaceae Subfamily Ptychanthoideae from Sabah (North Borneo). J. Hattori Bot. Lab. 32: 129-139.

Mizutani, M. 1977. Lejeuneaceae from Philippines. J. Hattori Bot. Lab. 43: 127-136.

Mizutani, M. \& Piippo, S. 1986. Some species of Lejeuneaceae from New Guinea. J. Hattori Bot. Lab. 61: 477-485.

Schiffner, V. 1893. Hepaticae (Lebermoose). In: Die Natürlichen Pflanzenfamilien (eds. A. Engler \& K. Prantl), pp. 1-141. Leipzig: Wilhelm Engelmann.

Schuster, R.M. 1955. North American Lejeuneaceae. I. Introduction; keys to subfamilies and genera. J. Elisha Mitchell Sci. Soc. 71: 106-126.

Schuster, R.M. 1963. An annotated synopsis of the genera and subgenera of Lejeuneaceae, I. Introduction; annotated keys to subfamilies and genera. Beih. Nova Hedwigia 9: 1-203.

Schuster, R.M. 1980. The Hepaticae and Anthocerotae of North America, vol. 4. New York: Columbia University Press.

Schneider, H., Schuettpelz, E., Pryer, K.M., Cranfill, R., Magallon, S. \& Lupia, R. 2004. Ferns diversified in the shadow of angiosperms. Nature 428: 553-557.

Spruce, R. 1884. Hepaticae of the Amazon and of the Andes of Peru and Ecuador. III Lejeunea Libert. Trans. Proc. Bot. Soc. Edinburgh 15: 63-305.

Stephani, F. 1909-1912. Species Hepaticarum. IV. Genève et Bale, Lyon.

Thiers, B.M. \& Gradstein, S.R. 1989. Lejeuneaceae (Hepaticae) of Australia. I. Subfamily Ptychanthoideae. Mem. New York Bot. Gard. 52: 1-79.

Vanden Berghen, C. 1950. Le genre Thysananthus Lindenb. en Afrique. Rev. Bryol. Linchénol. 19: 35-37. 
Verdoorn, F. 1934. Studien über Asiatische Jubuleae (De Frullaniaceis XV-XVII) mit einer Einleitung, Bryologie und Hepaticologie, Ihre Methodik und Zukunft. Ann. Bryol., Suppl. 4: 1-231.

Weis, G. 2001. Morphologische un anatomische Untersuchungen der Sporophyten bei den Jubulaceae Klinggr. und Ljeuneaceae Casares-Gil (Hepaticae) und deren systematische Bedeutung. Bryophyt. Biblioth. 57: 1-307.

Wikström, N. \& Kenrick, P. 2001. Evolution of the Lycopodiaceae (Lycopsida): Estimating divergence times from $r b c L$ gene sequences by use of nonparametric rate smoothing. Molec. Phylog. Evol. 19: 177-186.

Wilson, R., Gradstein, S.R., Heinrichs, J., Groth, H., Ilkiu Borges, A.L. \& Hartmann, F.A. 2004. Phylogeny of Lejeuneaceae: a cladistic analysis of chloroplast gene $r b c L$ sequences and morphology with preliminary comments on the mitochondrial nad4-2 spacer region. Monogr. Syst. Bot. Missouri Bot. Grad. 98: 189-202.

Wilson, R., Gradstein, S.R., Schneider, H. \& Heinrichs, J. 2007a. Unravelling the phylogeny of Lejeuneaceae (Jungermanniopsida). Molec. Phylog. Evol. 43: 270-282.

Wilson, R., Heinrichs, J., Hentschel, J., Gradstein, S.R. \& Schneider, H. 2007b. Steady diversification of derived liverworts under Tertiary climatic fluctuations. Biol. Lett. 3: 566-569.

Yang, X.J. \& Wu, X.W. 2010. Sinolejeunea yimaensis gen. et sp. nov. (Hepaticae) from the Middle Jurassic Yima Formation in Henan Province of China. Sci. China Earth Sci. 54: 228-232. DOI: 10.1007/s11430-010-4153-2. 


\title{
Studies on the genus Thysananthus (Marchantiophyta: Lejeuneaceae) 1. Thysananthus discretus Sukkharak et Gradst. sp. nov.
}

\author{
Phiangphak SUKKHARAK ${ }^{*} \&$ Robbert GRADSTEIN \\ Department of Systematic Botany, Albrecht von Haller Institute of Plant Sciences, \\ University of Göttingen, Untere Karspüle 2, 37073 Göttingen, Germany
}

(Received 10 November 2009, accepted 5 January 2010)

\begin{abstract}
The liverwort, Thysananthus discretus Sukkharak et Gradst. sp. nov. (Lejeuneaceae) is described from Western Melanesia (New Guinea, Solomon Islands). The new species stands out within Thysananthus on account of the leaves when moist clasping the stem, free underleaf bases with the well-developed auricles, and the strongly rigid stems with 14-18 cells wide ventral merophytes.
\end{abstract}

Lejeuneaceae / liverworts / morphology / taxonomy / Thysananthus discretus / Western Melanesia

\section{INTRODUCTION}

Thysananthus Lindenb. is a member of Lejeuneaceae subfamily Ptychanthoideae Mizut. (Mizutani, 1961; Gradstein, 1975) and probably contains about ten species, growing as epiphytes in rain forests and montane cloud forests throughout the tropics. The centre of diversity of the genus is in Southeast Asia with eight species occurring in the area (T. aculeatus Herzog, T. appendiculatus Steph., T. comosus Lindenb., T. convolutus Lindenb., T. mollis Steph., T. montanus Gradst. et al., T. retusus (Reinw. et al.) B. Thiers et Gradst. and T. spathulistipus (Reinw. et al.) Lindenb.). One species is known from the New World tropics (T. amazonicus (Spruce) Schiffn.).

In the course of a world-wide revision of Thysananthus we found that some collections from New Guinea and Solomon Islands represent a hitherto undescribed taxon. The new species, Thysananthus discretus Sukkharak et Gradst., is described and illustrated in this paper. In addition a key to the species is provided.

\section{SYSTEMATIC TREATMENT}

Thysananthus discretus Sukkharak et Gradst., sp. nov.

Figs 1-21

Type. Indonesia, Papua ["Netherlands New Guinea, distr. Hollandia"], Cycloop Mountains, path Ifar-Ormoe, alt. 1220 m, 21 Aug 1961, Royen \& Sleumer 5896 (holotype, L; isotypes, JE, S). The epithet discretus refers to the free underleaf bases, which are not connate with the leaves.

* Correspondence and reprints: ppsukk@gmail.com 


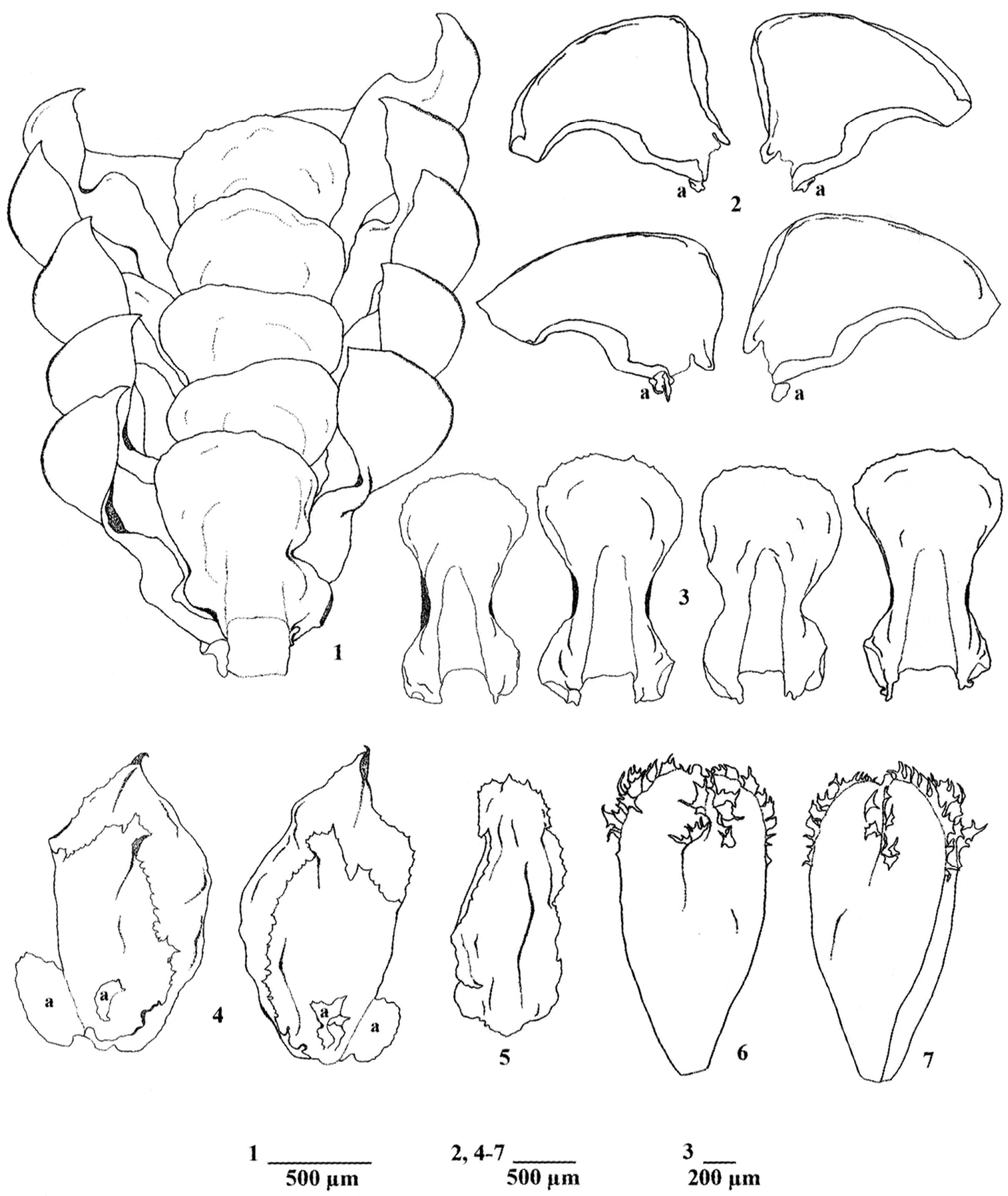

Figs 1-7. Thysananthus discretus Sukkharak et Gradst. 1. Portion of shoot, ventral view. 2. Leaves, ventral view. 3. Underleaves. 4. Female bracts. 5. Female bracteole. 6. Perianth, dorsal view. 7. Perianth, ventral view. (1-3 from the holotype; 4-7 from Royen \& Sleumer 5907 [L]). $\mathrm{a}=$ appendage.

Caulis rigida, 14-18 cellulis lata ventralibus. Folia asymmetrica rotundata. Amphigastria libera, ad basim auriculata.

Plants with vigorous shoots, yellowish brown in herbarium specimens, up to $6.5 \mathrm{~cm}$ long $\times 2-3 \mathrm{~mm}$ wide, habit deliquescent with projecting growth, turning upwards and becoming ascending to erect, irregularly (1)-pinnate, branches Lejeunea-type. Stems strongly rigid; ventral merophyte 14-18 cells wide; in cross 

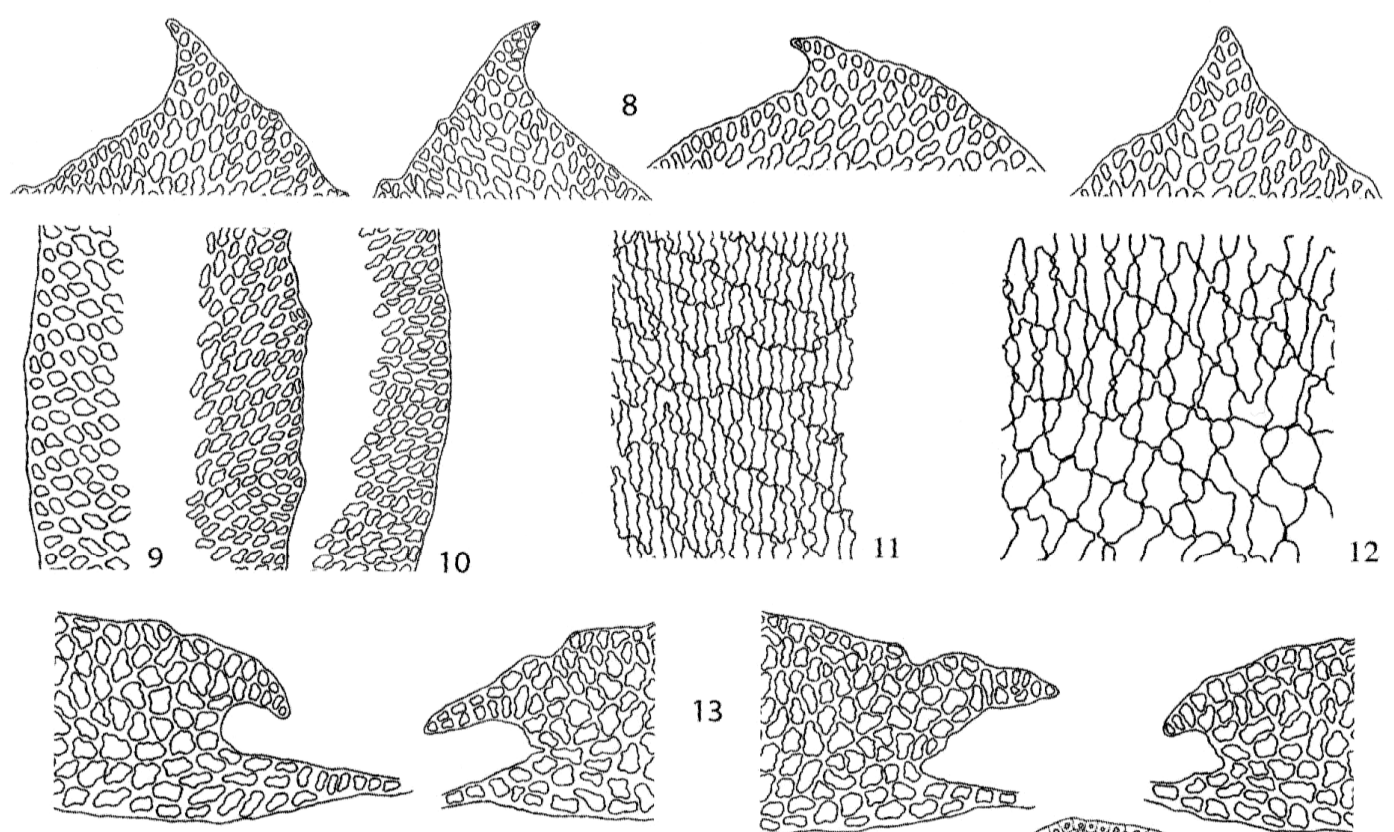

13
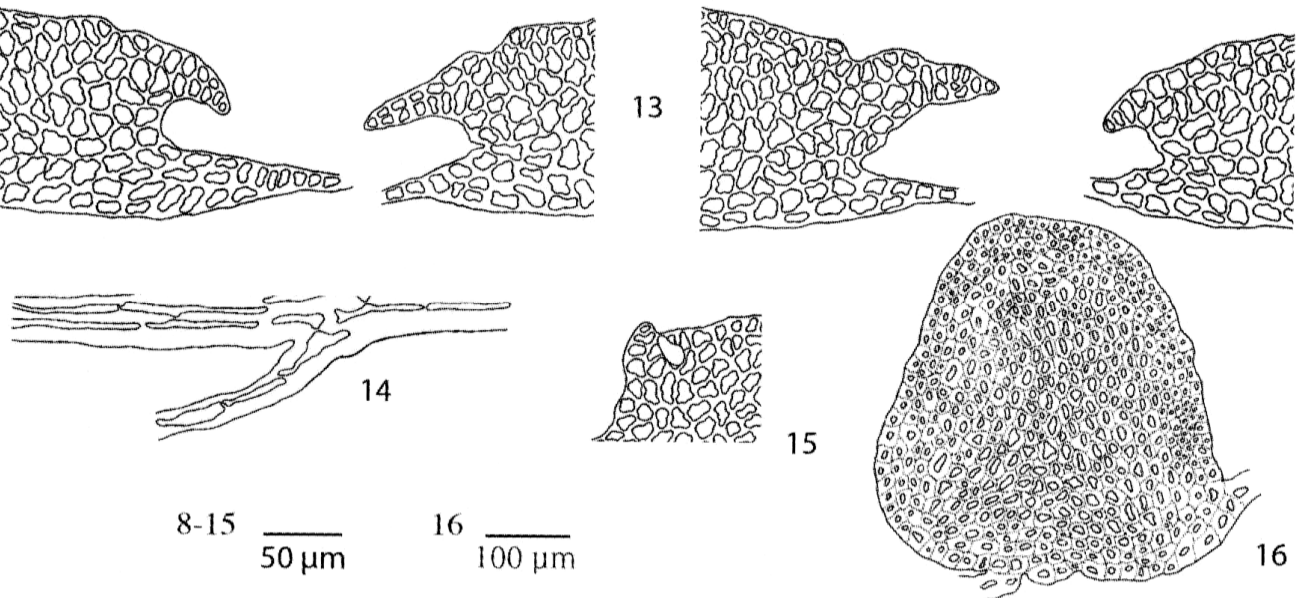

15

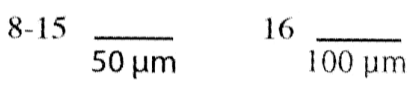

Figs 8-16. Thysananthus discretus Sukkharak et Gradst. 8. Leaf apices. 9. Dorsal margin cells of leaf lobe. 10. Ventral margin cells of leaf lobe. 11. Median cells of leaf lobe. 12. Basal cells of leaf lobe. 13. Leaf lobule apices. 14. Underleaf base in longitudinal section. 15. Inner surface of lobule apex showing hyaline papilla. 16. Cross section of stem. (All from the holotype).

section orbicular-subelliptic in shape, 360-500 $\mu \mathrm{m}$ high $\times 260-445 \mu \mathrm{m}$ wide, composed of 76-80 epidermal cells surrounding 365-381 medullary cells in 1622 layers, epidermal cells not larger than medullary cells, all cells with thickened walls, walls of epidermal cells brownish, those of medullary cells hyaline. Leaves imbricate, when dry suberect and strongly convolute, when moist clasping the stem (not spreading outwards), attached to the axis along a J-shaped line of insertion and covering the whole length of the straight lateral merophytes; dorsal lobes asymmetrically ovate, $1.4-2.3 \times 1-1.8 \mathrm{~mm}$, strongly concave in ventral view, apex apiculate, dorsal base auriculate, auricle 100-150 $\times 125-160 \mu \mathrm{m}$, dorsal margin entire or with 1-4 triangular teeth, the teeth consisting of up to 4 cells, being 2-3 cells wide at base and ending in a row of 1-2 cells, ventral margin upcurved over most of its length, becoming flat near the apex, entire or with 3-8 triangular teeth, the teeth consisting of up to 5 cells, $2-3$ cells wide at base and ending in a row of $1-2$ cells; leaf cells elongate-hexagonal with acute ends, marginal lobe cells 10-12 $\times$ 10-12 $\mu \mathrm{m}$, median cells $32-45 \times 5-7 \mu \mathrm{m}$, basal cells $37-62 \times 17-25 \mu \mathrm{m}$, vitta cells absent, cells wall thick, trigones large, cordate to bulging and irregularly rounded, often becoming coalesced, intermediate thickenings 0-1 per cell wall, the cell lumen appearing vermicular; oil bodies Calypogeia-type, 4-5 per cell, toward leaf base more numerous, up to 8 per cell (Gradstein 3894). Lobules rectangular, 


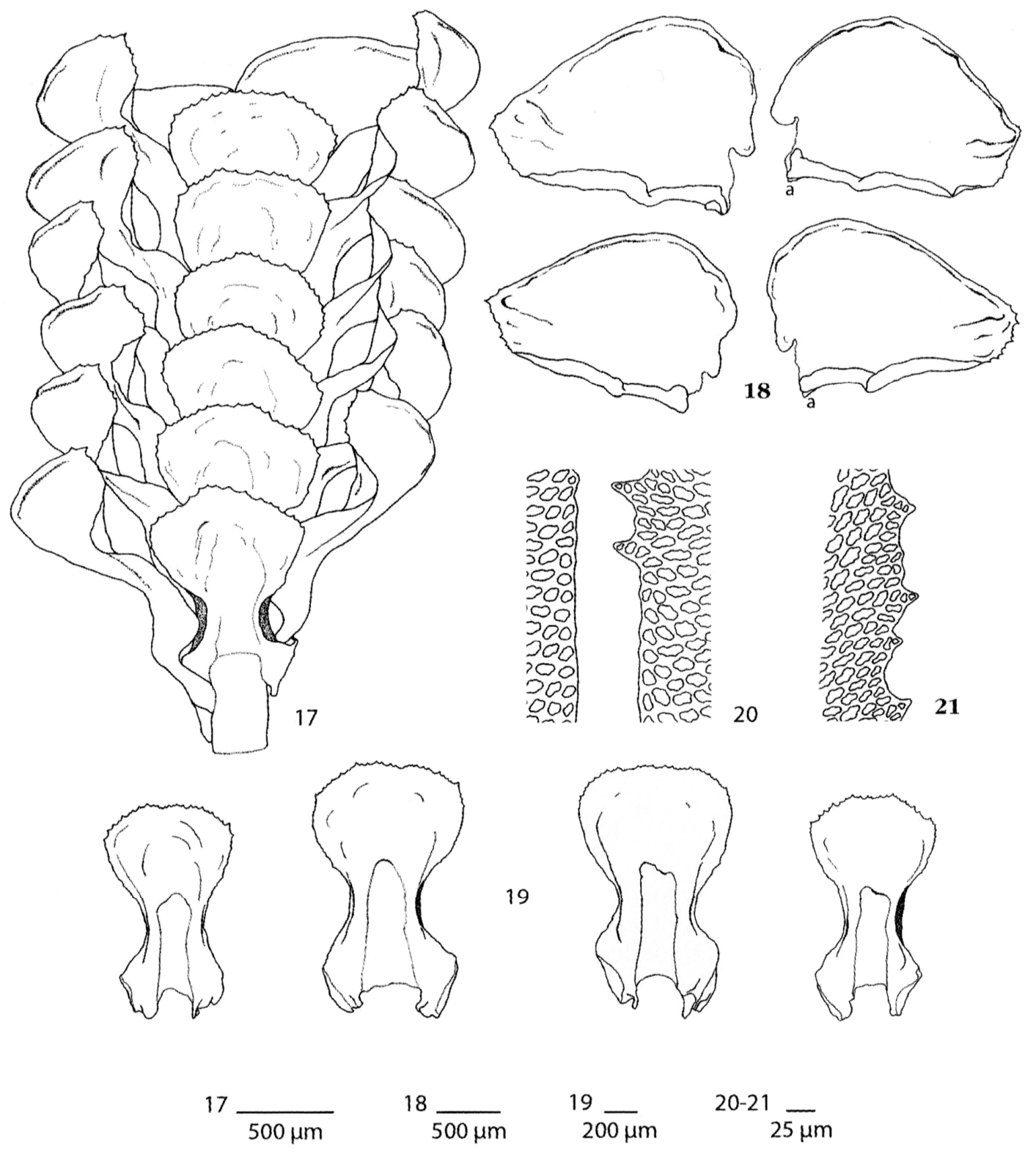

Figs 17-21. Thysananthus discretus Sukkharak et Gradst. 17. Portion of shoot, ventral view. 18. Leaves, ventral view. 19. Underleaves. 20. Dorsal margin cells of leaf lobe. 21. Ventral margin cells of leaf lobe. (All from Streimann 13622 [JE]). a = appendage.

0.6-0.7 $\times 0.1-0.2 \mathrm{~mm}, \pm 1 / 4 \times$ lobe length, inflated, keel curved, the surface smooth; foliar appendages under keel on one or both sides or not developed, orbicularoblong, 215-375 $\times 85-150 \mu \mathrm{m}$; the free margin and keel meeting each other at an oblique angle of ca. $45^{\circ}$, free margin slightly upcurved, apex with one triangular tooth, the tooth consisting of 5-12 cells, 2-4 cells wide at base and ending in a row of 1-2 cells; hyaline papilla pyriform, $25-27 \times 12-15 \mu \mathrm{m}$, at or near the proximal base of the tooth on the inner surface of the lobule. Underleaves imbricate, broadly oblong to rectangular, 1.2-1.9 $\times 0.8-1.4 \mathrm{~mm}, 2-2.5 \times$ stem width, apex broadly rounded to truncate, toothed, the teeth consisting of 1-6 cells, 2-3 cells wide at base and ending in a row of 1-2 cells, margins entire, recurved, central region gibbous, underleaf bases auriculate, the auricles 100-275 $\times 200-400 \mu \mathrm{m}$, 
underleaf bases not connected with leaves, insertion line slightly arched; cells $20-25 \times 5-7 \mu \mathrm{m}$, becoming longer towards the base of the underleaf; underleaf attachment bistratose. Dioicous. Androecia terminal-intercalary on lateral branches, bracts and bracteoles in 6-10 pairs, bracts hypostatic, ovate, 0.7-0.8 $\times$ 0.5-0.6 mm, apex acute, margins entire, lobules strongly inflated; bracteoles similar to underleaves; antheridia 2 per bract. Gynoecia terminal on elongated branches, with 2 lejeuneoid innovations, innovations repeatedly fertile, forming a dichasial pattern; bracts in one pair, obliquely spreading to subsquarrose, lobe ovate, $2.4-2.7 \times 1.2-1.5 \mathrm{~mm}$, apex apiculate, with 8-9 triangular teeth, the teeth consisting of 3-5 cells, 2-3 cells wide at base and ending in a row of 1-2 cells, appendages under keal on one or both sides or not developped, orbicular-oblong $48-95 \times 25-55 \mu \mathrm{m}$; lobules broadly ovate, $2 / 3 \times$ lobe length, apex apiculate, appendages on middle of basal part or not developped, orbicular-oblong $30-42 \times 13-25 \mu \mathrm{m} ;$ bracteoles spathulate, $2.3-2.4 \times 1.1-1.3 \mathrm{~mm}$, apex emarginate, $1 / 2 \times$ bracteole length with triangular teeth, the teeth consisting of 3-7 cells, 2-3 cells wide at base and ending in a row of 1-2 cells, margins entire, slightly recurved, central region gibbous. Perianths exserted to $1 / 2$, oblong, 2.5-2.6 $\times 1.1-1.3 \mathrm{~mm}$, apex truncate, surface sharply 3-keeled, keels in upper $1 / 3$ with numerous laciniate teeth, the teeth 3-9 cells long; beak 97-125 $\mu \mathrm{m}, 4-7$ cells long; appendages on basal part of keel or not developped. Sporophyte not seen.

Chemistry: sesquiterpenes, diterpenes and sterols (Gradstein et al., 1985, under T. convolutus sample nr. 49).

Distribution and ecology: Thysananthus discretus is thus far known only from Western Melanesia: Papua (Indonesia), Papua New Guinea and the Solomon Islands. It occurs in rain forests and montane cloud forests and was collected at $760-2700 \mathrm{~m}$. The new species grows as an epiphyte on tree trunks, branches and stems of treelets. In the view of its local abundance, it indicates that the flora of Western Melanesia still remains poorly known and that exciting discoveries may still be made in this floristically unusually rich part of the world.

Additional illustration: Gradstein et al. (2002, p. 73, Fig. 45, as T. convolutus).

Specimens examined:

INDONESIA. PAPUA: the type specimens; Cycloop Mts., Royen \& Sleumer 5907 (JE, L). - WEST PAPUA: Eipomek-Tal, 4 ${ }^{\circ} 5^{\prime}$ S 140 01' E, Hiepko \& Schultze-Motel 2218, 2403 (JE).

PAPUA NEW GUINEA. CENTRAL: Boridi, Carr 13531 (JE). - EASTERN

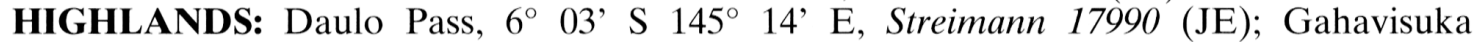
Provincial Park, $6^{\circ} 01^{\prime}$ 'S $145^{\circ} 25^{\prime}$ E, Streimann 18201 (JE). - MOROBE: Wau, Mt. Kaindi, Gradstein 3778, 3856, 3894, 3910 (GOET), Schuster 67-5786, 67-5787, 67-5792, 67-5791/c, 676282 (JE), Streimann 22497 (JE, LAE), Streimann \& Bellamy 17690 (JE, S, W); Araulu logging area, $7^{\circ} 28^{\prime}$ S $146^{\circ} 48^{\prime}$ E, Streimann 13622 (JE, LAE); Slate Creek \& Gumi Creek Divide, $7^{\circ} 10^{\prime} \mathrm{S} 146^{\circ} 28^{\prime}$ E, Streimann 13861 (JE); Spreader Divide, $7^{\circ} 16^{\prime} \mathrm{S} 146^{\circ} 06^{\prime} \mathrm{E}$, Streimann \& Tamba 11878 (JE, LAE), Streimann 11846 (LAE), Streimann 26036 (JE); Aseki-Bulolo Road, Streimann 20051, 20103, 26135 (JE). - WESTERN HIGHLANDS: Jimi-Waghi Divide, 5 43' S 144 38' E, Streimann 20916 (JE, LAE), 20911 (LAE).

SOLOMON ISLANDS. GUADALCANAL: Mt. Papomanatsen, Braithwaite 4773 (JE).

\section{DISCUSSION}

Thysananthus is subdivided into two subgenera, subgen. Thysananthus and subgen. Sandeanthus B. Thiers et Gradst., based on differences in leaf position and areolation (Thiers \& Gradstein, 1989). The new species $T$. discretus is a member of 
subgenus Thysananthus and is recognized the underleaf bases, which are not connate with the leaves, the presence of well-developed auricles at underleaf bases, the strongly rigid stems with 14-18 cells wide ventral merophytes, and the leaves which, when moist, are clasping the stem. Free underleaf bases, which are not connate with the leaves, is an unusual character in Thysananthus and occur otherwise in the New Guinean endemics T. mollis and T. montanus, and (occasionally) in the widespread $T$. retusus. These three species are readily distinguished from $T$. discretus by the vittate leaves. All other species of Thysananthus have leaves that are connate with the underleaf bases on one side (Sukkharak \& Gradstein, submitted). The differences between $T$. discretus and other members of the genus are shown in the key to species of Thysananthus given below.

Collections of Thysananthus discretus were previously identified as "T. appendiculatus", "T. convolutus", or "T. sp.". The new species is most closely related to widespread Malesian T. convolutus and was illustrated as T. convolutus by Gradstein et al. (2002: Fig. 45). The illustration clearly shows the free underleaves characteristic of the new species, which are not connected with the leaves, and the presence of well-developed auricles at the underleaf bases. $T$. discretus shares with $T$. convolutus the asymmetric leaves but differs from the latter by (1) leaves when moist clasping the stem (squarrose in T. convolutus), (2) free underleaf bases, with well-developed auricles (underleaf bases connate with leaves on one side and without auricles in T. convolutus), and (3) strongly rigid stems, with 14-18 cells wide ventral merophytes and medulla 16-22 cell layers high (less rigid stems, with 8-10 cells wide ventral merophytes and 14-17 layers high medulla in $T$. convolutus). The new species may also be confused with T. appendiculatus, a species endemic to New Guinea which may possess auricled underleaf bases like T. discretus. However, the leaf lobes in T. appendiculatus are symmetric and widely spreading when moist, while in $T$. discretus they are asymmetric and clasping the stem when moist. In addition, leaf and underleaf bases are connected in T. appendiculatus while in T. discretus they are never connected.

A foliar appendage is developed at the base of the keel in leaves (Figs 2, 18) and bracts, the mid-basal portion of bract lobules (Fig. 4), and perianths of Thysananthus discretus. Foliar appendages may occur on bracts and perianths in all species of Thysananthus but are rare on vegetative leaves (only in T. discretus, T. appendiculatus and T. convolutus; Sukkharak \& Gradstein, submitted). In T. discretus the appendages are present on one or both sides of the stem and are sometimes lacking, while in T. appendiculatus and T. convolutus they are always found on one side of the stem only, on leaves that are free from underleaf bases and opposite to leaves that are connected with underleaf bases. Moreover, the foliar appendages of $T$. convolutus are always curved towards the stem while in $T$. discretus and T. appendiculatus they are straight or curved.

Thysananthus discretus is a rather polymorphic species with respect to the dentation of leaves, which varies from edentate (Figs 1,2 ) to \pm strongly dentate (Figs 17, 18). The variation in leaf dentation observed in $T$. discretus is not uncommon in Lejeuneaceae, however, and also occurs in, e.g., T. convolutus, Bryopteris filicina (Swartz) Nees (Gradstein, 1994), Archilejeunea planiuscula (Mitt.) Steph. (Thiers \& Gradstein, 1989; Gradstein et al., 2002), and in the genus Lejeunea (Reiner-Drehwald \& Goda, 2000).

\section{Key to the species of Thysananthus}

1. Leaves when dry convolute. Leaf cells elongate (Thysananthus subgen.

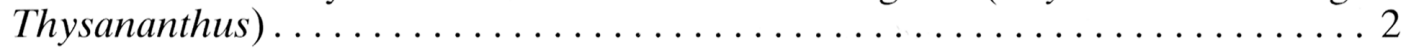


1. Leaves when dry widely spreading, loosely reflexed or plane. Leaf cells (except for vitta) subisodiametric (Thysananthus subgen. Sandeanthus) . . . . T. retusus 2. Leaf lobes without vitta. Underleaf bases free or connected with leaves on one

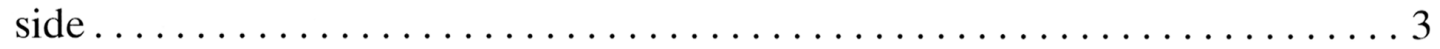

2. Leaf lobes with vitta. Underleaf bases free. . . . . . . . . . . . . . . . . .99

3. Leaf lobes asymmetrical with the apex positioned towards the ventral side of the

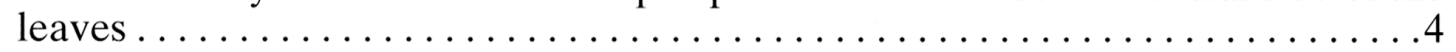

3. Leaf lobes symmetrical, apex not positioned towards the ventral side of the

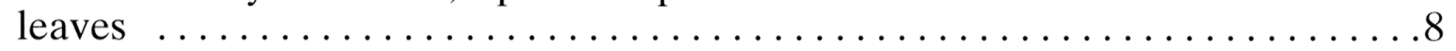
4. Leaves when moist squarrose or clasping the stem. Underleaf bases free or

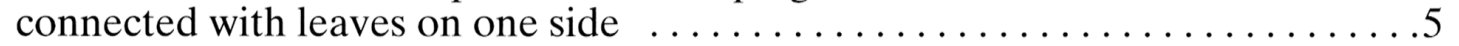
4. Leaves when moist spreading out widely. Underleaf bases connected with

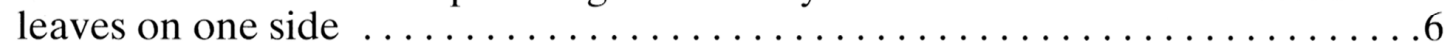

5. Ventral merophyte 14-18 cells wide. Leaves when moist clasping the stem. Underleaf bases free, with well-developed auricles . . . . . . . . T. discretus

5. Ventral merophyte 8-10 cells wide. Leaves when moist squarrose. Underleaf bases connected with leaves on one side, without auricles ......T. convolutus 6. Underleaves spathulate, recurved. Male bract lobules epistatic or hypostatic. Neotropical ............................. T. amazonicus 6. Underleaves obovate, flat or channeled/hollow. Male bract lobules hypostatic. Paleotropical. ....................................

7. Dorsal base of leaves auriculate. Underleaves flat. Perianth laciniate, teeth 3-5

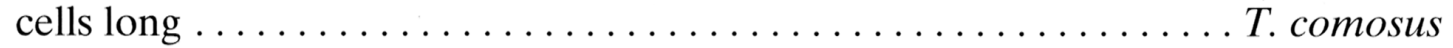

7. Dorsal base of leaves without auriculate. Underleaves channeled/hollow. Perianth dentate, teeth $1-2$ cells long. ................ T. aculeatus 8. Keel of leaves on one side of the stems with a foliar appendages (on the side where leaves and underleaves are free $) \ldots \ldots \ldots \ldots \ldots$ T appendiculatus 8. Keel of leaves without foliar appendage............ T. spathulistipus

9. Leaves when dry convolute or laterally appressed to the stem. Leaves

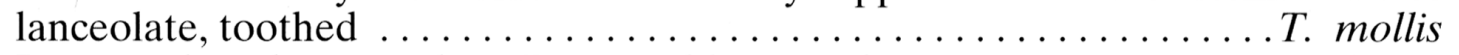

9. Leaves when dry convolute. Leaves oblong, entire.......... T. montanus

Acknowledgments. The research of the first author was supported by a Royal Thai government scholarship in cooperation with the German Academic Exchange Service (DAAD).

\section{REFERENCES}

GRADSTEIN S.R., 1975 - A taxonomic monograph of the genus Acrolejeunea (Hepaticae). Vaduz, J. Cramer, 162 p.

GRADSTEIN S.R., 1994 - Lejeuneaceae: Ptychantheae, Brachiolejeuneae. Flora neotropica 62: 1-216.

GRADSTEIN S.R., MATSUDA R. \& ASAKAWA Y., 1985 - A chemotaxonomic survey of terpenoids and aromatic compounds in the Lejeuneaceae (Hepaticae). Beihefte zur Nova Hedwigia 80: 63-86.

GRADSTEIN S.R., HE X.-L., PIIPPO S. \& MIZUTANI M., 2002 - Bryophyte flora of the Huon Peninsula, Papua New Guinea. LXVII. Lejeuneaceae subfamily Pychanthoideae (Hepaticae). Acta botanica Fennica 174: 1-88.

MIZUTANI M., 1961 - A revision of Japanese Lejeuneaceae. Journal of the Hattori botanical laboratory 24: 115-302.

REINER-DREHWALD M. E. \& GODA A., 2000 - Revision of the genus Crossotolejeunea (Lejeuneaceae, Hepaticae). Journal of the Hattori botanical laboratory 89: 1-54.

THIERS B. M. \& GRADSTEIN S. R., 1989 - Lejeuneaceae (Hepaticae) of Australia. I. Subfamily Ptychanthoideae. Memoirs of the New York botanical garden 52: 1-79. 


\section{On the occurrence of adnate underleaves and appendages in Thysananthus (Lejeuneaceae). Studies on the genus Thysananthus, 2.}

Fusion of underleaf bases with the bases of adjacent leaves is a rather common phenomenon in the order Jungermanniales (Heinrichs et al. 2005; He-Nygrén et al., 2006), especially in species of Bazzania and Lophocoleaceae (Chiloscyphus, Clasmatocolea, Heteroscyphus, Leptoscyphus, etc.) (e.g. Fulford, 1963, 1976; Engel, 1980; Piippo, 1985; Srivastava \& Srivastava, 2002). Underleaves in these groups may be adnate with leaves on one or both sides, or free, and this character may sometimes be useful to separate closely related species. In contrast, adnate underleaves are very rare in the order Porellales (Frullaniaceae, Lejeuneaceae, Porellaceae, etc.) where they occur commonly only in the genus Thysananthus (but adnate female bracteoles occur in Ceratolejeunea, Drepanolejeunea, Lejeunea and Leptolejeunea; Zhu \& So, 2001; Dauphin, 2003; Zhu \& Grolle, 2003). Several authors have paid attention to the occurrence of adnate underleaves in Thysananthus but the descriptions and taxonomic interpretations were sometimes contradictory. In this paper, we briefly examine the occurrence of adnate underleaves, and some further littleknown leaf-base features, in the genus Thysananthus.

Thysananthus (Lejeuneaceae subfamily Ptychanthoideae) is a genus of about 11 species occurring mostly in Southeast Asia and is a characteristic element of tropical lowland and montane rainforests (Sukkharak, in prep.). Mizutani (1969) first observed that underleaves of $T$. spathulistipus were connected with the basal part of keels of the leaves. He showed that when an underleaf is removed from the stem, the basal portion of the underleaf remains attached to the base of the keel of the lateral leaves, as an appendage. Later, Mizutani (1977) reported adnate underleaves in $T$. aculeatus Herzog and $T$. convolutus Lindenb. (and its synonym $T$. gottschei (Jack \& Steph.) Steph.), and concluded that these species were therefore closely related. Kitagawa (1973) observed adnate underleaves in T. appendiculatus Steph., a species having large appendages where underleaves are detached (hence the name appendiculatus), and concluded that separation of this species from $T$. spathulistipus was not warranted. Mizutani \& Piippo (1986), however, noted that appendages in T. appendiculatus occur on both sides of the stem while being absent or on one side of stem only in $T$. spathulistipus, and maintained the two as separate species.

Our study of a large series of specimens of all species of Thysananthus shows that underleaves in Thysananthus may be free or adnate to the keel of the leaves on one side of the stem, never on both sides (Fig. 1A, B and D; adnate portion running from the base of the underleaf to ' $\mathrm{e}$ '). We are unable to confirm the observation of Mizutani \& Piippo (1986) that underleaves in $T$. appendiculatus are adnate on both sides. The presence of adnate underleaves appears to be a stable and taxonomically relevant feature of $T$. aculeatus, $T$. 

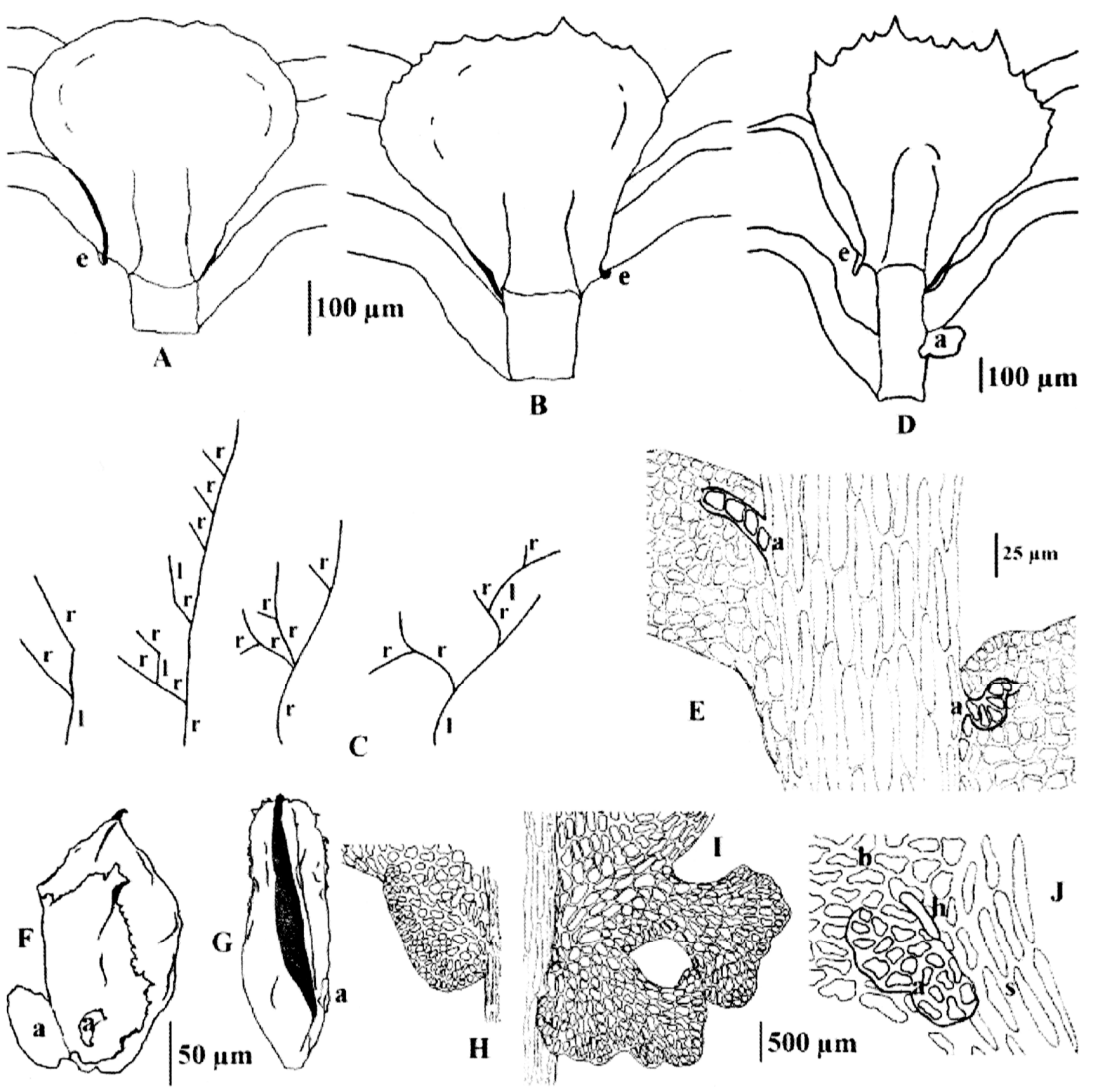

Figure 1. Adnate underleaves and appendages in Thysananthus. (A and B) Stem in ventral view showing adnate underleaf; e=distal end of the connection between leaf and underleaf. (C) Diagrams of branch systems; $1=$ underleaves adnate on left-hand side, $r=$ underleaves adnate on right-hand side. (D) Appendage (a) at keel of leaf. (E) Appendage (a) at lobule base. (F) Appendages (a) at keel and lobule base of female bract. (G) Appendages (a) at perianth base. (H-I) Appendages of leaf keels. (J) Appendage of lobule base; $a=a p p e n d a g e, b=l o b u l e, ~ h=h y a-$ line papilla, s=stem (A-C drawn from T. comosus, Wallich s.n. (BM); D drawn from T. appendiculatus, Clemens 5414 (W); E drawn from T. retusus, Sukkharak 733 (GOET); F and H drawn from T. discretus, van Royen \& Sleumer 5896 (L); G drawn from T. mollis, Gradstein 3795 (GOET); I drawn from T. appendiculatus, Gradstein 3875 (GOET); J drawn from T. montanus, Streimann 13639 (LAE)).

amazonicus (Spruce) Schiffn., T. appendiculatus, T. comosus Lindenb., T. convolutus, T. laceratus Steph. and T. spathulistipus (Reinw. et al.) Lindenb.); in the other species of the genus $(T$. discretus Sukkharak \& Gradst. (Sukkharak \& Gradstein, 2010), T. mollis Steph., T. montanus Gradst., X.L. He \& Piippo and T. retusus (Reinw. et al.) B. Thiers \& Gradst.) underleaf bases are usually free.

Interestingly, it appeared that the adnation of underleaves on branches occurs in a distinct left-right symmetry pattern, on right-hand branches being connected to leaves on the left side and on left-hand branches on the right-hand side (Fig. 1C). The left-right correlation between branches and underleaf adnation observed in Thysananthus has, to our knowledge, not yet been reported from liverworts and deserves further study in other genera with adnate underleaves. A more detailed analysis might be rewarding and could shed more light on the evolutionary and systematic implications of this phenomenon.

Associated with leaf bases, we have observed an additional morphological feature in Thysananthus. In all species of Thysananthus, a small foliar 'appendage' may be developed on leaves, female bracts and perianths (Fig. 1D-G). These appendages, which are not to be confused with the ones discussed above, are irregular in shape (Fig. $1 \mathrm{H}-\mathrm{J}$ ) and vary somewhat in size and position. In $T$. appendiculatus, $T$. laceratus and $T$. discretus, the appendages are found on the keel of leaves and inserted partially on the stems. In $T$. appendiculatus and $T$. laceratus, they are always found on one side of the stem only, on the side where underleaves are free and being opposite to the adnate ones (Fig. 1D). In species with free underleaves such as $T$. discretus, however, the position of the appendages is variable and may be on one or both sides of the stems (or lacking). These observations are further evidence for the left-right symmetry on branches in Thysananthus. In T. mollis, T. montanus and T. retusus, moreover, we observed an appendage which is attached to the lobule bases and the stem epidermis cells (Fig. 1E). The appendage is oblong in shape, $45-85 \times 22-45 \mu \mathrm{m}$ in size (Fig. 1J) and developed on both sides of the stem. This structure should not be confused with the stylus, which is the characteristic of Frullaniaceae, Jubulaceae and Lejeuneaceae (Cololejeunea and Lejeunea) (e.g. Leitgeb, 1880, p. 12; Benedix, 1953; Grolle, 1975; Reiner-Drehwald, 2000; Wigginton, 2006). By its position, these structures are different. The appendage runs below the margin base of 
lobule and is also inserted on the stem, whereas the stylus is always inserted on the margin base of a lobule.

In all Thysananthus species, wing-like appendages occur on the keels of the female bracts, on one or both sides of the stem (or lacking) and partially inserted on the associated innovation. In addition, a small appendage may be found on the mid-basal portion of the bract lobules and on the base of the keels of the perianth (Fig. 1F-G). The appendages on the female bracts are not associated with left-right symmetry and their presence is a generic feature of Thysananthus, without relevance for species recognition. The presence of an appendage along the keel of the female bracts is also characteristic of Brachiolejeunea, Frullanoides and Harpalejeunea, and occurs furthermore also in Blepharolejeunea, Lindigianthus, Neurolejeunea, Mastigolejeunea and Spruceanthus where it is small and sometimes lacking (van Slageren, 1985; Gradstein, 1994; Daniels, Kariyappaa \& Daniel, 2010). The available evidence indicates that appendages on female bracts occur widely in family Lejeuneaceae.

The taxonomic value of the adnate underleaves and appendages in Thysananthus is shown in the following key to the species of the genus:

1. Underleaf bases connected with leaves on one side

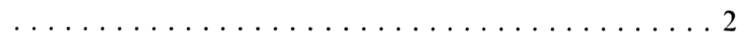

1. Underleaf bases usually free . . . . . . . . . 3

2. Keel of leaves on one side of the stems with a small foliar appendage (on the side where leaves and underleaves are free). . . . . . appendiculatus and T. laceratus

2. Keel of leaves without foliar appendage...T. aculeatus, T. amazonicus, T. comosus, T. convolutus and T. spathulistipus

3. Lobule bases with small appendages (attached to stem epidermis cells); keel of leaves without foliar appendage ......... T. mollis, T. montanus and T. retusus

3. Lobule bases without appendage; keel of leaves on one or both sides of the stem with small foliar appendage, or appendage lacking $\ldots \ldots \ldots \ldots \ldots . \ldots \ldots$. discretus

We are grateful to the curators of the herbaria BM, L, LAE and $\mathrm{W}$ for the loan of specimen and to Dr M. Elena ReinerDrehwald and an anonymous reviewer for advice. Work by the first author was supported by a Royal Thai government scholarship in cooperation with the German Academic Exchange Service (DAAD).

Taxonomic Additions and Changes: Nil.

\section{REFERENCES}

Benedix E. 1953. Indomalayische Cololejeuneen. Feddes Repertorium specierum novarum regni vegetabilis 134: 1-88.
Daniels AED, Kariyappaa KC, Daniel P. 2010. A new species of Spruceanthus Verd. (Hepaticae: Lejeuneaceae) from the Western Ghats of India. Cryptogamie, Bryologie 31: 121-123.

Dauphin G. 2003. Ceratolejeunea. Flora Neotropica Monograph 90: 1-86.

Engel JJ. 1980. A monograph of Clasmatocolea (Hepaticae). Fieldiana Botany New Series 3: 1-229.

Fulford MH. 1963. Manual of the Leafy Hepaticae of Latin America Part I. Memoirs of the New York Botanical Garden 11: 1-172.

Fulford MH. 1976. Manual of the Leafy Hepaticae of Latin America Part IV. Memoirs of the New York Botanical Garden 11: 393535.

Gradstein SR. 1994. Lejeuneaceae: Ptychantheae, Brachiolejeunea. Flora Neotropica 62: 1-216.

Grolle R. 1975. Miscellanea Hepaticologica 141-150. Journal of Bryology 8: 483-492.

Heinrichs J, Gradstein SR, Wilson R, Schneider H. 2005. Towards a natural classification of liverworts (Marchantiophyta) based on the chloroplast gene rbcL. Cryptogamie, Bryologie 26: 131150.

He-Nygrén X, Juslén A, Ahonen I, Glenny D, Piippo S. 2006. Illuminating the evolutionary history of liverworts (Marchantiophyta) - towards a natural classification. Cladistics 22: $1-31$.

Kitagawa N. 1973. Miscellaneous notes on little-known species of Hepaticae, 26-50. Journal of the Hattori Botanical Laboratory 37: 263-273.

Leitgeb H. 1880. Untersuchungen üeber die Lebermoose. II. Die foliosen Jungermannieen. Jena: O. Deisting.

Mizutani M. 1969. Lejeuneaceae subfamily Ptychanthoideae from Sabah (North Borneo). Journal of the Hattori Botanical Laboratory 32: $129-139$.

Mizutani M. 1977. Lejeuneaceae from Philippines. Journal of the Hattori Botanical Laboratory 43: 127-136.

Mizutani M, Piippo S. 1986. Some species of Lejeuneaceae from New Guinea. Journal of the Hattori Botanical Laboratory 61: 477485.

Piippo S. 1985. Bryophyte flora of the Huon Peninsula, Papua New Guinea, XII. Geocalycaceae (Hepaticae). Acta Botanica Fennica 131: 129-167.

Reiner-Drehwald ME. 2000. Las Lejeuneaceae (Hepaticae) de Misiones, Argentina VI. Lejeunea y Taxilejeunea. Tropical Bryology 19: 81131.

Slageren MW van. 1985. A taxonomic monograph of the genera Brachiolejeunea and Frullanoides. Mededelingen van het Botanisch Museum en Herbarium van de Rijksuniversiteit te Utrecht 544: 1309.

Srivastava A, Srivastava SC. 2002. Indian Geocalycaceae (Hepaticae). Dehra Dun: Bishen Singh Mahendra Pal Singh.

Sukkharak P, Gradstein SR. 2010. Studies on the genus Thysananthus (Marchantiophyta: Lejeuneaceae). 1. Thysananthus discretus Sukkharak \& Gradst. spec. nov. Cryptogamie, Bryologie 31: 113119.

Wigginton M. 2006. Bryophytes of St Helena, South Atlantic Ocean. 1. Three new species of Cololejeunea (Jungermanniales, Lejeuneaceae), $C$. dianae sp. nov., $C$. sanctae-helenae sp. nov. and C. grossestyla sp. nov. Journal of Bryology 28: 363-373.

Zhu RL, So ML. 2001. Epiphyllous liverworts of China. Nova Hedwigia Beiheft 121: 1-418.

Zhu RL, Grolle R. 2003. On the genus Capillolejeunea (Lejeuneaceae, Hepaticae) from the East African Islands. Systematic Botany 28: 467-470. 


\title{
Studies on the genus Thysananthus (Marchantiophyta, Lejeuneaceae) 3. Terpenoid chemistry and chemotaxonomy of selected species of Thysananthus and Dendrolejeunea fruticosa
}

\author{
Phiangphak SUKKHARAK ${ }^{*}$, Agnieszka LUDWICZUK ${ }^{b}$, Yoshinori ASAKAWA ${ }^{c}$ \& Robbert \\ GRADSTEIN ${ }^{d}$ \\ ${ }^{a}$ Department of Systematic Botany, Albrecht von Haller Institute of Plant Sciences, University \\ of Göttingen, Untere Karspüle 2, 37073 Göttingen, Germany \\ ${ }^{b}$ Department of Pharmacognosy with Medicinal Plant Unit, \\ Medical University of Lublin, 1 Chodzki Street, 20-093 Lublin, Poland \\ ${ }^{c}$ Faculty of Pharmaceutical Sciences, Tokushima Bunri University, Yamashiro-cho, \\ Tokushima, 770-8514, Japan \\ ${ }^{d}$ Muséum National d'Histoire Naturelle, Dept. Systématique et Evolution, UMS 7205, Case \\ Postale 39, 57 rue Cuvier, 75231 Paris cedex 05, France
}

(Received 20 October 2010, accepted 26 March 2011)

\begin{abstract}
Gas chromatography and mass spectrometry of 20 samples of Thysananthus (T. comosus, T. convolutus, T. retusus, T. spathulistipus) and one of Dendrolejeunea (D. fruticosa) from Malaysia and Thailand revealed the presence in most taxa of large quantities of sesquiterpenoids and unidentified diterpenoids. Isolepidozene was detected as a major component in T. comosus, T. convolutus and T. spathulistipus, pinguisane sesquiterpenoids as major components in T. retusus, and the unidentified $\left(\mathrm{M}^{+}\right) 304,271(100), 105(90)$ as the most abundant component of $D$. fruticosa. The large chemical heterogeneity detected in $T$. convolutus correlates with the variation in leaf dentation observed in the species and supports the resurrection of $T$. gottschei, previously considered a synonym of $T$. convolutus. The subdivision of Thysananthus into two subgenera, subg. Thysananthus and subg. Sandeanthus, and the treatment of Dendrolejeunea as a separate genus, are chemically supported.
\end{abstract}

Dendrolejeunea fruticosa/ diterpenoids/ GC-MS/ liverwort/ sesquiterpenoids/ Thysananthus comosus/ Thysananthus convolutus/ Thysananthus retusus/ Thysananthus spathulistipus/ volatiles

\section{INTRODUCTION}

\footnotetext{
*Correspondence and reprints: ppsukk@gmail.com
} 
Liverworts are able to synthesize large quantities of terpenoids, especially sesquiterpenoids, diterpenoids and lipophilic aromatic compounds, which are stored in oil bodies (e.g., Gradstein et al., 1985). The Lejeuneaceae are the largest family of liverworts with about 1200 species in 78 genera (Frey \& Stech, 2009, with updates). Several studies have been conducted on the terpenoids and aromatic compounds of Lejeuneaceae (e.g., Asakawa, 1982, 1995, 2004; Asakawa et al., 1980a, 1980b; Gradstein et al., 1981, 1985, 1988; Kruijt et al., 1986). These substances, especially terpenoids, often show strong biological activity and may play an important role in the defence of the plants against environmental hazards (Gradstein, 1994) or predators (Harinantenaina et al., 2006). The above-mentioned studies also identified some substances as taxonomic markers for members of the family.

Thysananthus Lindenb. is a member of Lejeuneaceae subfamily Ptychanthoideae Mizut. (Mizutani, 1961; Gradstein, 1975, 1994). The genus is characterized by (1) purely Lejeunea-type vegetative branches, (2) ventral merophyte 4-12 cells wide, (3) stem epidermis cells not larger than medullary cells, with thick, brownish walls, (4) leaves convolute when dry, usually toothed, (5) leaf cells elongate, (6) gynoecial innovations with lejeuneoid leaf sequence, and (7) perianth with 3(-10) keels (Thiers \& Gradstein, 1989; Gradstein, 1992; Gradstein et al., 2002; Sukkharak \& Gradstein, 2010a). Thus defined, the genus contains ten species rowing as epiphytes in moist lowland forests and montane cloud forests throughout the tropics (Sukkharak \& Gradstein, 2010a). The centre of diversity is in Southeast Asia with five species (T. aculeatus Herzog, T. comosus Lindenb., T. convolutus Lindenb., T. retusus (Reinw. et al.) B. Thiers \& Gradst., T. spathulistipus (Reinw. et al.) Lindenb.). Thysananthus spathulistipus also reaches to tropical Africa. Three species are found in New Guinea and the Solomon Islands (T. discretus Sukkharak \& Gradst., T. mollis Steph., T. appendiculatus Steph.) and one is only known from Papua New Guinea (T. montanus Gradst. et al.). Finally, one species, T. amazonicus (Spruce) Schiffn., is known from the New World tropics. The species of Thysananthus are attributed to the two subgenera: subg. Thysananthus ( $T$. aculeatus, T. amazonicus, T. appendiculatus, T. comosus, T. convolutus, T. discretus, T. mollis, T. montanus, T. spathulistipus) and subg. Sandeanthus B. Thiers \& Gradst. (T. retusus) (Thiers \& Gradstein, 1989; Gradstein, 1992, with updates).

Dendrolejeunea is a monotypic genus, containing only D. fruticosa (Lindenb. \& Gottsche) Lacout. from tropical Asia, northern Australia and the Pacific region. First described by Spruce (1884) as a subgenus of Lejeunea, Dendrolejeunea was long included in Thysananthus but was resurrected as a separate genus by Gradstein (1992). Morphologically, Dendrolejeunea stands out by its dendroid habit, having creeping stoloniform stems and 
upright, regularly pinnate branches. In contrast, members of Thysananthus are never dendroid and share projecting growth and irregularly pinnate branching. Molecular data have revealed that Dendrolejeunea is the sister group of Thysananthus (Wilson et al., 2007).

Seven species of Thysananthus: T. amazonicus, T. appendiculatus, T. convolutus, T. discretus (under T. convolutus sample nr. 49 in Gradstein et al., 1985), T. mollis, T. retusus (under T. fruticosus in Gradstein et al., 1985) and T. spathulistipus, have been screened for the occurrence of terpenoids, flavonoids, sterols, and aromatic compounds (Gradstein et al., 1985; Kruijt et al., 1986; Harinantenaina et al., 2006). The results showed the presence of pinguisane sesquiterpenoids, clerodane diterpenoids and unidentified diterpenoids.

As part of a world-wide revision of Thysananthus by the first author, we hereby report the results of chemical analysis of four species of Thysananthus (T. comosus, T. convolutus, T. retusus, $T$. spathulistipus) and of the closely related Dendrolejeunea fruticosa.

\section{MATERIAL AND METHODS}

Plant material. Twenty samples of Thysananthus and one sample of Dendrojeunea were collected mainly by the first author and her associates in Malaysia and Thailand in 2009 (Table 1). Dried voucher specimens were deposited in BKF and GOET.

Extraction and analysis. Plant material ( $0.25 \mathrm{~g}$ of each species) was purified, airdried and crushed in mortal to receive fine powder. The powdered material was extracted three times with diethyl ether $(3 \times 3 \mathrm{ml})$ at room temperature, and the crude extract was filtered through a Pasteur pipette packed with Celite. The filtered extract was dried using anhydrous sodium sulfate as a drying agent, then evaporated to receive $100 \mu \mathrm{l}$ of extract. One $\mu \mathrm{l}$ of the crude extract was analyzed by GC-MS using an Agilent Technologies 6890N gas chromatograph coupled with a mass selective detector (Agilent Technologies 5973), on an HP-5MS capillary column (30 $\mathrm{m}$ x $0.25 \mathrm{~mm}, 0.25 \mu \mathrm{m}$ film thickness). Oven temperature was $50^{\circ} \mathrm{C}$ with 3 minutes initial hold, and then to $250^{\circ} \mathrm{C}$ temperature programmed at $5^{\circ} \mathrm{C} / \mathrm{min}$, and 15 minutes at $250^{\circ} \mathrm{C}$. Injection temperature was $280^{\circ} \mathrm{C}$ and helium $(1 \mathrm{ml} / \mathrm{min})$ was used as a carrier gas. The detector was operated in electron impact mode ( $70 \mathrm{eV}$ with 3 scans/s and mass range $m / z 40-500)$ at $230^{\circ} \mathrm{C}$. Each extract was analyzed three times. The retention indices were calculated relative to C9-C30 $n$-alkanes. Compounds were identified using a computersupported spectral library (Hochmuth, 2008), mass spectra of reference compounds, as well as MS data from the literature (Joulain \& König, 1998; Linstrom \& Mallard, 2001) and the library database of the Faculty of Pharmaceutical Sciences, Tokushima Bunri University. Compound identities were confirmed by comparison of retention indices with reference 
compounds and published data (Linstrom \& Mallard, 2001). Quantification was done based on peak area.

\section{RESULTS AND DISCUSSION}

In total, 66 different sesquiterpenoids and diterpenoids were detected in the five investigated species (21 samples). Of these, about two-thirds (42) are unidentified compounds. The taxonomic distribution and abundance of the identified and unidentified compounds are shown in Table 2, chemical structures of identified components are depicted in Figure 1. Numbers in bold face in the text refer to the compound figure numbers. The chemotaxonomic relevance of the detected compounds is discussed below.

\section{Thysananthus comosus Lindenb.}

Three compounds were detected in all four samples of Thysananthus comosus: cis- $\beta$ elemene (3), isolepidozene (13) and the unidentified $\left(\mathrm{M}^{+}\right) 220,107(100), 43(80)$. The Malaysian specimen of this species (sample 1) produces large amounts of $\left(\mathrm{M}^{+}\right) 302,190(100)$, 81(95) which was also detected as a major component in T. convolutus from Malaysia. Samples 2-4 from Thailand produce three unidentified compounds $\left(\mathbf{M}^{+}\right) 318,207(100)$, 189(60), ( $\left.\mathrm{M}^{+}\right) 318,151(100), 303(32)$ and $\left(\mathrm{M}^{+}\right) 318,119(100), 134(60)$, which have not been detected in any other analyzed Thysananthus species. In ecological respect, the samples of $T$. comosus are quite distinct. Sample 1 is from rock in coastal forest at the sea shore, whereas the other samples are from inland forests. We suggest that the deviating chemical composition of sample 1 might be due to stress, induced by the salt-spray environment. The same phenomenon is observed in the widespread holarctic Conocephalum conicum (L.) Dumort. which is made up of different geographical and chemical races. Conocephalum conicum type I is widely distributed while type II occurs in coastal locations (Wood et al., 1996). GC-massspectrometric analysis of 280 samples of $C$. conicum revealed that type I elaborates (-)sabinene as a major compound whereas type II produces large amounts of (+)-bornyl acetate (Toyota et al., 1997). Kim et al. (2001) studied the phylogenetic relationships among the two chemotypes of $C$. conicum using $p s b A$ sequences. Their results showed that the $p s b A$ sequences of $C$. conicum type I and II are identical, suggesting that they are conspecific. These finding indicate that the detected chemical differences within C. conicum are environmentally controlled, as has been suggested by Asakawa (1995) and Harinantenaina \& Asakawa (2004). In T. comosus, however, study of a larger number of samples is needed to corroborate the observed correlation between chemical constitution and habitat. 


\section{Thysananthus convolutus Lindenb.}

In all samples of $T$. convolutus relatively large amounts of isolepidozene (3) were detected. However, the samples from Malaysia (1-3) and Thailand (4, 5) are chemically different. Large amounts of the unidentified diterpenoid $\left(\mathrm{M}^{+}\right) 302$, 190(100), 81(95) were detected in the Malaysian samples whereas those from Thailand produce large amounts of $\left(\mathrm{M}^{+}\right) 302,81(100)$, 185(60), which was absent in the samples from Malaysia. The chemical dissimilarity of the samples of $T$. convolutus is reflected in the morphology, as the samples from Malaysia have entire leaves, whereas Thai samples have toothed leaves. Thysananthus convolutus is a polymorphic species with respect to the dentation of leaves, underleaves and female bracts, which varies from strongly dentate to edentate. The edentate form has been called T. gottschei (Jack \& Steph.) Steph., which was reduced to a synonym of $T$. convolutus (Grolle \& Piippo, 1984). Our data suggest that T. gottschei may have to be resurrected as a separate taxon. This taxonomic issue will be addressed in a more broadly-based, monographic study (Sukkharak, submitted).

\section{Thysananthus retusus (Reinw. et al.) B. Thiers \& Gradst.}

Pinguisane sesquiterpenoids are detected as major compounds in all 4 samples of $T$. retusus. The presence of $\alpha$-pinguisene (10) and deoxopinguisone (19), reported earlier from T. retusus (under T. fruticosus) by Gradstein et al. (1985), is confirmed. Another abundant compound occurring only in this species is an unidentified diterpenoid $\left(\mathrm{M}^{+}\right) 318,81(100)$, 206(98). The chemical constitution of the samples of T. retusus is rather different from that of the other analyzed Thysananthus species. The chemical data are supportive of the classification of Thysananthus into 2 subgenera, subg. Thysananthus and subg. Sandeanthus, based on morphology (Thiers \& Gradstein, 1989; Gradstein, 1992). Thysananthus mollis and T. planus Sande Lac. (= T. retusus) were earlier placed in section Vittatae by Verdoorn (1934), together with Dendrolejeunea fruticosa (= T. fruticosus), but this section was broken up by Thiers \& Gradstein (1989). Morphologically, Thysananthus mollis and T. retusus share the presence of a vitta in the leaves and appendages on the leaf lobules (Sukkharak \& Gradstein, 2010b). Chemically, however, the two species seem to be quite different, T. mollis being poor in sesquiterpenoids (Gradstein et al., 1985).

\section{Thysananthus spathulistipus (Reinw. et al.) Lindenb.}

In all analyzed samples of Thysananthus spathulistipus quite large amounts of isolepidozene (13) were found. Five from the seven samples produce pinguisane sesquiterpenoids. Samples 3 and 5, and also sample 1 (small amount), biosynthesize the 
unidentified diterpenoid $\left(\mathrm{M}^{+}\right) 318,125(100)$, 81(38). Compounds $\left(\mathrm{M}^{+}\right) 360,81(100)$, 43(80), $\left(\mathrm{M}^{+}\right) 360,81(100), 43(90)$ and $\left(\mathrm{M}^{+}\right) 374,43(100), 81(58)$ are abundantly present in samples 4, 6 and 7. Sample 2 differs from the others by the presence of large amounts of compounds $\left(\mathrm{M}^{+}\right) 302$, 95(100), 81(82) and $\left(\mathrm{M}^{+}\right) 320,207(100)$, 81(83). The latter compound is also abundantly present in the Malaysian samples of $T$. convolutus. Morphologically, however, sample 2 fits $T$. spathulistipus as currently conceived. The data suggest that $T$. spathulistipus is chemically a rather variable species.

\section{Dendrolejeunea fruticosa (Lindenb. \& Gottsche) Lacout.}

The investigated sample of Dendrolejeunea fruticosa differs chemically from the analyzed Thysananthus species by the presence of the sesquiterpenoid alcohol guaia-6,9-dien$4 \beta$-ol (20) and an unidentified diterpenoid $\left(\mathrm{M}^{+}\right) 304,271(100), 105(90)$ as the two most abundant components. Interestingly, fusicocca-2,5-diene (37) detected in all samples of $T$. retusus was also found in the sample of $D$. fruticosa.

\section{CONCLUSIONS}

The chemotaxonomic conclusions presented here are still preliminary. Noteworthy is the chemical heterogeneity of Thysananthus convolutus, which is congruent with the morphological variation in this species, viz. the dentation of leaves, underleaves and female bracts. In other instances, however, the chemical findings do not coincide with morphology. For instance, unidentified compound $\left(\mathrm{M}^{+}\right) 302,190(100)$, 81(95) was detected in T. convolutus and in $T$. comosus sample 1 , and the unidentified $\left(\mathrm{M}^{+}\right) 320,207(100), 81(83)$ in $T$. spathulistipus sample 2 and Malaysian T. convolutus but not in other samples of these species. Furthermore, pinguisane sesquiterpenoids were only found in the morphologically very different species $T$. retusus and T. spathulistipus. The separation of Dendrolejeunea from Thysananthus was confirmed by the very different chemical composition of Dendrolejeunea fruticosa detected in this study. The results obtained in this study will be substantiated by isolation and identification of the detected unidentified compounds, which is in progress (Ludwiczuk, in prep.), and by molecular phylogenetic analysis of DNA markers and further morphological study (Sukkharak et al., submitted).

ACKNOWLEDGEMENTS. The research of the first author was supported by a Royal Thai government scholarship in cooperation with the German Academic Exchange Service (DAAD). Thanks are due to S. Chantanaorrapint for additional fresh material and field observations. 


\section{REFERENCES}

ASAKAWA Y., 1982 - Chemical constituents of the Hepaticae. In: HERZ W., GRISEBACH H. \& KIRBY G.W. (eds.), Progress in the Chemistry of Organic Natural Products, 42, Vienna, Springer, pp. 1-285.

ASAKAWA Y., 1995 - Chemical constituents of the Bryophytes. In: HERZ W., KIRBY G.W., MOORE R.E., STEGLICH W. \& TAMM C. (eds.), Progress in the Chemistry of Organic Natural Products, 65, Vienna, Springer, pp. 1-618.

ASAKAWA Y., 2004 - Chemosystematics of the Hepaticae. Phytochemistry 65: 623-669.

ASAKAWA Y., TOKUNAGA N., TAKEMOTO T., HATTORI S., MIZUTANI M. \& SUIRE C., 1980a - Chemosystematics of Bryophytes IV. Journal of the Hattori botanical laboratory 47: 153-164.

ASAKAWA Y., SUIRE C., TOYOTA M., TOKUNAGA N., TAKEMOTO T., HATTORI S. \& MIZUTANI M., 1980b - Chemosystematics of Bryophytes V. Journal of the Hattori botanical laboratory 48: 285-303.

FREY W. \& STECH M., 2009 - Marchantiophyta, Bryophyta, Anthocerotophyta. In: FREY W. (ed.), Syllabus of Plant Families. A. Engler's Syllabus der Pflanzenfamilien, 13th edition, Part 3. Bryophytes and Seedless Vascular Plants. Stuttgart, Gebr. Borntraeger Verlagsbuchhandlung, pp. 13-263.

GRADSTEIN S.R., 1975 - A taxonomic monograph of the genus Acrolejeunea (Hepaticae) with an arrangement of the genera of Ptychanthoideae. Bryophytorum bibliotheca 4: 1162.

GRADSTEIN S.R., 1992 - The genera Thysananthus, Dendrolejeunea, and Fulfordianthus gen. nov. (Studies on Lejeuneaceae subfamily Ptychanthoideae XXI). The bryologist 95: $42-51$.

GRADSTEIN S.R., 1994 - Lejeuneaceae: Ptychantheae, Brachiolejeuneae. Flora neotropica 62: 1-216.

GRADSTEIN S.R., MATSUDA R. \& ASAKAWA Y., 1981 - Oil bodies and terpenoids in Lejeuneacae and other selected Hepaticae. Journal of the Hattori botanical laboratory 50: $232-248$.

GRADSTEIN S.R., MATSUDA R. \& ASAKAWA Y., 1985 - A chemotaxonomic survey of terpenoids and aromatic compounds in the Lejeuneaceae (Hepaticae). Nova Hedwigia, Beihefte 80: 63-86. 
GRADSTEIN S.R., ASAKAWA Y., MUES R. \& KLEIN R., 1988. On the taxonomic significance of secondary metabolites in the Lejeuneaceae (Hepaticae). Journal of the Hattori botanical laboratory 64: 159-168.

GRADSTEIN S.R., HE X.-L., PIIPPO S. \& MIZUTANI M., 2002. Bryophyte flora of the Huon Peninsula, Papua New Guinea. LXVIII. Lejeuneaceae subfamily Ptychanthoideae (Hepaticae). Acta botanica Fennica 174: 1-88.

GROLLE R. \& PIIPPO S., 1984 - Annotated catalogue of Western Malesian bryophytes. I. Hepaticae and Anthocerotae. Acta botanica Fennica 125: 1-86.

HARINANTENAINA L. \& ASAKAWA Y., 2004 - Constituents of Isotachis aubertii (Isotachidaceae) collected in Madagascar. Biochemical systematics and ecology 32: 1073-1078.

HARINANTENAINA L., TAKAHARA Y., NISHIZAWA T., KOHCHI C., SOMA G.-I. \& ASAKAWA Y., 2006 - Chemical constituents of Malagasy liverwort, part V: prenyl bibenzyls and clerodane diterpenoids with nitric oxide inhibitory activity from Radula appressa and Thysananthus spathulistipus. Chemical and pharmaceutical bulletin 54: 1046-1049.

HOCHMUTH D.H., 2008 - Mass Finder 4: GC/MS Visualisation, Interpretation, and Library Administration Mass Spectral Library: Terpenoids and Related Constituents of Essential Oils, Hamburg.

JOULAIN D. \& KÖNIG W.A., 1998 - The Atlas of Spectral Data of Sesquiterpene Hydrocarbons. E.B.-Verlag, Hamburg, pp. 1-661.

KIM H.N., NITASAKA E., ODRZYKOSKI I.J. \& YAMAZAKI T., 2001 - Phylogenetic relationships among taxa of the liverwort Conocephalum conicum (Conocephalaceae) revealed by psbA sequence. Genes and genetic systems 76: 279-288.

KRUIJT R.C., NIEMANN G.J., DE KOSTER C.G. \& HEERMA W., 1986 - Flavonoids and aromatic hydroxy acids in Lejeuneaceae subfamily Ptychanthoideae (Hepaticae). Cryptogamie, Bryologie-Lichénologie 7: 165-171.

MIZUTANI M., 1961 - A revision of Japanese Lejeuneaceae. Journal of the Hattori botanical laboratory 24: 115-302.

LINSTROM P.J. \& MALLARD W.G., 2001 - The NIST Chemistry WebBook: A Chemical Data Resource on the Internet. Journal of chemical and engineering data 46: 10591063.

SPRUCE R., 1884 - Hepaticae Amazonicae et Andinae. III Lejeunea Libert. Transactions and proceedings of the botanical society of Edinburgh 15: 63-305. 
SUKKHARAK P. \& GRADSTEIN S.R., 2010a - Studies on the genus Thysananthus (Marchantiophyta: Lejeuneaceae). 1. Thysananthus discretus Sukkharak et Gradst. sp. nov. Cryptogamie, Bryologie 31: 113-119.

SUKKHARAK P. \& GRADSTEIN S.R., 2010b - On the occurrence of adnate underleaves and appendages in Thysananthus (Lejeuneaceae). Studies on the genus Thysananthus, 2. Journal of bryology 32: 308-310.

SUKKHARAK P., GRADSTEIN S.R. \& STECH M., Submitted - Phylogeny, taxon circumscriptions and chracter evolution in the core Ptychanthoideae (Lejeuneaceae, Marchantiophyta). Taxon.

SUKKHARAK P., Submitted - Monograph of Thysananthus subgenus Thysananthus (Marchantiophyta: Lejeuneaceae). Systematic Botany Monographs.

TOYOTA M., SAITOU T., MATSUNAMI J. \& ASAKAWA Y., 1997 - A comparative study on three chemo-types of the liverwort Conocephalum conicum using volatile constituents. Phytochemistry 44: 1265-1270.

THIERS B.M. \& GRADSTEIN S.R., 1989 - Lejeuneaceae (Hepaticae) of Australia. I. Subfamily Ptychanthoideae. Memoirs of the New York botanical garden 52: 1-79.

VERDOORN F., 1934 - Studien über Asiatische Jubulae. Annales bryologici, Supplement 4: 40-192.

WILSON R., GRADSTEIN S.R., SCHNEIDER H. \& HEINRICHS J., 2007 - Unravelling the phylogeny of Lejeuneaceae (Jungermanniopsida). Molecular phylogenetics and evolution 43:270-282.

WOOD W.F, LANCASTER W.C., FISHER C.O. \& STOTLER R.E., 1996 - Trans-methyl cinnamate: The major volatile from some populations of the liverwort, Conocephalum conicum. Phytochemistry 42: 241-242. 


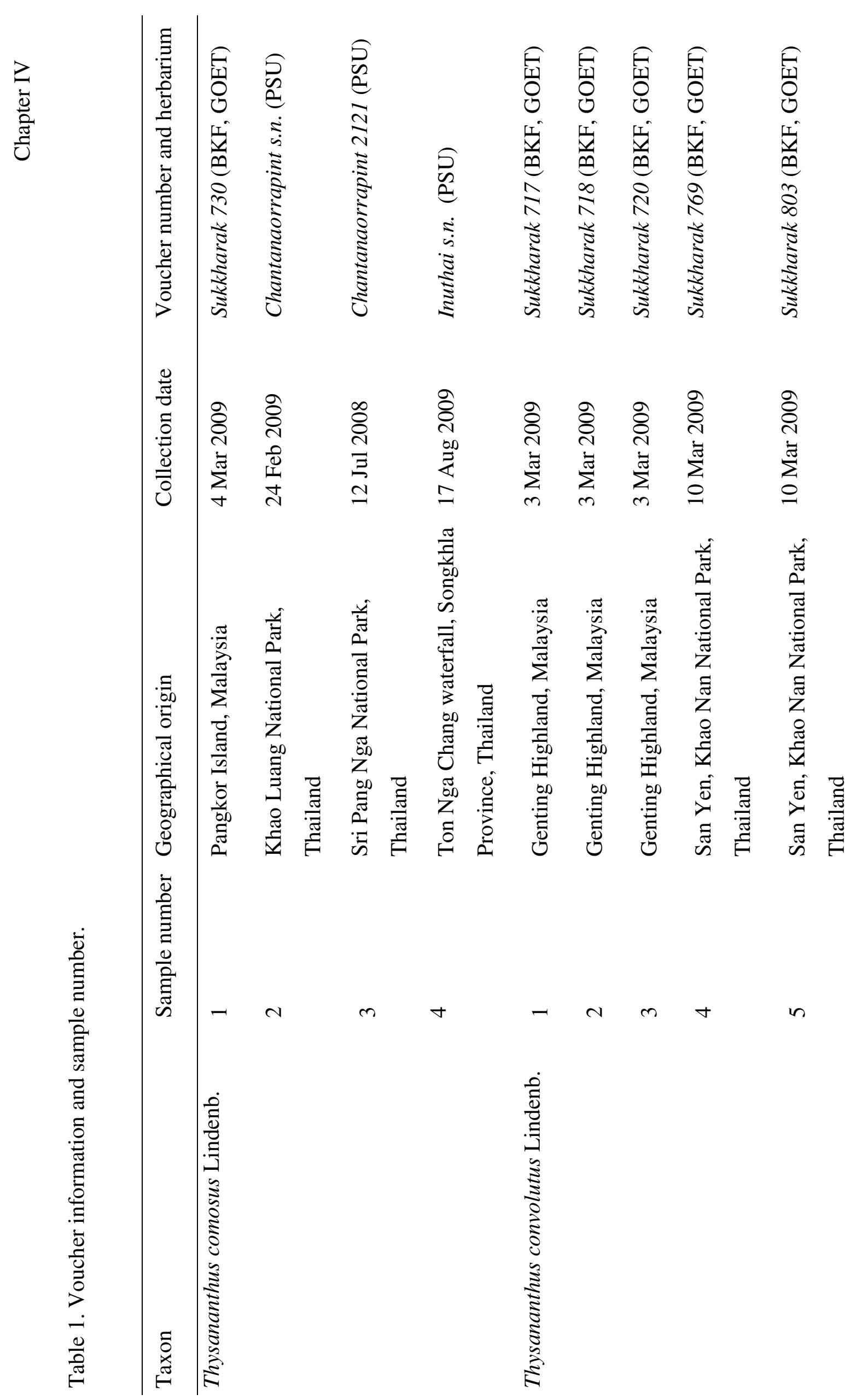




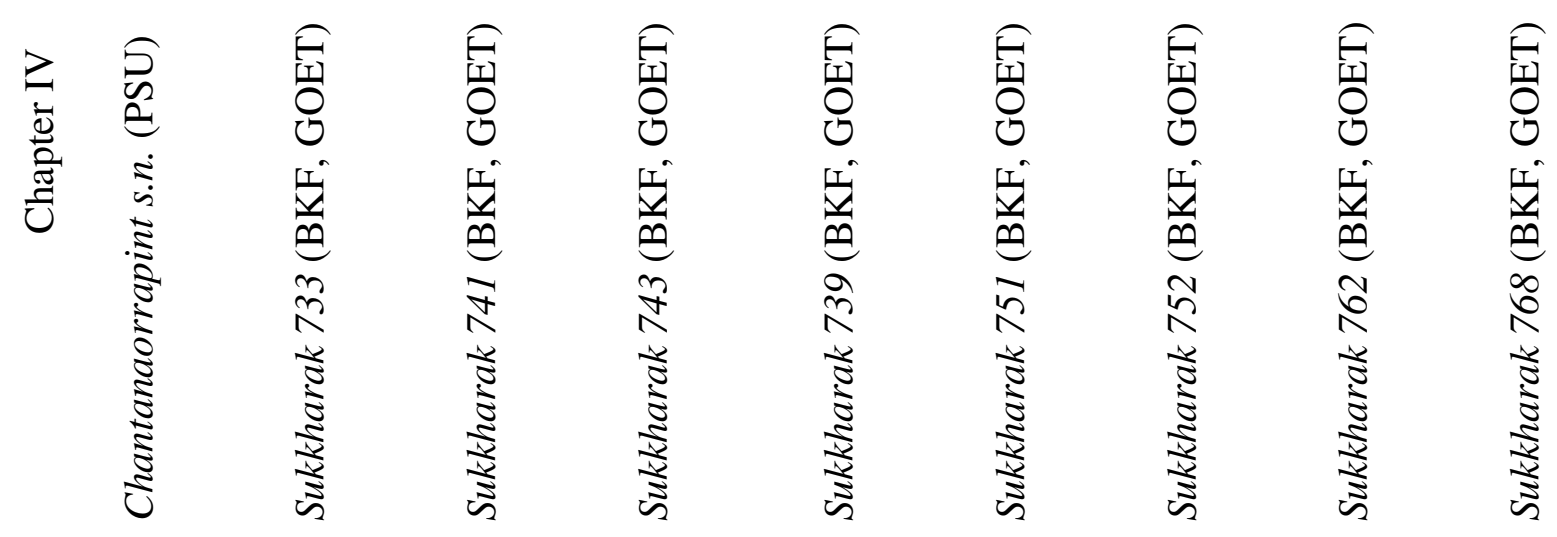

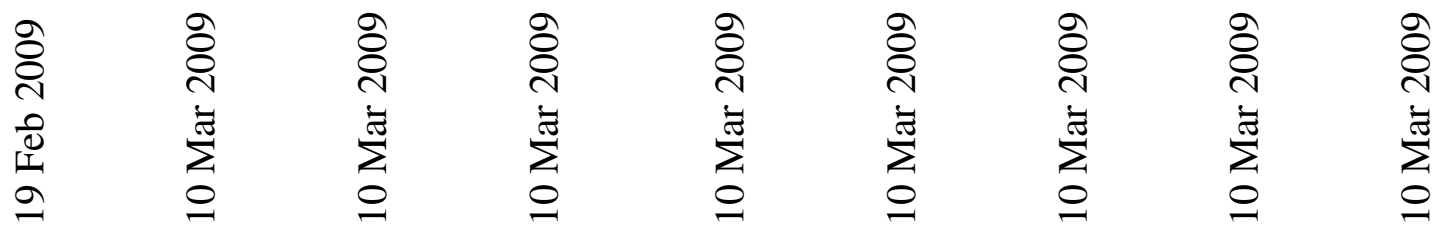

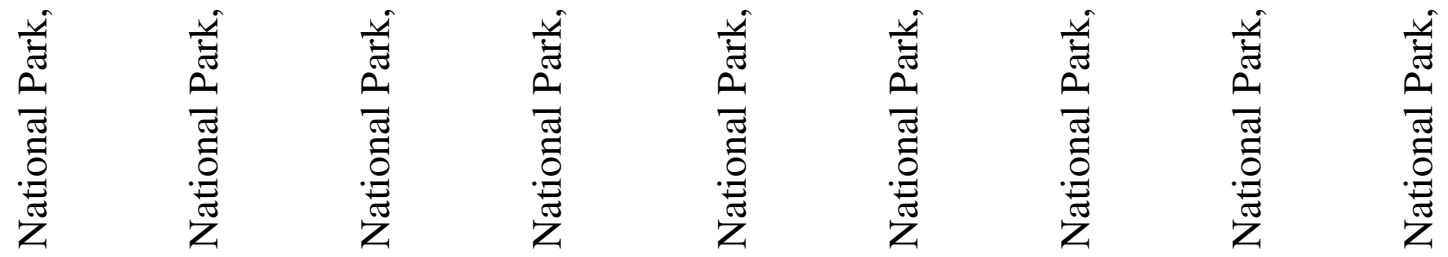

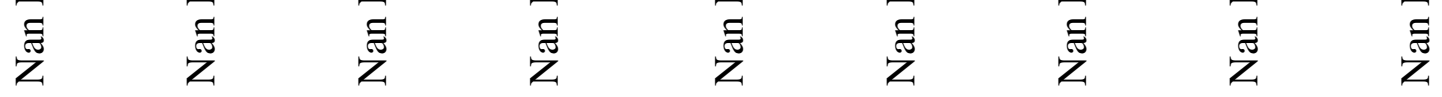

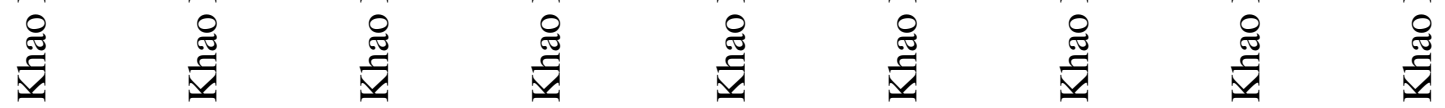

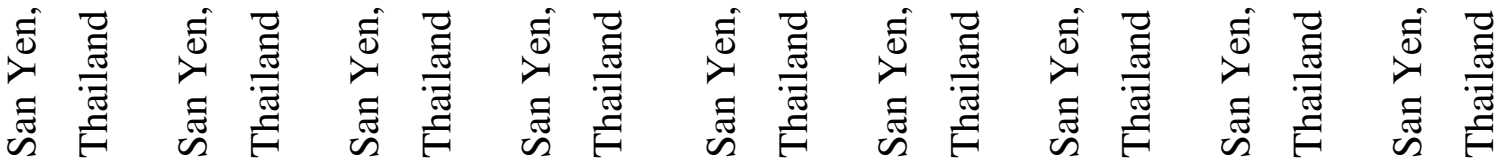

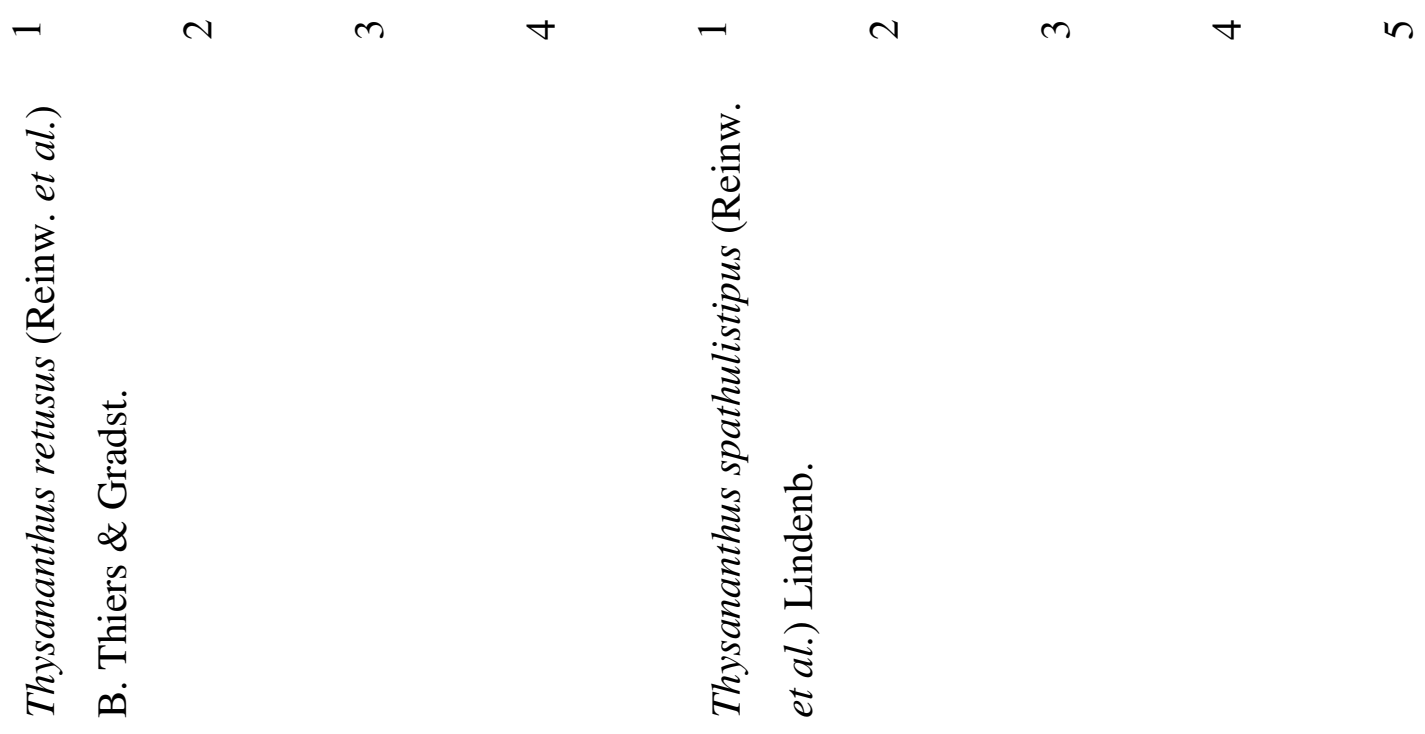




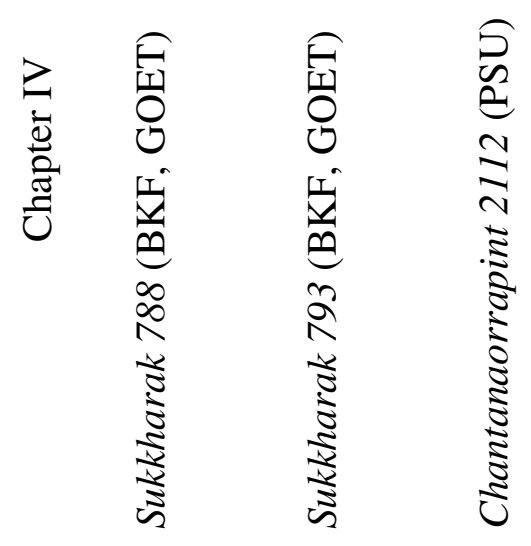

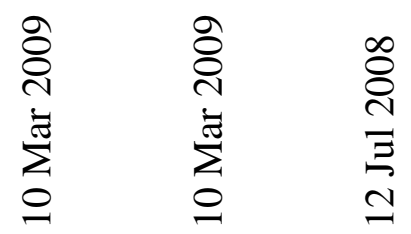

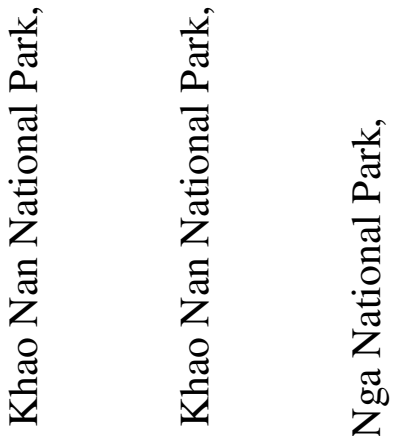

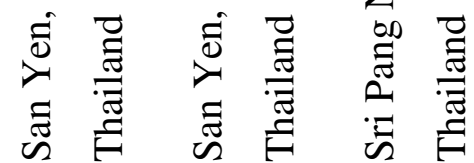

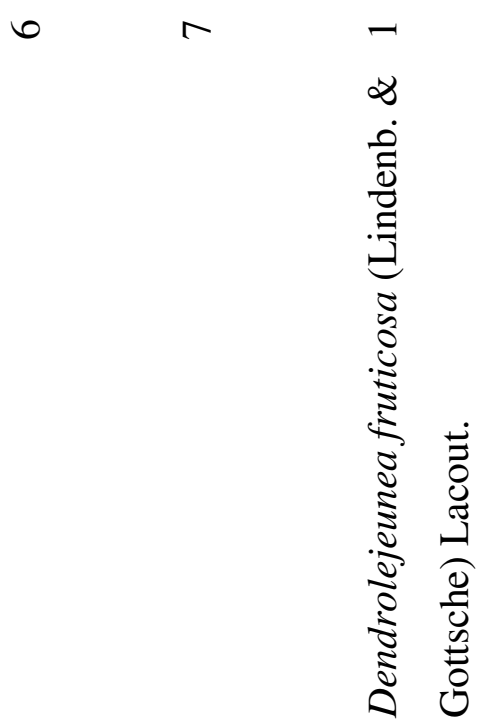




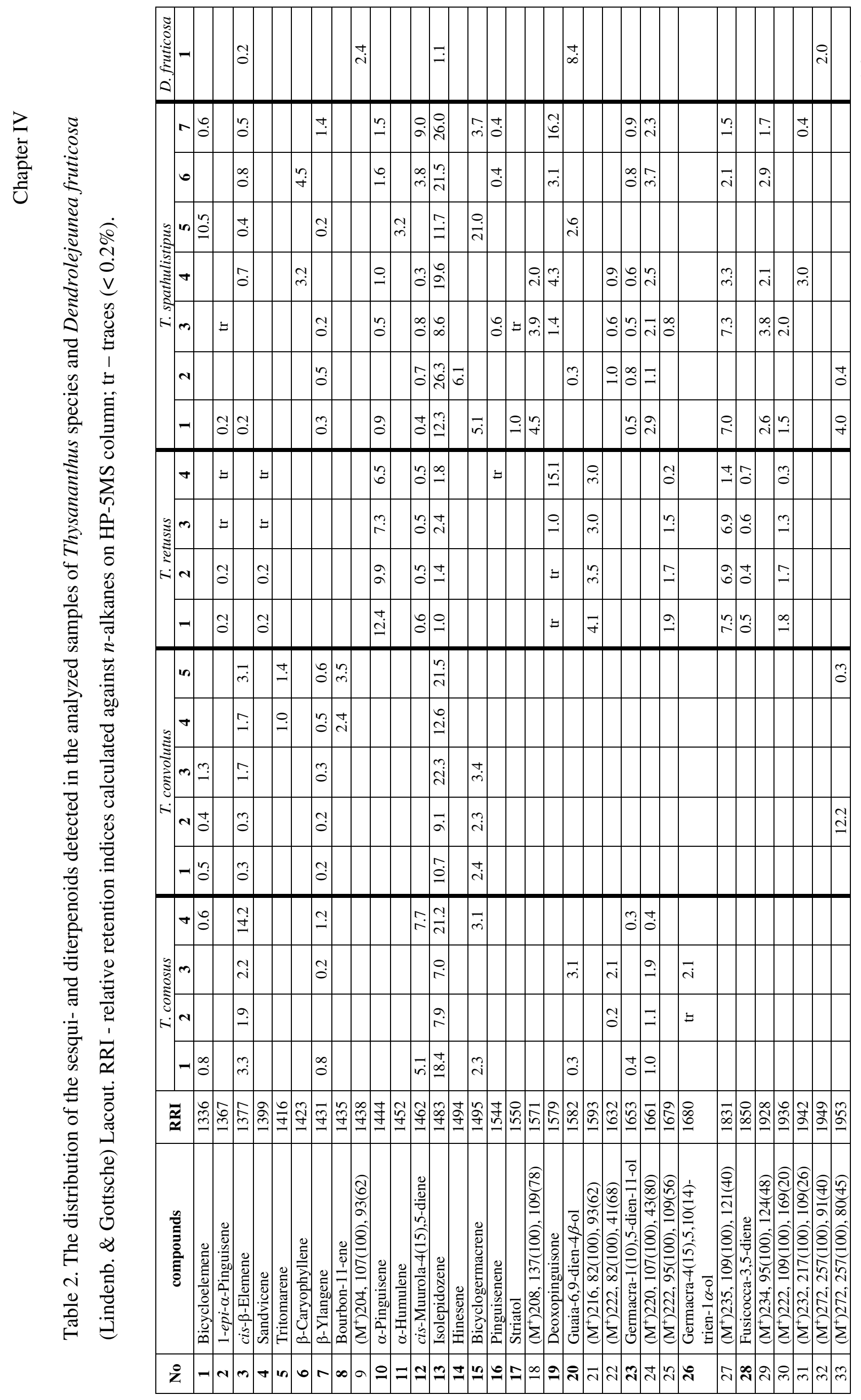




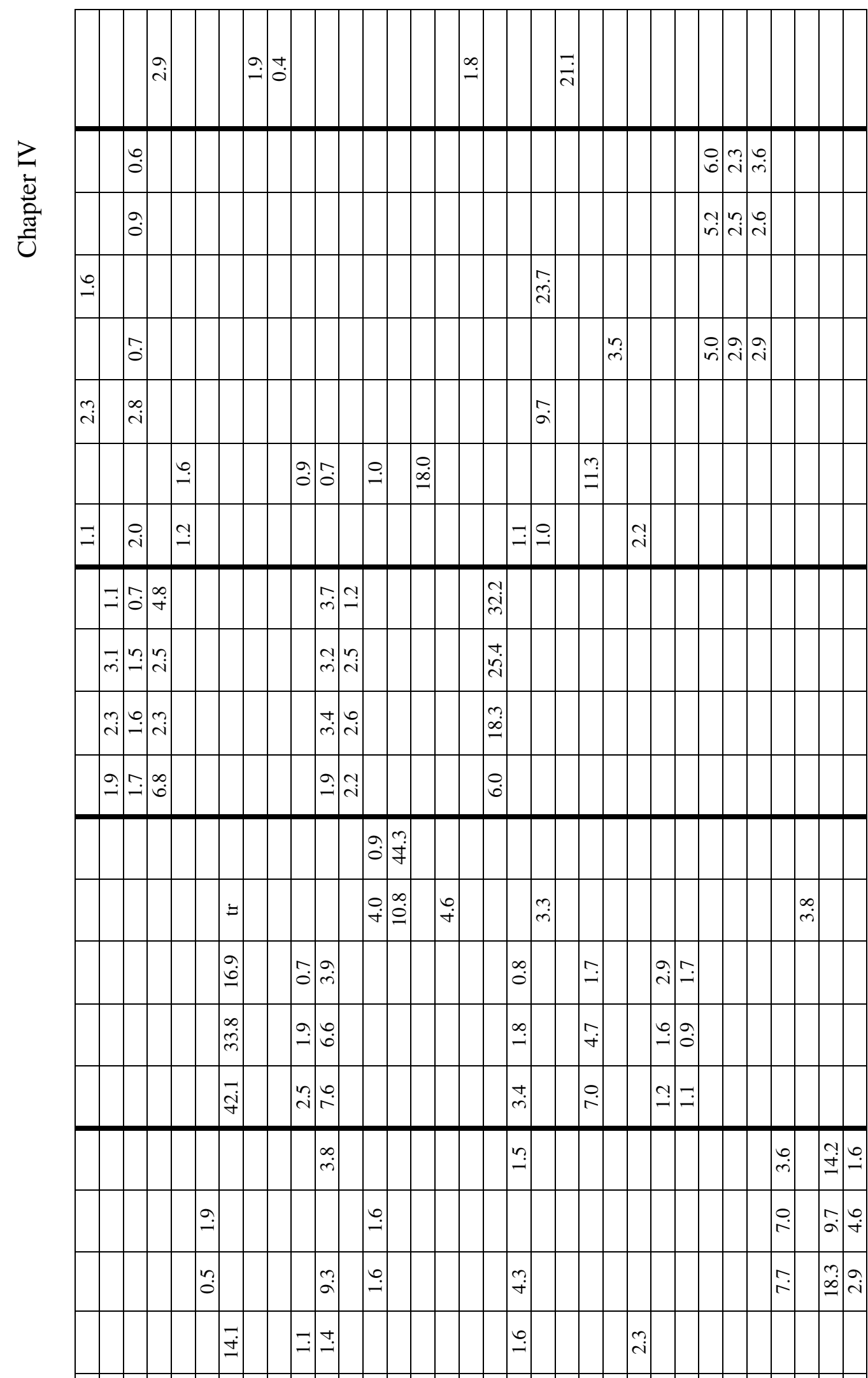

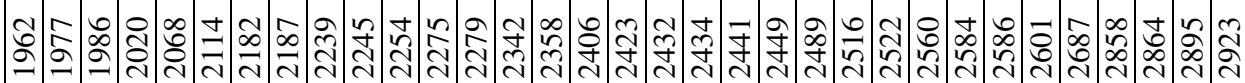

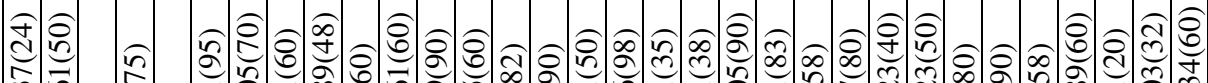

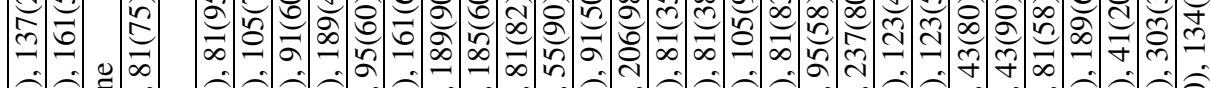

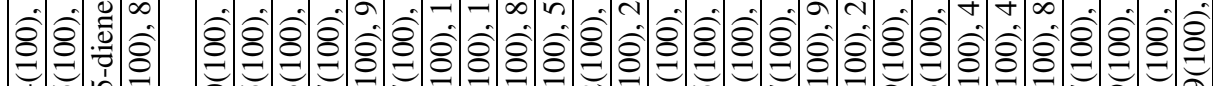
《)

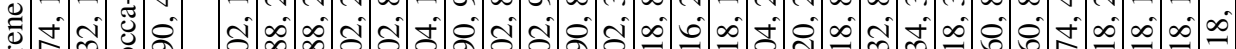

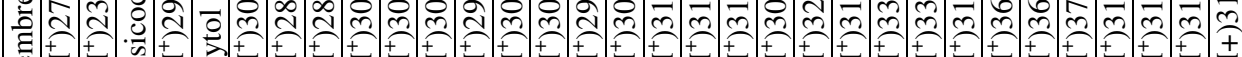

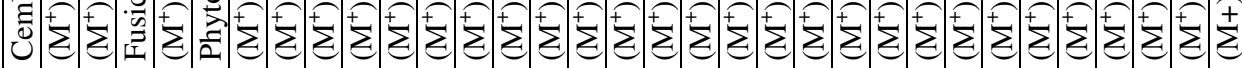

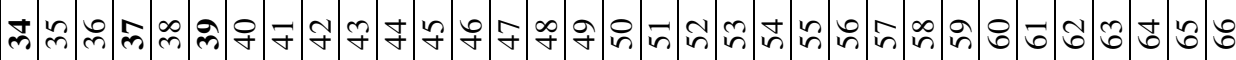




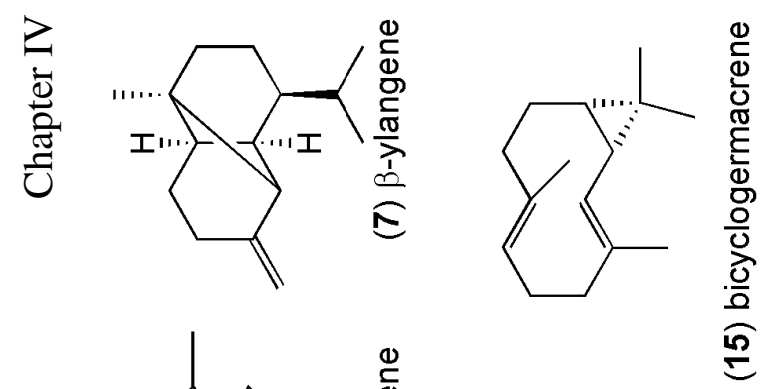
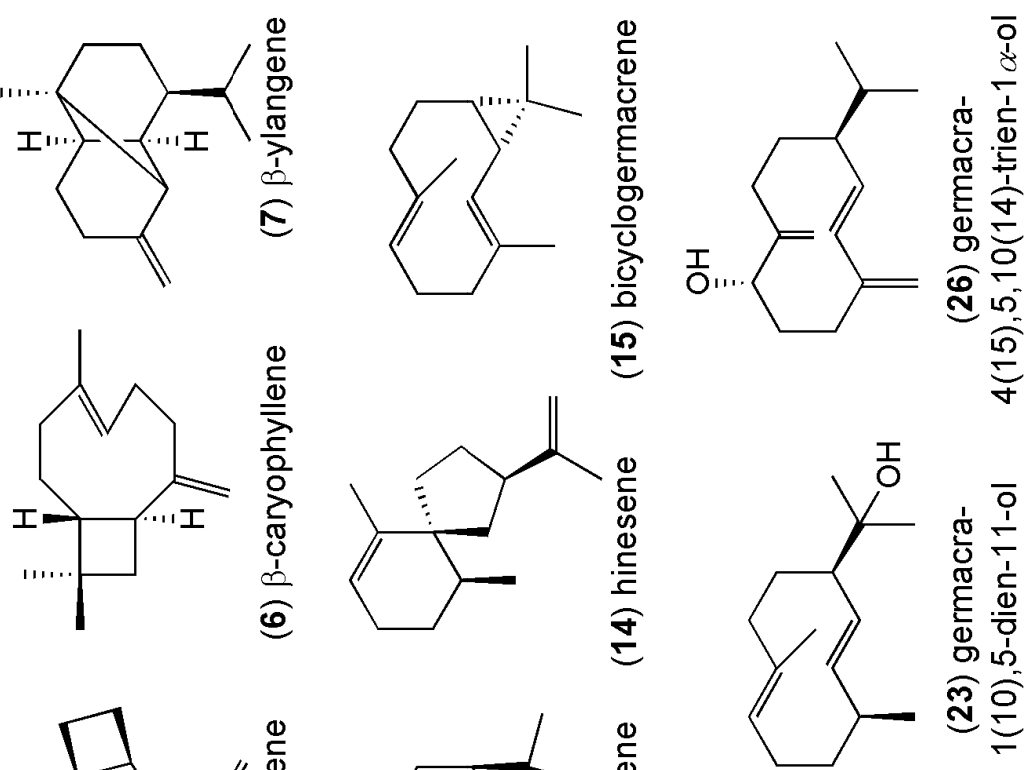

$\underbrace{}_{I}$
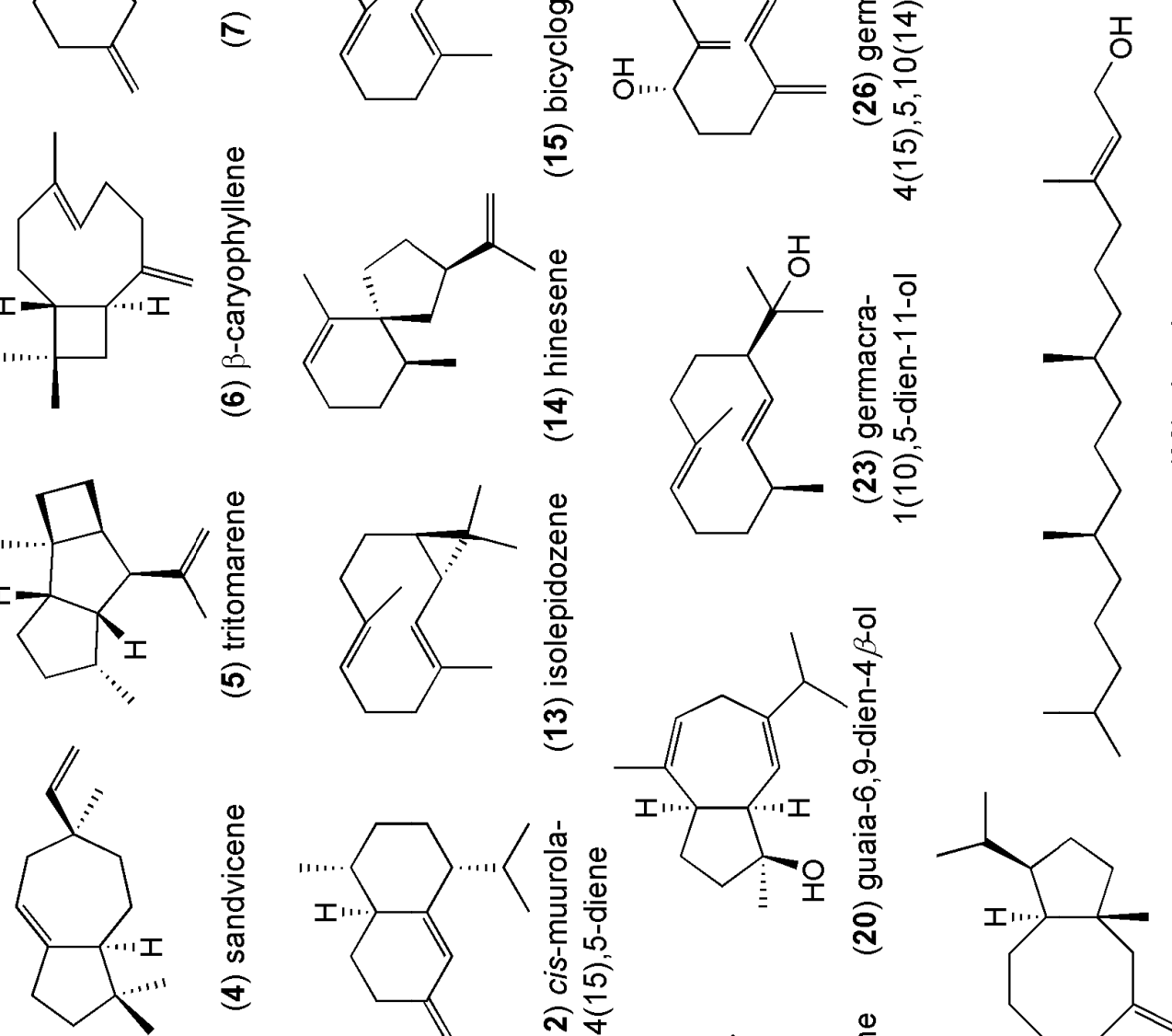

옹
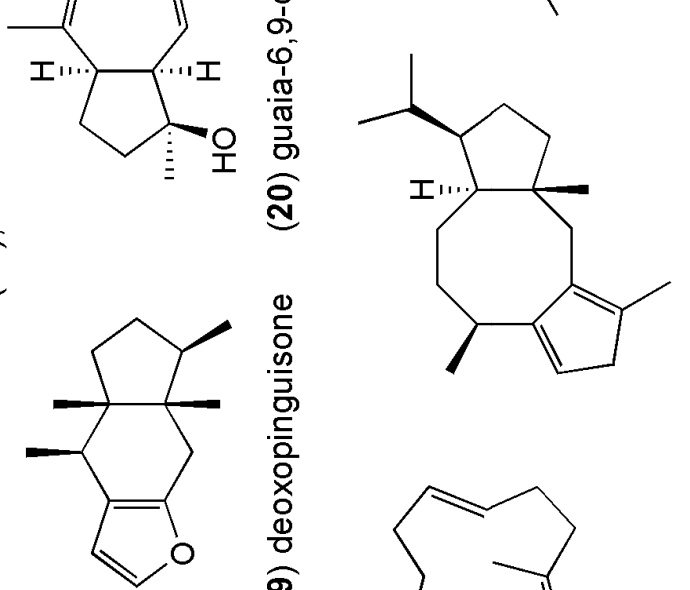

章
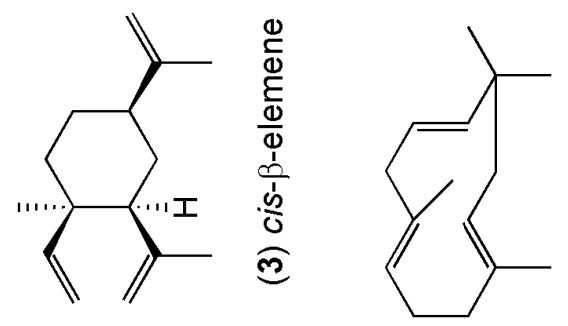

สํำ

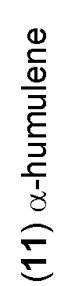
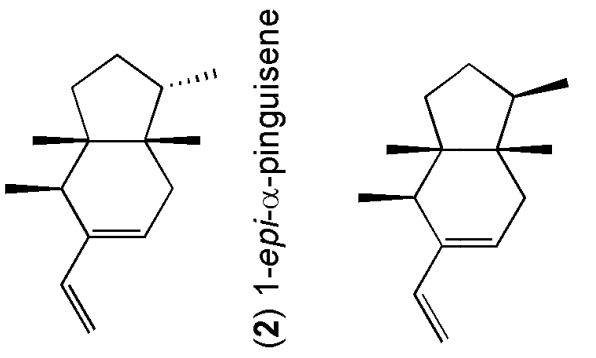

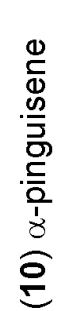
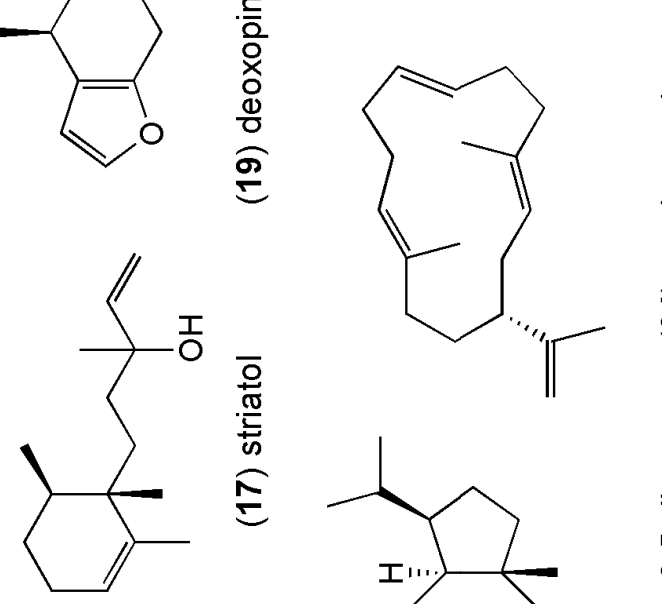

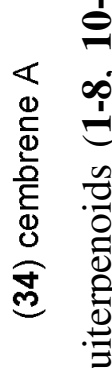

:

 (1) ह

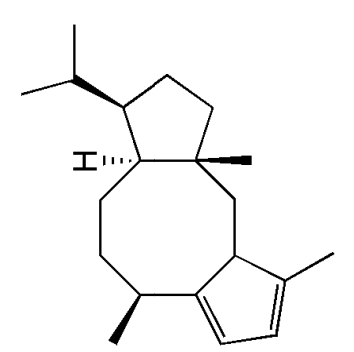

造

苟 $\stackrel{0}{\frac{0}{2}} \cdot$
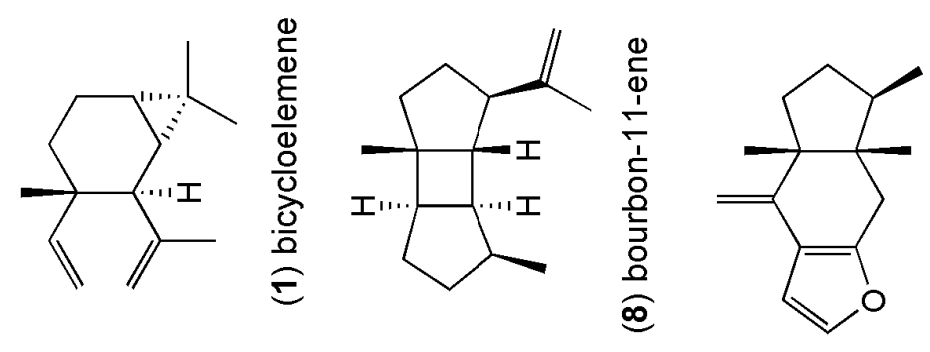

$\frac{0}{5}$
$\frac{0}{0}$
$\frac{.0}{3}$
$\frac{0}{0}$
$\frac{\overline{0}}{0}$
$\stackrel{0}{=}$

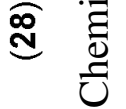




\title{
Phylogeny, taxon circumscriptions and character evolution in the core Ptychanthoideae (Marchantiophyta: Lejeuneaceae)
}

\section{Phiangphak Sukkharak ${ }^{1}$, S. Robbert Gradstein ${ }^{2}$ \& Michael Stech ${ }^{3}$}

${ }^{1}$ Department of Systematic Botany, Institute of Plant Sciences, University of Göttingen, Untere Karspüle 2, 37073 Göttingen, Germany

${ }^{2}$ Muséum National d'Histoire Naturelle, Dept. Systématique et Evolution, C.P. 39, 57 rue Cuvier, 75231 Paris cedex 05, France

${ }^{3}$ Netherlands Centre for Biodiversity Naturalis, section NHN, Leiden University, P.O. Box 9514, 2300 RA Leiden, The Netherlands

Author for correspondence: Phiangphak Sukkharak, ppsukk@gmail.com

\begin{abstract}
Phylogenetic relationships and character evolution in the core Ptychanthoideae (Lejeuneaceae, Marchantiophyta) are assessed based on molecular (plastid psbA-trnH, trnG, trnL-F, trnS-rps4, nrITS), morphological-anatomical and phytochemical data. Generic relationships are molecularly well-resolved and confirm the placement of Mastigolejeunea pancheri and the monotypic Dendrolejeunea fruticosa in Thysananthus. Most morphological characters currently used to distinguish genera in Ptychanthoideae are homoplastic according to ancestral state reconstruction. Molecular (and phytochemical) data suggest the occurrence of polyphyletic species in Thysananthus and Mastigolejeunea. However, careful study of the polyphyletic taxa revealed morphological differences between some of the intraspecific clades, which correlated with synonymized or novel species. Incongruence between plastid and ITS data in $M$. pancheri indicated the occurrence of a putative hybrid, the first one recorded in Lejeuneaceae and the first in liverworts inferred from phylogenetic data.
\end{abstract}

Keywords Character evolution; cryptic species; hybrid; Lejeuneaceae; liverworts; molecular phylogeny; Ptychanthoideae; Thysananthus

Running head: Phylogeny of the core Ptychanthoideae

Category: Molecular Phylogeny

\section{INTRODUCTION}

With about 1200 species in 78 genera (Frey \& Stech, 2009, with updates), Lejeuneaceae are by far the largest family of liverworts, and display an amazing 
morphological and ecological diversity. Lejeuneaceae are a particularly important floristic component of tropical rain forests and include many species growing epiphyllous on the leaves of rainforest trees. Diversification started in the Mid-Cretaceous according to molecular dating (Wilson \& al., 2007b, but see Yang \& Wu, 2010) and took place in the shadow of angiosperm evolution, as has also been shown for other lineages of cryptogamic plants such as ferns (Schneider \& al., 2004).

Phylogenetic reconstructions resulted in a better understanding of relationships and evolutionary patterns of major lineages within Lejeuneaceae (Gradstein \& al., 2003; Wilson \& al., 2007a, b). However, very few studies inferred phylogenetic relationships at lower taxonomic levels, aimed at clarifying species circumscriptions (Hartmann \& al., 2006; Heinrichs \& al., 2009) or the position of morphologically deviant taxa (Gradstein \& al., 2006). A particularly pressing problem is the lack of stable morphological diagnostic characters to delimit generic and infrageneric groups, despite the high overall morphological diversity (Wilson \& al., 2007a). Comprehensive molecular phylogenetic reconstructions at the inter- and intrageneric level as well as assessments of character evolution, e.g., by ancestral state reconstruction, are thus urgently needed.

This case study infers systematic relationships and character evolution in the molecularly well-supported core group of Lejeuneaceae subfamily Ptychanthoideae (Dendrolejeunea, Lopholejeunea, Mastigolejeunea, Ptychanthus, Spruceanthus, Thysananthus), with a focus on Thysananthus. The genus Thysananthus comprises eleven species (Sukkharak \& Gradstein, 2010a, with updates), all of them epiphytes in tropical rain forests and montane forests. Southeast Asia forms a centre of diversity with five species: $T$. aculeatus Herzog, T. comosus Lindenb., T. convolutus Lindenb., T. retusus (Reinw. \& al.) B. Thiers \& Gradst. and T. spathulistipus (Reinw. \& al.) Lindenb., the latter also occurring in tropical Africa. Four species are restricted to Western Melanesia (T. discretus Sukkharak \& Gradst., T. mollis Steph., T. appendiculatus Steph., T. montanus Gradst. \& al.), T. anguiformis (Hook.f. \& Taylor) Steph. is endemic to New Zealand and T. amazonicus (Spruce) Schiffn. is the only species of the genus in the New World.

Thysananthus is morphologically heterogeneous (Gradstein, 1992) and the taxonomic significance of several characters considered diagnostic of the genus is unclear. As a consequence, different generic circumscriptions and intrageneric classifications have been evoked (e.g., Verdoorn, 1934; Thiers \& Gradstein, 1989; Gradstein, 1992). For example, relationships between Thysananthus, Dendrolejeunea fruticosa (Lindenb. \& Gottsche) Lacout. and Mastigolejeunea remain unclear based on morphology alone. Molecular data support their close relationship (Wilson \& al., 2007a) but the limited sampling in the latter 
study did not allow a definite conclusion. Dendrolejeunea stands out by its dendroid habit but shares with some Thysananthus species the prominent character of having a vitta (nerf-like structure of elongate cells) in the leaves. An enlarged dorsal stem epidermis has been utilized to distinguish Mastigolejeunea from Thysananthus (Thiers \& Gradstein, 1989), which, however, does not seem to hold for all species (Hürlimann, 1991). These examples already illustrate the necessity of evaluating the phylogenetic significance of morphologicalanatomical characters in Ptychanthoideae. Besides, novel or little known morphological characters such as appendages on leaf lobules or the adnation of underleaves to leaves (Sukkharak \& Gradstein, 2010b) may improve taxon circumscriptions but their phylogenetic significance still needs to be tested.

Phylogenetic inference is often hampered by incomplete taxon sampling, caused by the difficulty of obtaining DNA sequences from old herbarium collections. In this study, however, we have been able to generate DNA sequence information from all currently recognized species of Thysananthus, covering almost the entire range of morphological variation within the genus, and from a representative species set of related genera. For the first time in Lejeuneaceae we analysed molecular data from five markers (plastid psbA-trnH, trnG, $\operatorname{trnL}-F, \operatorname{trnS}$-rps 4 , nrITS), morphological characters of all molecularly analysed specimens as well as phytochemical (terpenoid) data from selected Thysananthus species and Dendrolejeunea fruticosa comparatively in a phylogenetic framework. The principal objectives of this study are to (i) clarify generic circumscriptions and relationships within the core Ptychanthoideae, (ii) provide the first comprehensive molecular phylogeny of Thysananthus and infer inter- and intraspecific variation, and (iii) identify morphological synapomorphies for molecular clades and evaluate the phylogenetic significance and evolution of morphological characters.

\section{MATERIALS AND METHODS}

Plant material. - Selection of genera of Ptychanthoideae for molecular analysis was based on the molecular phylogenetic study of Lejeuneaceae by Wilson \& al. (2007a). A total of 46 specimens representing 26 species were sequenced, including two of Dendrolejeunea fruticosa, two of Lopholejeunea, seven of Mastigolejeunea, two of Ptychanthus striatus (Lehm. \& Lindenb.) Nees, three of Spruceanthus, 27 of Thysananthus and three of Acrolejeunea as outgroup representatives. Mastigolejeunea pancheri Steph., placed in Thysananthus by Hürlimann (1991), was maintained as a member of Mastigolejeunea because of its enlarged dorsal stem epidermis. Within Thysananthus, all eleven currently recognized species as well as different forms of variable species were sampled to represent the 
morphological variation within the genus. Ten $\operatorname{trn} L-\operatorname{trn} F$ and nine nrITS sequences were used from Wilson \& al. (2007a), all other sequences were newly generated.

DNA extraction, PCR, and sequencing. - The distal parts of shoots from fresh and herbarium specimens were thoroughly cleaned with distilled water. Total genomic DNA was extracted using the DNeasy ${ }^{\circledR}$ Plant Kit (Qiagen). Protocols for PCR were carried out as described in previous publications: psbA-trnH spacer (Sang \& al., 1997; Stech \& Frey, 2008), trnG intron (Pacak \& Szweykowska-Kulińska, 2000), trnL-F (Taberlet \& al., 1991), trnS-rps4 spacer (Nadot \& al., 1994; Souza-Chies \& al., 1997) and ITS (Stech, 2004; Hartmann \& al., 2006). When no PCR product of the whole ITS1-5.8S-ITS2 region could be obtained, ITS1 and ITS2 were amplified and sequenced separately. PCR products were purified using the Wizard ${ }^{\circledR}$ DNA Clean-up kit (Promega). Automated sequencing was performed by Macrogen Inc., Amsterdam (www.macrogen.com). Sequencing primers were those used for PCR. Vouchers related to newly sequenced specimens are deposited in BKF and GOET. Voucher information and GenBank accession numbers for all sequences used in this study are given in Appendix 1.

Alignment, sequence analysis and phylogenetic reconstructions. - DNA sequences were manually aligned in PhyDE $^{\circledR}$ v0.995 (Müller \& al., 2006). Phylogenetic reconstructions according to the maximum parsimony (MP) optimality criterion were performed using PAUP 4.0b10 (Swofford, 2002). The datasets of chloroplast regions and ITS were analysed separately. Heuristic searches under parsimony were implemented using random sequence addition with 1000 replicates and employing the default settings otherwise. Gaps were either treated as missing data or coded as informative by a simple indel coding (SIC) strategy (Simmons \& Ochoterena, 2000) as implemented in SeqState (Müller, 2004a). Heuristic bootstrap searches under parsimony were performed with 1000 replicates and 10 random addition cycles per bootstrap replicate with the same options in effect.

Posterior probabilities were calculated using MrBayes v3.1 (Huelsenbeck \& Ronquist, 2001). TVM+G was chosen as the model that best fits the data according to the AIC criterion as evaluated by MrModeltest v2.3 (Nylander, 2004) employing MrMTgui (Nuin, 2005). In a second Bayesian analysis the indels coded by SIC were included, with sequence and indel data treated as separate and unlinked partitions, employing the restriction site model ('F81') for the indel matrix. The a priori probabilities supplied were those specified in the default settings of the program. Posterior probability (PP) distributions of trees were created using the Metropolis-coupled Markov chain (MCMC) method. Four runs with four chains $\left(10^{6}\right.$ generations each) were run simultaneously, with the temperature of the single heated chain set to 0.2 . Chains were sampled every 10 generations and the respective trees written to a tree 
file. Consensus trees and posterior probabilities of clades were calculated by combining the four runs and using the trees sampled after the chains converged. Trace plots generated in Tracer v1.5 (Rambaut \& Drummond, 2007) were used to check for convergence of the runs (plateaus of all runs at comparable likelihoods) and to infer the 'burnin', which approximately ranged between the first 150,000 and 200,000 generations (first 15,000-20,000 sampled trees). Consequently, the first 25,000 trees $(25 \%)$ were deleted by default to be sure that only trees of the stationary phase were included.

Analysis of phytochemical characters. - Sixty-six terpenoids obtained from 20 specimens of Thysananthus and Dendrolejeunea fruticosa (Sukkharak \& al., in press) were included in the present study. A data matrix, which is available on request, was generated based on the presence or absence of the respective compounds in the 21 samples $(0=$ absent, 1 = present). This matrix was analysed with PAUP $4.0 \mathrm{~b} 10$ according to the maximum parsimony principle (without outgroup). Heuristic bootstrap searches under parsimony were performed with 1000 replicates and 10 random addition cycles per bootstrap replicate.

Analysis of morphological-anatomical characters and character evolution. - For each of 46 specimens for which phytochemical and/or DNA sequence data was generated, three stems from the main axis were dissected and each stem analysed at 5-10 $\mathrm{mm}$ from the apex. Both quantitative and qualitative (discrete) characters were recorded. We used 5 quantitative and 25 qualitative morphological-anatomical characters (Appendices 2-3) for phylogenetic analysis of the respective 46 specimens. Of these, 28 characters were coded as binary characters $(0 / 1)$ and two as multistate ones $(0,1$, and 2$)$. The respective character states for 'sexual condition', 'male bract lobules', 'female bract margin', 'female bracteole margin', 'perianth margin', 'number of beak cells', 'number of perianth keels' and 'subfloral innovation' could only be recorded from fertile specimens; in sterile specimens missing data was indicated by '?'. Maximum parsimony analyses were performed in PAUP 4.0b10 for (i) all 30 characters and (ii) those 22 characters that could be scored from sterile plants and were thus available from all included specimens. Heuristic bootstrap searches under parsimony were performed with 1000 replicates and 10 random addition cycles per bootstrap replicate. To search the trees pace for islands of more parsimonious trees, parsimony ratchet analyses were performed with PRAP2 (Müller, 2004b) in combination with PAUP, employing the default options (200 iterations, $25 \%$ of randomly chosen positions upweighted to 2 ) and superimposed 10 random addition cycles.

To infer patterns of character evolution, we traced the evolution of the 30 morphological characters (Appendices 2-3) over the plastid DNA phylogeny by parsimonybased ancestral state reconstruction, using Mesquite v.2.71 (Maddison \& Maddison, 2009). 
The plastid dataset was chosen because it resolved the two Mastigolejeunea pancheri samples in one clade (cf. results and discussion). The sample of Thysananthus appendiculatus was not included in the ancestral state reconstruction as no plastid sequences could be obtained. To account for topological uncertainty we used the 'trace character history' option in Mesquite.

\section{RESULTS}

Sequence characterization and alignment. - Length ranges of the sequenced markers were 179-194 nucleotides (nt) (186-194 nt within Thysananthus) for psbA-trnH spacer, 658-684 nt (647-684) for $\operatorname{trn} G$ intron, 405-435 nt (424-435) for $\operatorname{trn} L-F, 612-658 \mathrm{nt}$ (612-627) for trnS-rps4 and 950-1130 nt (950-1059) for ITS. For Mastigolejeunea pancheri sample 2 and T. appendiculatus only ITS1 could be sequenced of the ITS region.

The combined plastid alignment comprised 2077 positions (trnS-rps 4 position 1-668, trnL-F 669-1124, trnG 1125-1869, psbA-trnH 1870-2076). Of the 2077 included characters, $318(15.3 \%)$ were variable, and $218(10.5 \%$, or $68.6 \%$ of the variable positions) were parsimony-informative. Simple indel coding (SIC) yielded another 495 parsimonyinformative characters, resulting in 713 informative characters for the plastid markers in total. The ITS alignment comprised 1786 positions. The almost invariable 5.8S gene and 615 ITS positions with ambiguous alignment were excluded from phylogenetic analysis. Of the remaining 1008 included positions, 389 (38.6\%) were variable, and 271 (26.9\%, or $69.7 \%$ of the variable positions) were parsimony-informative. Inclusion of indel characters by SIC yielded another 548 parsimony-informative characters, resulting in 819 informative characters for ITS in total.

Molecular phylogenetic reconstructions. - Separate maximum parsimony analyses of the plastid versus nuclear sequence data (including indels) each retained a single most parsimonious tree (cp: length 482, CI excluding uninformative characters 0.6929, RI 0.8699, RC 0.6587; ITS: length 931, CI excluding uninformative characters 0.4856, RI 0.7428, RC 0.4157). Bayesian analyses of the plastid and ITS data resulted in the same topologies as the respective MP trees. While all trees were generally congruent with respect to well-supported clades, incongruence between the plastid and ITS analyses was observed concerning the position of Mastigolejeunea pancheri sample 2. The plastid analyses resolved both $M$. pancheri samples as a well-supported sister clade of Thysananthus anguiformis (Fig. 1), whereas in the ITS trees $M$. pancheri sample 2 was placed inside Thysananthus s.str. in a clade together with T. appendiculatus and T. discretus (Fig. 2).

All trees support a basal position of Lopholejeunea within the ingroup (Figs. 1, 2), followed by Ptychanthus striatus as sister to Spruceanthus. These clades (except 
Spruceanthus) as well as Mastigolejeunea s.str. as sister to the remainder of the ingroup receive significant support in most Bayesian and maximum parsimony analyses. Within Mastigolejeunea s.str., the samples of M. auriculata (Wils.) Schiffn. are separated into two clades. The species of Thysananthus are resolved into two major clades, which also include Dendrolejeunea fruticosa and M. pancheri. The basal split between the vittate species ( $T$. mollis, T. montanus, T. retusus, D. fruticosa) and a clade including T. anguiformis- $M$. pancheri (one or both samples, cf. above) as well as the remaining Thysananthus species ( $T$. s.str.) received significant support, whereas their sistergroup relationship is not supported. Within Thysananthus s.str., T. comosus sample 4 is resolved as basal with significant support in the ITS analyses, whereas the remaining accessions of $T$. comosus, $T$. convolutus and $T$. spathulistipus are resolved as polyphyletic.

Analysis of phytochemical characters. - The maximum parsimony calculation of the phytochemical matrix (66 characters, of which 52 were parsimony informative) yielded two trees (lengths 167, CI excluding uninformative characters 0.559, RI 0.935, RC 0.560), one of which is shown in Fig. 3. The second tree differs only in the samples T. retusus I-III being unresolved as a polytomy. The phytochemical data resolve two clades of $T$. convolutus (samples I-III and IV+V, respectively), two of $T$. spathulistipus (samples I+III and IV+VI+VII, respectively), one clade with two out of four T. comosus samples (I+II) and one clade holding all four T. retusus samples with bootstrap support $>80 \%$.

Analyses of morphological-anatomical characters and character evolution. - In the maximum parsimony analyses of morphological-anatomical characters, 10,000 trees were retained each with lengths of 100 (all 30 characters) or 77 (22 selected characters), respectively. Applying the parsimony ratchet, 153 or 102 trees were retained, with lengths of 94 (all characters) or 72 (selected characters), respectively. For all most parsimonious reconstructions the $\mathrm{CI}$ was $<0.4$, RI approx. 0.75 and $\mathrm{RC}<0.3$. The trees (not shown) were almost unresolved with a basal polytomy. Only few specimens formed distinct clades (Lopholejeunea spp., Thysananthus mollis/T. montanus, specimens of Dendrolejeunea, Ptychanthus, T. anguiformis and T. retusus), and only three of them received bootstrap support $>70 \%$ (Dendrolejeunea, Ptychanthus, T. retusus).

Parsimony-based ancestral state reconstruction of the 30 morphological-anatomical characters revealed a single state change for five characters $(1,13,16,29,30)$, viz. branch type (from Lejeunea-type to Frullania-type in Ptychanthus striatus; Fig. 4A), foliar appendages on lobule bases (present in Thysananthus mollis, T. montanus and T. retusus; Fig. 4D), vitta (present in T. mollis, T. montanus, T. retusus and Dendrolejeunea fruticosa; Fig. 4E), number of perianth keels (3 in Dendrolejeunea fruticosa, Mastigolejeunea and 
Thysananthus s.l.; Fig. 4I) and subfloral innovations (present in all ingroup taxa except Lopholejeunea; Fig. 4J). Three of these characters $(1,13,30)$ received individual RC values of 1 in the phylogenetic reconstructions, the other two had values of 0.429 and 0.438 , respectively. For character 2, also with an $\mathrm{RC}$ of 1 , two independent state changes from projecting to dendroid growth are indicated (in Ptychanthus and Dendrolejeunea; Fig. 4B), and for character 5 ( $\mathrm{RC} 0.615$ ) one change from state 1 (stem hyalodermis present) to states 0 or 2 in the ancestor of all ingroup taxa except Lopholejeunea (Fig. 4C) is inferred. For all other 23 characters at least three different state changes, including reversals, are needed to explain the patterns, as exemplarily shown for characters 20 (adnate underleaves; Fig. 4F), 25 (female bracts; Fig. 4 G) and 26 (female bracteoles; Fig. 4H).

\section{DISCUSSION}

Phylogenetic relationships, generic circumscriptions and character evolution in the core Ptychanthoideae. - The positions of Lopholejeunea, Ptychanthus striatus, Spruceanthus, Mastigolejeunea s.str. (excluding M. pancheri) and the remainder of the ingroup in our results are congruent with the molecular phylogenetic reconstructions of Lejeuneaceae by Wilson \& al. (2007a). Lopholejeunea is resolved at the base of the ingroup. It is distinguished from the other genera by a combination of character states including dark pigmentation of cell walls, a discrete hyalodermis (Fig. 4C), strongly inflated-gibbose lobules, absence of subfloral innovations (Fig. 4J), and perianths with 4-5 sharp, dentate-laciniate (rarely entire) keels (Fig. 4I). Most of these character states, however, occur also in the outgroup (stem hyalodermis, absence of subfloral innovations) or in other clades of the ingroup (e.g., toothed perianth margins in Thysananthus s.1.). Synapomorphic character states for Lopholejeunea are missing.

Ptychanthus striatus is resolved as sister to Spruceanthus from which it differs morphologically by Frullania-type branching (Fig. 4A), dendroid habit (Fig. 4B), presence of auricles at underleaf bases, and elongate leaf cells. Similar to Lopholejeunea, most of these character states occur in other core Ptychanthoideae taxa as well, except for Frullania-type branching. No morphological synapomorphies could be detected for the PtychanthusSpruceanthus clade.

Mastigolejeunea is traditionally characterised by the enlarged dorsal stem epidermis, separating it from Thysananthus which has epidermal cells as large as medulla cells (Thiers \& Gradstein, 1989). Our results (Fig. 4C) revealed that the enlarged epidermis stem evolved at least twice, in Mastigolejeunea s.str. and in the M. pancheri-T. anguiformis clade. 
Mastigolejeunea s.str. can at the moment only be unambiguously characterised based on molecular sequence data.

Thysananthus also includes Dendrolejeunea fruticosa and Mastigolejeunea pancheri according to the molecular phylogenetic reconstructions (Figs. 1, 2). The frequently changing placement of D. fruticosa, either in Dendrolejeunea (Spruce, 1884; Lacouture, 1908; Gradstein, 1992) or in Thysananthus (Schiffner, 1893; Verdoorn, 1934; Thiers \& Gradstein, 1989) reflects an obvious uncertainty about the systematic value of morphological characters, in particular the growth habit. Thysananthus shares with most other Ptychanthoideae the ancestral state of projecting growth and irregularly pinnate branches (Fig. 4B), whereas Dendrolejeunea stands out by its dendroid habit, having creeping stoloniform stems and upright, regularly pinnate branches. Dendroid growth, however, developed independently in Ptychanthus striatus (Fig. 4B). The clade of D. fruticosa, T. mollis, T. montanus and T. retusus, in contrast, is easily recognized by the presence of a vitta as a synapomorphic character state (Fig. 4E), and corresponds to one of the three Thysananthus sections (sect. Vittatae) by Verdoorn (1934). Besides, D. fruticosa shares with all Thysananthus species the character state of 3 perianth keels (Fig. 4I). Consequently, D. fruticosa is treated as a member of Thysananthus (T. fruticosus (Lindenb. \& Gottsche) Schiffn.) in the light of the present molecular data and character state reconstructions. Thysananthus fruticosus and the other vittate species in the genus ( $T$. mollis, T. montanus, $T$. retusus) can be regarded as morphologically advanced, the former due to its dendroid growth and the latter because of the presence of foliar appendages on lobule bases (Fig. 4D).

In contrast to Thysananthus fruticosus, Mastigolejeunea pancheri has always been separated from Thysananthus by its entire female involucres and enlarged dorsal epidermis in stem cross-section (Thiers \& Gradstein, 1989; but see Hürlimann, 1991). Our results, however, reveal that these characters are not suitable to separate $M$. pancheri from Thysananthus, and confirm the placement of M. pancheri in Thysananthus by Hürlimann (1991), as T. pancheri (Steph.) Hürl. In accordance with traditional usage and Figures 1-4, the species is referred to as M. pancheri in this paper. The molecularly well-supported sistergroup relationship of the $T$. anguiformis-M. pancheri and Thysananthus s.str. clades is supported by the presence of adnate underleaves (Fig. 4F). In its current circumscription, synapomorphic character states for Thysananthus are missing.

'Cryptic' species in Thysananthus and Mastigolejeunea. - Within Thysananthus s.str., T. comosus, T. convolutus and T. spathulistipus were resolved as polyphyletic. This result seems to indicate a higher genetic than morphological variation, resulting in cryptic speciation which is increasingly being demonstrated in bryophytes (e.g., Shaw, 2000; Shaw \& 
Allen, 2000; Feldberg \& al., 2004, 2010; Stech \& Dohrmann, 2004; Stech \& Wagner, 2005; Heinrichs \& al., 2009, 2010; Kreier \& al., 2010). However, morphological scrutiny of the samples of the "polyphyletic" species revealed that some of the intraspecific molecular clades fitted with formerly recognized species treated as synonyms, or with novel taxa. For example, T. convolutus samples 2 and 5 were resolved in a well-supported clade separate from other $T$. convolutus samples. This separation is reflected in the morphology, samples 2 and 5 having entire instead of toothed leaves. Plants of T. convolutus with entire or toothed leaves are also separated phytochemically (Fig. 3). The samples with entire leaves fit with the formerly recognized T. gottschei (Jack \& Steph.) Steph., which was reduced to synonymy under $T$. convolutus and considered the edentate form of the latter (Grolle \& Piippo, 1984). Our molecular results, however, indicate that $T$. gottschei should be re-instated at the species level.

A similar case is seen in the sister genus Mastigolejeunea. Accessions of $M$. auriculata (Wils.) Schiffn. from Malaysia (sample 1) and southern USA (sample 2) were not in the same clade, which was also observed by Wilson \& al. (2007a) based on specimens from Indonesia and Bolivia. The molecular evidence of Wilson \& al. (2007a) and the present study suggests that the Asiatic and neotropical populations of $M$. auriculata represent different taxa. The plants from Malaysia and Indonesia have rather short, broad and flat leaves, a transverse lobule apex not or shortly continuing into the ventral lobe margin, and curved flagelliform branches on the older portions of the stem. Leaves of the plants from USA and Bolivia, in contrast, are much more elongate and strongly convex to subsquarrose, the lobule apex is oblique and longly continuing into the ventral lobe margin, and flagelliform branches are absent. In addition, perianths of Asiatic plants are large and the ventral keels are as large as the lateral keels, in contrast to much smaller perianths with ventral keels much less pronounced than the lateral ones in the neotropical plants. The Asian populations of $M$. auriculata were originally described as M. humilis (Gottsche) Schiffn.; later taxonomic work (e.g., Gradstein \& Inoue, 1980) suggested that M. humilis cannot be sharply separated morphologically from $M$. auriculata, described from the Neotropics. Our molecular results, however, clearly support the recognition of the Asiatic M. humilis as a separate species.

Thysananthus comosus sample 4, which was also sequenced by Wilson \& al. (2007a), is separated from other accessions of T. comosus in the present analyses. Morphological reexamination of this specimen shows that it differs from typical T. comosus by its enlarged dorsal epidermis, entire leaves and underleaves, elongate lobule teeth 4-6 cells long (0-2 cells long in typical T. comosus), and underleaf bases only occasionally connate with leaves. Thysananthus comosus sample 4 shares several characters with the other Thysananthus s.str. taxa (toothed female involucres and perianths) and with the T. anguiformis-M. pancheri clade 
(stem with enlarged dorsal epidermis), which supports its position in the molecular trees as an evolutionary link between these two groups. Elongate lobule teeth 4-6 cells long, in contrast, possibly evolved independently in $T$. comosus sample 4 and in $T$. retusus according to the phylogenetic reconstructions. The unique combination of morphological character states of $T$. comosus sample 4 clearly supports its separation from the remaining specimens in the molecular phylogenetic reconstructions. Consequently, this specimen should be described as a new species (Sukkharak, submitted).

The phytochemical data indicate further intraspecific variation in T. comosus, since samples I+II are resolved in a well-supported clade separated from samples III+IV (Fig. 3). Samples I+II originate from inland forest habitats, whereas sample III was collected from rock in coastal forest, and sample IV grew near a torrential waterfall. The different chemical composition of samples III+IV might thus possibly be due to stress induced by salt spray or the harsh aquatic environment, respectively. Similar environmental effects on chemical composition have been reported from other liverwort species (cf. Asakawa, 1995; Harinantenaina \& Asakawa, 2004). Whether the two phytochemical and ecological types of $T$. comosus groups represent different genotypes needs to be tested with molecular data.

\section{Hybridization in bryophytes and the first example in Lejeuneaceae. -} Phylogenies constructed from the nuclear ribosomal ITS and plastid sequence data were incongruent concerning the placement of Mastigolejeunea pancheri sample 2. In the cpDNA phylogeny (Fig. 1), M. pancheri sample 2 is sister to M. pancheri sample 1, and both samples are placed in a well-supported clade with T. anguiformis. In contrast, in the nuclear ITS tree (Fig. 2), M. pancheri sample 2 is sister to the T. appendiculatus-T. discretus clade with significant support. As M. pancheri is morphologically well separated from T. appendiculatus and T. discretus (e.g., by the enlarged stem epidermis; Fig. 4C), the ITS phylogeny is probably the deviating one, whereas the plastid phylogeny concurs with the current species circumscription. Mastigolejeunea pancheri sample 2 is morphologically most similar to $M$. pancheri sample 1, but differs from the latter by larger plants (70-75 $\mathrm{mm}$ wide in contrast to 48-57 $\mathrm{mm}$ in M. pancheri sample 1).

Incongruent gene phylogenies can either reflect complex phylogenetic patterns or simply highlight methodological or stochastic errors, or poorly supported data (Wendel \& Doyle, 1998; McBreen \& Lockhart, 2006; Frajman \& al., 2007; Harris, 2008; Rautenberg \& al., 2008). Sequencing errors can be rejected as a cause of the incongruence in M. pancheri, as the sequences were verified by repeated DNA extractions as well as multiple PCR and sequencing reactions. Besides, the incongruence is obviously not a result of different analysis 
methods, since the same pattern was found with significant support in both MP and Bayesian reconstructions.

Biological processes leading to incongruent gene phylogenies are manifold and include both intra-lineage (e.g., mistaken orthology due to gene duplications) and interlineage events, such as incomplete lineage sorting of alleles, or homo- or polyploid hybridization (e.g., Wendel \& Doyle, 1998; Rautenberg \& al., 2008). Distinguishing between these phenomena is difficult based on phylogenetic evidence alone (e.g., Gómez-Zurita \& Vogler, 2006; Harris, 2008). One way to decide between incomplete lineage sorting or hybridization is to compare the divergence times of the conflicting nodes (Rautenberg $\&$ al., 2008). If the age of the respective node is older in the organismal tree than in the deviating one, incomplete lineage sorting can be rejected and hybridization accepted. The single dated phylogeny of Lejeuneaceae (Wilson \& al., 2007b) includes only few representatives of Thysananthus and Mastigolejeunea, however, we can hypothesize that the position of $M$. pancheri sample 2 in the plastid tree concerns an older node than its position in the ITS tree. The split of T. anguiformis and Thysananthus s.str. was dated c. 17 Mya (Wilson \& al., 2007b), whereas the common ancestor of T. convolutus and T. spathulistipus in their study (corresponding to T. convolutus sample 4 and T. spathulistipus sample 5 in the present study) is dated c. 3 Mya. The clade of T. appendiculatus and T. discretus must then be even younger, which would also hold for M. pancheri sample 2 if the ITS tree would represent the organismal phylogeny. Together with the larger plant size, these considerations provide first evidence that $M$. pancheri sample 2 is probably of hybrid origin. Given the maternal inheritance of plastids in bryophytes, $M$. pancheri should be considered the maternal parent of M. pancheri sample 2, whereas either T. appendiculatus or T. discretus is probably the paternal parent of the hybrid. However, further analyses including chromosome counts are necessary to test the hybridization hypothesis and to determine possible polyploidy of $M$. pancheri sample 2. Inference from a more detailed dated phylogeny of Ptychanthoideae may confirm the putative young age of the hybridization event.

Hybridization is a major factor leading to phylogenetic incongruence among different datasets in angiosperms (Mason-Gamer \& Kellogg, 1996; Nishimoto \& al., 2003; Winkworth \& Donoghue, 2005; McBreen \& Lockhart, 2006; Kim \& Donoghue, 2008). In bryophytes, several molecular studies based on allozyme data reported (putative) hybridization in mixed populations of related species, and hybrid speciation via allopolyploidy. Most cases were observed in the moss families Sphagnaceae (peatmosses) (e.g., Cronberg, 1996; Cronberg \& Natcheva, 2002; Såstad \& al., 1999, 2000), Bryaceae (Shaw, 1994), Mniaceae (e.g., Wyatt \& al., 1992, 1993a, 1993b) and Polytrichaceae (Derda \& Wyatt, 2000), but there are also reports 
from liverwort families, viz. Pelliaceae (Odrzykoski \& al., 1996), Aytoniaceae (BoisselierDubayle \& al., 1996), Plagiochilaceae (Newton, 1986) and Porellaceae (Boisselier-Dubayle \& al., 1998).

Incongruence between phylogenies based on DNA sequences have been observed much more rarely in bryophytes, and usually concern plastid versus nuclear ribosomal DNA. Again, cases were found in the moss families Sphagnaceae (Shaw \& Goffinet, 2000; Shaw \& al., 2005), and Mniaceae (Harris, 2008), but also in Funariaceae (McDaniel \& al., 2009). The case of Plagiomnium medium (B.S.G.) Kop. (Harris, 2008; Wyatt \& al., 1988) might be comparable with $M$. pancheri: the hybrid origin of $P$. medium was reflected by its incongruent placement as sister to $P$. insigne (Mitt.) Kop. (plastid data) versus $P$. ellipticum (Brid.) Kop. (nuclear data), the former species probably representing the maternal parent of $P$. medium, based on plastid DNA restriction fragment patterns (Wyatt \& al., 1988).

Our findings in Mastigolejeunea pancheri constitute the first report of a putative hybrid in Lejeuneaceae, the largest liverwort family, and the first case of putative hybridization in the liverworts inferred from incongruence of plastid versus nuclear data.

\section{CONCLUSIONS}

The new molecular evidence has provided a solid basis for inferring systematic relationships and taxon circumscriptions in the core Ptychanthoideae, and for determining the phylogenetic significance of morphological-anatomical characters in this group. The generally high molecular variability of non-coding DNA markers in liverworts (e.g., Quandt \& Stech, 2005) provides sufficient variation for well-resolved and supported phylogenetic reconstructions, which are generally congruent between the employed plastid markers and nrITS except in the putative hybrid specimen of $M$. pancheri. As a general pattern, the genera of the core Ptychanthoideae are characterised more clearly by molecular data than by morphological characters. Only five character states were resolved as synapomorphic for single clades by ancestral state reconstruction (Frullania-type branching, appendages on lobule bases, presence of a vitta, 3-keeled perianths, presence of subfloral innovations; Fig. 4). In contrast, the majority of morphological characters traditionally used to distinguish between genera in Ptychanthoideae (Gradstein, 1994), including leaf characters such as leaf position, leaf shape and dentation of leaf margins, are homoplastic to different degrees. Our results indicate that genera within Ptychanthoideae may be distinguished by a combination of molecular data and non-exclusive morphological-anatomical character states. Recent evidence, furthermore, indicates that a search for new morphological characters may be worthwhile. For example, adnate underleaves are very rare in the order Porellales 
(Frullaniaceae, Lejeuneaceae, Porellaceae, etc.) but were recently shown to be a common feature in Thysananthus (Sukkharak \& Gradstein, 2010b; Fig. 4F). The presence of appendages at lobule bases is another example of a phylogenetically significant new morphological characters (Sukkharak \& Gradstein, 2010b), being resolved as synapomorphic for the T. mollis-T. montanus-T. retusus clade (Fig. 4D).

At the intraspecific level, the present study revealed high molecular diversity within Thysananthus, which is in accordance with the results of a growing number of molecular studies of liverworts and mosses (see above). In Thysananthus, however, this intraspecific diversity appeared to be less 'cryptic' than in other bryophyte taxa, as some molecular clades fitted quite well with novel or synonymized taxa recognized previously as separate species. The molecular evidence was effective in the resurrection of these synonyms as separate species. Again, a combination of molecular and morphological data appears most effective to clearly delimit such taxa. Similar to the liverwort genera Plagiochila (e.g., Heinrichs \& al., 2000, 2004; Rycroft \& al., 2004) and Radula (Figueiredo \& al., 2009; Stech \& al., 2010), phytochemical data also appear to be of some taxonomic value in Lejeuneaceae and may contribute as a third independent dataset, which needs to be further evaluated.

\section{ACKNOWLEDGEMENTS}

The research of the first author was supported by a Royal Thai government scholarship in cooperation with the German Academic Exchange Service (DAAD). We thank C. Gehrig-Downie and S. Chantanaorrapint for additional fresh material. Thanks are also due to M.C.M. Eurlings and the staff of DNAmarkerpoint (Leiden University) for technical assistance and to J.-P. Frahm, I. Haerida, T. Hallingbäck, B.C. Ho, S. Kornochalert, T. Peng, R.P. Shi, Y.M. Wei and R.-L. Zhu for photographs.

\section{LITERATURE CITED}

Asakawa, Y. 1995. Chemical constituents of the Bryophytes. Pp. 1-618 in: Herz, W., Kirby, W.B., Moore, R.E., Steglich, W. \& Tamm, C. (eds.), Progress in the chemistry of organic natural products. 65 . Vienna: Springer.

Boisselier-Dubayle, M.C., Lambourdiere, J. \& Bischler, H. 1996. Progeny analysis by isozyme markers in the polyploid liverwort Plagiochasma rupestre. Canad. J. Bot. 74: $521-527$.

Boisselier-Dubayle, M.C., Lambourdiere, J. \& Bischler, H. 1998. The leafy liverwort Porella baueri (Porellaceae) is an allopolyploid. Pl. Syst. Evol. 210: 175-197. 
Cronberg, N. 1996. Isozyme evidence of relationships within Sphagnum sect. Acutifolia (Sphagnaceae, Bryophyta). Pl. Syst. Evol. 203: 41-64.

Cronberg, N. \& Natcheva, R. 2002. Hybridization between the peat mosses, Sphagnum capillifolium and S. quinquefarium (Sphagnaceae, Bryophyta) as inferred by morphological characters and isozyme markers. Pl. Syst. Evol. 234: 53-70.

Derda, G.S. \& Wyatt, R. 2000. Isozyme evidence regarding the origins of three allopolypoid species of Polytrichastrum (Polytrichaceae, Bryophyta). Pl. Syst. Evol. 220: 37-53.

Feldberg, K., Groth, H., Wilson, R., Schäfer-Verwimp, J. \& Heinrichs, J. 2004. Cryptic speciation in Herbertus (Herbertaceae, Jungermanniopsida): range and morphology of Herbertus sendtneri inferred from nrITS sequences. Pl. Syst. Evol. 249: 247-261.

Feldberg, K., Váňa, J., Long, D.G., Shaw, A.J., Hentschel, J. \& Heinrichs, J. 2010. A phylogeny of Adelanthaceae (Jungermanniales, Marchantiophyta) based on nuclear and chloroplast DNA markers, with comments on classification, cryptic speciation and biogeography. Molec. Phylog. Evol. 55: 293-304.

Figueiredo, A.C., Sim-Sim, M., Barroso, J.G., Pedro, L.G., Esquível, M.G., Fontinha, S., Luis, L., Martins, S. \& Stech, M. 2009. Liverwort Radula species from Portugal: chemotaxonomical evaluation of volatiles composition. Flavour Fragr. J. 24: 316325.

Frajman, B. \& Oxelman, B. 2007. Reticulate phylogenetics and phytogeographical structure of Heliosperma (Sileneae, Caryophyllaceae) inferred from chloroplast and nuclear DNA sequences. Molec. Phylog. Evol. 43: 140-155.

Frey, W. \& Stech, M. 2009. Marchantiophyta, Bryophyta, Anthocerotophyta. Pp. 13-263 in: Frey, W. (ed.), Syllabus of plant families. A. Engler's Syllabus der Pflanzenfamilien, 13th ed., part 3, Bryophytes and seedless vascular plants. Stuttgart: Schweizerbart.

Gómez-Zurita, J. \& Vogler, A.P. 2006. Testing introgressive hybridization hypotheses using statistical network analysis of nuclear and cytoplasmic haplotypes in the leaf beetle Timarcha goettingensis species complex. J. Molec. Evol. 62: 421-433.

Gradstein, S.R. 1992. The genera Thysananthus, Dendrolejeunea, and Fulfordianthus gen. nov. (Studies on Lejeuneaceae subfamily Ptychanthoideae XXI). Bryologist 95: 4251.

Gradstein, S.R. 1994. Lejeuneaceae: Ptychantheae, Brachiolejeunea. Fl. Neotrop. Monogr. 62: 1-216.

Gradstein, S.R. \& Inoue, H. 1980. Studies on Lejeuneaceae subfam. Ptychanthoideae, V. A review of the species from Ceylon. Bull. Natl. Sci. Mus., Tokyo, B. 6: 23-32. 
Gradstein, S.R., Reiner-Drehwald, M.E. \& Schneider, H. 2003. A phylogenetic analysis of the genera of Lejeuneaceae (Hepaticae). Bot. J. Linn. Soc. 143: 391-410.

Gradstein, S.R., Wilson, R., Ilkiu-Borges, A.L. \& Heinrichs, J. 2006. Phylogenetic relationships and neotenic evolution of Metzgeriopsis (Lejeuneaceae) based on chloroplast DNA sequences and morphology. Bot. J. Linn. Soc. 151: 293-308.

Grolle, R. \& Piippo, S. 1984. Annotated catalogue of Western Malesian bryophytes. I Hepaticae and Anthocerotae. Acta Bot. Fenn. 125: 1-86.

Harinantenaina, L. \& Asakawa, Y. 2004. Constituents of Isotachis aubertii (Isotachidaceae) collected in Madagascar. Biochem. Syst. Ecol. 32: 1073-1078.

Harris, E.S.J. 2008. Paraphyly and multiple causes of phylogenetic incongruence in the moss genus Plagiomnium (Mniaceae). Taxon 57: 417-433.

Hartmann, F.A., Wilson, R., Gradstein, S.R., Schneider, H. \& Heinrichs, J. 2006. Testing hypotheses on species delimitations and disjunctions in the liverwort Bryopteris (Jungermanniopsida: Lejeuneaceae). Int. J. Pl. Sci. 167: 1205-1214.

Heinrichs, J., Anton, H., Gradstein, S.R. \& Mues, R. 2000. Systematics of Plagiochila sect. Glaucescentes Carl (Hepaticae): a morphological and chemotaxonomical approach. Pl. Syst. Evol. 220: 115-138.

Heinrichs, J., Groth, H., Lindner, M., Feldberg, K. \& Rycroft, D.S. 2004. Molecular, morphological and phytochemical evidence for a broad species concept of Plagiochila bifaria (Sw.) Lindenb. (Hepaticae). Bryologist 107: 28-40.

Heinrichs, J., Kugmann, F., Hentschel, J. \& Schneider, H. 2009. DNA taxonomy, cryptic speciation and diversification of the Neotropical-African liverwort, Marchesinia brachiata (Lejeuneaceae, Porellales). Molec. Phylog. Evol. 53: 113-121.

Heinrichs, J., Hentschel, J., Bombosch, A., Fiebig, A., Reise, J., Edelmann, M., Kreier, H.P., Schäfer-Verwimp, A., Caspari, S., Schmidt, A.R., Zhu, R.-L., von Konrat, M., Shaw, B. \& Shaw, A.J. 2010. One species or at least eight? Delimitation and distribution of Frullania tamarisci (L.) Dumort. s. 1. (Jungermanniopsida, Porellales) inferred from nuclear and chloroplast DNA markers. Molec. Phylog. Evol. 56: 11051114.

Huelsenbeck, J.P. \& Ronquist, F. 2001. MrBayes: Bayesian inference of phylogenetic trees. Bioinformatics 17: 754-755.

Hürlimann, H. 1989. Hepaticae aus dem Gebiete des südlichen Pazific X. Bauhinia 9: 153170. 
Kim, S.-T. \& Donoghue, M.J. 2008. Incongruence between cpDNA and nrITS tress indicates extensive hybridization within Eupersicaria (Polygonaceae). Amer. J. Bot. 95: 1122-1135.

Kreier, H.P., Feldberg, K., Mahr, F., Bombosch, A., Schmidt, A.R., Zhu, R.-L., von Konrat, M., Shaw, B., Shaw, A.J. \& Heinrichs, J. 2010. Phylogeny of the leafy liverwort Ptilidium: cryptic speciation and shared haplotypes between the Northern and Southern Hemispheres. Molec. Phylog. Evol. 57: 1260-1267.

Lacouture, C. 1908. Clé analytique et synoptique des quarante et quelques sous-genres de l'ancien Lejeunea (Libert). Rev. Bryol. 35: 101-114.

Maddison, W.P. \& Maddison, D.R. 2009. Mesquite: a modular system for evolutionary analysis. Version 2.71. http://mesquiteproject.org.

Mason-Gamer, R.J. \& Kellogg, E.A. 1996. Testing for phylogenetic conflict among molecular datasets in the tribe Triticeae (Gramineae). Syst. Biol. 45: 524-545.

McBreen, K. \& Lockhart, P.J. 2006. Reconstructing reticulate evolutionary histories of plants. Trends Pl. Sci. 11: 398-404.

McDaniel, S.F., von Stackelberg, M., Richardt, S., Quatrano, R.S., Reski, R. \& Rensing, S.A. 2009. The speciation history of the Physcomitrium-Physcomitrella species complex. Evolution 64: 217-231.

Müller, K. 2004a. SeqState - primer design and sequence statistics for phylogenetic DNA data sets. Appl. Bioinformatics 4: 65-69.

Müller, K. 2004b. PRAP - computation of Bremer support for large data sets. Molec. Phylog. Evol. 31: 780-782.

Müller, K., Müller, J., Neinhuis, C. \& Quandt, D. 2006. PhyDE - Phylogenetic data editor, v0.995. Program distributed by the authors. www.phyde.de.

Nadot, S., Bajon, R., Lejeune, B. 1994. The chloroplast gene rps4 as a tool for the study of Poaceae phylogeny. Pl. Syst. Evol. 191: 27-38.

Newton, M.E. 1986. Bryophyte phylogeny in terms of chromosome cytology. J. Bryol. 14: $43-57$.

Nishimoto, Y., Ohnishi, O. \& Hasegawa, M. 2003. Topology incongruence between nuclear and chloroplast DNA tress suggesting hybridization in the Urophyllum group of the genus Fagopyrum (Polygonaceae). Genes Genet. Syst. 78: 139-153.

Nuin, P.A.S. 2005. MTgui - a simple interface to ModelTest. Program distributed by the author. University of Toronto. www.genedrift.org/mtgui.php.

Nylander, J.A.A. 2004. MrModeltest v2. Program distributed by the author, Evolutionary Biology Centre, Uppsala University. 
Odrzykoski, I.J., Chudszinska, E. \& Szweykowski, J. 1996. The hybrid origin of the polyploid liverwort Pellia borealis. Genetica 98: 75-86.

Pacak, A. \& Szweykowska-Kulińska, Z. 2000. Molecular data concerning the allopolyploid character and the origin of chloroplast and mitochondrial genomes in the liverwort species Pellia borealis. J. Pl. Biotechnol. 2: 101-108.

Quandt, D. \& Stech, M. 2005. Molecular evolution and secondary structure of the chloroplast trnL intron in bryophytes. Molec. Phylog. Evol. 36: 429-443.

Rambaut, A. \& Drummond, A.J. 2007. Tracer v1.4. http://beast.bio.ed.ac.uk/Tracer (v1.5 released 30-11-2009).

Rautenberg, A., Filatov, D., Svennblad, B., Heidari, N. \& Oxelman, B. 2008. Conflicting phylogenetic signals in the SIX1/Y1 gene in Silene. BMC Evol. Biol. 8: 299. DOI: 10.1186/1471-2148-8-299.

Rycroft, D.S., Groth, H. \& Heinrichs, J. 2004. Reinstatement of Plagiochila maderensis (Jungermanniopsida: Plagiochilaceae) based on chemical evidence and nrDNA ITS sequences. J. Bryol. 26: 37-45.

Sang, T., Crawford, D. \& Stuessy, T.F. 1997. Chloroplast DNA phylogeny, reticulate evolution, and biogeography of Paeonia (Paeoniaceae). Amer. J. Bot. 84: 1120-1136.

Såstad, S.M., Flatberg, K.I. \& Cronberg, N. 1999. Electrophoretic evidence supporting a theory of allopolyploid origin of Sphagnum jensenii. Nord. J. Bot. 19: 355-362.

Såstad, S.M., Flatberg, K.I. \& Hanssen, L. 2000. Origin, taxonomy and genetic structure of the allopolyploid peat moss Sphagnum majus. Pl. Syst. Evol. 225: 73-84.

Schiffner, V. 1893. Hepaticae. Pp. 3-263 in: Engler, A. \& Prantl, K. (eds.), Die natürlichen Pflanzenfamilien 1, 3. Leipzig: Engelmann.

Schneider, H., Schuettpelz, E., Pryer, K.M., Cranfill, R., Magallon, S. \& Lupia, R. 2004. Ferns diversified in the shadow of angiosperms. Nature 428: 553-557.

Shaw, A.J. 1994. Systematics of Mielichhoferia (Bryaceae: Musci). III. Hybridization between Mielichhoferia elongata and M. mielichhoferiana. Amer. J. Bot. 81: 782-790.

Shaw, A.J. 2000. Molecular phylogeography and cryptic speciation in the mosses, Mielichhoferia elongata and M. mielichhoferiana (Bryaceae). Molec. Ecol. 9: 595608.

Shaw, A.J. \& Allen, B. 2000. Phylogenetic relationships, morphological incongruence, and geographic speciation in the Fontinalaceae (Bryophyta). Molec. Phylog. Evol. 16: 225-237.

Shaw, A.J. \& Goffinet, B. 2000. Molecular evidence of reticulate evolution in peatmosses (Sphagnum), including S. echyalinum sp. nov. Bryologist 103: 357-374. 
Shaw, A.J., Cox, C.J. \& Boles, S.B. 2005. Phylogeny, species delimitation, and recombination in Sphagnum section Acutifolia. Syst. Bot. 30: 16-33.

Simmons, M.P. \& Ochoterena, H. 2000. Gaps as characters in sequence-based phylogenetic analyses. Syst. Biol. 49: 369-381.

Souza-Chies, T.T., Bittar, G., Nadot, S., Carter, L., Besin, E. \& Lejeune, B. 1997. Phylogenetic analysis ofin Iridaceae with parsimony and distance methods using the plastid gene rps4. Pl. Syst. Evol. 204: 109-123.

Spruce, R. 1884. Lejeunea subgenus Dendro-lejeunea. In: Hepaticae Amazonicae et Andinae. Trans. Proc. Bot. Soc. Edinburgh 15: 110-111.

Stech, M. 2004. Supraspecific circumscription and classification of Campylopus (Dicranaceae, Bryopsida) based on inferences from sequence data. Syst. Bot. 29: 817824.

Stech, M \& Dohrmann, J. 2004. Molecular relationships and biogeography of two Gondwanan Campylopus species, C. pilifer and C. introflexus (Dicranaceae). Monogr. Syst. Bot. Missouri Bot. Gard. 98: 415-431.

Stech, M. \& Frey, W. 2008. A morpho-molecular classification of the mosses (Bryophyta). Nova Hedwigia 85: 1-21.

Stech, M., Sim-Sim, M., Esquível, M.G., Luís, L., Fontinha, S., Lobo C., Garcia, C., Martins, S., Vieira, C., Barroso, J., Pedro, L.G. \& Figueiredo, A.C.S. 2010. Molecular, phytochemical and morphological characterization of the liverwort genus Radula in Portugal (mainland, Madeira, Azores). Syst. Biodiv. 8: 257-268.

Stech, M. \& Wagner, D. 2005. Molecular relationships, biogeography, and evolution of Gondwanan Campylopus species (Dicranaceae, Bryopsida). Taxon 54: 377-382.

Sukkharak, P. \& Gradstein, S.R. 2010a. Studies on the genus Thysananthus (Marchantiophyta: Lejeuneaceae). 1. Thysananthus discretus Sukkharak et Gradst. sp. nov. Cryptog. Bryol. 31: 113-119.

Sukkharak, P. \& Gradstein, S.R. 2010b. On the occurrence of adnate underleaves and appendages in Thysananthus (Lejeuneaceae). Studies on the genus Thysananthus, 2. J. Bryol. 32: 308-310.

Sukkharak, P., Ludwiczuk, A., Asakawa, Y. \& Gradstein, S.R. In press. Studies on the genus Thysananthus (Marchantiophyta, Lejeuneaceae) 3. Terpenoid chemistry and chemotaxonomy of selected species of Thysananthus and Dendrolejeunea fruticosa. Cryptog. Bryol.

Sukkharak, P. Submitted. Monograph of Thysananthus subgenus Thysananthus (Marchantiophyta: Lejeuneaceae). Syst. Bot. Monogr. 
Swofford, D.L. 2002. PAUP*: Phylogenetic analysis using parsimony (*and other methods) version 4.0b10. Sinauer Associates Inc., Sunderland, MA.

Taberlet, P., Gielly, L., Pautou, G. \& Bouver, J. 1991. Universal primers for amplification of three non-coding regions of chloroplast DNA. Pl. Mol. Biol. 17: 1105-1109.

Thiers, B.M. \& Gradstein, S.R. 1989. Lejeuneaceae (Hepaticae) of Australia. I. Subfamily Ptychanthoideae. Mem. New York Bot. Gard. 52: 1-79.

Verdoorn, F. 1934. Studien über Asiatische Jubulae. Ann. Bryol. Suppl. 4: 40-192.

Wendel, J.F. \& Doyle, J.J. 1998. Phylogenetic incongruence: Window into genome history and molecular evolution. Pp. 265-296 in: Soltis, D.E., Soltis, P.S. \& Doyle, J.J. (eds.), Molecular systematic of plants II: DNA sequencing. New York: Chapman \& Hall.

Wilson, R., Gradstein, S.R., Schneider, H. \& Heinrichs, J. 2007a. Unravelling the phylogeny of Lejeuneaceae (Jungermanniopsida). Molec. Phylog. Evol. 43: 270-282.

Wilson, R., Heinrichs, J., Hentschel, J., Gradstein, S.R. \& Schneider, H. 2007b. Steady diversification of derived liverworts under Tertiary climatic fluctuations. Biol. Lett. 3: $566-569$.

Winkworth, R.C. \& Donoghue, M.J. 2005. Viburnum phylogeny based on combined molecular data: implications for taxonomy and biogeography. Amer. J. Bot. 92: 653666.

Wyatt, R., Odrzykoski, I.J., Stoneburner, A., Bass, H.W. \& Galau, G.A. 1988. Allopolyploidy in bryophytes: multiple origins of Plagiomnium medium. Proc. Natl. Acad. Sci. U.S.A. 85: 5601-5604.

Wyatt, R., Odrzykoski, I.J. \& Stoneburner, A. 1992. Isozyme evidence of reticulate evolution in mosses: Plagiomnium medium is an allopolyploid of P. ellipticum $x P$. insigne. Syst. Bot. 17: 532-550.

Wyatt, R., Odrzykoski, I.J. \& Stoneburner, A. 1993a. Isozyme evidence regarding the orgins of the allopolyploid moss Plagiomnium curvatulum. Lindbergia 18: 49-58.

Wyatt, R., Odrzykoski, I.J. \& Stoneburner, A. 1993b. Isozyme evidence proves that the moss Rhizomnium pseudopunctatum is an allopolyploid of $R$. gracile $x R$. magnifolium. Mem. Torrey Bot. Club 25: 21-35.

Yang, X.J. \& Wu, X.W. 2010. Sinolejeunea yimaensis gen. et sp. nov. (Hepaticae) from the Middle Jurassic Yima Formation in Henan Province of China. Sci. China Earth Sci. 54: 228-232. DOI: 10.1007/s11430-010-4153-2. 
BPP, BPPSIC, MPB \& MPBSIC $\geq 95$

BPP \& BPPSIC $\geq 95$, either MPB or MPBSIC $\geq 95$

BPP \& BPPSIC $\geq 95$, MPB \& MPBSIC $>70$

BPP \& BPPSIC $\geq 95$, either MPB or MPBSIC $>70$
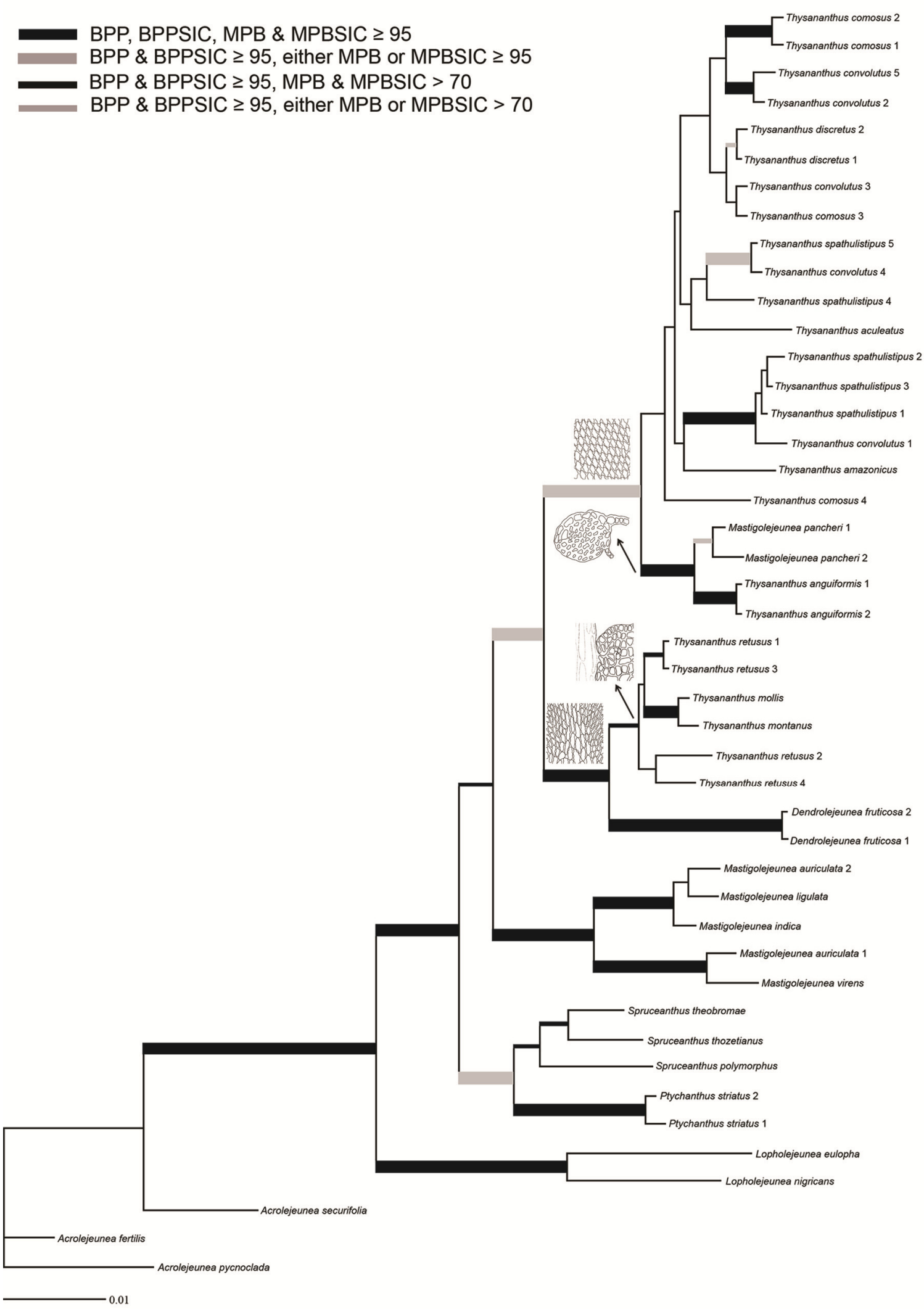

Fig. 1. Majority rule Bayesian phylogram inferred from the combined chloroplast dataset including differences in sequence lengths (indels). Branch thickness and color indicate bootstrap support and posterior probability values. BPP $=$ posterior probability values from Bayesian analysis, in which gaps treated as missing data; BPPSIC = posterior probability values from Bayesian analysis, in which gaps treated as informative by a simple indel coding strategy; MPB = bootstrap support values from the maximum parsimony optimality criterion, in which gaps treated as missing data; MPBSIC = bootstrap support values from the maximum parsimony optimality criterion, in which gaps treated as informative by a simple indel coding strategy. For further explanation see text. 
Chapter V

BPP, BPPSIC, MPB \& MPBSIC $\geq 95$

BPP \& BPPSIC $\geq 95$, either MPB or MPBSIC $\geq 95$

BPP \& BPPSIC $\geq 95$, MPB \& MPBSIC $>70$

BPP \& BPPSIC $\geq 95$, either MPB or MPBSIC $>70$

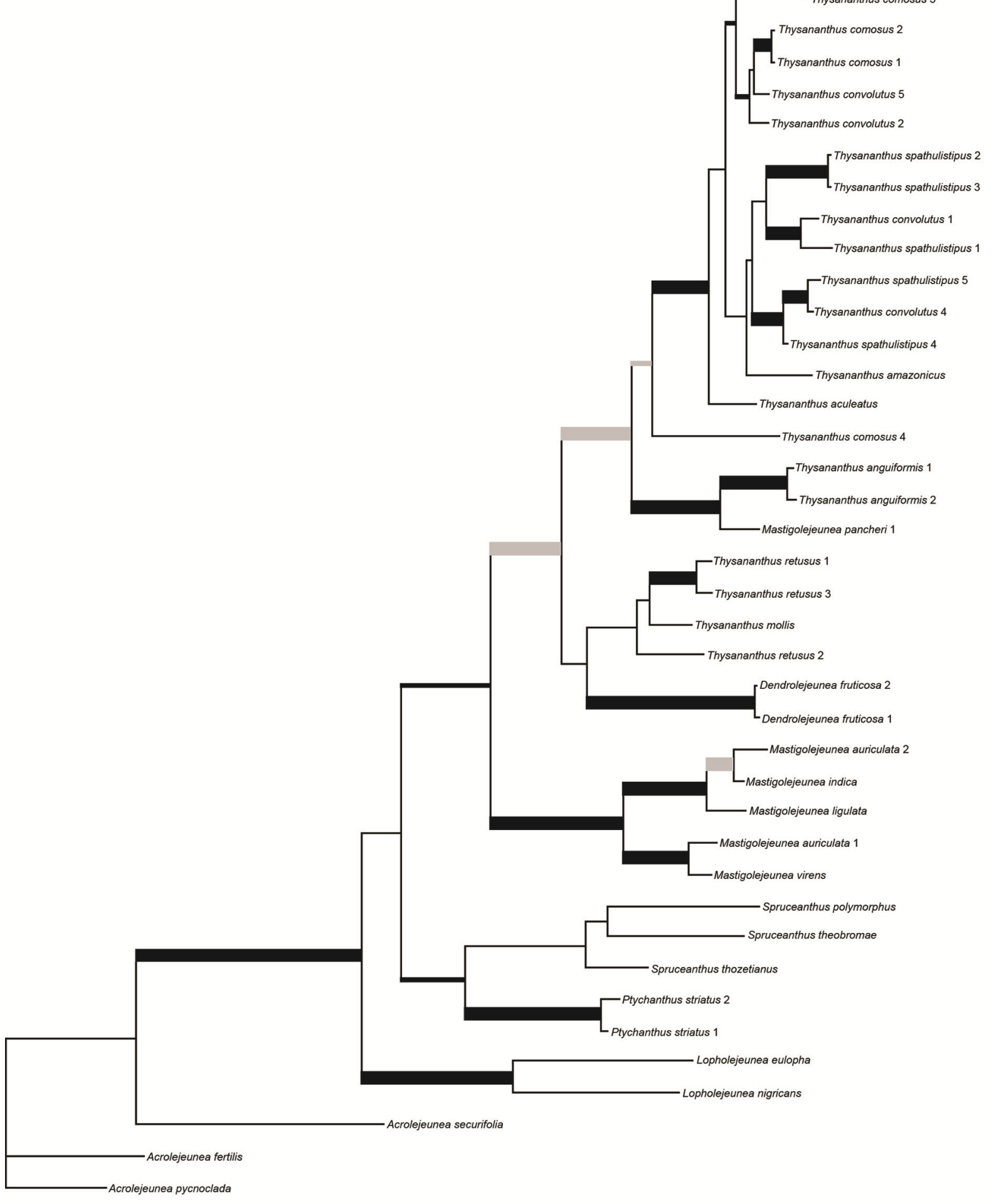

$-0.01$

Fig. 2. Majority rule Bayesian phylogram inferred from the ITS dataset. For further explanation see Fig. 1. 


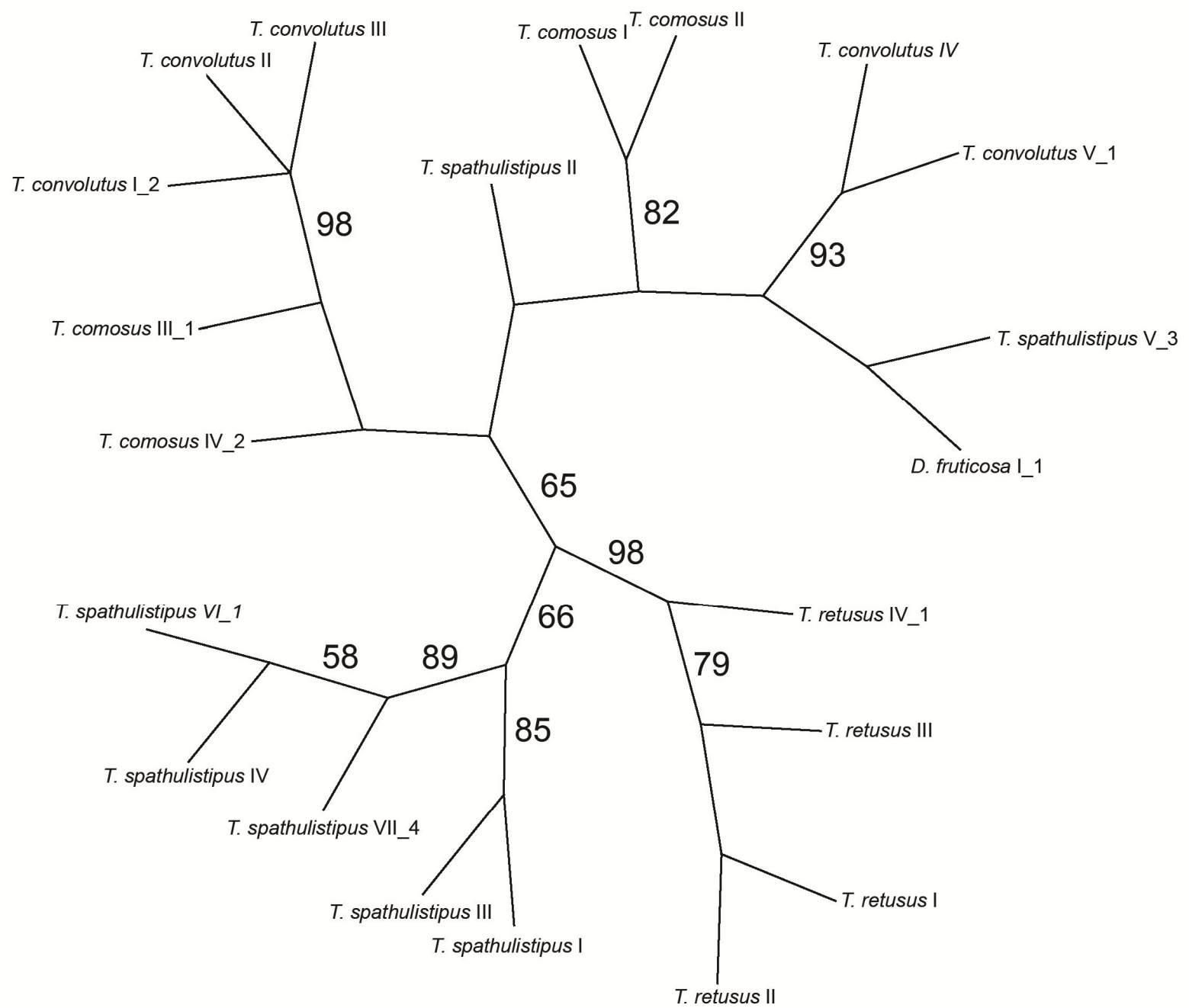

Fig. 3. Strict consensus maximum parsimony tree inferred from phytochemical (terpenoid) characters of Dendrolejeunea fruticosa and four species of Thysananthus, without outgroup. The Roman numerals after the taxon name refers to the phytochemistry voucher (Sukkharak et al., in press) and the arabic ones refers to the molecular voucher (this study). Bootstrap support values $\geq 50 \%$ are given at the branches. 


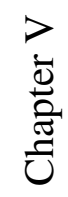

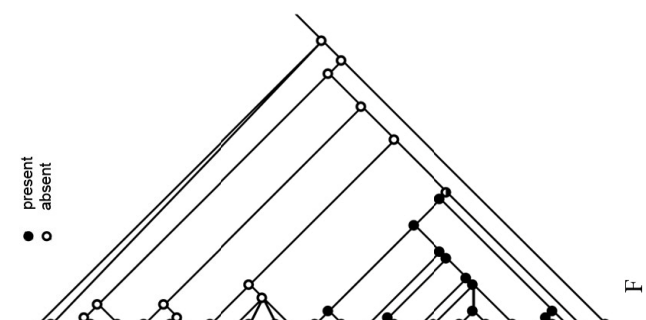

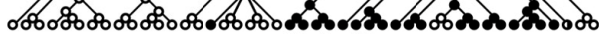
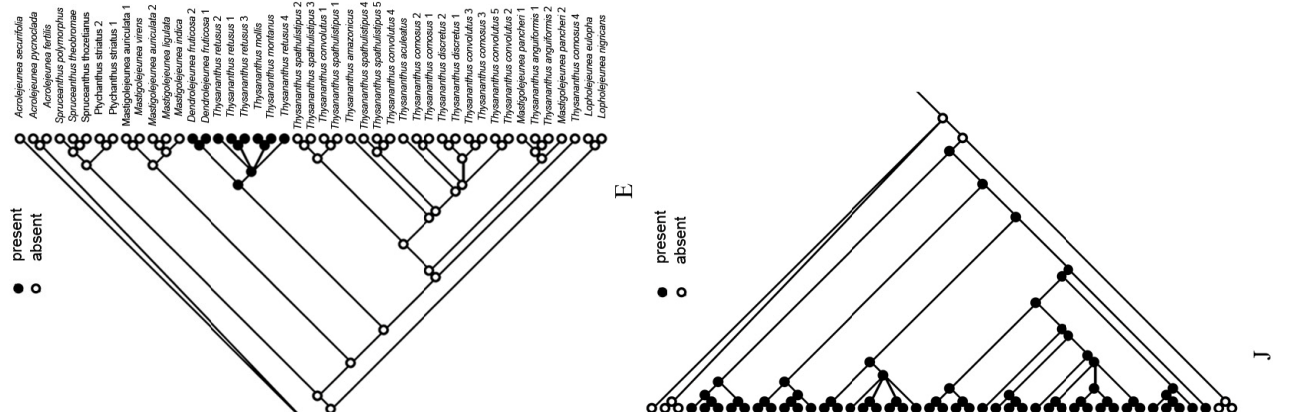

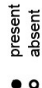

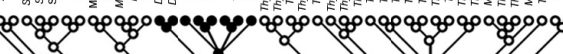
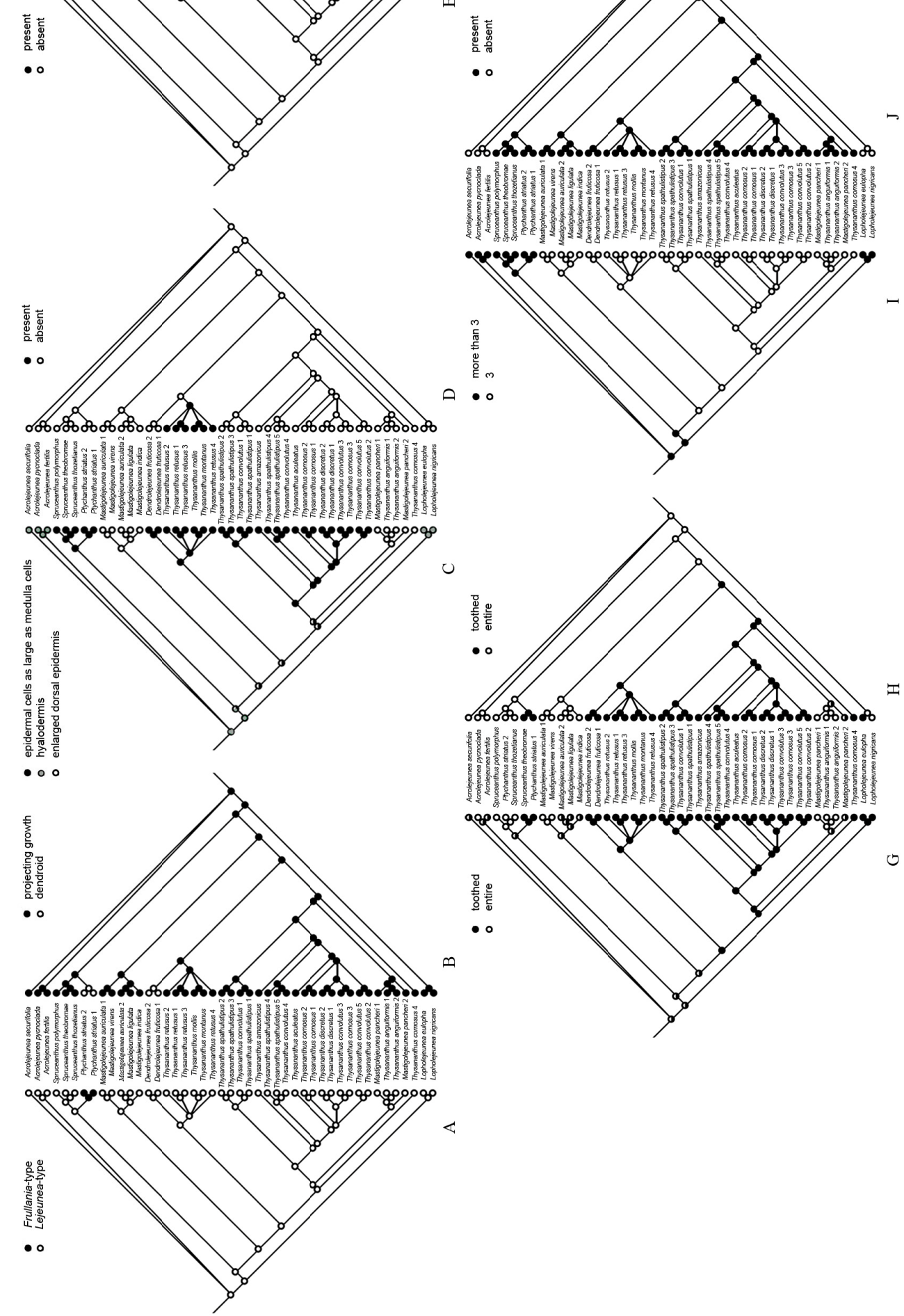


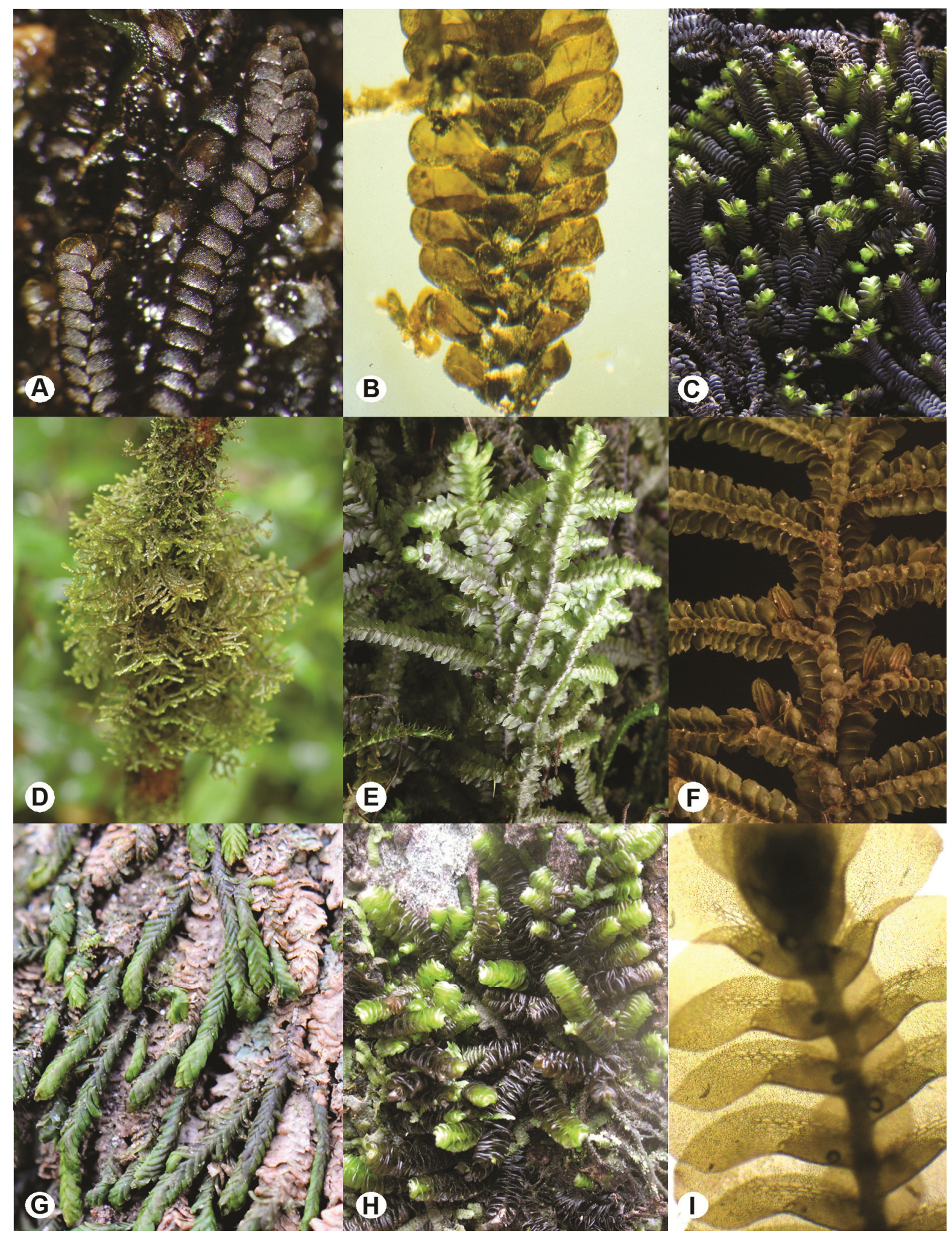

Fig. 5. Representatives of the core Ptychanthoideae. A, Lopholejeunea subfusca (Nees) Schiffn.; B, Mastigolejenea bidentula Gradst., fossil species in Dominican amber, ca. 20 Mya, ventral view; C, Mastigolejeunea repleta (Tayl.) A. Evans; D, Ptychanthus striatus (Lehm. \& Lindenb.) Nees, growth habit; E, Ptychanthus striatus, dorsal view; F, Ptychanthus striatus, ventral view; G, Thysananthus comosus Lindenb.; H, Thysananthus gottschei (Jack \& Steph.) Steph.; I, Thysananthus retusus (Reinw. \& al.) B. Thiers \& Gradst., showing the vitta. Plants sizes: stems with leaves ca. 1.5-3 mm wide. Photographs A: R.-L. Zhu \& R.P. Shi; B: S.R. Gradstein; C: Y.M. Wei \& T. Peng; D: S. Kornochalert; E: T. Hallingbäck; F: J.-P. Frahm; G-H: P. Sukkharak; I: I. Haerida. 
Appendix 1. List of taxa studied. Accession numbers in bold are new for this study. Other sequences are from Wilson \& al. (2007a).

Taxon; DNA no.; geographic origin; herbarium voucher; GenBank accession numbers ( $p s b A$ trnH, $\operatorname{trn} G, \operatorname{trnL}-F, \operatorname{trnS}$-rps4, ITS).

Acrolejeunea fertilis (Reinw. \& al.) Schiffn.; Indonesia; Schäfer-Verwimp 17009 (GOET); PS, PS, DQ987391, PS, DQ987281. A. pycnoclada (Tayl.) Schiffn.; Malaysia; Gradstein 10360 (GOET); PS, PS, PS, PS, PS. A. securifolia (Endlicher) Steph.; Australia, Pócs 99101/B (GOET); PS, PS, PS, PS, PS. Dendrolejeunea fruticosa (Lindenb. \& Gottsche) Lacout.; 1; Thailand; Chantanaorrapint 2112 (PSU); PS, PS, PS, PS, PS. Dendrolejeunea fruticosa; 2; Malaysia; Ilkiu-Borges \& Yong 3026 (GOET); PS, PS, DQ987420, PS, DQ987316. Lopholejeunea eulopha (Tayl.) Schiffn.; Malaysia; Gradstein 10367 (GOET); PS, PS, PS, PS, PS. L. nigricans (Lindenb.) Schiffn.; Malaysia; Gradstein 10357 (GOET); PS, PS, PS, PS, PS. Mastigolejeunea auriculata (Wils.) Schiffn.; 1; Malaysia; Gradstein 10383 (GOET); PS, PS, PS, PS, PS. M. auriculata; 2; USA; Davidson 7686 (GOET); PS, PS, PS, PS, PS. M. indica Steph.; Thailand; Sukkharak 825 (BKF, GOET); PS, PS, PS, PS, PS. M. ligulata (Lehm. \& Lindenb.) Schiffn.; Thailand; Schäfer-Verwimp 16246 (GOET); PS, PS, DQ987465, PS, PS. Mastigolejeunea pancheri Steph.; 1; New Caledonia; Guillaumin \& Baumanner 9343 (GOET); PS, PS, PS, PS, PS. M. pancheri; 2; New Caledonia; Hürlimann 2624 (GOET); PS, PS, PS, PS, PS. M. virens (Ángstr.) Steph.; Thailand; Sukkharak 838 (BKF, GOET); PS, PS, PS, PS, PS. Ptychanthus striatus (Lehm. \& Lindenb.) Nees; 1; Thailand; Sukkharak 755 (BKF, GOET); PS, PS, PS, PS, PS. P. Striatus; 2; India; Schäfer-Verwimp 27974 (GOET); PS, PS, PS, PS, PS. Spruceanthus polymorphus (Sande Lac.) Verd.; Indonesia; Gradstein 10207 (GOET); PS, PS, PS, PS, PS. S. theobromae (Spruce) Gradst. Ecuador; Andersson \& Kautz AK 10 (GOET)PS, PS, DQ987407, PS, DQ987301. S. thozetianus (Gottsche \& F. v. Müll) B. Thiers; Australia; Pócs 01107/M (GOET); PS, PS, DQ987460, PS, DQ987362. Thysananthus aculeatus Herzog; Japan; Inoue s.n. (L); PS, PS, PS, PS, PS. T. amazonicus (Spruce) Schiffn.; French Guiana; Gehrig s.n. (GOET); PS, PS, PS, PS, PS. T. anguiformis (Hook.f. \& Taylor) Steph.; 1; New Zealand; Schäfer-Verwimp \& Verwimp 14058 (GOET); PS, PS, PS, PS, PS. T. anguiformis; 2; New Zealand; Frahm 20-10 (GOET); PS, PS, DQ987455, PS, DQ987355. T. appendiculatus Steph.; Papua New Guinea; Streimann \& Bellamy 18093 (JE); PS, -, -, -, PS. T. comosus Lindenb.; 1; Malaysia; Sukkharak 730 (BKF, GOET); PS, PS, PS, PS, PS. T. comosus; 2; 
Thailand; Inuthai s.n. (PSU); PS, PS, PS, PS, PS. T. comosus; 3; Papua New Guinea; Streimann 41608 (JE); PS, PS, PS, PS, PS. T. comosus; 4; Malaysia; Gradstein \& al. 10366 (GOET); PS, PS, DQ987425, PS, DQ987321. T. convolutus Lindenb.;1 ;Thailand; Sukkharak 803 (BKF, GOET); PS, PS, PS, PS, PS. T. convolutus; 2; Malaysia; Sukkharak 717 (BKF, GOET); PS, PS, PS, PS, PS. T. convolutus; 3; Papua New Guinea; Streimann 41088 (JE); PS, PS, PS, PS, PS. T. convolutus; 4; Indonesia; Gradstein 10205 (GOET); PS, PS, DQ987414, PS, DQ987310. T. convolutus; 5; Malaysia; Gradstein \& al. 10324 (GOET); PS, PS, DQ987431, PS, DQ3987327. T. discretus Sukkharak \& Gradst.; 1; Papua New Guinea; Gradstein 3856 (GOET); PS, PS, PS, PS, PS. T. discretus; 2; Papua New Guinea; Gradstein 3894 (GOET); PS, PS, PS, PS, PS. T. mollis Steph. Papua New Guinea; Gradstein 3792 (GOET); PS, PS, PS, PS, PS. T. montanus Gradst., X.-L. He \& Piippo; Koponen 33958b (H); PS, PS, PS, -, -. T. retusus (Reinw. \& al.) B. Thiers \& Gradst.; 1; Thailand; Sukkharak 743 (BKF, GOET); PS, PS, PS, PS, PS. T. retusus; 2; Australia; Renner 1514 (NSW); PS, PS, PS, PS, PS. T. retusus; 3; Papua New Guinea; Gradstein 3963 (GOET); PS, PS, PS, PS, PS. T. retusus; 4; New Caledonia; Mürlimann 2111 (G); PS, -, PS, -, -. T.spathulistipus (Reinw. \& al.) Lindenb.; 1; Thailand; Sukkharak 788 (BKF, GOET); PS, PS, PS, PS, PS. T. spathulistipus; 2; Thailand; Sukkharak 784 (BKF, GOET); PS, PS, PS, PS, PS. T. spathulistipus; 3; Thailand; Sukkharak 768 (BKF, GOET); PS, PS, PS, PS, PS. T. spathulistipus; 4; Thailand; Sukkharak 793 (BKF, GOET); PS, PS, PS, PS, PS. T. spathulistipus; 5; Indonesia; Schäfer-Verwimp 20790 (GOET); PS, PS, DQ987392, PS, DQ987282. 


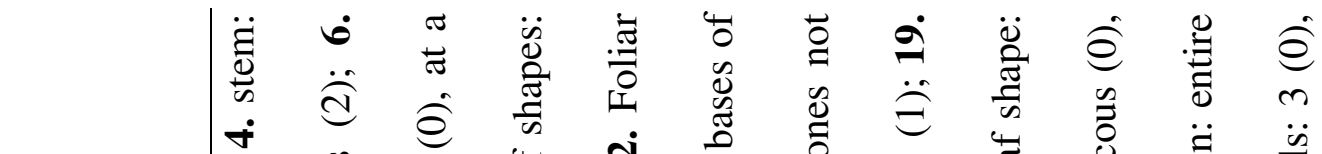

$$
\begin{aligned}
& >\quad \text { 节 } \\
& \text { 产 }
\end{aligned}
$$

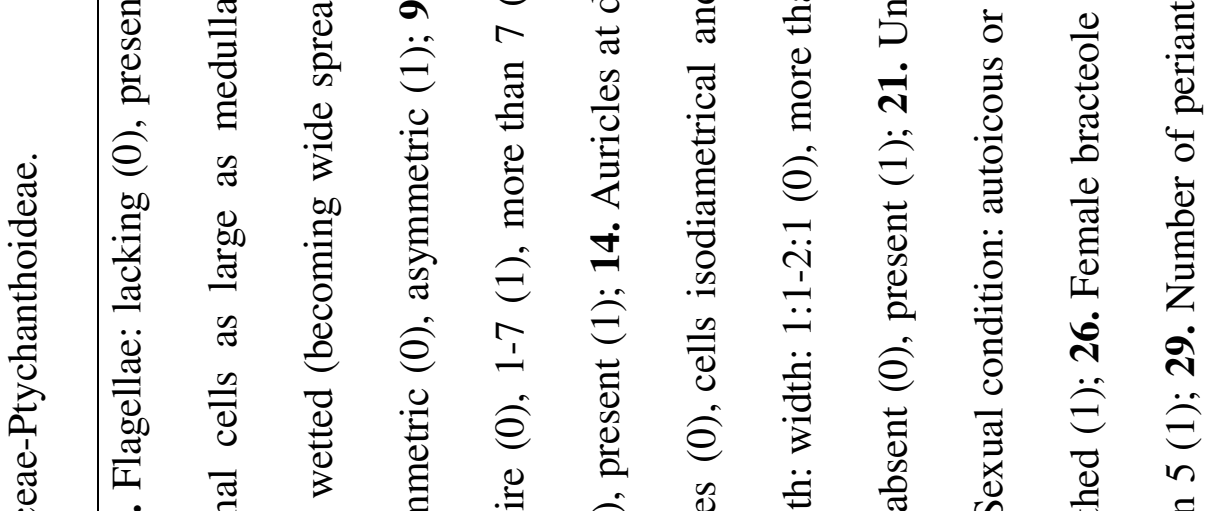

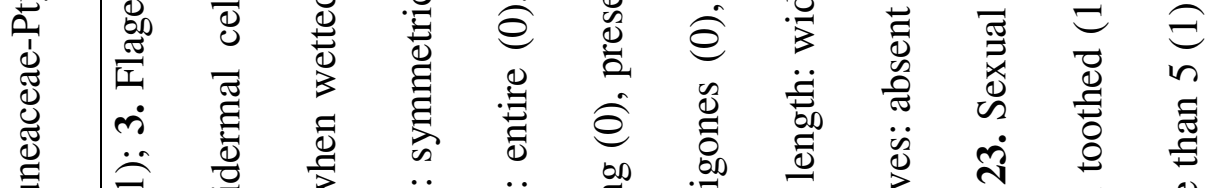

$$
\begin{aligned}
& \text { 言 } \\
& \text { 莺 }
\end{aligned}
$$

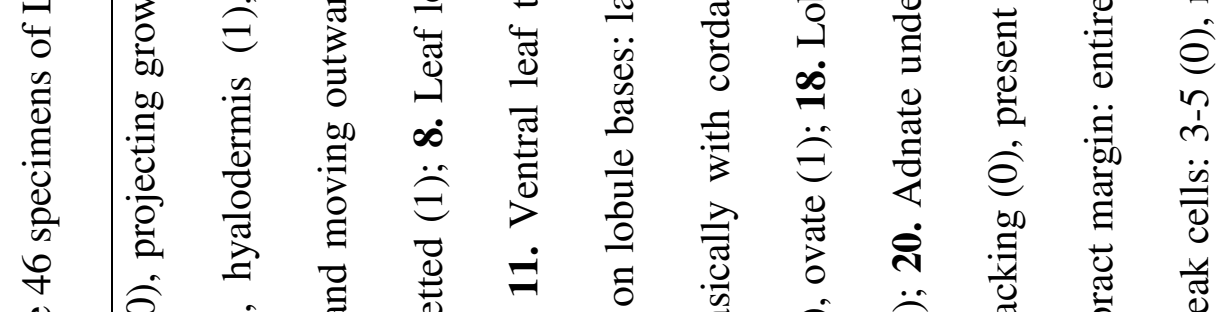

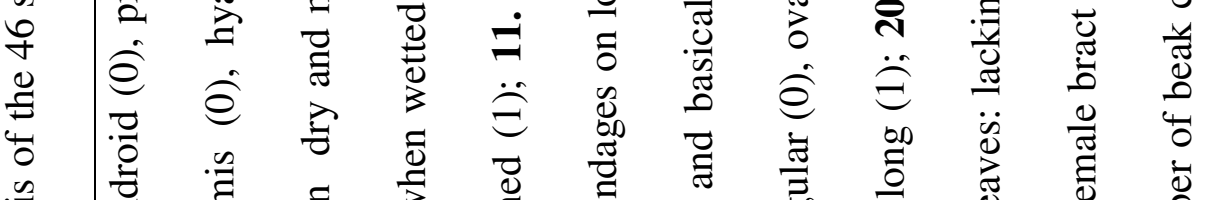

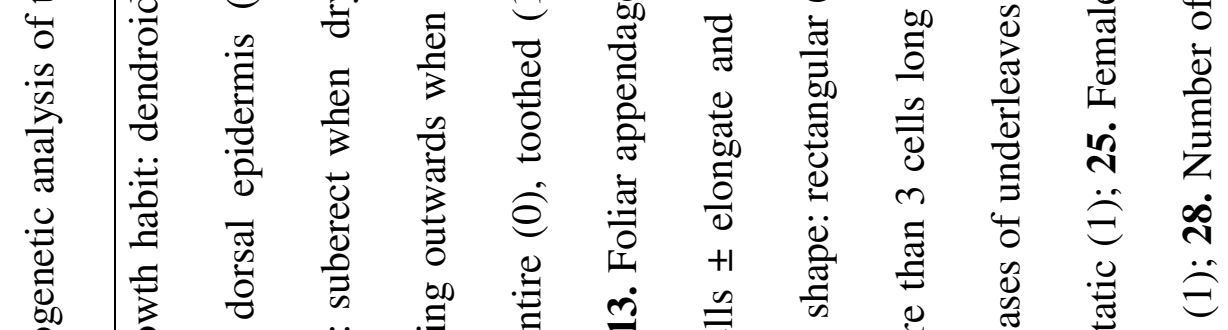

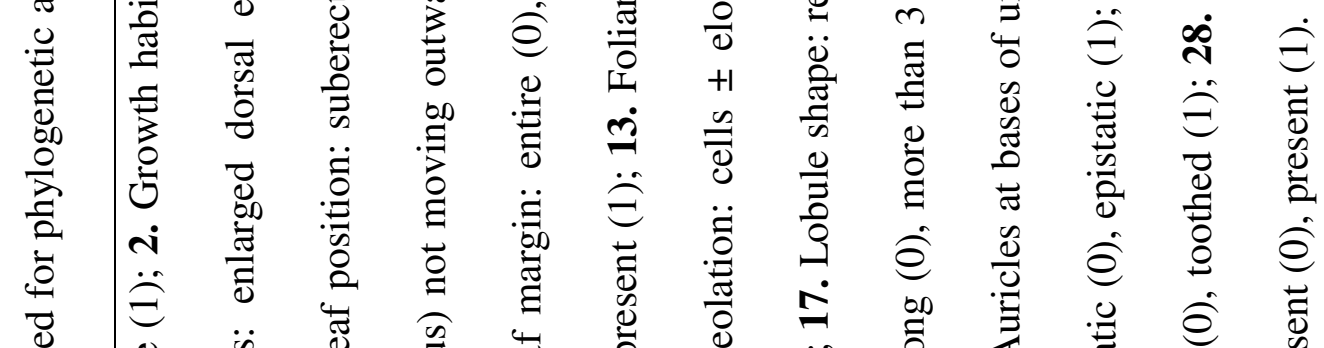

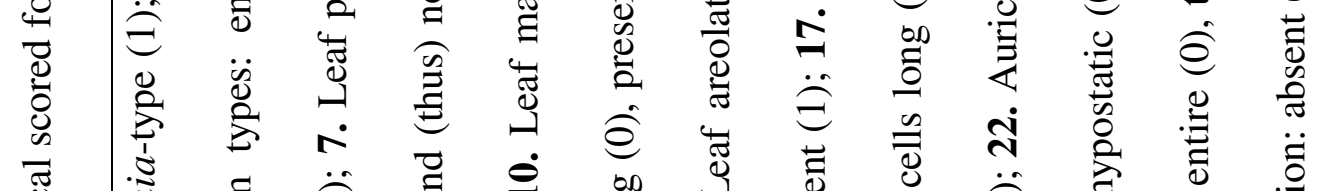

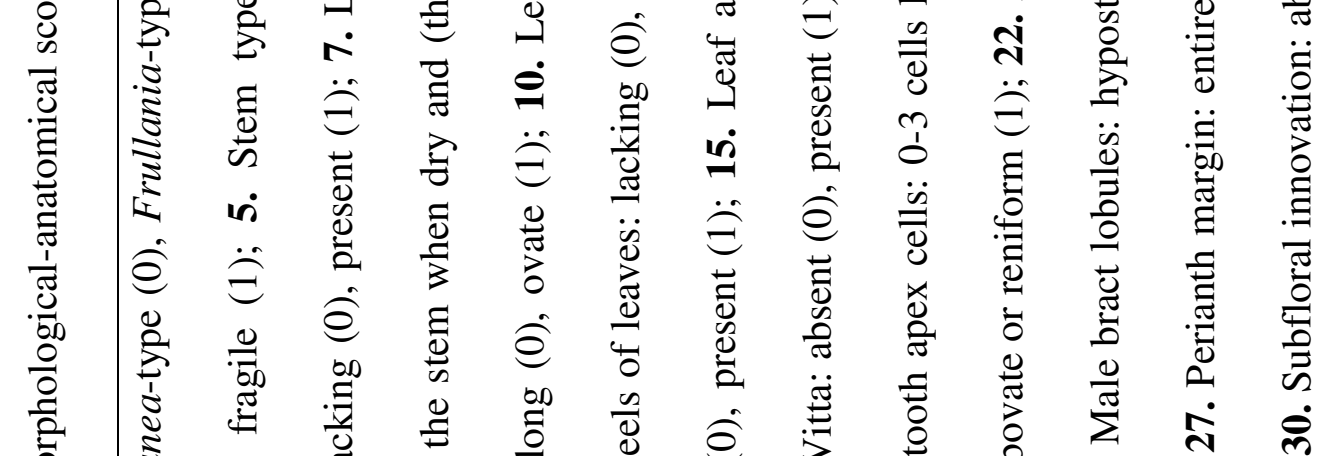

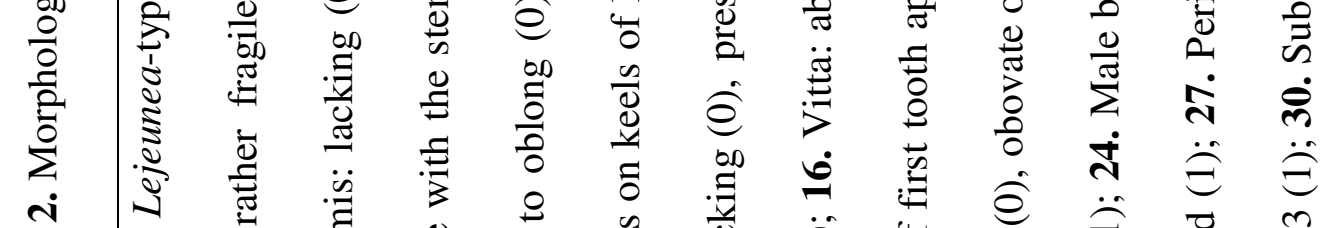

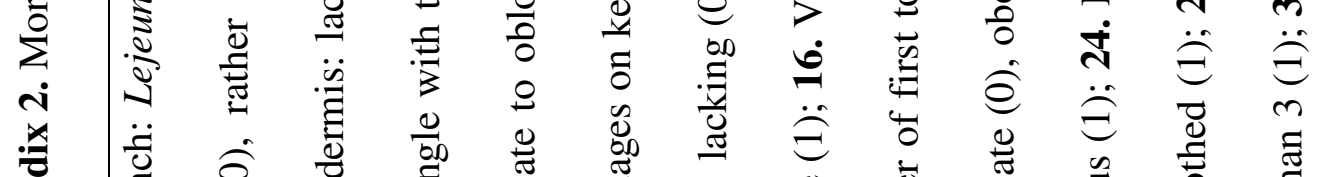

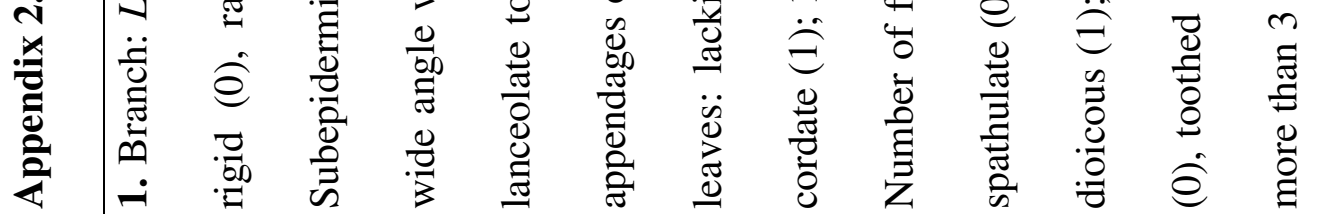




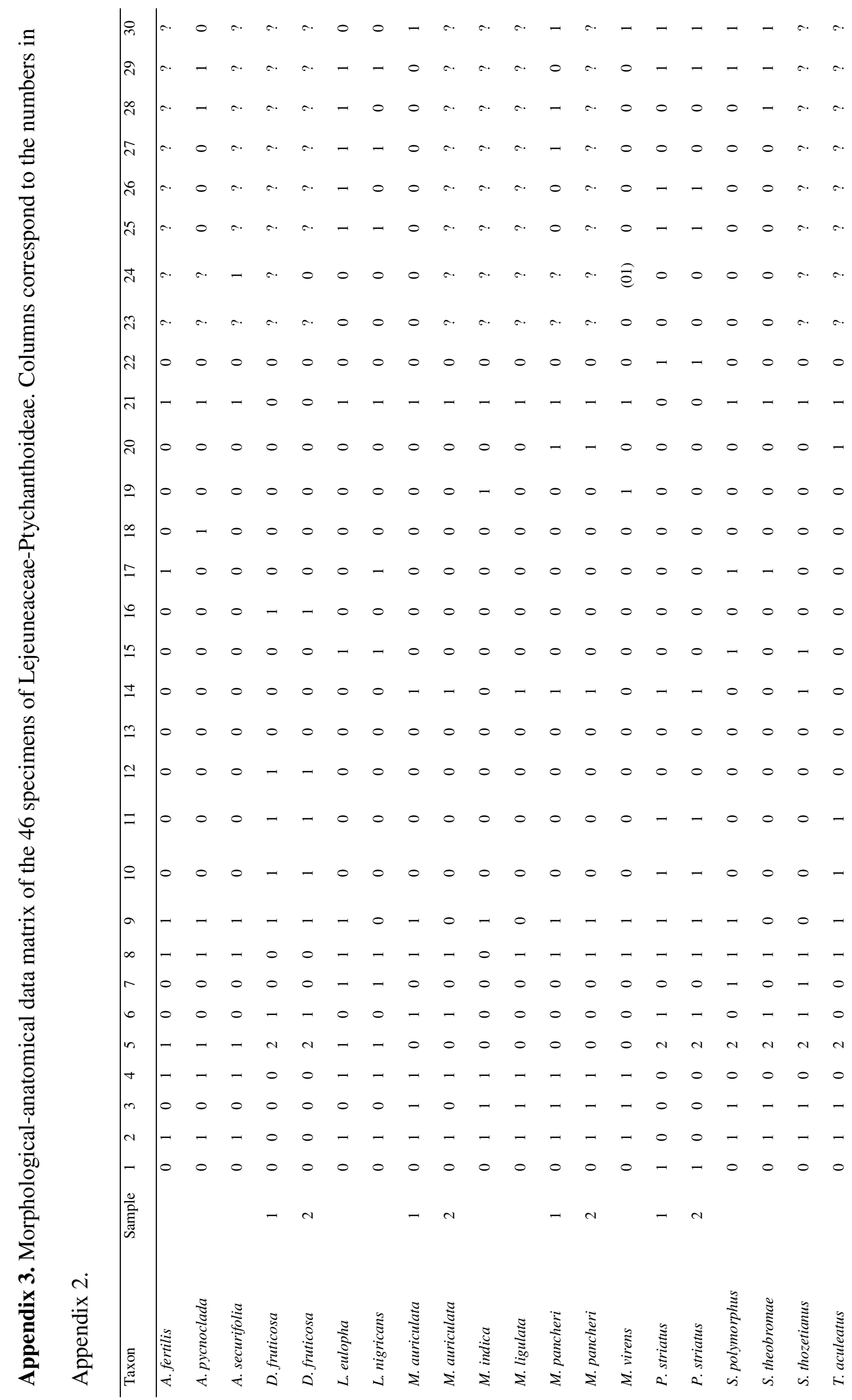




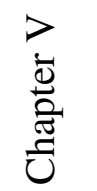

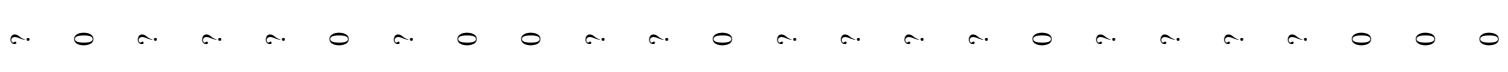

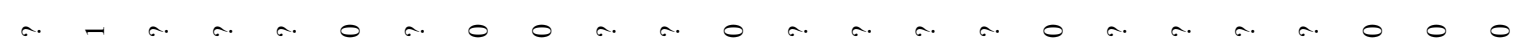

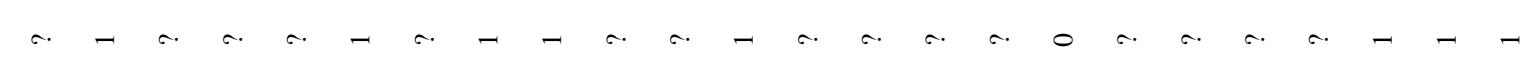

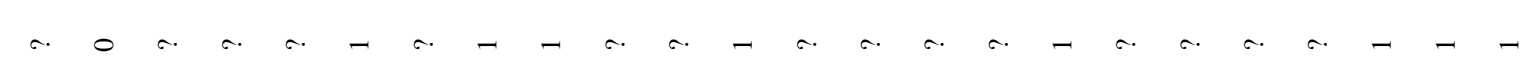

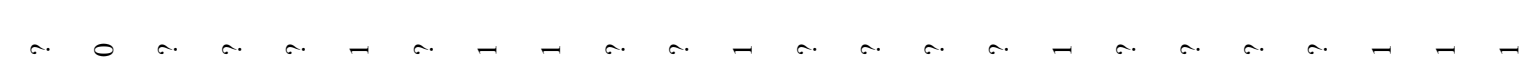

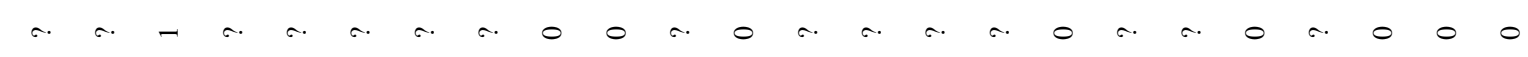

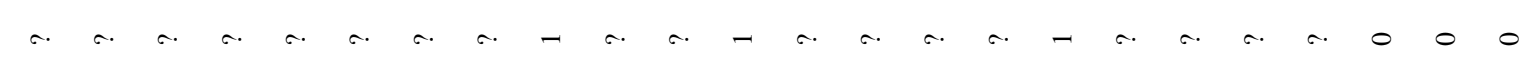

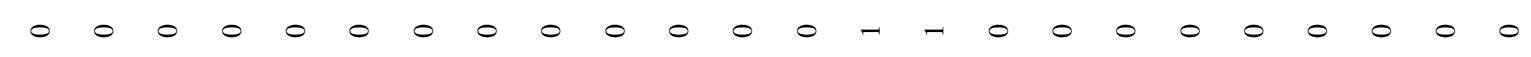

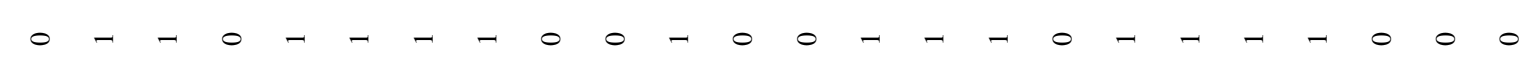

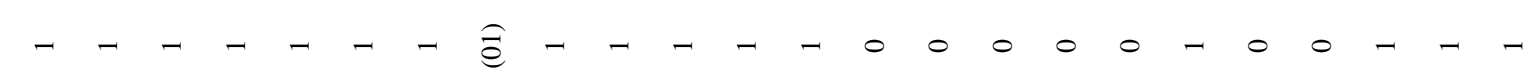

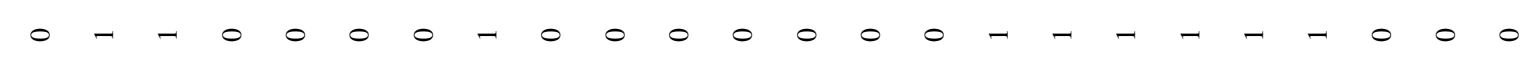
$00000000000000000000-0.0$

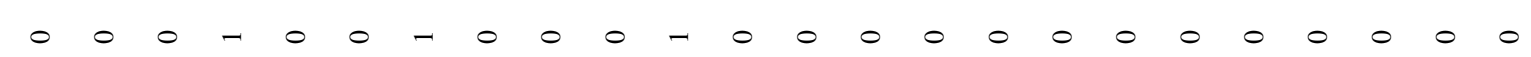

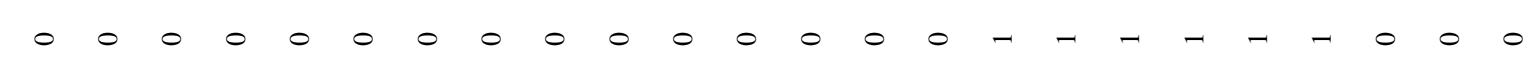

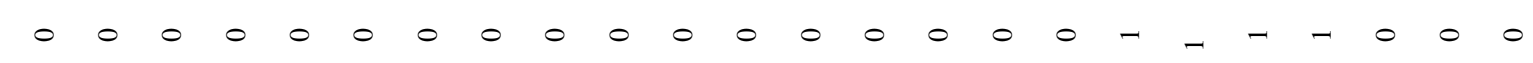

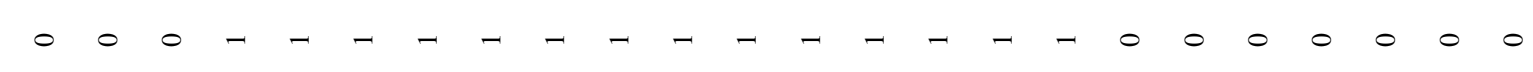

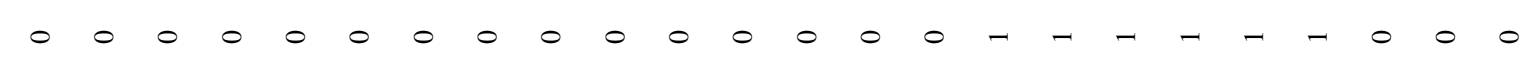

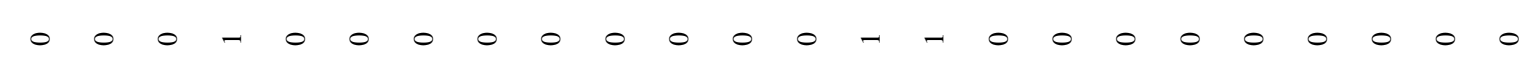

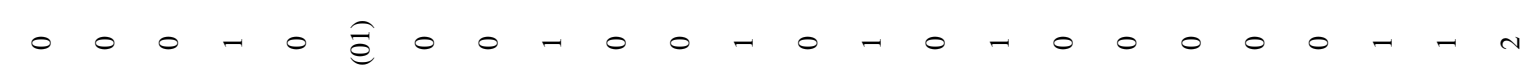

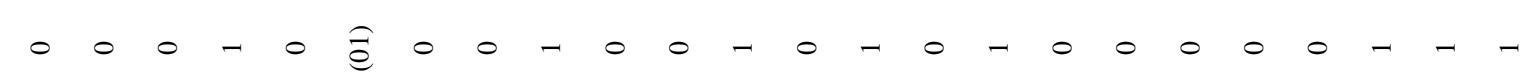

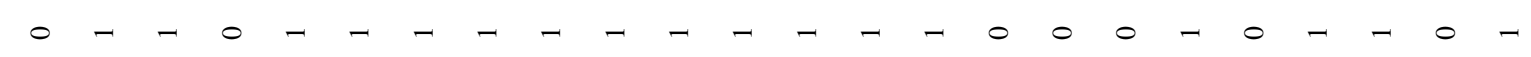

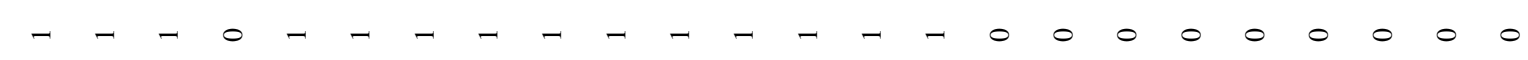

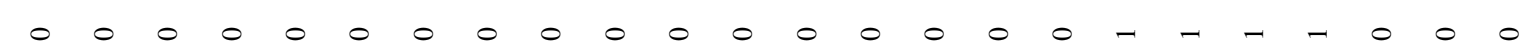

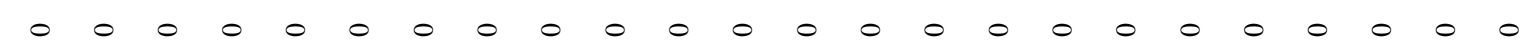

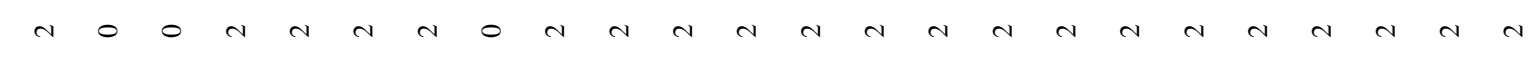

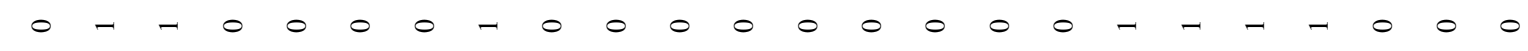

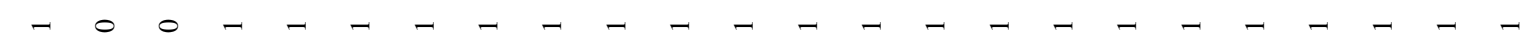

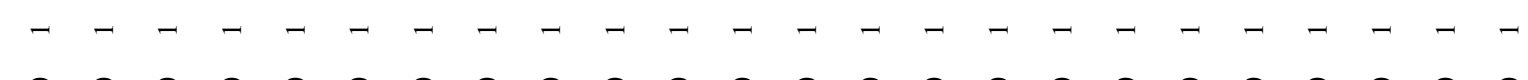

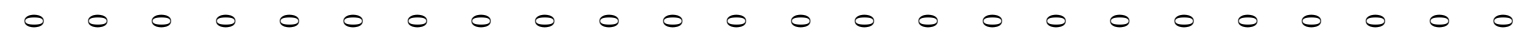
$-4-4 m+4 m+4-4 m+4 \pi$

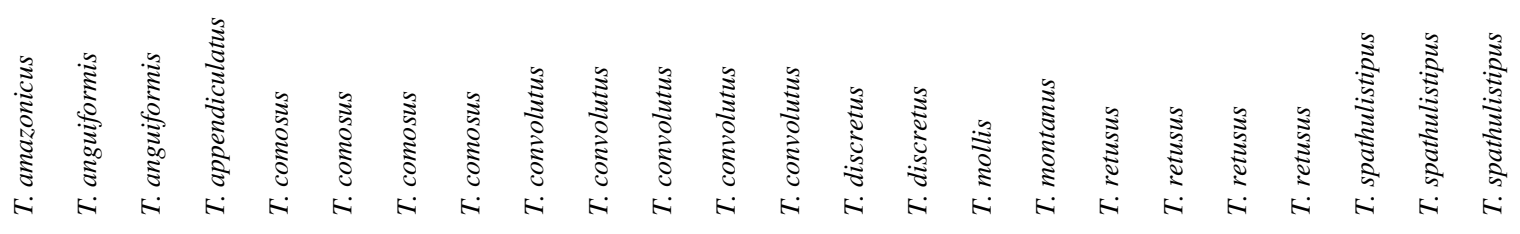




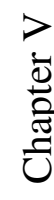

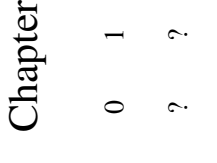

$\circ$

$-\sigma$

$-\quad-$

$-\quad-$

a.

a.

- 0

- 0

$-$

- 0

- 0

- 0

- 0

- 0

- 0

- 0

- 0

巨)

ฮ. -

$-\quad-$

- -

- 0

00

N N

- 0

$--$

$-\quad-$

- 0

$+n$

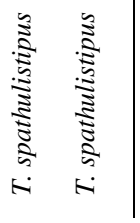




\title{
Monograph of Thysananthus subgenus Thysananthus \\ (Lejeuneaceae, Marchantiophyta)
}

\author{
Phiangphak Sukkharak
}

Department of Systematic Botany, Institute of Plant Sciences, University of Göttingen, Untere Karspüle 2, 37073 Göttingen, Germany

*Department of Biology, Faculty of Science, Burapha University, 169 Long-Hard Bangsaen Road, Saen Sook Sub- district, Mueang District, 20131 Chonburi, Thailand.

E-mail:ppsukk@gmail.com

\begin{abstract}
A world-wide revision of subgenus Thysananthus of the liverwort genus Thysananthus (Marchantiophyta: Lejeuneaceae) leads to the recognition of fifteen species, in two sections: sect. Thysananthus (eleven species) and sect. Dendrolejeunea (Spruce) comb. nov. (four species). The two sections are characterized by the absence resp. presence of a vitta in the leaves. Species are defined by the presence of two or more independent, diagnostic morphological characters. The results of a molecular phylogenetic analysis confirm the placement of Mastigolejeunea pancheri and M. sellingii in Thysananthus and support combining the genus Mastigolejeunea (fourteen spp.) with Thysananthus, as T. subg. Mastigolejeunea (Spruce) comb. nov. Moreover, Dendrolejeunea is returned to Thysananthus based on the molecular results and $T$. gottschei, previously considered a synonym of $T$. convolutus, is resurrected as a separate species. One species, T. combinatus sp. nov., and one variety are newly described, and numerous new combinations are proposed. An artificial key to the species of the genus Thysananthus is provided and each species of subg. Thysananthus is fully described and illustrated, with extensive synonymy and detailed data on habitat and distribution. An annotated list of the species in subg. Mastigolejeunea is also provided; a monograph of the latter subgenus should be the subject of future work. The subg. Thysananthus is pantropical in distribution, with four species ranging into warm temperate regions; the centre of diversity is in Southeast Asia. The species grow as epiphytes in rain forests and montane forests, and include ecological specialists (shade epiphytes, sun epiphytes) as well as generalists. A comparison of sexuality and range size in the genus shows that the endemic species are dioicous and the most widespread ones monoicous, which
\end{abstract}

\footnotetext{
${ }^{*}$ New address after 1 July 2011.
} 
suggests that dispersal has played an important role in shaping the distribution of the species of subg. Thysananthus.

\section{INTRODUCTION}

The genus Thysananthus was first described by Lindenberg in 1844 based on the sharply 3-keeled, dentate-laciniate perianth. Further differential characters have been added by later authors, viz. toothed leaves (Spruce, 1884), elongate leaf cells (Stephani, 1912), purely presence of Lejeunea-type branches, epidermal cells not larger than medullary cells, leaves convolute when dry and cordate trigones, often become coalesced (Gradstein, 1975), and lejeuneoid leaf sequence of innovations (Thiers \& Gradstein, 1989).

Spruce (1884) published Thysano-Lejeunea as one of his 37 subgenera of Lejeunea Lib., a genus which was almost equivalent to the present family Lejeuneaceae. The subgenus Thysano-Lejeunea was more or less equivalent to Thysananthus and was classified in the "Holostipae" Spruce due to its undivided underleaves. Spruce included 7 species in Lejeunea subg. Thysano-Lejeunea: L. amazonica Spruce, L. dissoptera Spruce and L. pterobryoides Spruce from tropical America, and L. comosa (Lindenb.) Spruce, L. convoluta (Lindenb.) Spruce, L. reniloba (Gottsche) Spruce and L. spathulistipa (Lindenb.) Spruce from Southeast Asia.

In the Species Hepaticarum, Stephani (1912) listed 34 species of Thysananthus, which had been restored at generic rank by Schiffner (1893), replacing "Thysano-Lejeunea". Fourteen species of Thysananthus were newly described in his treatment from which only two survived subsequent revisions (including this revision), T. appendiculatus Steph. and T. mollis Steph.

Verdoorn (1934) revised the Asiatic species of Thysananthus and classified them into three sections on the basis of leaf characters: (1) T. sect. Spathulistipae Verd. with six species (T. aculeatus Herzog, T. appendiculatus, T. comosus Lindenb., T. minor Verd., T. richardsianus Verd., T. spathulistipus (Reinw. et al.) Lindenb.) characterized by symmetric and rather plane leaves without vitta; (2) $T$. sect. Convolutae Verd. with two species ( $T$. convolutus Lindenb., T. gottschei (Jack \& Steph.) Steph.) characterized by asymmetric and deeply concave leaves without vitta; and (3) $T$. sect. Vittatae Verd. with three species (T. fruticosus (Lindenb. \& Gottsche) Schiffn., T. mollis, T. planus Sande Lac.) characterized by symmetric, vittate leaves. 
Fulford (1941) recognized four species of Thysananthus in tropical America including T. amazonicus (Spruce) Schiffn., T. comosus, T. evansii Fulford and T. pterobryoides (Spruce) Schiffn., and reduced Lejeunea dissoptera to a synonym of T. comosus. However, in his revision of neotropical Thysananthus, Gradstein (1994) accepted only one species in tropical America, T. amazonicus.

Vanden Berghen (1950) studied Thysananthus in Africa and accepted one species in this continent (T. spathulistipus). Mizutani (1961, 1969, 1977, 1987) and Mizutani and Piippo (1986) published updated descriptions and keys for various Asiatic species, and Hürlimann (1989) treated the species of Thysananthus from New Caledonia, and transferred two New Caledonian species of Mastigolejeunea (Spruce) Schiffn. (M. pancheri Steph., M. sellingii Herzog) to Thysananthus. Thiers and Gradstein (1989) studied the Australian species of Thysananthus and classified the species from that area into two subgenera, subg. Thysananthus (T. fruticosus, T. spathulistipus) and subg. Sandeanthus B. Thiers \& Gradst. (T. australis (Steph.) B. Thiers \& Gradst., T. retusus (Reinw. et al.) B. Thiers \& Gradst.), based on differences in leaf position and areolation.

Gradstein (1992a) proposed a new classification of the species assigned to Thysananthus based on characters of the dried as well as the living plants. He removed the two deviating New World species, T. evansii and T. pterobryoides, from Thysananthus and erected for them the new genus Fulfordianthus Gradst., based on the dendroid habit, the isodiametric leaf cells with evenly thickend walls, lacking any trace of trigones, the lack of oil bodies, etc. The genus Dendrolejeunea (Spruce) Lacout., which is also dendroid like Fulfordianthus, was reinstated for the Asiatic T. fruticosus. The remaining species of Thysananthus were attributed to the two subgenera recognized by Thiers and Gradstein (1989).

Sukkharak \& Gradstein (2010a) described the new species T. discretus Sukkharak \& Gradst. based on hitherto neglected morphological characters of the underleaves, and recognized 10 species in the genus Thysananthus.

As to the systematic placement of the genus Thysananthus, Mizutani (1961) in his taxonomic treatment of the Japanese Lejeuneaceae classified the genus in the subfamily Ptychanthoideae Mizut. and this has been followed and confirmed by all subsequent authors. Morphological phylogenetic analysis of the Ptychanthoideae (Gradstein, 1994; Gradstein et al., 2003) recovered Thysananthus as a member of the Ptychanthinae clade together with Bryopteris (Nees) Lindenb., Mastigolejeunea, Ptychanthus Nees and Schiffneriolejeunea Verd. Dendrolejeunea was not included in the analysis because sporophytes were unknown. Wilson et al. (2007a) in a molecular phylogenetic analysis of the family based on four 
markers recovered Thysananthus (4 species sampled) in a robust clade together with Dendrolejeunea and Mastigolejeunea, being sister to a clade containing Ptychanthus and Spruceanthus Verd. Bryopteris and Schiffneriolejeunea appeared to be more distantly related to Thysananthus. All studies revealed Thysananthus as monophyletic.

Recent molecular data (Sukkharak et al., submitted) based on a complete sampling of all species of Thysananthus confirmed the monophyly of the genus with the inclusion of Dendrolejeunea fruticosa (Lindenb. \& Gottsche) Lacout. Thysananthus gottschei, considered a synonym of $T$. convolutus (Grolle \& Piippo, 1984) and called the edentate form of the latter, was recovered as a separate species. In addition, evidence for an undescribed species, $T$. combinatus sp. nov., was found based on an accession identified as T. comosus. Finally, the placement of the New Caledonian Mastigolejeunea pancheri and M. sellingii in Thysananthus (Hürlimann, 1989) was confirmed and the inclusion in Thysananthus of the genus Mastigolejeunea, long considered very closely related to Thysananthus, appeared necessary.

The purpose of the present treatment is the presentation of a world-wide revision of Thysananthus subg. Thysananthus based on morphological and anatomical study of the types and other available herbarium materials, as well as using phytochemical and molecular evidence (Sukkharak et al., in press; Sukkharak et al., submitted).

\section{MATERIAL AND METHODS}

About 1600 herbarium specimens from BCU, BKF, BM, BM-K, BR, BZ, C, FH, G, GOET, H, HIRO, JE, L, LAE, NICH, NSW, NY, PC, PSU, S, SING, STR, U and W were examined in the present study. Fresh specimens of subg. Thysananthus were studied from Suriname and French Guiana (T. amazonicus), Thailand (T. comosus, T. convolutus var. convolutus, T. fruticosus, T. retusus subsp. retusus, T. spathulistipus), and Malaysia (T. comosus, T. convolutus var. convolutus, T. spathulistipus). The fresh materials have also been used for chemical and molecular studies.

Specimens were examined in the dry state for determining the habit of the leaves. For the description of all other aspects, the specimens were observed, measured, and illustrated with a Leica DMLS microscope after fully moistening with tap water. Measures always represent the complete observed morphological variation of the plants. Shoots, leaves, underleaves, bracts, bracteoles, and perianths were illustrated without cover slips while cells, spores and elaters were studied under cover slips. Bracketed measurements, e.g., in ventral merophyte, stem epidermal and medullary cells, and series of male bracts, indicate that these 
are rare for that taxon when taken as the sum of the component populations, and not that these numbers are uncommon in individual populations.

Shoot width is the width between opposite leaf apices. Leaf length is measured as the distance from the basal insertion of the leaf on the stem to the apex of the leaf lobe. Leaf width is measured parallel to the stem and is the distance from the apical insertion of the free margin of the lobule on the ventral lobe margin to the dorsal margin of the lobe. The ventral margin was carefully compressed before measurement, when the free margin continues into the ventral margin. Lobule length is the distance from the basal insertion of leaf on the stem to the base of first tooth. Lobule width is the widest distance from keel to free margin measured parallel to the stem (Fig. 1A). Underleaf length is the distance from the mid-basal insertion of underleaf to the stem to the middle of apex. The underleaf width is arbitrarily chosen as the widest distance of the underleaves (Fig. 1B). The length of the cells is defined as the longest distance between the trigones, present in the angles. Width is measured perpendicularly to length. Female bracts were measured as leaves while bracteoles were measured as underleaves. Perianth length is the distance from the mid-basal insertion of perianth to the innovation to the basal of the beak. Perianth width is arbitratily chosen as the widest distance of the perianth (Fig. 1C). Characteristics of capsule valves and size of elaters were taken from dehisced capsules while the number of elaters per valve (or capsule) and spore characteristics were taken from mature, undehisced ones. Elaters and spores were observed in fully hydrated condition in water, at $1000 \times$ magnification. The total number of rosettes per spore was difficult to determine, therefore, in this treatment number of rosettes per spore facet is given.

\section{MORPHOLOGY AND ANATOMY}

Growth Habit. Species of subg. Thysananthus usually grow in dense mats over bark or rock. Most species have projecting growth, turning upwards and becoming ascending to erect or projecting downwards and becoming pendent (T. amazonicus). Only $T$. fruticosus has a dendroid or fan-shaped like habit.

Color and size. Plants are pale green to dull green in the field, becoming brownish green to black in older portions. Dried herbarium specimens are pale yellow to dark brown. Most species of subg. Thysananthus are rather robust plants, measuring up to $6.5 \mathrm{~cm}$ long and to $5 \mathrm{~mm}$ wide.

Branching. Branches are always gyrothecal and of the Lejeunea-type (Crandall 1969; Fig. 1D) except for innovations (= branches originating directly below the perianths and 
associated with the inner bracts) which are of the Radula-type (Fig. 1E). Leaf sequence of innovations is lejeuneoid, with the sequence of leaf production begin with a lateral leaf. Consequently, the leaf spiral is dextrorse on innovations originating from the right-hand side of the stem and sinistrorse on innovations on the left-hand side (if viewed from the ventral surface of the plant). Thiers (1985) recognized four patterns of spatial arrangement of the gynoecia in Ptychanthoideae: (1) Simple (innovations lacking or short sterile), (2) monochasial (innovations single and frequently fertile), (3) dichasial (innovations in pairs and repeatedly fertile), and (4) diffuse (innovations variable). A monochasial pattern is particularly characteristic of $T$. amazonicus, T. comosus, T. convolutus, T. gottschei, $T$. pancheri (Steph.) Hürl. whereas a dichasial pattern is found in T. aculeatus, T. anguiformis, T. appendiculatus, T. combinatus, T. discretus and T. montanus Gradst. et al. Both monochasial and dichasial pattern are found in the remaining species.

The presence of flagelliform branches ("flagellae") along the older portions of the stems is common in this subgenus (Fig. 1F). These branches are always curved backwards, towards the stem base, and bear leaves which are much smaller than ordinary branch leaves. Gradstein (1994) suggested that these flagellae may serve as a specialized means of attachment, additional to rhizoids.

Stem structure. The stems are rather rigid except in T. retusus, which are rather small plant with rather fragile stems. The lateral merophytes always meet dorsally on the stem along a straight longitudinal line and the ventral merophyte surface is 6-18 cells wide, being narrowest in $T$. retusus and widest in $T$. discretus. The width of the ventral merophyte in subg. Thysananthus is not a very stable taxonomic character. For the present study, transverse stem sections were made in all species. The stem measures $0.1-0.3(-0.5) \mathrm{mm}$ high $\times 0.1-0.3(-$ $0.45) \mathrm{mm}$ wide. In transverse section the stem is round-orbicular to subelliptic in shape. The total number of epidermal cells varies between 25 and 57 but may be up to 80 in T. discretus and only 18-21 in T. retusus. The number of medullary cells varies between 27 and 225 but may be up to 381 in T. discretus and no more than 27-34 in T. retusus. Epidermal cells as usually large as medullary cells except in T. anguiformis (Hook. f. \& Taylor) Steph., T. combinatus and T. pancheri which have dorsally enlarged epidermal cells. The stem cell walls are always strongly thickened, and are colourless to brown.

Leaves. The leaves in Thysananthus (both subgenera) are inserted incubously and imbricate (rarely contiguous), and divided into a dorsal lobe and a smaller, inflated ventral lobule (Fig. 1A). The leaves are attached to the stems along a J-shaped insertion line which covers the whole length of the straight lateral merophytes (Fig. 1G). When dry the leaves are suberect, strongly convolute and wrapped around the stem. An exception is found in $T$. 
retusus, in which the leaves are spread out widely, loosely reflexed or plane. When moistened, the leaves are weakly to strongly concave, with the apical parts plane or (in $T$. anguiformis, T. combinatus, T. convolutus, T. gottschei, T. pancheri) ventrad (turned to ventral side) and recurved. In $T$. discretus the leaves are clasping the stem when moistened.

The leaf lobes of Thysananthus appendiculatus, T. mollis, T. montanus, T. retusus and T. spathulistipus are symmetrical whereas those of the remaining species are asymmetrical, with the apex positioned towards the ventral side of the leaves. The dorsal bases are cordate or auriculate and the ventral margin is usually upcurved ca. $1 / 2 \times$ leaf length except in $T$. anguiformis, $T$. fruticosus and T. retusus in which it is plane. The leaf margins are usually toothed except in T. amazonicus, T. anguiformis, T. combinatus, T. gottschei, T. montanus, $T$. pancheri and T. retusus. In T. comosus, T. discretus, T. mollis and T. spathulistipus leaf dentation is variable and leaves may be toothed or entire. The variation in leaf dentation observed in the latter species is not uncommon in Lejeuneaceae and also occurs in, e.g., Bryopteris filicina (Sw.) Nees (Gradstein, 1994), Archilejeunea planiuscula (Mitt.) Steph. (Thiers \& Gradstein, 1989; Gradstein et al., 2002), and in some species of Lejeunea (ReinerDrehwald \& Goda, 2000).

The leaf has three hyaline papillae ("slime papillae") as also seen in other species of Lejeuneaceae (Gradstein, 1994). The hyaline papilla is pyriform. Two of them are associated with the outer ends of the insertion line of the leaf, the third one is located at or near the proximal base of the first tooth on the inner surface of the lobule.

The lobule in subg. Thysananthus is oblong-rectangular and $1 / 4-1 / 3 \times$ lobe length (Fig. 1A) except in T. mollis, which has $1 / 8-1 / 10 \times$ lobe length lobule. In T. retusus subsp. sellingii comb. nov. the lobule is $5 \times$ longer than wide whereas in the others it is $2 \times$ longer than wide.

The keel, which connects the lobule with the lobe, is smooth and gradually curved or almost straight. The free margin is plane. The number of teeth on the free margin varies between one and two or lacking. In this treatment, I follow the terminology of Mizutani (1961) and Gradstein (1975) in using "first tooth" and "second tooth" in numerical sense and not in connection with the location of the hyaline papilla. At the apex of the lobule the free margin and the keel mostly meet at an oblique angle, rarely a straight angle. When oblique, the free margin usually continues into the ventral margin of the lobe, rendering it difficult to determine where the free margin ends and the ventral margin of the lobe begins. In $T$. gottschei var. continuus var. nov. the free margin continues over almost the entire length of the ventral margin and sometimes into the dorsal margin of the lobe (Fig. 17B). When straight the free margin ends abruptly at the junction of the keel and the ventral margin of the lobe (Figs. 7B-C; 8A, F; 22B; 23B, E). 
Underleaves. The underleaves in subg. Thysananthus are imbricate and slightly squarrose except in T. aculeatus and T. comosus, where they are channeled/hollow or flat respectively. They are obovate, spathulate or oblong-rectangular in shape and always undivided (Fig. 1B). In some species the underleaf apex is emarginate but bifid underleaves are lacking in this genus. In T. convolutus var. laceratus comb. nov. and T. gottschei var. continuus the apex is recurved or incurved whereas in the other species it is plane. The central region of the underleaf is gibbous. Well-developed auricles at the underleaf bases are always present in T. discretus and sometimes in T. appendiculatus. The base of the underleaf at the place of attachment to the stem, as seen in longitudinal stem section, is always bistratose, lacking an intermediate cell layer, and belongs to Winkler's Stictolejeunea-type (Fig. 1H). The rhizoids are mostly brown, originating from the base of the underleaves. Rhizoid discs are absent.

An unusual feature of subg. Thysananthus is the common presence of adnate underleaves that are connected to leaf bases (Fig. 2A-B) (Sukkharak \& Gradstein, 2010b). The presence of adnate underleaves appears to be a stable and taxonomically relevant feature of T. aculeatus, T. amazonicus, T. anguiformis, T. appendiculatus, T. comosus, T. convolutus, T. gottschei, T. pancheri and T. spathulistipus; in the other species of the subgenus underleaf bases are usually free. Interestingly, it appeared that the adnation of underleaves on branches occurs in a distinct left-right symmetry pattern, on right-hand branches being connected to leaves on the left side and on left-hand branches on the right-hand side.

Appendages of leaves, bracts and perianths. Sukkharak \& Gradstein (2010b) observed further morphological features in subg. Thysananthus, relative to leaf bases. In all species of subg. Thysananthus a small "appendage" may be developed on leaves, female bracts and perianths (Fig. 2A, C-J). In T. anguiformis, T. appendiculatus, T. convolutus var. laceratus, T. discretus, T. fruticosus and T. gottschei var. continuus the appendages are found on the keel of leaves and inserted partially on the stems. In T. fruticosus, the appendages are found on both sides of the stem. In T. appendiculatus, T. convolutus var. laceratus and T. gottschei var. continuus they are always found on one side of the stem only, on the side where underleaves are free and being opposite to the adnate ones, whereas in T. anguiformis they are sometimes found on one side of the stem (Fig. 2A). In species with free underleaves such as T. discretus, however, the position of the appendages is variable and may be on one or both sides of the stems (or lacking). These observations are further evidence for the left-right symmetry on branches in subg. Thysananthus. In all species of subg. Thysananthus wing-like appendages occur on the keels of the female bracts, on one or both sides of the stem (or lacking) and partially inserted on the associated innovation. In addition, a small appendage may be found 
on the mid-basal portion of the bract lobules and on the base of the keels of the perianth (Fig. 2D-F, I). Moreover, an appendage which is attached to the lobule bases and the stem epidermis cells on both sides of the stem was observed in T. mollis, T. montanus and T. retusus (Fig. 2K-L).

Cells. The cells in the leaf lobe are elongate-hexagonal and arranged in diverging rows. An exception is found in T. retusus, in which the cells are (sub)isodiametric (except for the vittate cells). Along the margin of the lobe a row of subquadrate cells is always present. Towards the base of the lobe the cells become slightly larger. The presence of a marked vitta is the special feature of T. fruticosus, T. mollis, T. montanus and T. retusus (Figs. 22K, 27K). Ocelli are lacking in all species of subg. Thysananthus.

The cell walls are smooth and colorless. They consist of a thin middle lamella, with collenchymatic thickenings ("trigones") and intermediate thickenings 1-2(-3) per cell wall. The trigones are heart-shaped ("cordate") possessing two convex sides and one concave side. Often they tend to become large and confluent ("coalesced"), except in Thysananthus retusus, in which trigones and intermediate thickening are indistinct (except for the vittate cells). The cells of underleaves and leaf lobules are smaller than those of the leaf lobes.

Oil bodies are present in all cells of leaves, underleaves, involucrum, and perianth. They were described previously in Thysananthus aculeatus (Mizutani, 1961), T. spathulistipus (Mizutani, 1969), T. retusus (Thiers \& Gradstein, 1989), T. amazonicus and T. discretus (Gradstein, in sh) and are newly described here for T. comosus and T. convolutus. The oil bodies of all species of Thysananthus are coarsely segmented granulose (Calypogeiatype) and narrow ellipsoid to subglobose in shape (Figs. 12P, 13N, 18N, 27N-O). The granules are distinctly protruding beyond the outer membrance, the oil body thus resembling a "grape-cluster" (Schuster, 1966). In margin and median leaf cells their number varies from 2 to 6 , reaching to 8 in vitta cells. The oil bodies may appear to be spherical when laying in transverse position in the cells.

Gametoecia. Thysananthus amazonicus is paroicous, having sexual branches with male bracts below the female bracts, T. aculeatus, T. fruticosus, T. retusus subsp. retusus and T. spathulistipus are autoicous with gynoecia and androecia on separate branches, and the remaining species of subg. Thysananthus are dioicous. The androecium consists of a slightly modified leaf (bract) enveloping two antheridia (Fig. 3B), rarely only one (Gradstein, 1994). The androecia are produced on terminal or intercalary branches except for those of $T$. amazonicus, which are below the gynoecium. The androecial spike in subg. Thysananthus is composed of 2-13 pairs of bracts but may be up to 23 in T. mollis. The bract lobe is similar to the lobe of the vegetative leaf, but smaller in size. The male lobules are strongly inflated and 
teeth are more numerous than in the vegetative leaves. Mostly male bract lobules of subg. Thysananthus are mostly hypostatic (free margin-in ventral view-distinctly overlapping the younger bract) except in T. amazonicus, in which epistatic (free margin curving behind the lobule of the younger bract) and hypostatic bracts can be observed (Fig. 3A). Bracteoles are similar to underleaves or slightly smaller. The mature antheridium is globose and $78-115 \mu \mathrm{m}$ in diameter, and has a unistratose wall of thin-walled and colorless cells. The antheridium is attached to the lateral side of the stem by a straight to curved, uniseriate stalk $11-13 \mu \mathrm{m}$ in diameter and 24-27 cells long (Fig. 3C).

The gynoecium is produced terminal on elongate branches, and consists of a single archegonium surrounded by a perianth and one series of bracts and bracteoles. The bracts are obliquely spreading to subsquarrose and divided into a large dorsal lobe and a plane ventral lobule. The lobes are ovate with margins toothed or entire, and the lobules are broadly ovate and $2 / 3-1 / 2 \times$ lobe length. The bracteoles are spathulate in shape, with emarginate to bifid apex and plane or recurved margins which are toothed or entire. The central region of the bracteoles is gibbous.

The juvenile perianth consists of three portions: (1) a basal portion, surrounding the venter of the archegonium; (2) a central portion, soon becoming triplicate; and (3) a beak, which has completed its development (Fig. 3D). The base of the archegonial neck is surrounded by the beak. The archegonium is flask-shaped and has a long neck of cells extending beyond the beak of the juvenile perianth (Fig. 3E-F). After fertilization, the expanding archegonial venter develops into the calyptra, which surrounds the developing sporophyte (Fig. 3G, J). The rapidly growing, trigonous perianth encloses the calyptra and the developing sporophyte. The mature perianth is emergent and obovate or oblong-cylindrical in shape, and has three sharp keels (two laterals and one ventral). The upper 1/3 of the keels of all species of subg. Thysananthus are toothed except in T. montanus. The teeth are triangular (usually) or long laciniate (in T. appendiculatus, T. combinatus, T. comosus, T. convolutus var. laceratus, $T$. discretus, $T$. fruticosus, $T$. gottschei, $T$. pancheri). The beak is normally 3-5 cells long, reaching to 7 cells long in $T$. discretus.

Sporophytes. The development of the sporophyte takes place entirely within the 1-2layered calyptras as is usual in Lejeuneaceae. The outer cells of the calyptra are larger than the inner cells. At its base, the calyptra is slightly narrowed into a stalk. I found in subg. Thysananthus a conical foot with 5-6 transversal rings of cells. Weis (2001) reported 4-5 transversal cell rings in this subgenus. The foot gradually continues into seta, which is 22-25 cells long, articulate (evenly tiered) (Fig. 3H-I), and in cross section made up of 16 outer cells and 4 inner cells (Fig. 3K). The fully elongate seta is to $2.5 \mathrm{~mm}$ long. 
The mature capsule is dark-brown, globose, and $0.2-0.3 \mathrm{~mm}$ in diameter. Upon dehiscence the capsule splits from apex downward 3/4 of its length into four valves. The valves are $0.6-0.8 \mathrm{~mm}$ long and $0.3-0.5 \mathrm{~mm}$ wide at middle, and widely spread backwards, to $60-90^{\circ}$. The outer valve cells have asymmetrically nodulose trigones and intermediate thickenings which tend to become confluent (Fig. 4B-D). In all species of subg. Thysananthus the shape of hinge (= group of differentiated cells in the lower half of the outer valve surface where the free part of the valve curves outwards upon dehiscence; Weis, 2001), is rectangular (Fig. 4A, D). The inner surface of the valves has 6-7 longitudinal ridges or lamellae (= "elateroids"; Gradstein et al., 2003), which are about 200-230 $\mu \mathrm{m}$ long $\times$ 30-40 $\mu \mathrm{m}$ wide with the tip is strongly tapering (Fig. 4E). The inner cells of the valves are slightly smaller than the outer cells and are covered by fenestrate sheet of thickening, being monofenestrate (one, large pore per cell) or plurifenestrate (several pores per cell), or both (Fig. 4F). The capsule base (inner view) consists of over 96-100 thin-walled quadrate cells, forming a round to slightly quadrate pattern (Fig. 4E).

Mature, but unopened capsules members of subg. Thysananthus have 66 elaters, which are vertical in position and attached to the capsule base and the apical region of the valves. The number and arrangement of elaters are identical in opposite valves, each valve bearing either 15 or 18 elaters (as shown after dehiscence), in a $1+3+5+6$ or $2+4+6+6$ pattern (Fig. 4G). The elaters are linear, 350-550 × 12-20 $\mu \mathrm{m}$, with a single brown spiral which is 5$8 \mu \mathrm{m}$ wide. The tip of the elaters is obtuse but the end is rounded and dilated (Fig. $4 \mathrm{H}$ ).

The mature spores have undergone precocious germination inside the capsules as is usual in the Lejeuneaceae, and consequently they are green and subisodiametric to oblong. The outer surface of the spores is covered by numerous bluntish papillae and 1-4 rosettes per facet. The rosettes are 8-12 $\mu \mathrm{m}$ in diameter and consist of one circle of 5-8 sharp and smooth papillae (Fig. 4I). The sporeling of subg. Thysananthus is of the Lopholejeunea-type (Nehira, 1983).

Asexual reproduction. Special means for asexual reproduction have not been observed in subg. Thysananthus.

\section{KARYOLOGY}

Chromosome numbers and morphology have been reported only for Thysananthus aculeatus and T. spathulistipus (see Fritsch, 1991). These two species have a haploid number 
of $\mathrm{n}=9$, which is characteristic of the Lejeuneaceae and many other liverwort families (Fritsch, 1.c.).

\section{CHEMISTRY}

Ten species of subg. Thysananthus: T. amazonicus, T. appendiculatus, T. comosus, T. convolutus var. convolutus, T. discretus, T. fruticosus, T. gottschei var. gottschei, T. mollis, $T$. retusus subsp. retusus, T. spathulistipus have been investigated for the occurrence of terpenoids, flavonoids, sterols, and aromatic compounds, which are usually stored in the oil bodies (Gradstein et al., 1985; Kruijt et al., 1986; Harinantenaina et al., 2006, Sukkharak et al., in press). The chemical substances not only show strong biological activity but may play an important role in the defence of the plants against environmental hazards (Gradstein, 1994) or predators (Harinantenaina et al., 2006).

Terpenoids. Gradstein et al. (1985) studied the occurrence of terpenoids in Thysananthus amazonicus, T. convolutus var. convolutus, T. discretus (under T. convolutus sample nr. 49), T. mollis and T. retusus subsp. retusus (under T. fruticosus). Later, T. comosus, T. convolutus var. convolutus, T. fruticosus (under Dendrolejeunea fruticosa), T. gottschei var. gottschei (under T. convolutus sample nr. 1-3), T. retusus subsp. retusus and T. spathulistipus were studied by Sukkharak et al. (in press). Cadinane sesquiterpenoids and diterpene acetates are main components in $T$. amazonicus and aromadendrene sesquiterpenoids has been reported from $T$. discretus (Gradstein et al., 1985). Isolepidozene is detected as a major component in $T$. comosus, $T$. convolutus var. convolutus and $T$. spathulistipus, the unidentified $\left(\mathrm{M}^{+}\right) 302,190(100), 81(95)$ as the most abundant component in T. gottschei var. gottschei, pinguisane sesquiterpenoids as major components in T. retusus subsp. retusus, and the unidentified $\left(\mathrm{M}^{+}\right) 304,271(100)$, 105(90) as the most abundant component of T. fruticosus (Sukkharak et al., in press).

It appears that most members of subg. Thysananthus elaborate large amounts of unidentified diterpenoids and diterpene acetates (Gradstein et al., 1985; Sukkharak et al., in

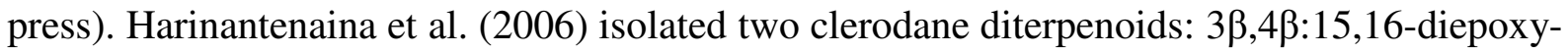
13(16),14-clerodadiene and thysaspathone from T. spathulistipus. Clerodane diterpenoids are very rare among Lejeuneaceae. To evaluate their biological activity, the compounds were examined for inhibition of nitric oxide production in culture media of lipopolysaccharidestimulated RAW 264.7 cells. Thysaspathone exhibited moderate inhibition while 3 $\beta, 4 \beta: 15,16-$ diepoxy-13(16),14-clerodadiene showed weak activity. Finding new agents that inhibit nitric 
oxide production from natural sources is important in drug discovery, since over-production of nitric oxide by inducible nitric oxide synthase is involved in inflammatory disease.

Flavonoids. At least six different flavonoids in Thysananthus appendiculatus are detected by Kruijt et al. (1986).

Sterols. Stigmasterol reported from Thysananthus amazonicus, T. convolutus var. convolutus, T. discretus, T. mollis and T. retusus subsp. retusus is not uncommon in Lejeuneaceae (Gradstein et al., 1985).

Aromatic compounds. Thysananthus appendiculatus producs at least six aromatic hydroxy acids (Kruijt et al., 1986), whereas no trace of aromatic compounds can be detected in T. amazonicus, T. convolutus var. convolutus, T. discretus, T. mollis and T. retusus subsp. retusus (Gradstein et al., 1985).

\section{PHYTOGEOGRAPHY}

The subg. Thysananthus is pantropical in distribution with T. aculeatus (Japan, Taiwan), T. anguiformis (New Zealand), T. fruticosus (Australia, Pacific) and T. retusus subsp. retusus (Japan, Australia, Pacific) ranging into warm temperate regions (Fig. 29). The centre of diversity is in Southeast Asia with eight species occurring in the area (T. aculeatus, T. combinatus, T. comosus, T. convolutus, T. fruticosus, T. gottschei, T. retusus, T. spathulistipus), the latter reaching tropical Africa. Four further species are restricted to Western Melanesia, viz. T. appendiculatus, T. discretus, T. mollis, T. montanus (Papua New Guinea only). Thysananthus anguiformis is endemic to New Zealand and T. pancheri and T. retusus subsp. sellingii to New Caledonia. Thysananthus amazonicus is the only species of the subgenus occurring in the New World.

The distribution of the species and subspecies is summarized as follows (sexuality added as in Gradstein, 1975):

\section{Pluriregional}

a. Africa-Indochina-Malesia-Australia-Pacific

T. spathulistipus (autoicous)

b. Indochina-Malesia-Australia-Pacific

T. fruticosus (autoicous)

c. Japan-Malesia-Australia-Pacific

T. retusus subsp. retusus (autoicous) 
d. India-Indochina-Malesia-Australia

T. convolutus (dioicous)

e. East African Islands (Seychelles)-India (Andaman and Nicobar Islands)-Malesia

T. comosus (dioicous)

f. Japan-Taiwan-Malesia

T. aculeatus (autoicous)

2. Tropical America

T. amazonicus (paroicous and autoicous)

3. Malesia

T. combinatus (dioicous)

T. gottschei (dioicous)

4. Endemic

a. Western Melanesia

T. appendiculatus (dioicous)

T. discretus (dioicous)

T. mollis (dioicous)

b. Papua New Guinea

T. montanus (dioicous)

c. New Caledonia

T. pancheri (dioicous)

T. retusus subsp. sellingii (sexuality? sterile)

d. New Zealand

T. anguiformis (dioicous)

The above data show that all seven endemic species and subspecies of subg. Thysananthus are dioicous where the three most widespread species (T. fruticosus, T. retusus, T. spathulistipus) of the subgenus are monoicous (autoicous). This data may indicate that dispersal plays an important role in the distribution of the species of subg. Thysananthus, as has also been postulated for other liverwort groups (e.g., van Zanten \& Gradstein, 1988; Heinrichs et al., 2009).

\section{ECOLOGY}


The species of subg. Thysananthus usually grow as epiphytes on bark of trees and shrubs, twigs or logs in various stages of decay; T. aculeatus and T. comosus may also occur on rocks. Epiphyllous growth has not been observed in this subgenus. The species have been recorded from sea level to $3100 \mathrm{~m}$ (Table 1), with highest records from Papua New Guinea. The members of subg. Thysananthus occur in rain forests and montane forests, with $T$. aculeatus, T. appendiculatus, T. mollis and T. retusus subsp. retusus being restricted to the understory of the forest and being specialized shade epiphytes, while T. amazonicus and T. convolutus var. convolutus are sun epiphytes occurring in the canopy. The latter species can be found also in plantations. The remaining species are generalists, having rather broad vertical ranges and occuring in the understory as well as in the canopy, in open or more shaded areas, in particular $T$. spathulistipus which is a very common and variable species. Thysananthus comosus and T. spathulistipus are salt-spray tolerant taxa and may occur in coastal forests and mangrove forests.

Table 1. Habitat and elevational range of subg. Thysananthus species.

Species

T. aculeatus

T. amazonicus

T. anguiformis

T. appendiculatus

T. combinatus

50

T. comosus

T. convolutus var. convolutus

$10-2100$
Main habitat

200-2350 along stream, rain forests, montane forests (understory)

0-1000 marsh forest, swamp forest, scrub, savanna, rain forests (canopy)

50-150 rain forests

400-2600 old gardens with regrowth species, grassland with regrowth species, rain forests, montane forests (understory)

park with old planted trees

coastal forest, mangrove forest, rain forests

plantation, old garden site with regrowth species, swamp forest, rain forests, montane forests (canopy)

T. convolutus var. laceratus

T. discretus $760-2700$

rain forests, montane forests

T. fruticosus 
Species

T. gottschei var. gottschei

T. gottschei var. continuus

T. mollis

T. montanus

T. pancheri

T. retusus subsp. retusus

T. retusus subsp. sellingii

T. spathulistipus
Alt $/ \mathrm{m}$

20-2100

1200-3100 montane forests (understory)

1900-2300

40-1100

$125-1700$

400-700

85-2800
Main habitat

rain forests, montane forests

montane forests

rain forests

grassland, rain forests, montane forests (understory)

rain forests

plantation, swamp forest, mangrove

forest, rain forests, montane forests

\section{CONSERVATION}

No subg. Thysananthus species has yet been reported as extinct or endangered. However, four species including T. aculeatus, T. appendiculatus, T. mollis and T. retusus subsp. retusus are shade epiphytes, which are often limited to undisturbed forest and most seriously affected by disturbance (Gradstein, 1992b; Gradstein et al., 2001; Gradstein \& Sporn, 2010). Sun epiphytes, however, may also be limited to undisturbed forest as is shown by the example of $T$. amazonicus (Gradstein, 1994). As advocated by conservation organizations such as IUCN (Hallingbäck \& Hodgetts, 2000), protection of as much as possible of the remaining natural rain forest area may be the best approach to the conservation of the bryophyte flora.

\section{GENERIC RELATIONSHIPS}

Based on the molecular phylogenetic analysis (Sukkharak et al., submitted) Thysananthus is monophyletic and also includes Dendrolejeunea and Mastigolejeunea. Dendrolejeunea, containing only D. fruticosa, first described by Spruce (1884) as a subgenus of Lejeunea. Dendrolejeunea was long included in Thysananthus but was resurrected as a separate genus by Gradstein (1992a). Morphologically, Dendrolejeunea stands out by its dendroid habit, having creeping stoloniform stems and upright, regularly pinnate branches. Mastigolejeunea also first described by Spruce (1884) as a subgenus Mastigolejeunea sect. 
Trigonolejeunea of Lejeunea and had been restored at generic rank by Schiffner (1893). Traditionally, Thysananthus and Mastigolejeunea are separtated based on the different stem types and the possession of entire versus toothed involucres (Bischler, 1964; Thiers \& Gradstein, 1989). Spruce (1884) was inclined to combine these two groups in single subgenus Mastigolejeunea but for remaining the name Thysananthus, he prefered to regard each group subgeneric. However, Schuster (1980) and Gradstein (1985) advocated to combine the two genera into one single genus because of the existence of intermediate taxa. In addition, Sukkharak et al. (submitted) found that $T$. anguiformis and $T$. pancheri are intermediate between Thysananthus and Mastigolejeunea, having adnate underleaves and toothed perianth like in Thysananthus and enlarged dorsal epidermis and entire female involucres of Mastigolejeunea. In addition, T. combinatus has toothed female involucres and perianth like in Thysananthus but its dorsal epidermis is enlarged like the members of Mastigolejeunea. Thiers \& Gradstein (1989) found that M. florea (Mitt.) Paris has undifferentiated dorsal epidermis cells. Finally, entire perianths occur in T. montanus, a species recently described by Gradstein et al. (2002). The latter authors failed to observe the perianth but based on examination of the type specimen I found that this species has entire perianths, being the character of Mastigolejeunea. All these findings indicate that Mastigolejeunea is not sharply separate from Thysananthus and should be included in the latter genus.

Spruceanthus and Ptychanthus are the sister group of Thysananthus (Sukkharak et al., submitted). The differences among the three genera are given below.

Table 2. A comparison of Thysananthus, Spruceanthus and Ptychanthus.

\begin{tabular}{|l|l|l|l|}
\hline \multicolumn{1}{|c|}{ genus } & Thysananthus & Spruceanthus & Ptychanthus \\
\hline growth habit & projecting & projecting & dendroid \\
\hline branching & Lejeunea-type & Lejeunea-type & Frullania-type as cells as \\
\hline stem structure & $\begin{array}{l}\text { epidermal cells as } \\
\text { large as medullary } \\
\text { cells or enlarged } \\
\text { dorsal stem epidermal } \\
\text { cells arge as medullary } \\
\text { cells }\end{array}$ & $\begin{array}{l}\text { large as medullary } \\
\text { cells }\end{array}$ \\
\hline subepidermis & absence & absence & presence \\
\hline leaf cells & $\begin{array}{l}\text { elongate (isodiametric } \\
\text { in } T \text {. retusus) }\end{array}$ & isodiametric & elongate \\
\hline oil bodies & segmented & homogeneous & segmented \\
\hline
\end{tabular}




\section{CLASSIFICATION}

Based on the molecular phylogenetic analysis (Sukkharak et al., submitted), the genus Thysananthus is divided in this monograph into 2 subgenera: subg. Thysananthus (15 spp., 4 varieties, 2 subspecies) and subg. Mastigolejeunea (Spruce) comb. nov. (14 spp.). The subgenera are characterized by the toothed resp. entire perianth and possibly by the different numbers of elaters in the capsule (66 resp. 72). Subgenus Thysananthus is divided into two sections: sect. Thysananthus and sect. Dendrolejeunea (Spruce) comb. nov. Each section is divided into two series: ser. Thysananthus and ser. Anguiformes ser. nov. in sect. Thysananthus, and ser. Dendrolejeunea and ser. Sandeanthus (B. Thiers \& Gradst.) comb. nov. in sect. Dendrolejeunea. A synopsis of the classification is shown below.

The species concept applied in this monograph is similar to the one used by Gradstein $(1975,1994)$. The concept is based on the assumption that the more differences can be found among groups of populations, the more likely it is that a biological species is at hand. Accordingly, species are defined here by the presence of two or more independent, diagnostic characters. When clear-cut intraspecific discontinuities were found, two categories were applied: subspecies and varieties. The difference between both categories is geographical. Varieties are sympatric forms, whereas subspecies are allopatric forms with geographic distributions of their own which are distinct from the area occupied by the other subspecies of the same species (Gradstein, 1975).

In its current circumscription, subg. Thysananthus is mainly characterized by (1) Lejeunea-type vegetative branches, (2) stem epidermal cells large as medullary cells (dorsal epidermal cells enlarged in T. combinatus, T. anguiformis, T. pancheri), (3) leaves convolute when dry (spread out widely in T. retusus), (4) Leaf cells elongate and trigones cordate (isodiametric and trigones faint in T. retusus), (5) adnate underleaves present (absent in $T$. discretus, T. fruticosus, T. mollis, T. montanus), (6) gynoecial innovations present and with lejeuneoid leaf sequence, (7) toothed female involucres (entire in T. anguiformis, $T$. pancheri), and (8) perianth sharply 3-keeled and toothed (entire in T. montanus).

The distinction of species and infraspecific taxa in subg. Thysananthus is mainly based on character states of growth habit, leaf, lobule, auricle, foliar appendage, leaf cell, underleaf, adnation of leaf and underleaf, and androecium. 
a. Growth habit. Growth habit separates the series Dendrolejeunea (Thysananthus fruticosus) from the rest of subg. Thysananthus.

b. Leaf. Particularly important is the appearance of the leaf when dry, which separates Thysananthus retusus from the rest of subg. Thysananthus, whereas T. convolutus separates from $T$. discretus by the appearance of the leaf when wet. In addition, T. mollis and $T$. montanus are distinguished by the shape of the leaf lobe.

c. Lobule. The length of the lobule can be used for distinguishing the subspecies of Thysananthus retusus.

d. Auricle. The presence of an auricle at the base of the underleaf separates Thysananthus discretus from T. convolutus.

e. Foliar appendage. An appendage on the leaf keel is found only in Thysananthus appendiculatus, T. convolutus var. laceratus, T. discretus and T. gottschei var. continuus but may be present on the keels of bracts and perianths, and on the mid-basal portion of bract lobules in all Thysananthus species. Moreover, the appendage which is attached to the lobule bases and the stem epidermis cells separates the series Sandeanthus (T. mollis, T. montanus, T. retusus) from the rest of subg. Thysananthus.

f. Leaf cell. The presence or absence of a vitta is the principal morphological character for distinguishing the sections of subg. Thysananthus. In addition, T. retusus is separated from the rest of subg. Thysananthus by its (iso)diametric leaf cells.

g. Underleaf. Thysananthus aculeatus and T. comosus are separated by the shape and appearance of underleaves. In addition, the varieties of $T$. convolutus and T. gottschei are distinguished by the recurved underleaves.

h. Adnation of leaf and underleaf. The presence of adnate leaves and underleaves is a stable and characteristic feature of Thysananthus aculeatus, T. amazonicus, T. anguiformis, T. appendiculatus, T. comosus, T. convolutus, T. gottschei, T. pancheri and T. spathulistipus. In $T$. combinatus and T. retusus, the underleaves and leaves may be adnate or free.

i. Androecium. Mostly male bract lobules of subg. Thysananthus are hypostatic, except in T. amazonicus, in which epistatic and hypostatic can be found. Moreover, $T$. amazonicus is the only paroicous species, all other species are autoicous or dioicous.

The classification of Thysananthus in this monograph is as follows:

Thysananthus subg. Thysananthus

sect. Thysananthus

ser. Thysananthus

\section{T. aculeatus Herzog}


2. T. amazonicus (Spruce) Schiffn.

3. T. appendiculatus Steph.

4. T. combinatus sp. nov.

5. T. comosus Lindenb.

6. T. convolutus Lindenb.

var. convolutus

var. laceratus (Steph.) comb. nov.

7. T. discretus Sukkharak \& Gradst.

8. T. gottschei (Jack \& Steph.) Steph.

var. gottschei

var. continuus var. nov.

9. T. spathulistipus (Reinw. et al.) Lindenb.

ser. Anguiformes ser. nov.

10. T. anguiformis (Hook. f. \& Taylor) Steph.

11. T. pancheri (Steph.) Hürl.

sect. Dendrolejeunea (Spruce) comb. nov.

ser. Dendrolejeunea

12. T. fruticosus (Lindenb. \& Gottsche) Schiffn.

ser. Sandeanthus (B. Thiers \& Gradst.) comb. nov.

13. T. mollis Steph.

14. T. montanus Gradst. et al.

15. T. retusus (Reinw. et al.) B. Thiers \& Gradst.

subsp. retusus

subsp. sellingii (Hürl.) comb. nov.

Thysananthus subg. Mastigolejeunea (Spruce) comb. nov.

16. T. auriculatus (Wils.) comb. nov.

17. T. calcaratus (Steph.) comb. nov.

18. T. floreus (Mitt.) comb. nov.

19. T. humilis (Gottsche) comb. nov.

20. T. integrifolius Steph.

21. T. innovans (Spruce) comb. nov.

22. T. ligulatus (Lehm. \& Lindenb.) comb. nov.

23. T. plicatiflorus (Spruce) comb. nov.

24. T. reconditus (Steph.) comb. nov.

25. T. recurvifolius (Mizut.) comb. nov. 
26. T. repletus (Taylor) comb. nov.

27. T. truncatus (Mizut.) comb. nov.

28. T. undulatus (Gradst. \& Grolle) comb. nov.

29. T. virens Ångstr.

In this monograph an artificial key to the species of the genus Thysananthus is provided and each species of subg. Thysananthus is fully described and illustrated, with extensive synonymy and detailed data on habitat and distribution. In addition, an annotated list of the species in subg. Mastigolejeunea is provided. A monograph of the latter subgenus should be the subject of future work.

\section{TAXONOMIC TREATMENT}

Thysananthus Lindenb., in Lehmann, Nov. Stirp. Pug 8: 24. 1844; Mizutani (1961: 152); Arnell (1963: 235); Thiers \& Gradstein (1989: 66); Gradstein (1992a: 44); Gradstein (1994: 83); Gradstein et al. (2002: 70); Wigginton (2004: 282). Lejeunea subg. Thysanolejeunea Spruce, Trans. Proc. Bot. Soc. Edinburgh 15: 105. 1884. Lejeunea subg. Mastigolejeunea sect. Thysanolejeunea Spruce, Trans. Proc. Bot. Soc. Edinburgh 15: 100. 1884. Thysanolejeunea (Spruce) Steph., Hedwigia 28: 263. 1889, nom. inval. fide Zijlstra (1982, 1983).--Type: Thysananthus comosus Lindenb. Genus named for its brush-like shoots.

Plants dioicous, autoicous, or paroicous, growing in dense mats, habit deliquescent with dendroid growth, having creeping stoloniform stems and upright, regularly pinnate branches (T. fruticosus) or with projecting growth and irregularly (1)-pinnate, becoming ascending to erect or projecting downwards and becoming pendent (T. amazonicus), pale green to dull green, becoming brownish green, dark brown to black in older portions, when dry pale yellow, yellowish brown, reddish or dark brown, to $6.5 \mathrm{~cm}$ long $\times 1-5 \mathrm{~mm}$ wide, branches Lejeunea-type, flagellae present on the older portions of stems. Stems rather rigid (strongly rigid in $T$. discretus, rather fragile in $T$. reconditus and $T$. retusus); lateral merophyte straight longitudinal line, ventral merophyte 6-18 cells wide; in cross section round-orbicular to subelliptic in shape, $0.1-0.3(-0.5) \mathrm{mm}$ high $\times 0.1-0.3(-0.45) \mathrm{mm}$ wide, composed of (18)25-57(-80) epidermal cells surrounding (27-)49-225(-381) medullary cells in 8-18(-22) layers, epidermal cells usually not larger than medullary cells, occasionally dorsal epidermal cells larger and somewhat thinner-walled than medulla and ventral epidermal cells (in $T$. 
anguiformis, T. combinatus and $T$. pancheri), all cells with thickened walls, walls of epidermal cells brownish, those of medullary cells hyaline, pale brownish or yellowish brown. Leaves incubous, with a dorsal lobe and a smaller ventral lobule, imbricate, rarely contiguous ( $T$. retusus), attached to the axis along a J-shaped insertion line which covers the whole length of the straight lateral merophytes, merophytes not interlocking; leaves when dry suberect and convolute (wide spreading and flat in $T$. retusus), when moist weakly concave with apical part plane and not recurved, to strongly concave with apical part turned to ventral side and recurved (in T. anguiformis, T. combinatus, T. convolutus, T. gottschei and T. pancheri); dorsal lobes symmetrically ovate to ligulate, lanceolate, oblong to falcate or asymmetrically ovate to oblong-falcate, apex round to acute, mucronate or apiculate, dorsal base cordate or auriculate, dorsal margin entire or with triangular teeth (serrate in T. comosus), ventral margin usually upcurved $1 / 2 \times$ leaf length to over most of its length (plane in T. anguiformis, $T$. fruticosus and T. retusus), becoming flat near the apex, entire or with triangular teeth; cells arranged in diverging rows, elongate-hexagonal with acute ends (subisodiametric to isodiametric in $T$. retusus), vitta cells absent or present in midportion of lobe, extending to base, $2 / 3 \times$ lobe length, median cells $12-35(-45) \times 5-15 \mu \mathrm{m}$, at leaf base slightly larger, towards the margins becoming gradually smaller, at margins subquadrate, cell walls thin, trigones cordate, often coalesced, intermediate thickenings 1-2(-3) per cell wall (cell walls evenly thickened, trigones and intermediate thickening faint in T. retusus); cuticle smooth; oil bodies Calypogeia-type, 2-6(-8) per cell. Lobules oblong-rectangular, usually 1/5-1/3× lobe length (1/10-1/8× in T. mollis), inflated, occasionally with a tiny appendage on the surface at the base; keel gradually curved, the surface smooth, sometimes with an orbicular to oblong appendage; lobule apex usually oblique and longly continuing into the ventral lobe margin, occasionally transverse and not or shortly continuing into the ventral lobe margin (in $T$. aculeatus, T. anguiformis, T. fruticosus and T. retusus), free margin plane, apex with 1 narrow-elongate tooth, with 1(-2) triangular teeth, or without teeth; hyaline papilla pyriformoblong, 27-37 $\times 7-12 \mu \mathrm{m}$, at or near the proximal base of the tooth on the inner surface of the lobule. Underleaves imbricate, slightly squarrose (channeled or hollow in T. aculeatus, flat in T. comosus), broadly obovate, ovate or spathulate, apex rounded or truncate to emarginate, entire to serrate or toothed, plane, recurved or incurved, margins entire, recurved, central region gibbous, bases cuneate or auriculate, underleaf bases free or adnate with leaves on one side, on left-hand side for right branches and right-hand side for left branches (underleaf bases free or adnate with leaves on one side in T. combinatus and T. retusus), insertion line slightly arched; cells becoming longer towards the base of the underleaf; underleaf attachment bistratose; rhizoids brown; rhizoid discs absent. Androecia terminal-intercalary on Lejeunea- 
type branches (below the gynoecium in T. amazonicus), bracts and bracteoles in $2-13(-23)$ pairs, bracts hypostatic (epistatic in T. ligulatus, occasionally epistatic in T. amazonicus), ovate, apex acute to apiculate or mucronate, margins entire or with 1-2 teeth, lobules strongly inflated; bracteoles similar to underleaves; antheridia (1-)2 per bract. Gynoecia terminal on elongate branches, with 1-2 lejeuneoid innovations, innovations repeatedly fertile, forming a monochasial or dichasial pattern or both; bracts in one pair, obliquely spreading to subsquarrose, lobe ovate, ligulate or lanceolate, apex acute-apiculate, entire or with triangular or laciniate teeth; appendages sometimes present on keel on one or both sides, orbicularoblong; lobules broadly ovate, $2 / 3-1 / 2 \times$ lobe length, apex apiculate to bifid; appendages sometimes present at the middle of basal part, orbicular-oblong; bracteoles spathulate, apex emarginate to bifid, $1 / 2 \times$ bracteole length with triangular teeth, the teeth consisting of 3-7 cells, 2-3 cells wide at base and ending in a row of 1-2 cells, margins plane or recurved, central region gibbous. Perianths exserted to $1 / 2$, obovate or oblong-cylindrical, 2.5-2.6 $\times$ 1.1-1.3 mm, apex truncate, surface sharply 3-keeled, keels in upper 1/3 with numerous laciniate or triangular teeth (entire in T. montanus and subg. Mastigolejeunea); appendages on basal port of keel or not developed; beak 3-5(-7) cells long. Calyptra entirely enveloping the young sporophyte, 1-2 stratose, outer cells larger than inner cells. Sporophyte exerted up to $2.5 \mathrm{~mm}$ above the perianth; foot 5-6 transversal cell rings; setae 22-25 cells long, nonarticulate, with 16 outer rows of cells and 4 inner row; capsules globose, dark-brown, 0.2-0.3 $\mathrm{mm}$ in diameter, dehiscing from the apex downward into 4 valves, valves recurved $3 / 4$ of their length, with a rectangular-shaped hinge, inner valve surfaces covered by a yellow-brown, monofenestrate or plurifenestrate layer of thickening; elaters linear, 350-550 × 12-20 $\mu \mathrm{m}$, with one brown spiral band, 66 (in subg. Thysananthus) or 72 (in subg. Mastigolejeunea) per capsule, attached to both surface and margins of valve in " $1+3+5+6$ " or " $2+4+6+6$ " pattern (in subg. Thysananthus, unknown in subg. Mastigolejeunea), elateroids absent; spores subisodiametric to oblong, surface with numerous bluntish papillae, 1-4 rosettes per facet, rosettes with 5-8 sharp, smooth papillae, $8-12 \mu \mathrm{m}$ in diameter. Sporelings of the Lopholejeunea-type. Vegetative reproduction absent.

Chromosome number. $\mathrm{n}=9$ (in Thysananthus aculeatus and T. spathulistipus), $\mathrm{n}=8+$ m (in T. floreus) (Fritsch, 1991).

Chemistry. Sesquiterpenoids, unidentified diterpenoids, flavonoids, stigmasterol and aromatic hydroxy acids (Gradstein et al. 1985, Kruijt et al. 1986, Harinantenaina et al. 2006, Sukkharak et al., in press).

Distribution and ecology. Pantropical, ranging in altitude from sea level up to $3100 \mathrm{~m}$ in Papua New Guinea. The centre of diversity is in Southeast Asia. All species are epiphytes 
(not epiphyllous), growing on stems or twigs of living trees or decaying wood in logging areas, along roadsides, in cultivated areas (plantations, gardens, etc), savannas, rain forests and montane forests. Occurrence on rock along stream, coastal forests and in mangrove forests is very rare.

\section{KEY TO THE SUBGENERA, SECTIONS AND SECTIONS OF THYSANANTHUS}

1. Perianth toothed (except T. montanus) .subg. Thysananthus 2

2. Leaf lobe without vitta. sect. Thysananthus 3

3. Stem with epidermal cells as large as medulla cells (except $T$. combinatus). Underleaf bases free or adnate with leaves on one side. Margins of female bracts and bracteoles and bracteoles toothed. ser. Thysananthus

3. Dorsal epidermis cells of stem larger than inner cells. Underleaf bases adnate with leaves on one side. Margins of female bracts and bracteoles entire. ser. Anguiformes

2. Leaf lobe with vitta. sect. Dendrolejeunea 4

4. Plants dendroid, with creeping stoloniform stems and ascending leafy stems. Branching of leafy stems regularly pinnate. Lobule bases without appendage. ser. Dendrolejeunea

4. Plants with projecting growth and irregularly pinnate branching. Lobule bases with appendages. ser. Sandeanthus

1. Perianth entire. subg. Mastigolejeunea

\section{ARTIFICIAL KEY TO THE SPECIES OF THE GENUS THYSANANTHUS}

1. Leaf lobe without vitta.

2. Leaf margins entire.

3. Underleaf bases with well-developed auricles. T. discretus

3. Underleaf bases without well-developed auricles. 
4. Leaves when moist weakly concave, apical parts plane, not recurved.

5. Underleaves toothed.

6. Dorsal base of leaves auriculate. Underleaves obovate. Perianth teeth laciniate, $4-5$ cells long. Paleotropical

T. comosus

6. Dorsal base of leaves not auriculate. Underleaves spathulate. Perianth teeth triangular, 1-3 cells long. Neotropical. T. amazonicus

5. Underleaves entire.

7. Dorsal epidermis cells of stem not larger than inner cells. Female bracteole apex bifid. Tropical Africa. T. floreus

7. Dorsal epidermis cells of stem larger than inner cells. Female bracteole apex roundedtruncate. Tropical America, Asia.

8. Lobules with (2-)3-5 teeth.

9. Male bracts at base of spike larger than at apex. Paleotropical. T. integrifolius

9. Male bracts small throughout spike. Neotropical, rare T. innovans

8. Lobules with (0-)1 tooth.

10. Lobule teeth elongate, 3-6 cells long.

11. Lobules $1 / 2 \times$ leaf length T. calcaratus

11. Lobules $1 / 4-1 / 3 \times$ leaf length.

12. Leaves oblong, leaf apex acute-apiculate.

T. undulatus

12. Leaves ovate, leaf apex rounded T. virens

10. Lobule teeth triangular, 1-2 cells long.

13. Leaf margins recurved

14. Leaf margins undulate. T. truncatus 
14. Leaf margins not undulate.

13. Leaf margins not recurved.

15. Leaf apex acute-apiculate. T. repletus

15. Leaf apex rounded or obtuse

16. Leaves rounded-ovate, less than $1.5 \times$ longer than wide

17. Stem rigid, stem eipidermal cells thick-walled. Perianths 3-keeled. T. humilis

17. Stem fragile, stem epidermal cells thin-walled. Perianths10-keeled in upper half T. reconditus

16. Leaves oblong, more than $1.5 \times$ longer than wide

18. Male bract lobules epistatic, distant from each other. Paleotropical T. ligulatus

18. Male bract lobules hypostatic, imbricate. Neotropical

19. Underleaves squarrose. Perianth with a sharp ventral keel, subsidiary folds lacking. South America except Amazonia. T. auriculatus

19. Underleaves flat. Perianth with swollen ventral keel and subsidiary folds. Northern South America T. plicatiflorus

4. Leaves when moist strongly concave, apical parts turn to ventral side, recurved.

20. Underleaves spathulate, entire or slightly toothed. Dorsal epidermis cells of stem not larger than inner cells T. gottschei

20. Underleaves obovate, entire. Dorsal epidermis cells of stem larger than inner cells.

21. Dorsal base of leaves not auriculate. Perianth teeth triangular, 1-2 cells long T. anguiformis

21. Dorsal base of leaves auriculate. Perianth teeth laciniate, 2-7 cells long.

22. Lobule teeth triangular, 1-3 cells long. New Caledonia T. pancheri 
2. Leaf margins toothed.

23. Leaves symmetric.

24. Lobule keel on one side of the stem with a foliar appendage (on the side where leaves and underleaves are free) T. appendiculatus

24. Lobule keel without foliar appendage T. spathulistipus

23. Leaves asymmetric.

25. Underleaf bases with well-developed auricles. T. discretus

25. Underleaf bases without well-developed auricles.

26. Leaves when moist strongly concave, apical parts turn to ventral side, recurved. Underleaves spathulate. T. convolutus

26. Leaves when moist weakly concave, apical parts plane. Underleaves obovate.

27. Dorsal base of leaves auriculate. Underleaves flat. Perianth teeth laciniate, 4-5 cells long T. comosus

27. Dorsal base of leaves not auriculate. Underleaves channeled/hollow. Perianth teeth triangular, 1-2 cells long

T. aculeatus

1. Leaf lobe with vitta.

28. Branching regularly pinnate. Stoloniform creeping stems present. T. fruticosus

28. Branching irregularly pinnate or branches lacking. Stoloniform creeping stems lacking.

29. Leaves when dry widely spreading, loosely reflexed or plane. Leaf cells (except for vitta) subisodiametric. T. retusus

29. Leaves when dry convolute. Leaf cells elongate.

30. Leaves lanceolate, toothed (rarely entire). Leaves when dry laterally appressed to the stem or convolute. Perianth teeth triangular, 1-2 cells long T. mollis 


\section{Thysananthus subgenus Thysananthus}

Perianth toothed (except T. montanus).

Type species: Thysananthus comosus Lindenb.

Distribution: tropical America, Africa, Indochina, Malesia, Australia, Pacific.

\section{Thysananthus section Thysananthus}

Leaves without vitta.

For distribution see under subg. Thysananthus.

\section{Thysananthus series Thysananthus}

Stem with epidermal cells as large as medulla cells (except $T$. combinatus). Underleaf bases free or adnate with leaves on one side. Margins of female bracts and bracteoles toothed.

For distribution see under subg. Thysananthus.

\section{Thysananthus aculeatus Herzog (Figs. 7-8)}

Ann. Bryol. 4: 89. 1931; Verdoorn (1934: 174); Mizutani (1961: 153; 1969: 137;

1977: 135)._-Type: PhILIPPINES. Luzon: Mt. Banahao, 20 XII 1913, Baker 7079, (lectotype, here designated: JE!; isolectotypes: PC!, U!). PHILIPPINES. Luzon: Mt. Banahao, 20 XII 1913, Baker 7083 (paralectotype: JE!).

Thysananthus formosanus Horik., J. Sci. Hiroshima Univ., Ser. B, Div. 2, Bot. 2:

252. 1934.-Type: TAIWAN. Taito: between Shinsuiei and Shucho-kyokai, 3 I 1933, Y. Horikawa 10622 (holotype: HIRO!).

Thysananthus richardsianus Verd., Ann. Bryol. Suppl. 4: 173. 1934.-Type:

MALAYSIA. Sarawak: “G. Balapau, Ulu Tinjar, in silvis et ad arb. truncos, $750 \mathrm{~m}$,

XI 1932”, P. Richards s.n., Hep. Sel. Crit. Verdoorn 398 (holotype: FH!; isotypes: BM!, BM-K!, BR!, C!, G! 2 packets, JE!, L! 2 packets, NY!, PC!, S!, U!, W!).

Plants autoicous, with projecting growth, turning upwards and becoming ascending to erect, yellowish brown to dark brown in herbarium specimens, up to $3.5 \mathrm{~cm}$ long $\times 1-1.8 \mathrm{~mm}$ wide. Stems rather rigid; ventral merophyte 9-10 cell rows wide; in cross section roundorbicular in shape, 200-211 $\mu \mathrm{m}$ high $\times 160-180 \mu \mathrm{m}$ wide, composed of 38-42 epidermal 
cells surrounding 103-121 medullary cells in 10-14 layers high, epidermal cells not larger than medullary cells. Leaves imbricate, when dry suberect and convolute, when moist weakly concave, apical parts plane, not recurved; dorsal lobe asymmetrically ovate, $0.8-1 \times 0.5-0.7$ $\mathrm{mm}$, apex obliquely acute, dorsal base cordate, dorsal margin with 4-7 triangular teeth, the teeth consisting of 3-4 cells, being 2-3 cells wide at base, apex of one cell, ventral margin slightly upcurved, with 12-13 triangular teeth, the teeth consisting of 3-5 cells, being 2-3 cells wide at base, apex of one cell; cells elongate-hexagonal with acute ends, vitta cells absent, marginal cells 7-12 × 7-10 $\mu \mathrm{m}$, median cells $22-35 \times 7-10 \mu \mathrm{m}$, basal cells $25-50 \times$ 10-22 $\mu \mathrm{m}$, trigones cordate, often coalesced, intermediate thickenings 0-2 per cell wall; oil bodies 3-4 per cell (Mizutani, 1961). Lobules oblong-rectangular, 0.2-0.3 × 0.1-0.2 mm, 1/4-1/3× lobe length; appendage on surface of lobule base not developed; keel without appendage; lobule apex transverse, not or shortly continuing into the ventral lobe margin, apex with one triangular tooth, the teeth consisting of 4-6(-36 in Baker 7083) cells, being 2-6 cells wide at base and ending in a row of (1-)2-3 cells. Underleaves imbricate, channeled or hollow, obovate, $0.5-0.6 \times 0.4-0.5 \mathrm{~mm}, 3-4 \times$ stem width, apex truncate, plane, with 8-15 triangular teeth, the teeth consisting of 3-4 cells, being 2 cells wide at base, apex of one cell, bases cuneate, underleaf bases adnate with leaves on one side, on left-hand side for right branches and right-hand side for left branches; cells 13-20 × 7-10 $\mu \mathrm{m}$. Androecia terminalintercalary on lateral branches, bracts and bracteoles in 3-12 pairs, bracts hypostatic, 0.7-0.8 $\times 0.5-0.6 \mathrm{~mm}$, apex acute, margins entire; antheridia 2 per bract. Gynoecia with 2 lejeuneoid innovations forming a dichasial pattern; lobe ovate, 0.5-1.4 $\times 0.3-0.7 \mathrm{~mm}$, apex apiculate, margins in upper $1 / 3$ with triangular teeth, the teeth consisting of 3-5 cells, being 2-3 cells wide at base, apex of one cell; lobules broadly ovate, $1 / 2-2 / 3 \times$ lobe length, apex apiculate, margins with triangular teeth, the teeth consisting of 3-5 cells, being 2-3 cells wide at base and ending in row of 1-2 cells; bracteoles spathulate, $1.2-1.3 \times 0.7-0.8 \mathrm{~mm}$, apex emarginate, $1 / 3 \times$ bracteole length with triangular teeth, the teeth consisting of 3-5 cells, being $2-3$ cells wide at base, apex of one cell, margins plane. Perianths oblong-cylindrical, 1.7-1.8 $\times 0.7-0.8$ $\mathrm{mm}$, keels in upper 1/3 with triangular teeth, the teeth consisting of 3-5 cells, being 2-3 cells wide at base and ending in a row of 1-2 cells; beak $53-71 \mu \mathrm{m}$ with 3 cells long.

Chromosome number. $\mathrm{n}=9$ (Fritsch, 1991).

Chemistry. Unknown.

Additional illustrations. Herzog (1931, p. 88, Fig. 3); Horikawa (1934, p. 20, Figs. 110 as Thysananthus formosanus); Mizutani (1961, p. 154, Fig. VI. 1-23). 
Distribution and ecology. Southern Japan, Taiwan, Malaysia and Philippines; 200$2350 \mathrm{~m}$; on moist rocks along streams and on bark of trees in the understory of rain forests and montane forests.

RePresentative SPecimens. Japan. Kagoshima: Amami Ōshima, Kawauchi River, 1 Dec 1988, Inoue s.n. (BR, C, G, L, PC, S, U); Suzukawa near Onoaida, Mizutani 10313, 10372 (L, S); Miyanoura, Jul 1951, Amakawa s.n. (C, L, S, W); along Hana-age river, Tagawa \& Kitagawa 561 (S, W); along Odagumi river, Tagawa \& Kitagawa 939 (S, W); Yakushima, Faurie 750 (BM, G); Yakushima, Jul 1900, Faurie s.n. (PC).-OKINAWA: Ryukyu Islands, Oogimi, 28 Jan 1955, Amano s.n. (BM, BR, C, G, L, S, W). Taiwan. the type of Thysananthus formosanus, Horikawa 10642 (HSNU) (J. Wang, pers. comm.).

Malaysia. SARAWAK: the type of Thysananthus richardsianus. Philippines. BENGUET: Baguio, Mt. Santo Tomas, Onraedt 84.P.10959 (BR, JE), Aptroot $20370 a$ (U).- LAGUNA AND Quezon: the type.-Oriental Mindoro: Mt. Halcon, "Dhenill 5709a” (G), Salgado 88.P.12142 (BR).-ZAMBALES: without location, Dec 1907, Curran \& Merrit s.n. (G).

Gradstein et al. (2002) treated Thysananthus aculeatus as a synonym of $T$. spathulistipus whereas Verdoorn (1934) treated the two taxa as separate species. The difference between both taxa was discussed by Verdoorn (1.c.). Based on examination of a number of collections, I found that the asymmetrical leaves (symmetrical in T. spathulistipus), lobule apex transverse, not or shortly continuing into the ventral lobe margin (lobule apex oblique, longly continuing into the ventral lobe margin in $T$. spathulistipus) and channeled/hollow obovate underleaves (spathulate in $T$. spathulistipus) in T. aculeatus are sufficiently distinct to keep both taxa separate.

Thysananthus aculeatus was described by Herzog in 1931 based on two specimens, Baker 7079 and 7083. The two specimens are different in the number lobule tooth cells (4-6 cells in specimen nr. 7079 while 12-36 cells in nr. 7083). In the original description, the variation in lobule teeth was not mentioned, however, the original figure of the lobule teeth was drawn from specimen nr. 7079 only. I have chosen the latter specimen as the lectotype of this species because it is good material with perianths.

Mizutani (1961) considered Thysananthus formosanus and T. richardsianus as a synonym of T. aculeatus. In addition, he showed that the difference between T. aculeatus and T. richardsianus is only the size of the first tooth of the leaf-lobule. Variation in shape and size of the teeth of the leaf-lobule is common and is also seen in, e.g., Spruceanthus semirepandus (Nees) Verd., Leucolejeunea xanthocarpa (Lehm. \& Lindenb.) A. Evans, 
Cheilolejeunea imbricate (Nees) Steph., etc. In the present study it appeared that $T$. formosanus is somewhat intermediate between T. aculeatus and T. richardsianus, having the appearance and innovation pattern like in T. aculeatus and the curved, elongate lobule teeth of T. richardsianus. I, therefore, treat them all as one species and reduce $T$. formosanus and $T$. richardsianus to a synonym of $T$. aculeatus. The type of $T$. richardsianus was distributed by Verdoorn in his exsiccata series (F. Verdoorn (ed.), Hep. Sel. Crit. VIII: 398) and the label data of the exsiccata are slightly different from the specimen data in the original publication.

\section{Thysananthus amazonicus (Spruce) Schiffn. (Fig. 9)}

in Engler \& Prantl, Nat. Pflanzenfam. 1, 3:130. 1893; Stephani (1912: 784); Fulford (1941: 37); Gradstein (1994: 84). Lejeunea (subg. Thysanolejeunea) amazonica Spruce, Trans. \& Proc. Bot. Soc. Edinburgh. 15: 106. 1884.-Type: BRAZIL. Pará: Spruce s.n. (lectotype, designated by Fulford, 1941: MANCH; isolectotypes: G, MANCH, NY, fide Gradstein, 1994).

Plants paroicous and autoicous, with projecting growth, turning upwards and becoming ascending to erect, or project downwards and becoming pendent, green to dull brown in the field, yellowish to reddish brown in herbarium specimens, up to $1.6 \mathrm{~cm}$ long $\times$ 2-2.9 mm wide. Stems rather rigid; ventral merophyte 7-9 cell rows wide; in cross section round-orbicular in shape, 175-188 $\mu \mathrm{m}$ high $\times 161-167 \mu \mathrm{m}$ wide, composed of 29-32 epidermal cells surrounding 63-73 medullary cells in 12-14 layers high, epidermal cells not larger than medullary cells. Leaves imbricate, when dry suberect and convolute, when moist weakly concave, apical parts plane, not recurved; dorsal lobe asymmetrically oblong-falcate, 1.2-1.7 × 0.6-1 mm, apex apiculate, margin entire, dorsal base cordate, ventral margin upcurved 1/2× leaf length; cells elongate-hexagonal with acute ends, vitta cells absent, marginal cells 5-7.5 × 7.5-12.5 $\mu \mathrm{m}$, median cells $15-27.5 \times 7.5-10 \mu \mathrm{m}$, basal cells 50-70 $\times$ 10-22 $\mu \mathrm{m}$, trigones cordate, often coalesced, intermediate thickenings 0-2(-3) per cell wall; oil bodies (3-)4-6 per cell. Lobules oblong-rectangular, $0.2-0.5 \times 0.1-0.2 \mathrm{~mm}, 1 / 5-1 / 3 \times$ lobe length; appendage on surface of lobule base not developed; keel without appendage; lobule apex oblique, longly continuing into the ventral lobe margin, apex entire or with $1(-2)$ triangular teeth, the first tooth consisting of 3-6 cells, being 2-3 cells wide at base and ending in a row of 1-2 cells, the second tooth consisting of 3-5 cells, being 1-2 cells wide at base and ending in a row of 1-2 cells, often obsolete. Underleaves imbricate, slightly squarrose, broadly spathulate, $0.7-1 \times 0.5-0.9 \mathrm{~mm}, 3-4 \times$ stem width, apex emarginate-lunulate, plane, 
with 8-12 triangular teeth, the teeth consisting of 7-9 cells, being 2-3 cells wide at base, apex of one cell, bases cuneate, underleaf bases adnate with leaves on one side, on left-hand side for right branches and right-hand side for left branches; cells 15-20 $\times$ 5-8 $\mu \mathrm{m}$. Androecia below the gynoecium or terminal-intercalary on lateral branches, bracts and bracteoles in 2-8 pairs, bracts epistatic or hypostatic, $0.8-1 \times 0.3-0.5 \mathrm{~mm}$, apex acute, margins entire; antheridia 2 per bract (Gradstein, 1994: 1-2 antheridia). Gynoecia with one lejeuneoid innovation forming a monochasial pattern; lobe ovate, $1.3-1.5 \times 0.6-0.8 \mathrm{~mm}$, apex apiculate, margins in upper $1 / 3$ with triangular teeth, the teeth consisting of 3-5 cells, being 2-3 cells wide at base and ending in a row of 1-2 cells; lobules broadly ovate, 1/2-2/3× lobe length, apex apiculate to slightly bifid, margin with triangular teeth, the teeth consisting 3-5 cells, being 2-3 cells wide at base and ending in a row of 1-2 cells; bracteoles spathulate, 1.1-1.4 $\times$ $0.5-0.7 \mathrm{~mm}$, apex emarginate to short bifid, $1 / 3 \times$ bracteole length with $12-14$ triangular teeth, the teeth consisting of 3-7 cells, being 2-3 cells wide at base and ending in a row of 1-2 cells long at apex, margins recurved. Perianths oblong-cylindrical, 1.4-1.7 $\times 0.6-0.8 \mathrm{~mm}$, keels in upper 1/3 with triangular teeth, the teeth consisting of 3-5 cells, being 2-3 cells at base and ending in a row of 1-3 cells; beak 300-600 $\mu \mathrm{m}$ with 3-4 cells long.

Chromosome number. Unknown.

Chemistry. Cadinane sesquiterpenoids, diterpene acetates as major components and sterols (Gradstein et al., 1985).

Additional illustrations. Fulford (1941, p. 38, Figs. 28-40); Gradstein (1994, p. 85, Fig. 23).

Distribution and ecology. Tropical America (Colombia, Amazonian part of Brazil, Venezuela, Trinidad and Guianas; disjunct in Costa Rica and eastern Cuba); from sea level to about $1000 \mathrm{~m}$; on branches, twigs, trunks or lianas, occasionally on logs, in marsh forest, swamp forest, evergreen forests on white sand, and savannas; usually in the forest canopy.

RePresentative Specimens. Martinique. La Trinité: Basse Comté, Cremers 5557 (BR). Costa Rica. LIMÓN: Tortuguero, Cleef \& Kapelle s.n. (GOET), Timme 11158 (GOET). Colombia. Amazonas: Rio Caqueta TRA $12 \mathrm{~km}$, Mohr \& Sosa 20 (U). Venezuela. Bolívar: Cerro Guaiquinima, Sipman 26654, 26678 (U). Guyana. CUYUni-MaZARUni: Essequibo river, Richards 510 (BM-K, GOET), 188 (BM-K).-DEMERARA-MAHAICA: Timehri, Thomson's farm, Gradstein 4709 (G, GOET), Cornelissen \& ter Steege C017 (U).UPPER DEMERARA-BerbiCE: Mabura hill, Cornelissen \& ter Steege C111, C679, C680, C681, C682, C743, C744, C761, C762, C829, C860, C861 (U).--UPPER MAZARUNI: North slope of Mt. Roraima, Gradstein 5151 (G, U); Waruma river, Gradstein 4993 (G, U); Mt. Latipu, 
Gradstein 5560, 5650 (U); Waramadan, trail to Mt. Pwipwi, Gradstein 5693 (BR, G, U); Jawalla, at confluence of Kukui river and Mazaruni river, Gradstein 4835, 4911 (U), 4857 (G, U). Suriname. NICKERIE: Nickerie, area of Kabalebo dam project, Bekker 1086a, 1090, $1160 b, 1164 b, 1166,1174,1176,1177,1195,1296,1343,1346 b, 1361 a, 1375,1387,1427 b$, $1459,1471,1475,1483 b, 1494 b, 1514,1522 b, 1526 b, 1530,1554,1555,1749 c, 1756 a(\mathrm{U})$, Florschütz-de Waard \& Zielman 5187A, 5189A, 5529A (U); Jodensavanne-Mapane kreek area, Lindeman 3937 (GOET; PC); Marchal creek, Gradstein s.n. (GOET).-CSIPALIWINI: Blanche Marie valley, Muñoz 98-19 (GOET). French Guiana. CAYENNE: Trésor reservation, Hartmann \& al. 04-052 (GOET); Montagne de Kaw, Hartmann \& al. 04-117, 04-118 (GOET), Cornelissen \& ter Steege C0265, C0311 (U), Gradstein 5900 (U); forest between savanna one and "petit savanna", Hartmann \& al. 04-120, 04-121, 04-123 (GOET); Emerald Jungle village, Holz FG00-51A, FG00-55 (GOET); bridge over Comté river, Gradstein 6658 (U); Montsinery, along "Risque tout" forest track, Gradstein 5793 (U); Saül, along La Fumée trail, Gradstein 6131 (U), Aptroot 15381, 15447 (U), Montfoort \& Ek 1164, 1165, 1166, 1167, 1168, 1169 (U).--SAINT-LAURENT-DU-MARONI: Charvein, 20 Jan 1914, Benoist s.n. (PC); along trail from St. Laurent to Apatoa, Cornelissen \& ter Steege C0270 (U). Brazil. AmAZONAS: Lages river, Vital \& Yano 718 (U); Manaus, Reserve Experimental do INPA, Prance \& al. 18714 (U); Tarumã Fälle, Schäfer-Verwimp \& Verwimp 9815 (BR); along Manaus-Caracaraí road, 8 Jul 1974, Vital \& al. s.n. (U); ibid., 13 Nov 1973, Berg \& al. P19514 (U); Caqueta river, Mohr \& Sosa 20 (GOET); Trombetas river, Campbell \& al. P22268 (U), Prance \& al. 22208 (U); Madeira river, Ule 585 (G); Juruú river, Ule $338(\mathrm{G})$; Rio Negro, Ule $571(\mathrm{G})$.—PARÁ: the type.

Reported from Cuba (Holguin and Guantánamo), Trinidad (East of Sangre Grande) and Venezuela (Amazonas) by Gradstein (1994).

Thysananthus amazonicus often grows more or less pendent, especially when occurring on small branches or twigs (Gradstein, 1994). The leaf lobules of T. amazonicus may have one or two teeth and sometimes there is no tooth at all. According to Gradstein (1994) the leaf lobule is usually $1 / 4$ or less the length of the leaf but in some Cuban specimens the lobules may be slightly larger, up to $1 / 3 \times$ leaf length.

Thysananthus amazonicus is morphologically most closely related to the Asiatic $T$. comosus, from which it is readily distinguished by (1) slightly squarrose spathulate and emarginate-lunulate underleaves (flat obovate and truncate in T. comosus), (2) monoicous (dioicous in T. comosus), (3) epistatic or hypostatic male bract lobules (hypostatic in $T$. comosus), and (4) triangular perianth teeths, 1-3 cells long (laciniate, 3-6 cells long in $T$. 
comosus). Thysananthus amazonicus may also be confused with T. spathulistipus. However, T. spathulistipus differs by toothed (sometimes entire) leaf margin, truncate underleaves, hypostatic male bract lobules and occurrence in paleotropics.

Along the Rio Caqueta, Colombia, Thysananthus amazonicus is called "lama" and is used as a painkiller against snake and scorpion poisoning (Mohr \& Sosa, in sched.; fide Gradstein, 1994).

\section{Thysananthus appendiculatus Steph. (Fig. 10)}

Sp. Hepat. 4: 794. 1912; Mizutani \& Piippo (1986: 484); Gradstein et al. (2002: 70). Thysanolejeunea appendiculata Steph., Hedwigia 35: 138. 1896, nom. inval.-Type: PAPUA NEW GuINEA. Western: Fly River Branch, Bäuerlein 85 (lectotype, designated by Verdoorn, 1934: G!); Icon. Steph. nr. 10166.

Plants dioicous, with projecting growth, turning upwards and becoming ascending to erect, yellowish brown in herbarium specimens, up to $2.5 \mathrm{~cm}$ long $\times 2-2.2 \mathrm{~mm}$ wide. Stems rather rigid; ventral merophyte 9-12 cell rows wide; in cross section round-orbicular in shape, 228-260 $\mu \mathrm{m}$ high $\times 188-250 \mu \mathrm{m}$ wide, composed of 41-55 epidermal cells surrounding 95118 medullary cells in 13-14 layers high, epidermal cells not larger than medullary cells. Leaves imbricate, when dry suberect and convolute, when moist weakly concave, apical parts plane, not recurved; dorsal lobe symmetrically oblong-falcate, 1.1-2.5 × 0.8-1.4 mm, apex apiculate, dorsal base auriculate, auricle $77-225 \times 75-250 \mu \mathrm{m}$, dorsal margin with 3-5 triangular teeth, the teeth consisting of 3-7 cells, being 2-3 cells wide at base and ending in a row of 1-2 cells, ventral margin upcurved $1 / 2 \times$ leaf length with 8-10 triangular teeth, the teeth consisting of 3-8 cells, being 2-3 cells wide at base and ending in a row of 1-2 cells; cells elongate-hexagonal with acute ends, vitta cells absent, marginal cells 7-13 $\times 5-8 \mu \mathrm{m}$, median cells $17-35 \times 5-10 \mu \mathrm{m}$, basal cells $30-57 \times 12-15 \mu \mathrm{m}$, trigones cordate, often coalesced, intermediate thickenings $0-1$ per cell wall; oil bodies unknown. Lobules oblongrectangular, $0.4-0.5 \times 0.1-0.2 \mathrm{~mm}, 1 / 5-1 / 3 \times$ lobe length; appendage on surface of lobule base not developed; keels with appendages on one side where leaves and underleaves are free and opposite to adnate ones; lobule apex oblique, longly continuing into the ventral lobe margin, apex with 1(-2) triangular teeth, the first tooth consisting of 3-6 cells, being 2-3 cells wide at base and ending in a row of 1-2 cells, the second tooth of one cell only, often obsolete. Underleaves imbricate, slightly squarrose, broadly spathulate, $0.9-2.2 \times 0.5-0.9 \mathrm{~mm}, 3-4 \times$ stem width, apex truncate to emarginate, plane, with 9-11 triangular teeth, the teeth consisting 
of 3-6 cells, being 2-3 cells wide at base, apex of one cell, bases cuneate or auriculate, underleaf bases adnate with leaves on one side, on left-hand side for right branches and righthand side for left branches; cells 15-20 × 5-7 $\mu \mathrm{m}$. Androecia terminal-intercalary on lateral branches, bracts and bracteoles in 4-13 pairs, bracts hypostatic, 0.6-0.9 ×0.4-0.6 mm, apex acute, margins entire; antheridia 2 per bract. Gynoecia with 2 lejeuneoid innovation forming a dichasial pattern; lobe ovate, 2.2-2.4 × 1-1.1 mm, apex apiculate, margins in upper 1/3 with triangular teeth, the teeth consisting of 3-8 cells, being 2-3 cells wide at base and ending in a row of 1-3 cells; lobules broadly ovate, 1/2× lobe length, apex apiculate, margin with triangular teeth, the teeth consisting 3-5 cells, being 2-3 cells wide at base and ending in a row of 1-2 cells; bracteoles spathulate, 1.8-1.9 × 0.9-1.1 mm, apex emarginate, 1/3× bracteole length with triangular teeth, the teeth consisting of 3-7 cells, being 2-3 cells wide at base and ending in a row of 1-2 cells, margins slightly recurved. Perianths oblongcylindrical, 1.9-2.1 ×0.8-0.9 mm, keels in upper $1 / 3$ with numerous laciniate teeth, with $2-4$ cells long at apex; beak 62-65 $\mu \mathrm{m}$ with 5 cells long.

Chromosome number. Unknown.

Chemistry. Six flavonoids and six aromatic hydroxy acids (Kruijt et al., 1986).

Distribution and ecology. Endemic to Western Melanesia: Western New Guinea (Indonesia) and Papua New Guinea; 400-2600 m; on trunks, branches, large vines, stems of treelets in old garden sites, grasslands with regrowth species, understory of rain forests (secondary forests) and montane forests.

Representative Specimens. Indonesia. Western New Guinea: Papua, Cycloop Mts., Royen \& Sleumer 6006 (JE, L); West Papua, Arfak Mts., Beccari s.n. (JE, L). Papua New Guinea. Central: K. B. Sawmill, Streimann \& Naoni 16567 (JE).-EASTERN Highland: Daulo Pass, Streimann 18124 (JE), Streimann \& Bellamy 18093 (JE), Streimann \& Kairo 18138 (LAE); track to Mt. Michael, Streimann 18807 (JE)._GULF: Bema-Kaintiba road, Streimann 33647 (JE).--MorobE: Wau, Mt. Kaindi, Gradstein 3875 (U), Streimann 22497 (LAE); Kunai Creek, Gradstein 3962 (G); Ogeramnang, Clemens 5414 (JE, PC, S, W); Slate creek \& Gumi creek divide, Streimann 13829, 13834 (JE), 13826, 13838 (LAE), 13859 (JE, LAE); Bulolo-Watut divide, Streimann 25022 (JE); Kaisenik logging area, Shea 6336 (JE); Upper Watut river, Streimann 23092 (JE); Aseki-Bulolo road, Streimann 23191, 26124 (JE, LAE), 23195 (LAE); Pouyu village, Streimann \& Tamba 12674 (JE, LAE); Oomsis logging area, Streimann 25836 (JE); Aiuwa-Bakia track, Streimann \& Tamba 12358 (JE, LAE), 12276, 12362, 12377, 12413 (LAE).-SIMBU: Dirima mission, Toia 171 (LAE).SOUTHERN HighlANDS: Margarima-Tari road, Streimann 24378, 24388 (JE, LAE, W); Onim 
forestry station, Streimann 24628, 24740 (JE); Komo-Tari road, Streimann 32618, 32631 (JE); Kengaput, Streimann 26902 (JE), 23702 (LAE); Lama Sawmill logging area, Streimann 26422, 26562 (JE); Tari gap, Streimann 32730 (JE).-WESTERN: the type.-WeSTERN Highland: Kum Magei Mts., Streimann 20679 (JE, LAE).

The most outstanding character of Thysananthus appendiculatus is the foliar appendage which is developed on the keels of leaves on one side of the stem only, on the side where leaves and underleaves are free and opposite to adnate ones. This character is otherwise only found in T. anguiformis, T. convolutus var. laceratus, $T$. discretus, $T$. fruticosus and $T$. gottschei var. continuus. Differences are discussed under T. discretus. Thysananthus appendiculatus is closely related to $T$. spathulistipus; the latter species differs essentially by the absence of the appendage and by the triangular perianth teeth with 1-2 cells long.

The epithet "appendiculatus" is derived from the foliar appendage which is found on the keels of leaves as described by Stephani in the original description. The original drawing of Thysananthus appendiculatus in Stephani's "Icones Hepaticarum Ineditae" is erroneous in showing a foliar appendage on both sides of stems. The shown left-hand side appendages are probably parts of the dissected underleaves. Note that the illustration of the species in Gradstein et al. (2002: Fig. 44) does not show the foliar appendage.

\section{Thysananthus combinatus sp. nov. (Fig. 11)}

Type. MALAYSIA. Perak: Taiping, on old planted trees in park around Taiping lake at the foot of Maxwell Hill, ca 50 m, on tree buttress, 9 Mar 2004, Gradstein et al. 10366 (holotype: GOET!). The epithet combinatus refers to the occurrence of characters of ser. Thysananthus and ser. Anguiformes in this species.

Cellulae epidermales dorsales dilatatae. Amphigastria integra. Lobuli dentis elongatis 4-6 cellulis longibus.

Plants dioicous, with projecting growth, turning upwards and becoming ascending to erect, dark brown in herbarium specimens, up to $1.4 \mathrm{~cm}$ long $\times 0.8-1.5 \mathrm{~mm}$ wide. Stems strongly rigid; ventral merophyte 8-9 cell rows wide; in cross section orbicular-subelliptic in shape, 137-200 $\mu \mathrm{m}$ high $\times 112-190 \mu \mathrm{m}$ wide, composed of 20-37 epidermal cells surrounding 31-93 medullary cells in 16-22 layers high, dorsal epidermal cells larger and somewhat thinner-walled than medulla and ventral epidermal cells. Leaves imbricate, when dry suberect and convolute, when moist concave, apical parts turn to ventral side, recurved; 
dorsal lobes asymmetrically ovate, $0.6-0.7 \times 0.5-0.6 \mathrm{~mm}$, apex apiculate, margin entire, dorsal base auriculate, ventral margin upcurved $1 / 2 \times$ leaf length; cells elongate-hexagonal with acute ends, vitta cells absent, marginal lobe cells 12-17 × 10-12 $\mu \mathrm{m}$, median cells

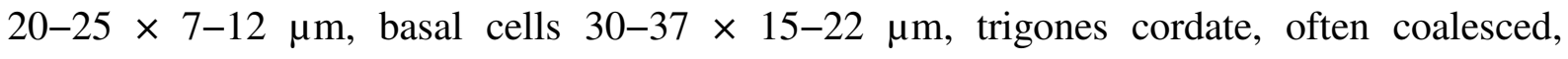
intermediate thickenings 0-1(-2) per cell wall; oil bodies unknown. Lobules rectangular, $0.2-0.3 \times 0.1-0.2 \mathrm{~mm}, 1 / 3 \times$ lobe length; appendage on surface of lobule base not developed, keel without appendage; lobule apex oblique, longly continuing into the ventral lobe margin, apex with one elongate tooth, the tooth consisting of 6 cells, being 2-3 cells wide at base and ending in a row of 4-5(-6) cells. Underleaves imbricate, slightly squarrose, broadly obovate, $0.4-0.5 \times 0.5-0.6 \mathrm{~mm}, 3-4 \times$ stem width, apex broadly rounded to truncate, plane, entire, bases cuneate, underleaf bases free or adnate with leaves on one side, on left-hand side for right branches and right-hand side for left branches; cells 17-20 × 7-10 $\mu \mathrm{m}$. Androecia terminal-intercalary on lateral branches, bracts and bracteoles in 8-10 pairs, bracts hypostatic, 0.6-0.7 $\times 0.3-0.4 \mathrm{~mm}$, apex acute, margins entire; antheridia 2 per bract. Gynoecia with 2 lejeuneoid innovations forming a dichasial pattern; lobe ovate, $0.9-1 \times 0.6-0.8 \mathrm{~mm}$, apex apiculate, margins in upper $2 / 3$ with laciniate teeth, the teeth consisting of 3-13 cells, being 2-3 cells wide at base and ending in a row of 2-5 cells; lobules broadly ovate, $2 / 3 \times$ lobe length, apex apiculate, margins with laciniate teeth, the teeth consisting of 3-10 cells, being 2-3 cells wide at base and ending in a row of 2-5 cells; bracteoles spathulate, $0.9-1 \times$ $0.7-0.8 \mathrm{~mm}$, apex emarginate, $2 / 3 \times$ bracteole length with laciniate teeth, the teeth consisting of 4-9 cells, being 2-3 cells wide at base and ending in a row of 2-6 cells, margins slightly recurved. Perianths oblong, $0.9-1 \times 0.6-0.7 \mathrm{~mm}$, keels in upper $1 / 3$ with numerous laciniate teeth, the teeth consisting of 5-11 cells, being 2-3 cells wide at base and ending in a row of 3-7 cells long; beak 30-50 $\mu \mathrm{m}$ with 3-4 cells long.

Chromosome number. Unknown.

Chemistry. Unknown.

Distribution and ecology. Known only from the type.

Thysananthus combinatus was previously identified as T. comosus and included in the molecular phylogenic analysis of Lejeuneaceae by Wilson et al. (2007a). It differs from typical $T$. comosus by its enlarged dorsal epidermis (epidermal cells as large as medulla cells in $T$. comosus), entire leaves and underleaves (sometimes toothed in T. comosus), elongate lobule teeth 4-6 cells long (0-1(-2) cells long in T. comosus), and underleaf bases only sometimes adnate with leaves (always adnate in T. comosus). The new species shares several characters with the member of ser. Thysananthus (toothed female involucres and perianths) 
and ser. Anguiformes (dorsal epidermal cells larger and somewhat thinner-walled than medulla and ventral epidermal cells), which suggests that it could represent an evolutionary link between these series. Moreover, T. combinatus may also be confused with T. retusus, which possesses elongate lobule teeth (4-6 cells long) as well. However, T. retusus differs by epidermal cells as large as medullary cells, isodiametric leaf cells, and presence of a vitta.

\section{Thysananthus comosus Lindenb. (Fig. 12)}

in Lehmann, Nov. Stirp. Pug 8: 25. 1844; Gottsche et al. (1845: 288); Stephani (1912: 787); Verdoorn (1934: 175); Fulford (1941: 39); Gradstein (1994: 87). Lejeunea comosa (Lindenb.) Mitt., J. Linn. Soc. Bot. 5: 109. 1861; Spruce (1884: 108, in subg. Thysanolejeunea).-Type: MALAYSIA. Penang: Pulo Penang, Wallich s.n. (lectotype, designated by Verdoorn, 1934: W; isolectotypes: BM!, $\mathrm{U} !)$.

Lejeunea (subg. Thysanolejeunea) dissoptera Spruce, Trans. \& Proc. Bot. Soc.

Edinburgh 15: 108. 1884. Thysananthus dissopterus (Spruce) Steph., Hedwigia 29: 4. 1890.-Type: "Guiana" ex hb. Hooker (holotype: MANCH; isotypes: BM, G, fide Gradstein, 1994).

Plants dioicous, with projecting growth, turning upwards and becoming ascending to erect, pale green, becoming dark brown in the older portion in the field, reddish brown in herbarium specimens, up to $2.8 \mathrm{~cm}$ long $\times 2 \mathrm{~mm}$ wide. Stems rather rigid; ventral merophyte 8-9 cell rows wide; in cross section round-orbicular in shape, 167-180 $\mu \mathrm{m}$ high $\times 130-148$ $\mu \mathrm{m}$ wide, composed of 25-27 epidermal cells surrounding 49-55 medullary cells in 8-12 layers high, epidermal cells not larger than medullary cells. Leaves imbricate, when dry suberect and convolute, when moist weakly concave, apical parts plane, not recurved; dorsal lobe asymmetrically ovate, $0.9-1 \times 0.7-0.9 \mathrm{~mm}$, apex obliquely mucronate, margins entire or serrate (Schiffner s.n.), dorsal base auriculate, auricle 112-137 × 75-88 $\mu \mathrm{m}$, ventral margin upcurved 1/2× leaf length; cells elongate-hexagonal with acute ends, vitta cells absent, marginal cells $10-20 \times 7.5-15 \mu \mathrm{m}$, median cells $22.5-30 \times 10-15 \mu \mathrm{m}$, basal cells $32.5-40 \times$ 15-22.5 $\mu \mathrm{m}$, trigones cordate, often coalesced, intermediate thickenings $0-1$ per cell wall; oil bodies 2-4(-5) per cell. Lobules oblong, $0.3-0.4 \times 0.1-0.2 \mathrm{~mm}, 1 / 4-1 / 3 \times$ lobe length; appendage on surface of lobule base not developed; keel without appendage; lobule apex oblique, longly continuing into the ventral lobe margin, apex entire or with 1(-2) triangular tooth, the first tooth consisting of 3 cells, being 2 cells wide at base, apex of one cell; the 
second tooth consisting of 3 cells, being 2 cells wide at base, apex of one cell, often obsolete. Underleaves imbricate, flat, broadly obovate, $0.5-0.6 \times 0.6-0.7 \mathrm{~mm}, 2-3 \times$ stem width, apex truncate, plane, entire to serrate, bases cuneate, underleaf bases adnate with leaves on one side, on left-hand side for right branches and right-hand side for left branches; cells 17-22 $\times$ 7.5-10 $\mu \mathrm{m}$. Androecia terminal-intercalary on lateral branches, bracts and bracteoles in 4-7 pairs (15-21 in Wood 1380), bracts hypostatic, 0.8-0.9 × 0.6-0.7 mm, apex mucronate, margins entire; antheridia 2 per bract. Gynoecia with one lejeuneoid innovations forming a monochasial pattern; lobe ovate, 1.1-1.3 $\times 0.7-1 \mathrm{~mm}$, apex apiculate, margin in upper $1 / 3$ with triangular teeth, the teeth consisting 3-5 cells, being 2-3 cells wide at base and ending in a row of 1-2 cells; lobules broadly ovate, 1/2× lobe length, apex apiculate to obscurely bifid, margin with triangular teeth, the teeth consisting of 5-6 cells, being 2-3 cells wide at base and ending in row of 2-3 cells; bracteoles spathulate, 1.1-1.2 $\times 0.7-0.8 \mathrm{~mm}$, apex emarginate, margin with triantular teeth, the teeth consisting 5-9 cells, being 2-3 cells wide at base and ending in a row of 2-3 cells, margins recurved. Perianths obovate, 0.9-1 × 1.3-1.4 mm long, keels in upper $1 / 2$ with numerous laciniate teeth with 3-6 cells long at apex; beak $2.5 \times 3 \mu \mathrm{m}$ with $4-5$ cells long.

Chromosome number. Unknown.

Chemistry. Cis- $\beta$-elemene, isolepidozene and unidentified sesquiterpenoid $\left(\mathrm{M}^{+}\right) 220$, 107(100), 43(80) (Sukkharak et al., in press).

Additional illustrations. Fulford (1941, p. 41, Figs. 41-51).

Distribution and ecology. Indomalesia; sea level up to $500 \mathrm{~m}$; on bark of living and fallen trees in the mangrove forests, rain forests (secondary forest), also on rock in coastal forests.

RePresentative Specimens. Seychelles. Beau Vallon: Dans Iles cliff walk, Norkett 18167 (BM); forest above Le Niol reservoir, Norkett 16584 (BM, JE).—GRAND' ANSE PRASLIN: Vallee de Mai Nature Reserve, Norkett 18426 (BM, JE), Pócs 9358/B (GOET).

India. ANDAMAN AND NICOBAR ISLANDS: Andaman islands, Port Blair, 1893, Man s.n., ex hb. Levier 740 (G); Nicobar Island, Katschall, 10 Feb 1975, Kurz s.n. (W 3 packets). Thailand. PAng NGa: Khao Luk National Park, Porn-Sook-Sawang 15 (BCU); Sri Pang Nga National Park, Chantanaorrapint 2121 (PSU); mangrove forest site 3, Boonkerd 5 (BCU); mangrove forest site 6, Thaithong 1130 (BCU).--NAKHON Si THAMMARAT: Mt. Khao Luang, Chantanaorrapint s.n. (PSU); Mt. Khao Nan Yai, Sukkharak 334 (BCU).-SongKLA: Ton Nga Chang, Inuthai s.n. (PSU). Vietname. KHANH HOA: Nha trang, 11 Apr 1958, Tixier s.n. (PC). Malaysia. PenAnG: without location, Hooker s.n. (G).-PeRAK: Pangkor Island, 
Sukkharak 730 (BKF, GOET).-SABAH: Kalabakan, Wood 1380 (L).-SARAWAK: Mt. Dulit, Aug 1932, Richards s.n., Hep. Sel. Crit. Verdoorn 400 (G, W); Banting, “Beccari 1867” (PC). Singapore. Boekit Timah, Nov 1893, Schiffner s.n., Hep. Sel. Crit. Verdoorn 280 (BR, C, G 2 packets, PC, SING). Indonesia. KALIMANTAN: East Kalimantan, along Bongan river, Meijer B.1197c (L)._JAVA: Bogor ("Buitenzorg"), 1893-1894, Schiffner s.n., Hep. Sel. Crit. Verdoorn 281 (BR, C, G 2 packets, GOET, L 2 packets, PC, S, SING, U).--SuMATRA: West Sumatra, Padang, Pieper s.n. (S), Schild 117 (W). Philippines. BuKIDnON: Impalutao B. F. D. reforestation project, Onraedt 85.P.11043 (BR).-ZZAMBALES: without location, Curran \& Merritt 8192 (G); without location, Curning 1488, 2110 (BM). Federated States of Micronesia. PohnPeI: Mt. Nanlaut, 28 Jun 1949, Glassman s.n. (G). Papua New Guinea. East New Britain: Nakanai Mts., Streimann 40422 (JE).-Milne BAY: near Mita, Micholitz s.n. (G).-MOROBE: Labutali village, Bellamy $178(\mathrm{U})$.

Thysananthus comosus varies in the dentation of leaves and underleaves, which is entire to strongly serrate, and the number of leaf lobule teeth as seen in T. amazonicus.

Thysananthus comosus is closely related to $T$. gottschei, from which it differs mainly by the leaves, which weakly concave when moist (strongly concave in T. gottschei) and underleaves, which are flat obovate and truncate (slightly squarrose, broadly spathulate and rounded in $T$. gottschei).

Thysananthus comosus was described by Lindenberg in 1844 based on two specimens, one from Asia ("Pulo Penang") and one from South America ("Guiana"). Spruce (1884) considered the two specimens different and named the South American plant Lejeunea dissoptera (= T. dissopterus). Fulford (1941), however, considered T. dissopterus as a synonym of $T$. comosus. Gradstein (1994) found that the two specimens are identical except that the material from Pulo Penang is male whereas the plants from Guiana are female; he proposed that $T$. comosus is excluded from the neotropical flora. I have found both male and female plants in the type collection from Pulo Penang and agree with Gradstein to exclude $T$. comosus from the neotropical flora. Reasons for the exclusion were discussed by Gradstein (1.c.).

6. Thysananthus convolutus Lindenb. (Figs. 13-14)

Syn. Hepat. 288. 1845; Stephani (1912: 795); Verdoorn (1933: 230; 1934: 178);

Mizutani (1969: 138; 1977: 135); Gradstein et al. (2002: 72). Jungermannia spathulistipa var. $\Upsilon$ Nees, Enum. Pl. Crypt. Jav.: 38. 1830. Lejeunea (subg. 
Thysanolejeunea) convoluta Lindenb., Trans. \& Proc. Bot. Soc. Edinburgh. 15: 106. 1884. Thysanolejeunea convoluta (Lindenb.) Steph., Hedwigia 29: 142. 1890, nom. inval.-Type: INDONESIA. Java: "Habitat in Javae montosis, v.c. in monte Leback Provinciae Bantam, frequens", Blume s.n. (leclotype, here designated: STR!; isolectotypes: BM!).

Thysananthus subreversus Steph., Sp. Hepat. 4: 791. 1912.-Type: PAPUA NEW GuINEA. Morobe: “Kaiser Wilhelmsland: Sattelberg”, Nyman s.n. (isotype, S!); Icon. Steph. nr. 10218.

Plants dioicous, with projecting growth, turning upwards and becoming ascending to erect, pale green, becoming dark brown to blackish in the older portion in the field, reddish brown in herbarium specimens, up to $2.3 \mathrm{~cm}$ long $\times 1.5-2.2 \mathrm{~mm}$ wide. Stems rather rigid; ventral merogphyte 8-10 cell rows wide; in cross section round-orbicular in shape, 278-297 $\mu \mathrm{m}$ high $\times 230-262 \mu \mathrm{m}$ wide, composed of 37-49 epidermal cells surrounding 107-156 medullary cells in 13-16 layers high, epidermal cells not larger than medullary cells. Leaves strongly imbricate, when dry suberect and strongly convolute, when moist strongly concave, apical parts turn to ventral side, recurved; dorsal lobe asymmetrically ovate, $1-1.3 \times 0.8-0.9(-$ 1.1) $\mathrm{mm}$, apex mucronate-apiculate, dorsal base auriculate, auricle 130-165 × 75-100 $\mu \mathrm{m}$, dorsal margin with 4-6 triangular teeth, the teeth consisting of 3-5 cells, being 2 cells wide at base and ending in a row of 1-2 cells, ventral margin upcurved $2 / 3 \times$ leaf length with 4-5 triangular teeth, the teeth consisting of 3-5 cells, being 2-3 cells wide at base and ending in a row of 1-2 cells; cells elongate-hexagonal with acute ends, vitta cells absent, marginal cells

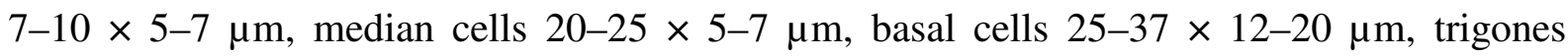
cordate, often coalesced, intermediate thickenings $0-1$ per cell wall; oil bodies $2-4$ per cell. Lobules rectangular, $0.3-0.4 \times 0.1-0.2 \mathrm{~mm}, 1 / 4-1 / 3 \times$ lobe length; appendage on surface of lobule base not developed; keel without appendage; lobule apex oblique, longly continuing into the ventral lobe margin, apex with $1(-2)$ triangular teeth, the first tooth consisting of 3-6 cells, being 2-3 cells wide at base and ending in a row of 1-2 cells, the second tooth of one cell only, often obsolete. Underleaves imbricate, slightly squarrose, broadly spathulate, 0.5$0.6(-10) \times 0.4-0.6 \mathrm{~mm}, 3-4 \times$ stem width, apex truncate to rounded, plane to incurved, with 17-20 triangular teeth, the teeth consisting of 3-4 cells, being 2 cells wide at base and ending in a row of 1-2 cells, bases cuneate, underleaf bases adnate with leaves on one side, on lefthand side for right branches and right-hand side for left branches; cells 12-15 $\times 5-7 \mu \mathrm{m}$. Androecia terminal-intercalary on lateral branches, bracts and bracteoles in 3-4 pairs, bracts hypostatic, $0.9-1 \times 0.7-0.8 \mathrm{~mm}$, apex acute, margins entire; antheridia 2 per bract. Gynoecia 
with one lejeuneoid innovation forming a monochasial pattern; lobe widely ovate, $1.7-1.9 \times$ 9-10 $\mathrm{mm}$, apex apiculate, margin in upper $1 / 3$ with $8-9$ triangular teeth, the teeth consisting of 3-5 cells, being 2-3 cells at base, apex of one cell; lobules broadly ovate, $1 / 2 \times$ lobe length, apex apiculate to obscurely bifid, margins with triangular teeth, the teeth consisting of 5-9 cells, being 2-3 cells at base and ending in a row of 1-2 cells; bracteoles spathulate, 1.3-1.4 $\times$ $0.7-0.8 \mathrm{~mm}$, apex slightly emarginate, $1 / 3 \times$ bracteole length with triangular teeth, the teeth consisting of 3-6 cells, being 2-3 cells wide at base, apex of one cell, margins recurved. Perianths oblong-cylindrical, 2.3-2.5 $\times 0.8-1 \mathrm{~mm}$ long, keels in upper 1/3 with triangular teeth, the teeth consisting of 7-8 cells, being $2-3$ cells at base and ending in a row of 1-2 cells; beak 38-60 $\mu \mathrm{m}$ with 3-4 cells long or obsolete.

Chromosome number. Unknown.

Chemistry. Isolepidozene, bicyclogermacrene and aromadendrene sesquiterpenoids, diterpenoids, and sterols (Gradstein et al., 1985; Sukkharak et al., in press).

Distribution and ecology. Indomalesia; 10-1900 m; on stems of treelets in old cocoa plantations with leguminous shaded trees and old garden sites with regrowth species, bark of living trees and fallen trees in rain forests (primary and secondary forests), and montane forest canopy.

REPRESENTATIVE SPECIMENS. India. ANDAMAN AND NiCOBAR ISLANDS: Andaman Islands, Port Blair, Jul 1890, Man s.n., ex hb. Levier “302” (G, W); ibid., 12 Apr 1891, Man s.n., ex hb. Levier 743 (G); ibid., 13 Jul 1891, Man s.n., ex hb. Levier 775 (G); ibid., 1893, Man s.n., ex hb. Levier 742 (BM, G 5 packets, JE, S 2 packets); Nicobar Islands, Katchal, Kurz 3875 (G). Thailand. NAKhon Si Thammarat: Mt. Khao Luang, Touw 11642 (BKF), Tagawa \& Kitagawa T5045, T5246 (G); Mt. Khao Nan Yai, Sukkharak 208, 348 (BCU); ibid., San Yen, Sukkharak 769, 770, 787, 801, 803, 813 (BKF, GOET). Malaysia. JOHORE: Mt. Ophir, Verdoorn 123, 155, 188 (SING).-PAHANG: Frasers Hill, Schäfer-Verwimp \& Verwimp 18593 (BR); at start of part to Pine Tree Hill, Fraser Hill, Wood 1343 (BM).PenAng: Penang hill, Ridley 549, 553 (SING); Penara Bukit, Ridley 566 (SING).—SABAH: Mt. Kinabalu, camp on path to Paka cave, Wood 1526 (BM, JE); ibid., Eastern Shoulder, ridge below Camp III, Chew \& al. 2011, 2131, 2140 (BM, BM-K); ibid., summit trail, Sukkharak 607, 616, 694 (BKF, GOET), Wallace s.n. (NSW); Tenompok, Holttum 25328 (SING).-SARAwaK: Mt. Dulit, Aug 1932, Richards s.n., Hep. Sel. Crit. Verdoorn 400 (GOET, JE); ibid., Oct 1932, Richards s.n., Hep. Sel. Crit. Verdoorn 397 (BM, G, JE, SING, U, W), Richards 2012 (JE 2 packets), 2052 (BM-K, JE), 2357 (BM); plot 1, Mr. J. A. R. Anderson's sample line at Kabang protected forest, Wood 1421 (BM, JE).-_SELANGOR: 
Semangko Pass, 1904, “Nurdozc” s.n. (SING). Indonesia. JAVA: Cibodas Botanical garden, Gradstein 10204, 10205, 12078 (GOET); ibid., Apr 1894, Schiffner s.n., Hep. Sel. Crit. Verdoorn 282 (BM-K 2 packets, BR, C, G 2 packets, GOET, JE, PC, S, SING, U, W); ibid., Tjibeureum, Apr 1894, Schiffner s.n., Hep. Sel., Crit. Verdoorn 283 (BM-K 2 packets, BR, C, G 2 packets, GOET, JE, PC, S, SING, U, W), Massart 1173, 1200 (BR), Meijer B3681 (G, PC, S, W), B3789 (BM-K, G, PC, S, W), Renner 127, 174, s.n. (JE); Yogyakarta, Gedongan, Kurz s.n. (G).-MALUKU ISLANDS: Ambon, Zippelius s.n. (L).--SuMATRA: Berastagi, garden of former BPM-hotel, Sipman 6897 (U)._-SulawESI: Central Sulawesi, Lake Kalimpaa, Lore Lindu National Park, Gradstein 10324 (GOET); ibid., Mt. Rorekatimbu, Gradstein 12154, 12155, 12158 (GOET), 12156 (GOET, JE); ibid., Bariri, Gradstein 12011 (GOET); Todjamboe, Jul 1929, Kjellberg s.n. (JE).-WeSteRn New GuINEA: West Papua, Arfak Mts., Beccari 1875 (JE). Philippines. Benguet: Baguio, Burgeff 8080 (JE)._Negros oriental: Laka Danao, Sibulan, Edano 13102 (L); Matangwa river, Edano 13027 (L).-CORIENTAL Mindoro: Mt. Halcon, Salgado 88.P.12131 (BR).-QUEZON: Polillo, McGregor s.n. (BM, L), Robinson 9299 (L); Tayabas, Baler s.n. (JE); Digisit beach, Santos 338 (JE); Dimasingay, Santos 360 (JE). Papua New Guinea. Central: Boridi, Carr 13531 (JE)._Eastern HIGHLANDS: near Famin, Kainantu-Okapa road, Streimann 26392 (JE); track to Mt. Michael, Streimann 18803 (JE, LAE); Mt. Gahavisuki nature reserve, Aptroot 18780 (U).-Gulf: Hepataewa, Streimann 33853 (JE).-MilnE BAY: Wapon, Cruttwell 511 (L).-MoroBE: Mt. Kaindi, Streimann \& Bellamy 17690 (BR); Gradstein 3796 (U); Blue point, Gradstein \& Sipman 7883 (G), Gradstein 3778 (U); Oomsis logging area, Streimann 25841, 25879, 25885, 25889 (JE); Herzog Mts., Streimann \& Umba 10993 (JE, LAE); Gumi creek, Streimann 25052, 25137, 25141, 34943 (JE); Slate-Gumi creeks divide, Streimann 13829, 13918 (JE), 13834, 13856 (JE, LAE); upper Watut river, Streimann 33054 (JE); Ekuti divide, BuloloAseki road, Streimann 26106 (JE); Aseki-Menyamya road, Streimann \& Tamba 12156 (JE); Labu swamp, Streimann 25559, 25702 (JE); upper Nawatu Banda, Streimann 24883 (JE).SouTHERn HighLANDS: Lama sawmill, Streimann 26579, 26608, 26660 (JE); Kengaput, Streimann 26848 (JE); Piribu sawmill, Streimann 32515 (JE); Andawe river, Streimann 26530 (JE)._West New Britain: Kapi T. R. P., Kapiura river, Kolema 107 (JE).—WeSt SEPIK: Blackwater refugee camp, Mundua 300 (JE). Solomon Islands. GuADALCANAL: above Tasi-camp along track to Malakuna, van Zanten 68-2435/b (JE).-WESTERN: Kolombangara Island, Braithwaite 4429 (JE). 
Thysananthus convolutus is closely related to $T$. gottschei but differs from the latter by toothed leave and underleaves (entire in T. gottschei) and triangular perianth teeth, 1-2 cells long (laciniate perianth teeth, 2-4 cells long in T. gottschei).

The original material in the Nees Herbarium (STR) contains 5 specimens. Four are Thysananthus convolutus and only one has the mention " $\Upsilon$ ". Since var. " $\mathscr{\Upsilon}$ ' was cited by Lindenberg in the protologue of $T$. convolutus, I have chosen the " $\uparrow$ " material as the lectotype also because it is good material with perianths. No type material of $T$. convolutus was found in the Lindenberg Herbarium (W). Although there is no collector cited, the material is from the same locality as T. spathulistipus, as mentioned in the protologue. I, therefore, assume that the material was collected by Blume.

\section{Key to the varieties of $T$. convolutus}

Keel of leaves without appendage. Underleaf apex plane or incurved. Perianth teeth triangular, $1-2$ cells long 6a. T. convolutus var. convolutus

Keel of leaves on one side of stem with appendage (on the side where leaves and underleaves are free). Underleaf apex strongly recurved. Perianth teeth laciniate, 3-6 cells long 6b. T. convoluts var. laceratus

\section{6a. Thysananthus convolutus var. convolutus}

see under the species

6b. Thysananthus convolutus var. laceratus (Steph.) comb. nov. (Fig. 14)

Thysananthus laceratus Steph., Sp. Hepat. 4: 796. 1912.-Type: MALAYSIA.

Sabah: “Brit. N Borneo, Ulu Moanat Labuh river”, Alau Eltom s.n. (holotype: G!); Icon. Steph. nr. 10190.

The distinguishing characters of this variety are (1) presence of appendage on the keel, on the side where leaves and underleaves are free and opposite to the adnate ones (appendages always curved towards the stems), (2) strongly recurved underleaf apex and (3) obovate, laciniate perianth teeths with 3-6 cells long.

Distribution and ecology. Malaysia (Sabah, Sarawak); without ecological information.

Representative Specimens. Malaysia. Saba: The type. SarawaK: Mt. Dulit, Richards 2357 (BM). 
7. Thysananthus discretus Sukkharak \& Gradst. (Fig. 15)

Cryptog. Bryol. 31: 113-119. 2010.-Type. InDONESIA. West Papua ["Netherlands New Guinea, distr. Hollandia"]: Cycloop Mountains, path IfarOrmoe, alt. 1220 m, 21 Aug 1961, Royen \& Sleumer 5896 (holotype: L!; isotypes: JE!, S!).

Plants dioicous, with projecting growth, turning upwards and becoming ascending to erect, with vigorous shoots, yellowish brown in herbarium specimens, up to $6.5 \mathrm{~cm}$ long $\times 2-$ $3 \mathrm{~mm}$ wide. Stems strongly rigid; ventral merophyte 14-18 cell rows wide; in cross section orbicular-subelliptic in shape, 360-500 $\mu \mathrm{m}$ high $\times 260-445 \mu \mathrm{m}$ wide, composed of 76-80 epidermal cells surrounding 365-381 medullary cells in 16-22 layers high, epidermal cells not larger than medullary cells. Leaves imbricate, when dry suberect and strongly convolute, when moist clasping the stem; dorsal lobes asymmetrically ovate, 1.4-2.3 $\times 1-1.8 \mathrm{~mm}$, apex apiculate, dorsal base auriculate, auricle 100-150 × 125-160 $\mu \mathrm{m}$, dorsal margin entire or with 1-4 triangular teeth, the teeth consisting of 3-4 cells, being 2-3 cells wide at base and ending in a row of 1-2 cells, ventral margin upcurved over most of its length, becoming flat near the apex, entire or with 3-8 triangular teeth, the teeth consisting of 3-5 cells, 2-3 cells wide at base and ending in a row of 1-2 cells; cells elongate-hexagonal with acute ends, vitta cells absent, marginal lobe cells 10-12 × 10-12 $\mu \mathrm{m}$, median cells 32-45 × 5-7 $\mu \mathrm{m}$, basal cells 37$62 \times 17-25 \mu \mathrm{m}$, trigones cordate, often coalesced, intermediate thickenings $0-1$ per cell wall; oil bodies 4-5 per cell, toward leaf base more numerous, up to 8 per cell (Gradstein 3894). Lobules rectangular, $0.6-0.7 \times 0.1-0.2 \mathrm{~mm}, 1 / 4-1 / 3 \times$ lobe length; appendage on surface of lobule base not developed; keels with appendages on one or both sides or not developed, orbicular-oblong, 215-375 $\times 85-150 \mu \mathrm{m}$; lobule apex oblique, longly continuing into the ventral lobe margin, apex with one triangular tooth, the tooth consisting of 5-12 cells, 2-4 cells wide at base and ending in a row of 1-2 cells. Underleaves imbricate, slightly squarrose, broadly oblong to rectangular, $1.2-1.9 \times 0.8-1.4 \mathrm{~mm}, 2-2.5 \times$ stem width, apex broadly rounded to truncate, plane, with 20-25 triangular teeth, the teeth consisting of 3-6 cells, being 2-3 cells wide at base and ending in a row of 1-2 cells, bases auriculate, the auricles 100-275 $\times 200-400 \mu \mathrm{m}$, underleaf bases not adnate with leaves; cells 20-25 × 5-7 $\mu \mathrm{m}$. Androecia terminal-intercalary on lateral branches, bracts and bracteoles in 6-10 pairs, bracts hypostatic, $0.7-0.8 \times 0.5-0.6 \mathrm{~mm}$, apex acute, margins entire; antheridia 2 per bract. Gynoecia with 2 lejeuneoid innovations forming a dichasial pattern; lobe ovate, $2.4-2.7 \times 1.2-1.5 \mathrm{~mm}$, apex 
apiculate, margins in upper $1 / 3$ with triangular teeth, the teeth consisting of $3-5$ cells, being 2-3 cells wide at base and ending in a row of $1-2$ cells; lobules broadly ovate, $2 / 3 \times$ lobe length, apex apiculate, margin with triangular teeth, the teeth consisting 3-5 cells, being 2-3 cells wide at base and ending in a row of 1-2 cells; bracteoles spathulate, 2.3-2.4 × 1.1-1.3 $\mathrm{mm}$, apex emarginate, $1 / 2 \times$ bracteole length with triangular teeth, the teeth consisting of 3-7 cells, being 2-3 cells wide at base and ending in a row of 1-2 cells, margins slightly recurved. Perianths oblong, 2.5-2.6 × 1.1-1.3 mm, keels in upper 1/3 with numerous laciniate teeth, with 3-9 cells long at apex; beak 97-125 $\mu \mathrm{m}$ with 4-7 cells long.

Chromosome number. Unknown.

Chemistry. Sesquiterpeniods, diterpenoids and sterols (Gradstein et al. 1985, under Thysananthus convolutus sample nr. 49).

Additional illustrations. Gradstein et al. (2002, p. 73, Fig. 45, as Thysananthus convolutus).

Distribution and ecology. Endemic to Western Melanesia: Papua (Indonesia), Papua New Guinea and the Solomon Islands; 760-2700 m; on trunks, branches and stems of treelets in rain forests (primary and secondary forests) and montane forests.

Representative Specimens. Indonesia. Western New Guinea: Papua, Cycloop Mts., Royen \& Sleumer 5907 (JE, L); Eipomek-Tal, Hiepko \& Schultze-Motel 2218, 2403 (JE). Papua New Guinea. Central: Boridi, Carr 13531 (JE)._EASTERn Highlands: Daulo Pass, Streimann 17990 (JE); Gahavisuka provincial park, Streimann 18201 (JE).-MoRoBE: Wau, Mt. Kaindi, Gradstein 3778 (GOET), 3856, 3894, 3910 (U), Schuster 67-5786, 675787, 67-5791/c, 67-5792, 67-6282 (JE); Streimann 22497 (JE, LAE), Streimann \& Bellamy 17690 (JE, S, W); Araulu logging area, Streimann 13622 (JE, LAE); Slate-Gumi creeks divide, Streimann 13861 (JE); Spreader divide, Streimann 26036 (JE), Streimann 11846 (LAE), Streimann \& Tamba 11878 (JE, LAE); Aseki-Menyamya road, Streimann \& Tamba 12156 (LAE); Ekuti divide, Bulolo-Aseki road, Streimann 20051, 20103, 26135 (JE); Sattelberg, Clemens 265c (JE, L).-WESTERn Highlands: Jimi-Waghi divide, Streimann 20916 (JE, LAE), 20911 (LAE). Solomon Islands. GuadalCAnal: Mt. Papomanatsen, Braithwaite 4773 (JE).

Thysananthus discretus is a polymorphic species with respect to the dentation of leaves, which varies from edentate to strongly dentate.

Collections of Thysananthus discretus were previously identified as " $T$. appendiculatus", "T. convolutus", "T. gottschei" and "T. sp.". Thysananthus discretus is most 
closely related to widespread Malesian $T$. convolutus and was illustrated as $T$. convolutus by Gradstein et al. (2002: Fig. 45). The illustration clearly shows the free underleaves characteristic of $T$. discretus, which are not connected with the leaves, and the presence of well-developed auricles at the underleaf bases. Thysananthus discretus shares with $T$. convolutus the asymmetric leaves but differs from the latter by (1) leaves when moist clasping the stem (squarrose in T. convolutus), (2) free underleaf bases, with well-developed auricles (underleaf bases adnate with leaves on one side and without auricles in T. convolutus) and (3) strongly rigid stems, with 14-18 cells wide ventral merophytes and medulla 16-22 cell layers high (less rigid stems, with 8-10 cells wide ventral merophytes and 14-17 layers high medulla in $T$. convolutus). Thysananthus discretus may also be confused with $T$. appendiculatus, a species endemic to New Guinea which may possess auricled underleaf bases like $T$. discretus. However, the leaf lobes in T. appendiculatus are symmetric and widely spreading when moist, while in $T$. discretus they are asymmetric and clasping the stem when moist. In addition, leaf and underleaf bases are connected in T. appendiculatus while in $T$. discretus they are never connected. In T. discretus the appendages are present on one or both sides of the stem and are sometimes lacking, while in T. appendiculatus, T. convolutus var. laceratus and T. gottschei var. continuus they are always found on one side of the stem only, on leaves that are free from underleaf bases and opposite to leaves that are connected with underleaf bases. Moreover, the appendages of $T$. convolutus var. laceratus and $T$. gottschei var. continuus are always curved towards the stem while in $T$. discretus and $T$. appendiculatus they are straight or curved.

8. Thysananthus gottschei (Jack \& Steph.) Steph. (Figs. 16-17)

Sp. Hepat. 4: 787. 1912; Verdoorn (1933: 231). Thysanolejeunea gottschei Jack \& Steph., Hedwigia 31: 20. 1892.-Type: PHILIPPINES. Luzon: Wallis s.n. (holotype: G!).

Thysananthus borneensis Steph., Sp. Hepat. 4: 786. 1912.-Type: MALAYSIA. Sarawak: Pearson s.n. (holotype: G!); Icon. Steph. nr. 10168.

Thysananthus reversus Steph., Sp. Hepat. 4: 789. 1912. Thysanolejeunea reversa Steph., Hedwigia 35: 139. 1896.-Type: PHILIPPINES. Zamboanga del Norte: Dapitan, Micholitz 44 (holotype: G!).

Thysananthus rigidus Steph., Sp. Hepat. 4: 790. 1912.—Type: PAPUA NEW GuINEA.

New Ireland [“New Ireland, Nova Hibernia”]: Micholitz s.n. (holotype: G!); Icon. Steph. nr. 10207. 
Plants dioicous, with projecting growth, turning upwards and becoming ascending to erect, reddish brown in herbarium specimens, up to $3.5 \mathrm{~cm}$ long $\times 2.5-3 \mathrm{~mm}$ wide. Stems rather rigid; ventral merogphyte 8-9 cell rows wide; in cross section round-orbicular in shape, 313-320 $\mu \mathrm{m}$ high $\times 225-240 \mu \mathrm{m}$ wide, composed of 45-49 epidermal cells surrounding 129166 medullary cells in 12-16 layers high, epidermal cells not larger than medullary cells. Leaves strongly imbricate, when dry strongly convolute, when moist strongly concave, apical parts turn to ventral side, recurved; dorsal lobe asymmetrically ovate, $1.7-1.9 \times 1.5-1.7 \mathrm{~mm}$, apex mucronate-apiculate, margin entire, dorsal base auriculate, auricle 130-165 × 75-100 $\mu \mathrm{m}$, ventral margin upcurved $2 / 3 \times$ leaf length; cells elongate-hexagonal with acute ends, vitta cells absent, marginal cells 7-9 × 4-7 $\mu \mathrm{m}$, median cells 18-23 × 5-7 $\mu \mathrm{m}$, basal cells $25-29 \times$ 15-20 $\mu \mathrm{m}$, trigones cordate, often coalesced, intermediate thickenings $0-1$ per cell wall; oil bodies unknwon. Lobules rectangular, 0.5-0.6 $\times 0.1-0.2 \mathrm{~mm}, 1 / 3 \times$ lobe length; appendage on surface of lobule base not developed; keel without appendage; lobule apex oblique, longly continuing into the ventral lobe margin, apex with 1(-2) triangular teeth, the first tooth consisting of 3-6 cells, being 2-3 cells wide at base and ending in a row of 1-2(-3) cells, the second tooth of one cell only, often obsolete. Underleaves imbricate, slightly squarrose, broadly oblong-orbicular, $1.5-2.1 \times 0.9-1 \mathrm{~mm}, 3-4 \times$ stem width, apex truncate to rounded, plane to incurved, entire to with 17-20 triangular teeth, the teeth consisting of 3-5 cells, being 2 cells wide at base and ending in a row of 1-2 cells, bases cuneate, underleaf bases adnate with leaves on one side, on left-hand side for right branches and right-hand side for left branches; cells $12-17 \times 7-10 \mu \mathrm{m}$. Androecia terminal-intercalary on lateral branches, bracts and bracteoles in 3-4 pairs, bracts hypostatic, $0.9-1 \times 0.7-0.8 \mathrm{~mm}$, apex acute, margins entire; antheridia 2 per bract. Gynoecia with one lejeuneoid innovation forming a monochasial pattern; lobe widely ovate, 2.3-2.6 × 1.7-1.8 mm, apex acute, margin entire; lobules broadly ovate, $2 / 3 \times$ lobe length, apex apiculate to obscurely bifid; margins with triangular teeth, the teeth consisting of 5-8 cells, being 2-3 cells at base and ending in a row of 1-2 cells; bracteoles spathulate, $2.2-2.4 \times 2-2.3 \mathrm{~mm}$, apex slightly emarginate, $1 / 2 \times$ bracteole length with triangular teeth, the teeth consisting of 3-6 cells, being 2-3 cells wide at base, apex of one cell, margins recurved. Perianths oblong-cylindrical, 2.3-2.5 $\times 0.8-1 \mathrm{~mm}$ long, keels in upper $1 / 3$ with numerous laciniate teeth, with 2-4 cells long at apex; beak 37$50 \mu \mathrm{m}$ with 3-4 cells long or obsolete.

Chromosome number. Unknown.

Chemistry. High amounts of isolepidozene and $\left(\mathrm{M}^{+}\right) 302$, 190(100), 81(95) (Sukkharak et al., in press, under Thysananthus convolutus sample nr. 1-3). 
Distribution and ecology. Indomalesia; 20-2100 m; on road-side trees, bark of living trees and fallen trees in rain forests (primary and secondary forests) and montane forests.

RePresentative Specimens. India. Andaman AND Nicobar Islands: Andaman islands, Port Blair, Jul 1890, Man s.n., ex hb. Levier 79 (G, PC). Thailand. NAKHON SI Thammarat: San Yen, Sukkharak 758, 810 (BKF, GOET). Malaysia. PAHANG: on Genting Highland road, Sukkharak 717, 718, 720 (BKF, GOET).-PENANG: Penang hill, 11 Feb 1949, Allen s.n. (BM-K).-SABAH: Kinabatangan, Bukit Garam, Wood 1432 (BM, BM-K, JE); Tawau, Bombay Burmeh Trading Co. Concession area, Wood 1389 (BM-K); Mt. Kinabalu, summit trail, Sukkharak 616 (BKF, GOET).-Western New GuINEA: West Papua, Soron, Beccari s.n. (JE); Papua, Cycloop Mts., Royen \& Sleumer 5907 (JE). Indonesia. JAVA: West Java, Tjibodas, Nyman s.n. (C 2 packets, G, S, W).--SulaweSI: Central Sulawesi, Lake Kalimpaa, Lore Lindu National Park, Gradstein 10324/2 (GOET).-SUMATRA: Bengkulu, Enggano Islands, "Modigliani”139 (G 2 packets, PC). Philippines. Negros orIEnTAL: Cuernos Mts., May 1908, collector unknown. (BM, G 3 packets, JE, W).-QuEzON: Polillo, Bureau of science no. 10494, McGregor 2-39 (BM, BM-K). Papua New Guinea. CENTRAL: Kuriva logging area, Streimann \& Vinas 14391 (LAE); near Dabamura on Ower's Corner road, Streimann \& Naoni 14900, 14904, 14961 (JE, LAE); Musgrave river road, Itikinumu, Streimann \& Naoni 16690 (JE, LAE); K. B. sawmill, Ehu creek, Streimann \& Naoni 16567 (JE, LAE)._EASTERn Highlands: 25 miles S of Kainantu, Kurokawa 4370, 4371 (JE).GULF: Bema-Kaintiba road, Streimann 33645 (JE, LAE).-MoRoBE: logging area, $7^{\circ} 18^{\prime} \mathrm{S}$ $146^{\circ}$ 45' E, Streimann \& Bellamy 13129 (JE, LAE); Manki Trig., Bulolo-Watut divide, Streimann \& Bellamy 12997 (JE, LAE); Slate-Gumi creeks divide, Streimann 13832, 13861 (JE, LAE); Araulu logging area, Streimann 13639 (JE); upper Watut river, Streimann 23071, 23092, 23101 (LAE); Herzog Mts., Streimann \& Umba 10983 (LAE); Ekuti divide, BuloloAseki road, Streimann 22623 (JE, LAE); Oomsis logging area, Streimann 25836 (LAE, W); Gumi divide, head of Gumi creek, Streimann 25156 (JE, W); Sattelberg, Nyman s.n. (C).West New Britain: South Bunga T. R. P., Bellamy 1357 (JE, LAE, S); Evili river, Streimann 41598, 41608, 41609 (JE); Geleo-Lasilai logging area at Mt. Laliti, Streimann 41055, 41088, 41176, 41209, 41217, 41253/a (JE), 41237 (JE, LAE).-WEST SEPIK: Aitape subdistrict, Darbyshire \& Hoogland 8000 (JE); Blackwater refugee camp, Mundua 314 (JE, LAE).

Thysananthus gottschei was reduced to a synonym of $T$. convolutus and has been called the edentate form of the latter (Grolle \& Piippo, 1984). Phytochemical and molecular results showed that this species should be re-instated (Sukkharak et al., in press; Sukkharak et 
al., submitted). The differences between $T$. gottschei and $T$. convolutus are discussed under the latter species.

\section{Key to the varieties of $T$. gottschei}

Keel of leaves without appendage. Lobule apex longly continuing into the ventral lobe margins. Underleaf apex plane or incurved. 8a. T. gottschei var. gottschei

Keel of leaves on one side of stem with appendage (on the side where leaves and underleaves are free). Lobule apex longly continuing into the ventral and dorsal lobe margins. Underleaf apex strongly recurved. 8b. T. gottschei var. continuus

\section{8a. Thysananthus gottschei var. gottschei}

see under the species

\section{8b. Thysananthus gottschei var. continuus var. nov. (Fig. 17)}

Type: MALAYSIA. Sarawak: "Lunda", Micholitz s.n. (holotype: G!). The name of the new variety refers to the free margin of lobules continuing into the lobe ventral margin over almost the entire length of the ventral margin, and sometimes into the dorsal margin of the lobes.

Carina appendiculata. Lobulus continuus in margine foliorum ventralibus. Amphigastria apice recurvata.

The distinguishing characters of this variety are (1) presence of appendage on the keel, on the side where leaves and underleaves are free and opposite to the adnate ones (always curved towards the stems), (2) free margin of lobules continuing into the lobe ventral margin over almost the entire length of the ventral margin, and sometimes into the dorsal margin of the lobes and (3) strongly recurved underleaf apex.

Distribution and ecology. Malaysia and Philippines; without ecological information.

Representative Specimens. Malaysia. Sarawak: the type. Philippines. Iloilo: Panay, Robinson BS18185 (L).

9. Thysananthus spathulistipus (Reinw. et al.) Lindenb. (Figs. 18-19) 
Syn. Hepat. 287. 1845; Stephani (1912: 799); Verdoorn (1934: 167); Mizutani (1969: 138; 1977: 135); Kitagawa (1973: 271); Thiers \& Gradstein (1989: 71); Gradstein et al. (2002: 80); Wigginton (2004: 282). Jungermannia spathulistipa Reinw. et al., Acta Phys.-Med. Acad. Caes. Leop.-Carol. Nat. Cur. 12: 212. 1824. Jungermannia spathulistipa var. $\alpha, \beta$ Nees, Enum. Pl. Crypt. Jav.: 38. 1830. Lejeunea spathulistipa (Reinw. et al.) Dum., Rec. d'Observ.: 12. 1835, Spruce (1884: 106, in subg. Thysanolejeunea). Frullania spathulistipa (Reinw. et al.) Nees, Naturgesch. Eur. Leberm. 3: 211. 1838. Phragmicoma spathulistipa (Reinw. et al.) Mont., Ann. Sci. Nat., Bot. (2) 16: 128. 1841.-Type: INDONESIA. Java ["Habitat in Javae montosis, v.c. in monte Leback Provinciae Bantam, freqaens"]: Blume s.n. (holotype: STR!; isotypes: G 3 packets!, W!).

Thysananthus triquetrus (Mitt.) Steph., Sp. Hepat. 4: 783. 1912. Lejeunea triquetra Mitt., J. Proc. Linn. Soc., Bot. 7: 167. 1864.-Type: "Bagro river, W. Africa, 1861, Mann s.n.” (holotype: NY!; isotype: BM!), syn. nov.

Thysananthus monoicus Steph., Sp. Hepat. 4: 783. 1912.-Type: MADAGASCAR. Icon. Steph. nr. 10228.

Thysananthus sikkimensis Steph., Sp. Hepat. 4: 798. 1912.-Type: "Himalayas", Levier s.n. (holotype: G!); Icon. Steph. nr. 10212.

Thysanolejeunea amboinensis Schiffn. ex Steph., Sp. Hepat. 4: 799. 1912, nom. inval. Thysananthus hebridensis Steph., Sp. Hepat. 6: 565. 1924.-Type: VAnUATU ["Novae Hebrides"]. Gunn s.n. (lectotype, here designated: G!; isolectotypes: G 2 packets!); Icon. Steph. nr. 10184.

Mastigolejeunea tarkwana Pears., Ann. Crypt. Exot. 4: 63. 1931. (fide Wigginton \& Grolle, 1996).

Thysananthus spathulistipus (Reinw. et al.) Lindenb. var. borneensis Herzog, Mitt. Inst. Allg. Bot. Hamburg: 199. 1931.-Type: INDONESIA. Kalimantan [West Borneo]: Bukit Mulu, 1000 m, 2 XII 1924, H. Winkler 3333 (holotype: JE!), syn. nov.

Thysananthus minor Verd., Recueil Trav. Bot. Néerl. 30: 231. 1933; Gradstein et al. (2002: 74).—Type: InDONESIA. Sumatra: Mt. Brastagi, “Gouv. S. O. K., in silvis pr. cataractas torrentis Petani, infra Brastagi, ca 1350 m”, IX 1930, Verdoorn s.n. (holotype: FH!), syn. nov.

Thysananthus fuscobrunneus Horik., J. Sci. Hiroshima Univ., Ser. B, Div. 2, Bot. 2: 252. 1934.-Type: TAIWAN. Taito: Mt. Chipon, Kiriyama-Miyama, on bark, 31 XII 1932, Y. Horikawa n. 10505a (holotype: HIRO!), syn. nov. 
Thysananthus grossidens Steph. ex Verd., Ann. Bryol., Suppl. 4: 168. 1934, nom. inval.

Plants autoicous, with projecting growth, turning upwards and becoming ascending to erect, green, brownish green to black in the older portion in the field, yellowish brown in herbarium specimens, up to $1.6 \mathrm{~cm}$ long $\times 1.7-2.5 \mathrm{~mm}$ wide. Stems rather rigid; ventral merophyte 7-9 cell rows wide; in cross section round-orbicular in shape, 205-219 mm high $\times$ 163-175 $\mu \mathrm{m}$ wide, composed of 32-46 epidermal cells surrounding 50-95 medullary cells in 14-18 layers high, epidermal cells not larger than medullary cells. Leaves imbricate, when dry suberect and convolute, when moist weakly concave, apical parts plane, not recurved; dorsal lobe symmetrically ovate, 0.8-1.6 × 0.5-1.1 mm, apex acute, dorsal base cordate, dorsal margin entire or with 1-4 triangular teeth, the teeth consisting of 3-6 cells, being 2-3 cells wide at base and ending in a row of 1-2 cells, ventral margin recurved to inrolled $1 / 2 \times$ leaf length, with 3-6 triangular teeth, the teeth consisting of 4-8 cells, being 2-3 cells wide at base, apex of one cell; cells elongate-hexagonal with acute ends, vitta cells absent, marginal

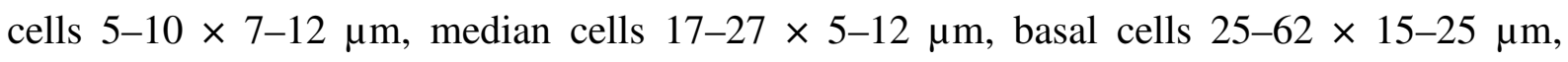
trigones cordate, often coalesced, intermediate thickenings $0-3$ per cell wall; oil bodies 2-4 per cell (Mizutani, 1969: 4-6 oil bodies). Lobules oblong-rectangular, 0.3-0.5 × 0.1-0.2 mm, 1/4-1/3× lobe length; appendage on surface of lobule base not developed; keel without appendage; lobule apex oblique, longly continuing into the ventral lobe margin, apex with 1(2) triangular teeth, the first tooth consisting of 3-4 cells, being 2 cells wide at base and ending in a row of 1-2 cells long, the second tooth of one cell only, often obsolete. Underleaves imbricate, slightly squarrose, broadly obovate-spathulate, $0.3-0.8 \times 0.4-0.7 \mathrm{~mm}, 3-4 \times$ stem width, apex truncate to slightly emarginate, plane, with 8-13 triangular teeth, the teeth consisting of 3-6 cells, being 2-3 cells wide at base and ending in a row of (1-)3-7 cells, bases cuneate, underleaf bases adnate with leaves on one side, on left-hand side for right branches and right-hand side for left branches; cells 7-17 $\times 5-12 \mu \mathrm{m}$. Androecia terminalintercalary on branches, bracts and bracteoles in 2-8 pairs, bracts hypostatic, $0.6-0.8 \times 0.2-$ $0.6 \mathrm{~mm}$, apex acute, margins with 1-2 teeth; antheridia 2 per bract. Gynoecia with 1-2 lejeuneoid innovation forming monochasial pattern or dichasial pattern; lobe ovate, $1.3-1.9 \times$ 0.6-1.1 mm, apex apiculate, margins in upper 1/3 with triangular teeth, the teeth consisting of $3-6$ cells, being $2-3$ cells at base and ending in a row of 1-2 cells; lobules broadly ovate, 1/3$1 / 2 \times$ lobe length, apex apiculate, margins with triangular teeth, the teeth consisting of 5-11 cells, being 2-3 cells at base and ending in a row of 1-2 cells; bracteoles spathulate, 1.2-2.3x $0.5-1 \mathrm{~mm}$, apex emarginate to shortly bifid, $1 / 2 \times$ bracteole length with triangular teeth, the 
teeth consisting of 3-8 cells, being 2-3 cells wide at base and ending in a row of 1-3 cells, margins recurved. Perianths oblong-cylindrical, 1.6-2.4 × 0.6-1.1 mm, keels in upper 1/31/2 with triangular teeth, the teeth consisting 4-15 cells, being 2-4 cells wide at base and ending in a row of 1-2 cells; beak 50-55 $\mu \mathrm{m}$ with 3-4 cells long.

Chromosome number. A haploid number of $n=9$ (Fritsch, 1991).

Chemistry. Isolepidozene (Sukkharak et al., in press), clerodane diterpenoids,

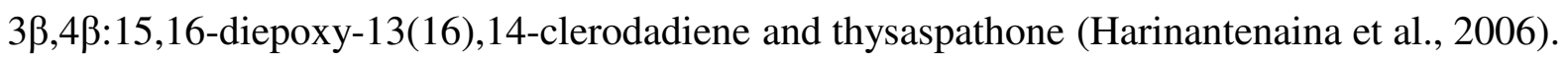

Additional Illustrations. Horikawa (1934, p. 251, Fig. 49 as Thysananthus fuscobrunneus); Vanden Berghen (1950, p. 36, Fig. 1); Thiers \& Gradstein (1989, p. 74, Fig. 28); Gradstein et al. (2002, p. 75, Fig. 47 as T. minor, p. 81, Fig. 51).

Distribution and ecology. Africa, Indochina, Malesia, Australia (Queensland) and the Pacific region; from sea level to $2800 \mathrm{~m}$; on tree trunks, roots, rotten branches and logs along road sides, in the swamp forest, mangrove forest, rain forests (primary and secondary forests) and montane forests.

Representative Specimens. Ivory Coast. TAÏ: Taï National Park, Assi 12739/B (U). Ghana. WESTERN REGION: Ankasa river forest reservation, Jones $1578 b$ (G); ibid., 14 Feb 1971, Jones s.n. (JE). Nigeria. BENIN: Okomu forest reserve, Jones 44, 174B (BM). Cameroon. Southwest Region: Bibundi, Sep 1891, Dusén s.n. (S 4 packets). Gabon. without location, 24 Jun 1927, Testu s.n. (PC, S). Zaire. KIVU: Irangi forest station (Bryotrop Expedition loc. 120), Pócs 6601 (G, U), 6735 (G). Seychelles. BEAu Vallon: forest above Le Niol, Norkett 16600 (BM).--PORT GLAUd: Morne Seychellois National Park, Onraedt 74.S.258 (JE), Norkett 16429, 16512, 16539, 16687 (JE), Pócs 00105, 00105/B, 9335/B (G); Congo Rouge Relict forest, Norkett 17148 (BM, JE); La Misere road, Norkett 16512, s.n. (BM); summit of Morne Blanc, Norkett 18603 (BM); Sans Souci road, Norkett 16687 (BM); old Capucin Mission, Trois Frêres road, Norkett 16429 (BM, JE); Val Riche, Pócs 9333/L (G 4 packets, PC); NE escarpment of Trois Frêres, Pócs 9315/W (GOET); Morne Seychellois national park, Copolia summit, Pócs 9335/B (G 2 packets); ibid., in a depression of Mare aux Cochons valley, Pócs s.n. (G 2 packets).-SilhoueTtE IsLAND: near Pota Eau ridge, Norkett 17741 (BM), without location, Alexejev 13 (JE).--SOUTH EAST ISLAND: Ridge of Brulle, Norkett 17933 (BM). Madagascar. AlaOtra-MANGORO: forest in Analamazoata, Camboué s.n. (PC).-ANTSIRANANA: Diego-Suarez, Radama, Aptroot \& Hensen $13198 B$ (U); Tamatave, Andasibe, Aptroot \& Hensen 13433 (U).- - Atsimo-ANTSIRANANA: Renana stream, Humbert 3451 (PC). Réunion. SAINT-BENOIT: between Grand Etang and road, “ $M$ ” 17.855, 
Onraedt 73.R.1387 (BR 2 packages). Mauritius. Plaines WILHEMS: Le Patrin, "Guého” 48 (PC); without location, “Bélauger" s.n. (BM).

India. ANDAMAN AND NICOBAR ISLANDS: Andaman Islands, Port Blair, 14 Nov 1890, Man s.n., ex hb. Levier 773 (G); ibid., 1893, Man s.n., ex hb. Levier 741 (G); ibid., ex hb. Levier 774 (G 2 packets, JE, S 2 packets); ibid., Oct 1898, Man s.n., ex hb. Levier 1715 (BM, G 2 packets, PC); Port Monate, Kurz s.n. (BM 3 packets, PC); without location, Kurz s.n. (BM, G), 1622, 1631 (G). Sri Lanka. CEnTRAL: Adam's peak, Onraedt 87.L.8801 (BR).SOUTHERN: Beraliya forest reserve, Onraedt 76.L.3284 (BR, JE); Hiniduma, Onraedt 76.L.3508 (JE), 77.L.4304, 81.L.9291, 81.L.9292, 81.L9370 (BR), 76.L.3454, 76.L.3508 (BR, JE), 76.L.3684 (PC); Kammeliya forest reserve, Onraedt 77.L.4257 (BR). China. HaInAN: Kwangtung, Chen Pang-Chieh \& al. 382, 435c, 633 (L). Thailand. Chanthaburi: Khao SaBab, Sapanuchart s.n. (BCU).-C CHIANG MAI: Mt. Inthanon, Touw 9613 (BKF)._LoEI: Mt. Phu Luang, Thaithong 201 (BCU), Touw 10530 (BKF); ibid., north ridge, Tagawa \& Kitagawa T1366, T1377 (G); ibid., eastern slope, Tagawa \& Kitagawa T1876 (G); ibid., north-eastern ridge, Tagawa \& Kitagawa T1686, T1873 (G); Phu Kradung, Touw 10959 (BKF), Tagawa \& Kitagawa T1019 (G); ibid., Pen-Pop waterfall, Thaithong 972 (BCU).NAKHON Ratchasima: Khao Khiao, Tixier 319 (PC).—NAKhOn Si Thammarat: Mt. Khao Luang, Smitinand 1027 (BCU, BKF), Touw 10667, 11354, 11360, 11768, 11875, 11883, 12015, 12023 (BKF), 11686, 11738 (BKF, BR), Tagawa \& Kitagawa T5067, T5072, T5154 (G); Mt. Khao Nan Yai, Sukkharak 50, 130, 170, 180, 183, 189 (BCU); ibid., San Yen, Sukkharak 739, 751, 752, 762, 766, 768, 784, 788, 793 (BKF, GOET).-PHANG NGA: on the way to Roe-Si-Sawan cave, Boonkerd 14 (BCU); Sri Phang Nga National Park, Chantanaorrapint 2089, 2096, 2099, 2100 (PSU).-PRACHINBURI: Khao Yai National Park, Touw 12104, 12360 (BKF), 12103 (BKF, BR).--RANONG: La-Oon mangrove forest, Thaithong 981 (BCU); hot spring, Tixier 3895 (PC).-SATUN: Taritao Island, Chantanaorrapint s.n. (PSU).--TRAT: Chang Klau, Hui Range, Smitinand 1453 (BCU, BKF); Koh Kood, Sukkharak s.n. (BKF, GOET); Koh Chang, 10 Feb 1900, Schmidt s.n. (C).TrAng: Mt. Khao Chong, Tagawa \& Kitagawa T6877, T6965, T6970, T6974 (G). Cambodia. Tonle Sap, Tixier 3864 (PC). Cambodia. KАMPOT: Mt. Bokor, Tixier 2669, 3006, 3027, 3196, 3225, 3313, 3603, 3710 (PC); Tonle Sap, Tixier 3835 (PC). Vietnam. LAM ĐồnG: Da Lat, 21 Sep 1957, Tixier s.n. (PC). Malaysia. JOHORE: Mt. Ophir, Verdoorn 58, 66, 100, 135, 170 (SING).-KADAH: Gg. Raya, Haniff \& Nur 7120 (SING); Kedah peak, Tixier 6058 (PC), Holttum 14889 (SING).-MALACCA: Gg. Tunduk, Ridley 701 (SING).-NEGRI SEMBILAN: Bukit Putus, Ridley 751 (SING).-PAHANG: Cameron Highland, trail to Gunung Jasar, Gradstein 10400/1, 10400/2, 10404/1, 10404/2 (GOET); 2.5 miles on Genting Highland road, 
Een s.n. (JE, S); Fraser's Hill, Tixier 4753 (PC); ibid., 21 May 1997, Schäfer-Verwimp \& Verwimp s.n. (G); the road to Genting Hightland, Sukkharak 716, 719, 722 (BKF, GOET).Penang: Penang hill, Allen 754 (L), Ridley 525 (SING).-_PeraK: Taiping, Ilkiu-Borges \& al. 2981 (GOET); Gunong Batu Putih, Wray s.n. (BM, G, SING, W); Buyong Malacca, Ridley 723 (SING).-SABAH: Mt. Kinabalu, Kamborangah, Holttum s.n. (SING); Silau-Silau trail, Sukkharak 562 (BCU), Sukkharak 549, 550, 593 (BKF, GOET).-SARAWAK: Mt. Dulit, Aug 1932, Richards s.n., Hep. Sel. Crit. Verdoorn 400 (BR, C, GOET, PC, SING, U); ibid., 1932, Richards 2276, Hep. Sel. Crit. Verdoorn 450 (BR, C, G, GOET, JE, PC, S, SING, U, W); ibid., Oct 1932, Richards s.n., Hep. Sel. Crit. Verdoorn 397 (C, GOET); ibid., Nov 1932, Richards s.n., Hep. Sel. Crit. Verdoorn 398 (C), Richards 1208, 2339 (SING), Synge 2083 (BM); ibid., Dulit trail, Richards 1182 (JE); Sibu, Loba Kabang protected forest, Wood 1420 (BM-K, L); Banting, Beccari 1867 (U). Singapore. Chua Chu Kang, Ridley 441 (SING 2 packets); Gardens, Ridley 600 (SING). Brunei. TEMBURONG: $1.5 \mathrm{~km}$ NE of Kampong Semabat, Seah 534 (SING). Indonesia. JAVA: East Java, Tretes, on N-slope of Mt. Ardjuno, Sipman 6992 (U); Dorowatti, May 1929, Clason s.n. (L); West Java, Mt. Salak, Fleischer 76 (S); Mt. Gede, Artja, Apr 1894, Schiffner s.n., Hep. Sel. Crit. Verdoorn 289 (BM, BR, C, G 2 packets, GOET, JE, PC, S, SING, W); ibid., Perbawati, Jul 1930, Verdoorn s.n., Hep. Sel. Crit. Verdoorn 290 (BM 2 packets, BR, C, G 2 packets, JE, PC, S, SING, U 2 packets,W); Cibodas, Apr 1894, Schiffner s.n., Hep. Sel. Crit. Verdoorn 291 (BM 2 packets, BR, C, G 2 packets, GOET, JE, PC, S, SING, U, W); ibid., Feb 1931, Renner s.n. (JE 2 packets), Fleischer s.n. (C); Tjiburrum, Nov 1927, Burgeff 8103 (JE, S), “Noeste” 308 (JE); Mt. Pangerango, Kurz s.n. (BM 2 packets).-KALIMANTAN: East Kalimantan, peak of Balikpapan, Meijer B1332c, B1416 (S) ); Nunukan, Meijer B4921 (BM-K).-LESSER SUNDA ISLANDS: Bali, Bali Handara country club, Schäfer-Verwimp \& Verwimp 20790 (GOET).—SULAwESI: Central Sulawesi, Lore Lindu National Park, Mt. Nokilalaki, Gradstein \& Ariyanti 11000, 11041, 11052 (GOET), Central Sulawesi, Nov 1888, Warburg s.n. (JE).—SUMATRA: BangkaBelitung, Balai, 1869-1870, Teysmann s.n., Hep. Sel. Crit. Verdoorn 399 (BR, C, G, GOET, JE, PC, S, SING, U, W); Mt. Menoembing, Teysmann 30 (GOET), 30/A, 30/B (L); North Sumatra, Bandar Baroe, Staal S-249 (L); West Sumatra, Singalang, Jul 1894, Schiffner s.n., Hep. Sel. Crit. Verdoorn 288 (BR, C, PC, S, SING, U); Lubuk Sikaping, 1931, Renner s.n. (JE, S); Padang, Schild 107 (JE, W); Singalang, Schiffner \& Indicum 2924, 4009 (U).Western New Guinea: Papua, Cycloop Mts., Royen \& Sleumer 6256 (BR, JE, U); Kadubaka, Swart valley, Bergman H.50, H.51 (S); West Papua, Vogelkop Peninsula, Royen \& Sleumer 7966 (BR, JE, U); Bian Katem, van Zanten 229 (U). Philippines. AGUSAN DEL NORTE: Butuan, Weber 1343 (BM-K); Mt. Urdaneta, Oct 1912, collector unknown. (BM, G, 
PC, U, W).-Benguet: Baguio, Feb 1928, Burgeff s.n. (S).-ORiental Mindoro: Mt. Malasimbo, Bartlett 13865 (JE); Mt. Banahao, Alvarez 0-77512 (JE).-QuEZON: Botanical Garden of University of the Philippines Los Banõs, Onraedt 85.P.11342 (BR).- SAMAR: Silanga, Merrill 9005 (BM). Papua New Guinea. CENTRAL: Varirata National Park, Sloover 42.564 (BR); Boridi, Carr 13537 (JE), 13528 (BM, L 2 packets); near Dabamura on Owers Corner road, Streimann \& Naoni 14879, 14950 (JE, LAE); Kuriva logging area, Streimann \& Vinas 14421 (LAE), 14448 (JE, LAE); Bereina-Angabanga river road, Streimann \& Naoni 16303 (JE, LAE); K. B. sawmill, Ehu creek, Streimann \& Naoni 16499, 16633 (LAE), 16668 (JE, LAE); road to Musgrave river, Streimann \& Naoni 15239, 15953 (JE, LAE).-EAST SEPIK: Ambunti subdistrict, along Yapa, Hoogland \& Craven 10121, 10738 (JE).-MorobE: Wau, Mt. Kaindi, Kunai Creek, Gradstein 3964 (G 2 packets, U 3 pakcets), 3965 (U); Kaisenik logging area, Shea 6404 (JE); Mt. Missim track, Streimann 22911 (GOET), 22919 (JE, LAE); Molukkerne, Nyman s.n. (S); Yinimba, Streimann 19032, 19095 (JE, W); Windowi village, Streimann \& Kumei 22648 (JE, LAE); logging area, $7^{\circ} \mathrm{S} 146^{\circ} 45^{\prime} \mathrm{E}$, Streimann \& Bellamy 13311 (JE, LAE); Slate-Gumi creeks divide, Streimann 13831 (JE, LAE), 13973 (LAE); Gumi divide, Streimann 22743 (LAE), 22733 (JE, LAE); Aiuwa-Bakia track, Streimann \& Tamba 12274 (LAE), 12399 (JE, LAE); Herzog Mts., Streimann \& Umba 10838, 10854, 10869, 10916, 10964, 11012 (JE, LAE); Araulu logging area, Streimann 13565 (JE, LAE), 13553, 13571 (LAE); upper Watut river, Streimann 23100 (BR, JE, LAE); WauSalamaua track, Streimann 25392 (JE); upper Nawata Banda, Streimann 19519, 24868, 24872, 33962 (JE); Bulolo-Watut divide, Streimann 17480, 24968, 24995 (JE); ibid., Manki Trig, Streimann \& Bellamy 13066 (LAE); Angabena ridge, Aseki-Bulolo road, Streimann 25918 (JE); Gumi divide, head of Gumi creek, Streimann 25136, 25066 (JE); Heads Hump, Streimann 17374, 17402 (JE); Kaisenik logging area, Shea 6404 (JE); Oomsis logging area, Streimann 25839 (JE); Mt. Kaindi, Blue Point, Gradstein 3793 (G, U 3 packets); Pouyu village, Streimann \& Tamba 12662 (LAE); Nauti logging area, Streimann \& Kairo 17299 (LAE).-_New IRELAnd: Mussau Island, Bismarck Archipelago, Køie \& Olsen 2070 (C, JE).--Southern Highlands: Tari-komo road, Streimann 32712 (BR, JE, LAE, W); Piribu sawmill, Streimann 32473 (JE); Lama sawmill, Streimann 26605, 26611 (JE).-WEST NEW BRITAIN: slopes of Mt. Ulawun, Streimann 41386 (JE); Nakanai Mts., Streimann 40478 (JE); ibid., Geleo-Lasilai logging area at Mt. Laliti, Streimann 41086 (JE).—WEST PROVINCE: Star Mts, Sibil-valley, van Zanten 559 (L); ibid., Antares Mts, van Zanten 559/B (L).-WeSTERN HIGHLANDS: Baiyer river-Ruti road, Jimi valley, Streimann 22061 (JE, LAE), 22242 (BR, JE, LAE).-WEST SEPIK: Antingin, Eliptamin, Macrosimnok 4 (JE). 
Australia. QueEnSland: Cardwell, Stoney creek, 21 May 1982, Stone s.n. (U); El Arish, 11 Jul 1982, Stone s.n. (U); Cook district, Bellenden Ker National Park, Thiers \& Halling 2397 (U); Main coast range, Daintree river National Park, Pócs \& Streimann 9987/L (GOET); Cape Tribulation area, Gap creek, Pócs \& Streimann 99105/K (GOET); Boonjie state forest, Streimann 27553 (JE); Cooroo logging area, Streimann 29943, 29970 (JE); Dunn creek, Kirrima road, Streimann 31234, 31241, 31255, 31257 (JE); Cardwell range, Streimann 28591 (JE); Koombooloomba dam road, Streimann 28910, 28923 (JE); Culpha creek catchment, Streimann 28982 (JE); Mossman Gorge, 26 May 1975, Stone s.n. (JE); Main coast range, Streimann \& Gray 27172 (JE); Walter Hill range, Streimann 30477 (JE); Mt. Lewis NW of Cairns, Hicks 11576 (U); ibid., 29 Jun 1982, Stone s.n. (U); ibid., 29 Jun 1984, Stone s.n. (U); The Boulders rain forest reserve along Babinda Creek, Pócs \& Streimann 9983/L (G); North Kennedy, Renner 1679; ibid., Babinda creek, Renner 1842c; ibid., Little Birthday creek, 29 Jun 2005, Brown 2005/86 \& Renner s.n. (NSW).

New Caledonia. NorTH: Diahot, l'Ignambi, Hürlimann 2858a (G, GOET, PC), 2858 (U); Mt. Panie, Morat 6909 (PC).—South: 1'Est, Hürlimann 2215 (G, GOET, PC, U); Mé Amméri, Guillaumin \& Baumann 9097 (GOET); south of Kouanémoa Mts., Hürlimann 2334 (G, GOET, PC, U); Rivière Bleue, Guillaumin \& Baumann 10894 (GOET, PC, U); Mt. ouénarou, Guillaumin \& Baumann 11875A (GOET); Mois de Mai, Yaté, Baumann 14028 (G, GOET, PC); Ni, Hürlimann 2709 (G, PC, U); Tao, Jan 1910, Franc s.n. (G, PC, S, W); Yaté, Kee 42654 (PC). Fiji. NAITASIRI: Mt. Tomanivi, Hürlimann T1096e (GOET). Samoa. UPOLU: montane forest west of Tiavi, Schutze-Motel 3601 (JE).

Reported from Philippines (Negros Oriental) by Mizutani (1977). Additional specimens reported from China, Hainan, Tianchi Forest Farm, Lin 3843 (IBSC); Yajia Forest Farm, 1974, survey team 3344 (IBSC) (J. Wang, pers. comm.).

Thysananthus spathulistipus is a rather polymorphic species with respect to the dentation of leaves, which varies from edentate to strongly dentate as seen in $T$. comosus, $T$. discretus and T. mollis. In montane forests of Sulawesi, Gradstein (pers. comm.) noted that phenotypes from below $2000 \mathrm{~m}$ were green in color and rather small whereas those from the upper montane cloud forest at 2300-2600 m were brown-green when fresh and more robust.

Thysananthus spathulistipus is closely related to T. appendiculatus. Differences are discussed under the latter species.

The original material of the species in the Nees herbarium in STR contains 10 specimens, mostly from "Bantam" but only one annotated as originating from "Leback". The latter specimen is considered the holotype. 


\section{Thysananthus series Anguiformes ser. nov.}

Cellulae epidermales dorsales dilatatae. Amphigastria adnata. Bracteae et bracteolae femininae integra.

Type species: Thysananthus anguiformis (Hook. f. \& Taylor) Steph.

Dorsal epidermis cells of stem larger than inner cells. Underleaf bases adnate with leaves on one side. Margins of female bracts and bracteoles entire.

Distribution: New Zealand and New Caledonia.

10. Thysananthus anguiformis (Hook. f. \& Taylor) Steph. (Fig. 20)

Sp. Hepat. 4: 800. 1912. Jungermannia anguiformis Hook. f. \& Taylor in Hooker, London J. Bot. 3: 567. 1844. Mastigolejeunea anguiformis (Hooker f. \& Taylor) B. Thiers \& Gradst., Mem. New York Bot. Gard. 52: 75. 1989.—Type. NEw ZEALAND. Colenso s.n. (lectotype, designated by B. Thiers \& Gradstein, 1989: FH!; isolectotype: NY!; paralectotypes: BM-Colenso 226, 1222, 2121!).

Plants dioicous, with projecting growth, turning upwards and becoming ascending to erect, yellowish to reddish brown in herbarium specimens, up to $3 \mathrm{~cm}$ long $\times 1-1.6 \mathrm{~mm}$ wide. Stems rather rigid; ventral merophyte 6-7(-9) cell rows wide; in cross section orbicular in shape, 123-211 $\mu \mathrm{m}$ high $\times$ 86-217 $\mu \mathrm{m}$ wide, composed of 15-27 epidermal cells surrounding 16-62 medullary cells in 6-11 layers high, dorsal epidermal cells larger and somewhat thinner-walled than medulla and ventral epidermal cells. Leaves imbricate, when dry suberect and slightly convolute, when moist concave, apical parts turn to ventral side, recurved; dorsal lobes asymmetric ovate, $0.7-1.2 \times 0.5-1 \mathrm{~mm}$, apex acute, margin entire, dorsal base cordate, ventral margin plane; cells elongate-hexagonal with acute ends, vitta cells absent, marginal cells 7.5-10 × 7.5-12.5 $\mu \mathrm{m}$, median cells $20-30 \times 7.5-12.5 \mu \mathrm{m}$, basal cells $25-45 \times 12.5-$ $17.5 \mu \mathrm{m}$, trigones cordate, often coalesced, intermediate thickenings $0-1$ per cell wall; oil bodies unknown. Lobules rectangular, $0.3-0.4 \times 0.2-0.3 \mathrm{~mm}, \pm 1 / 2 \times$ lobe length, appendage on surface of lobule base not developed; keels sometimes with appendages on one side where leaves and underleaves are free and opposite to adnate ones; lobule apex truncate-rotundus, ending abruptly in a short point of ventral lobe margin, free margin slightly upcurved, apex with one triangular or elongate tooth, the tooth consisting of 5-9 cells, being 2-3 cells wide at base and ending in a row of 1-5 cells. Underleaves imbricate, slightly squarrose, broadly 
obovate, $0.3-0.5 \times 0.5-0.7 \mathrm{~mm}, 4 \times$ stem width, apex broadly rounded to truncate, margins entire, bases cuneate, underleaf bases adnate with leaves on one side, on left-hand side for right branches and right-hand side for left branches; cells 20-22.5 × 7.5-10 $\mu \mathrm{m}$. Androecia terminal-intercalary on lateral branches, bracts and bracteoles in 3-6 pairs, bracts epistatic, ovate, $0.7-0.8 \times 0.4-0.5 \mathrm{~mm}$, apex acute, margins entire; antheridia 2 per bract. Gynoecia with 2 lejeuneoid innovation forming a dichasial pattern; lobe ovate, $0.9-1.3 \times 0.5-0.8 \mathrm{~mm}$, apex apiculate, margin entire; lobules broadly ovate, $1 / 2 \times$ lobe length, apex apiculate, margin entire; bracteoles obovate, $0.7-0.9 \times 0.5-0.8 \mathrm{~mm}$, margins entire, slightly recurved. Perianths oblong, $1.2-1.3 \times 0.7-0.8 \mathrm{~mm}$, keel in upper $1 / 4$ with triangular teeth, the teeth consisting of 3-6 cells, being 2 cells wide at base and one long at apex; beak 82-200 $\mu \mathrm{m}$ with $6-11$ cells long.

Chromosome number. Unknown.

Chemistry. Unknown.

Distribution and ecology. Endemic to New Zealand; 50-150 m; on tree trunks, rotten logs, on branches in dense bush near sea shore, wet forest dominated by treeferns.

Representative Specimens. New Zealand. Auckland: Waitakeke range near Auckland, 3 Aug 1983, Braggins s.n. (GOET, U); Great Barrier Island, Kirk 218 (G); Coromandel state forest, Schäfer-Verwimp \& Verwimp 13731 (GOET)._BAY OF PLENTY: Mamaku forest, Een NZ063, NZ064 (S); Rotorua, Allison s.n. (S); near Rotorua, 17 May 1929, "Kwallison" s.n. (JE); 3 miles west of Rotorua, 15 Apr 1966, Wade s.n. (JE).NORTHLAND: Waipoua Kauri forest, Hatcher 436, 475/b (JE), Schäfer-Verwimp \& Verwimp 13662 (U); Bay of Islands, Kirk 76 (G).-_Southland: Martin's bay, Hatcher 963/c (JE); North of Mc Kerrow river, Hatcher 808 (JE).-WELLINGTON: Akatarawa forest park, Mues $80 a, 80 b$ (U).-WESt COAST: Mt. Stormy trial, Frahm 20-10 (GOET); Matheson lake, Mues 80d (U); Westland national park, Schäfer-Verwimp \& Verwimp 14058 (GOET 2 packets).

Thysananthus anguiformis was treated as Mastigolejeunea anguiformis by Thiers \& Gradstein (1989). This species, together with T. pancheri, was long placed in Mastigolejeunea because of its entire female involucres and enlarged dorsal epidermis cells. Molecular work, however, has confirmed that $T$. anguiformis and T. pancheri are members of Thysananthus (Wilson et al., 2007a; Sukkharak et al, submitted). The robust sister-group relationship of ser. Thysanathus and ser. Anguiformes is supported by the presence of adnate underleaves (Sukkharak et al, submitted). 
Thysananthus anguiformis characterized by truncate-rotundus apex lobules, ending abruptly in a short point of ventral lobe margin. This species varies in shape of lobule teeth, which are elongate, 2-5 cells long to triangular, 1-2 cells long.

11. Thysananthus pancheri (Steph.) Hürl. (Fig. 21)

Bauhinia 9: 167. 1989. Mastigolejeunea pancheri Steph., Sp. Hepat. 4: 771. 1912.-Type: New CAledonia. Pancher 591 (isotypes: PC 3 packets!); Icon. Steph. n. 7448.

Plants dioicous, with projecting growth, turning upwards and becoming ascending to erect, yellowish brown to reddish brown in herbarium specimens, up to $1.8 \mathrm{~cm}$ long $\times 1.9-2.2$ mm wide. Stems rather rigid; ventral merophyte 7-9 cell rows wide; in cross section orbicular-subelliptic in shape, 159-230 $\mu \mathrm{m}$ high $\times 159-176 \mu \mathrm{m}$ wide, composed of 25-33 epidermal cells surrounding 42-47 medullary cells in 9-10 layers high, dorsal epidermal cells larger and somewhat thinner-walled than medulla and ventral epidermal cells. Leaves imbricate, when dry suberect and convolute, when moist strongly concave, apical parts turn to ventral side, recurved; dorsal lobes asymmetric broadly ovate, 1.1-1.6 $\times 0.9-1.2 \mathrm{~mm}$, apex acute, margin entire, dorsal base auriculate, auricle 50-82 × 125-75 $\mu \mathrm{m}$; cells elongatehexagonal with acute ends, vitta cells absent, marginal cells 7.5-12.5 × 10-15 $\mu \mathrm{m}$, median cells $22.5-27.5 \times 12.5-20 \mu \mathrm{m}$, basal cells $25-45 \times 17.5-25 \mu \mathrm{m}$, trigones cordate, often coalesced, intermediate thickenings $0-1$ per cell wall; oil bodies unknown. Lobules rectangular, $0.6-0.7 \times 0.3-0.4 \mathrm{~mm}, \pm 1 / 2 \times$ lobe length; appendage on surface of lobule base not developed; keel without appendage; lobule apex oblique, longly continuing into the ventral lobe margin, apex with one triangular tooth, the tooth consisting of 6-12 cells, being 2-4 cells wide at base and ending in a row of 1-3 cells. Underleaves imbricate, slightly squarrose, broadly obovate, $0.5-0.8 \times 0.6-1.2 \mathrm{~mm}, 2-2.5 \times$ stem width, apex broadly rounded to truncate, margins entire, bases cuneate, underleaf bases adnate with leaves on one side, on left-hand side for right branches and right-hand side for left branches; cells 22.5-17.5 × 7.5$10 \mu \mathrm{m}$. Androecia terminal-intercalary on lateral branches, bracts and bracteoles in 3-8 pairs, bracts hypostatic and epistatic, $0.5-0.8 \times 0.4-0.6 \mathrm{~mm}$, apex acute, margins entire; antheridia 2 per bract. Gynoecia with one lejeuneoid innovation forming a monochasial perttern; lobe ovate, $1.1-1.4 \times 0.5-0.7 \mathrm{~mm}$, apex apiculate, margin entire; lobules broadly ovate, $1 / 2 \times$ lobe length, apex apiculate, margin entire; bracteoles obovate, $1-1.2 \times 0.5-0.7 \mathrm{~mm}$, apex truncate, margins entire, slightly recurved. Perianths oblong, $1.3-1.4 \times 0.5-0.8 \mathrm{~mm}$, keels in upper $1 / 3$ 
with numerous laciniate teeth, with 2-6 cells long at apex; beak 57.5-112.5 $\mu \mathrm{m}$ with $6-8$ cells long.

Chromosome number. Unknown.

Chemistry. Unknown.

Distribution and ecology. Endemic to New Caledonia; 40-1100 m; on bark in Nothofagus balansae (Baill.) Steenis, Spermolepis sp., Leucopogon sp., Canariellum sp. and Exocarpos phyllanthoides Endl. forests.

Representative Specimens. New Caledonia. North: Oua Tilou, BaumannBodenheim 12421a (G, GOET); Voh, Guillaumin \& Baumann 12165 (GOET); Mt. Ignambi, Hürlimann 2864 (GOET); Nehoue, Kee 36864 (PC).—SoutH: Mt. Koghis, Franc s.n. (JE); Rivière Bleue, Hürlimann $2665 a$ (G, GOET), 10864 (GOET); Rivière Blanche, BaumannBodenheim 13949 (G, GOET); Boulari valley, Hürlimann 2304a (G), 2303 (G, GOET, PC, U); ramp north-western of Mt. Quitchambo, Hürlimann 9343 (G, GOET); Mt. Sources, Hürlimann 2206 (G, PC, U), Kee 44013 (PC); Quinné valley of Mt. Dzumac, Hürlimann 2624 (G, GOET, PC, U), 2463 (GOET, PC, U); north-western of Mt. Natégou, Hürlimann 2279, 2292 (G), 2289a (GOET, PC, U); Kouébuni, Hürlimann 2249, 2255, 2256 (G), 2252 (G, U); Koéalagoguamba, Hürlimann 2584a (G); "southern woodland", Guillaumin \& Baumann 11703, 11704, 11713a (GOET); Rivière Pirogues, Guillaumin \& Baumann 11703, 11704 (G); Rivière Voh, Guillaumin \& Baumann 12165 (G, GOET); Yaté, Kee 42653 (PC).

Thysananthus pancheri varies in plant sizes, which are $48-57 \mathrm{~mm}$ to $70-75 \mathrm{~mm}$. This species may be confused with $T$. gottschei but the latter species has epidermal cells not larger than medullary cells, spathulate underleaves and only one lejeuneoid innovation.

Incongruence between plastid and ITS data in one sample of Thysananthus pancheri led to the first report of a hybrid in Lejeuneaceae, and the first one in liverworts inferred from phylogenetic data (Sukkharak et al., submitted; Figs. 5-6). In the cpDNA phylogeny (Fig. 5) T. pancheri sample 2 is sister to T. pancheri sample 1, and both samples are placed in a wellsupported clade with $T$. anguiformis in the cp DNA phylogeny. In contrast, in the nuclear ITS tree (Fig. 6) T. pancheri sample 2 is sister to the T. appendiculatus-T. discretus clade with significant support. The plastid phylogeny concurs with the current species circumscription, whereas the ITS phylogeny is probably the deviating one as T. pancheri is morphologically well separated from T. appendiculatus and T. discretus. Based on the single dated phylogeny of Lejeuneaceae (Wilson et al., 2007b) together with the larger plant size, these considerations provide first evidence that $T$. pancheri sample 2 is of hybrid origin. Given the maternal 
inheritance of plastids in bryophytes, $T$. pancheri should be considered the maternal parent of T. pancheri sample 2, whereas either $T$. appendiculatus or $T$. discretus is probably the paternal parent of the hybrid. However, inference from a more detailed dated phylogeny of Ptychanthoideae may confirm the putative young age of the hybridization event. Further analyses including chromosome counts may determine a possible polyploidy of $T$. pancheri sample 2 .

\section{Thysananthus section Dendrolejeunea (Spruce) comb. nov.}

Lejeunea subg. Dendrolejeunea Spruce, Trans. Proc. Bot. Soc. Edinburgh 15: 110. 1884. Dendrolejeunea (Spruce) Lacout., Rev. Bryol. 35: 104. 1908. Thysananthus sect. Vittatae Verd., Ann. Bryol. Suppl. 4: 182. 1934.-Type: Dendrolejeunea fruticosa (Lindenb. \& Gottsche) Lacout. Taxon named for its dendroid habit.

Type species: Thysananthus fruticosus (Lindenb. \& Gottsche) Schiffn.

Leaves with a vitta.

Distribution: Japan, Malesia, Australia, Pacific.

\section{Thysananthus series Dendrolejeunea}

Plants dendroid, with creeping stoloniform stems and ascending leafy stems. Branching of leafy stems regularly pinnate. Lobule bases without appendage.

Type species: Thysananthus fruticosus (Lindenb. \& Gottsche) Schiffn.

Distribution: Malesia.

12. Thysananthus fruticosus (Lindenb. \& Gottsche) Schiffn. (Figs. 22-23)

in Engler \& Prantl, Nat. Pflanzenfam. 1, 3: 130. 1893. Bryopteris fruticosa Lindenb. \& Gottsche, Syn. Hepat. 737. 1847. Dendrolejeunea fruticosa (Lindenb. \& Gottsche) Lacout., Rev. Bryol. 35: 104. 1908. Caudalejeunea fruticosa (Lindenb. \& Gottsche) Steph., Sp. Hepat. 5: 14. 1912.-Type: IndONESIA. Java: Mt. Sajira, Blume s.n. (lectotype: STR!).

Bryopteris filicina (Sw.) Nees var. $\gamma$ fruticosa Gottsche et al., Syn. Hepat. 285. 1845, nom. nud. syn. fide Verdoorn (1934): 182.

Thysananthus manillanus Gottsche, Ann. Sci. Nat., Bot (ser. 4) 8: 342. 1857.-Type: PHILIPPINES. "Manilla, Gaudichaud 115" (holotype: PC; isotype: PC-hb. Bescherelle!). 
Bryopteris vitata Mitt., Fl. Vit: 411. 1873.-Type: AustraliA. Norfolk Island: Robinson s.n. (holotype: G!).

Thysanolejeunea lanceolata Steph., Hedwigia 35: 139. 1896. Thysananthus lanceolatus (Steph.) Steph., Sp. Hepat. 4: 796. 1912.-Type: PAPUA NEW GuINEA. Morobe: “Sattelburg”, Känbach 56 (holotype: G!).

Thysananthus sinclairii (Mitt.) Steph., Sp. Hepat. 4: 792. 1912. Lejeunea sinclairii Mitt., Bonplandia 10: 9. 1862.—Type: FIJ. "Insulae Vitienses” “inter nr. 843”, Seemann s.n., "in Herb. Gourlie et Mitten” Sinclair s.n. cf. Geissler \& Bischler (1987), syn. fide Verdoorn (1934): 183.

Thysananthus abietinus Steph., Sp. Hepat. 4: 794. 1912.-Type: New CALEDONIA. “Insula Oneiteum, 1882, Braitwaithe”s.n. (holotype: G!); Icon. Steph. n. 10165. Thysananthus lauterbachii Steph., Sp. Hepat. 4: 797. 1912.-Type: PAPUA NEW GuINEA. Madang: “Gogal”, Lauterbach 1060 (holotype: G!); Icon. Steph. n. 10193.

Thysananthus ovistipulus Steph., Sp. Hepat. 4: 798. 1912.-Type: PAPUA NEW GuINEA. Without location, Musgrave s.n. (holotype: G!); Icon. Steph. n. 10202.

Thysananthus bowienus Steph., J. \& Proc. Roy. Soc. New South Wales 48: 134. 1914.-Type: VAnUATU [“Novae Hebrides”]. Sanma: Santo, Watts 18 (holotype: G!); Icon. Steph. n. 10170.

Thysananthus densus Steph., Sp. Hepat. 6: 565. 1924.-Type: PAPUA NEW GuINEA. Milne Bay: Conway s.n. (holotype: G!); Icon. Steph. n. 10176.

Thysananthus eminens Gottsche ex Verd., Ann. Bryol. Suppl. 4: 183. 1934, nom. inval. [Art. 34.1 (c)], syn. fide Verdoorn (1934): 183.

Thysananthus ovilobulus Steph. ex Verd., Ann. Bryol. Suppl. 4: 183. 1934, nom. inval. [Art. 34.1 (c)], syn. fide Verdoorn (1934): 183.

Plants autoicous, with dendroid habit, having creeping stoloniform stems and upright, regularly pinnate branches, yellowish in herbarium specimens, up to $14.8 \mathrm{~cm}$ long $\times 1.8-2.1$ $\mathrm{mm}$ wide. Stems rather rigid; ventral merophyte 6-11 cell rows wide; in cross section roundorbicular in shape, 170-340 $\mu \mathrm{m}$ high $\times 135-300 \mu \mathrm{m}$ wide, composed of 30-62 epidermal cells, 25-50 subepidermal cells in 4-6 layers high surrounding 67-218 medullary cells in 920 layers high, epidermal cells not larger than medullary cells. Leaves imbricate, when dry suberect and convolute, when moist weakly concave, apical parts plane, not recurved; dorsal lobe asymmetrically ovate-falcate, $1.1-2.7 \times 0.5-1.3 \mathrm{~mm}$, apex acute, dorsal base cordate, dorsal margin with 2-4 triangular teeth, the teeth consisting of 3-7 cells, being 3-4 cells wide 
at base, apex of one cell, ventral margin plane, with 2-6 triangular teeth, the teeth consisting of 3-7 cells, being 3-4 cells wide at base, apex of one cell; cells elongate-hexagonal with acute ends, vitta present in midportion of lobe, extending to base, $2 / 3 \times$ lobe length, $8-10$ cell rows wide, 17-26 cells long, marginal cells 7.5-15 × 7.5-12.5 $\mu$ m, median cells 17.5-25 $\times$ 7.5-15 $\mu \mathrm{m}$, basal vitta cells $37.5-60 \times 12.5-22.5 \mu \mathrm{m}$, trigones cordate, often coalesced, intermediate thickenings $0-1$ per cell wall; oil bodies unknown. Lobules oblong, 0.1-0.5 $\times$ $0.1-0.3 \mathrm{~mm}, \pm 1 / 3 \times$ lobe length, appendage on surface of lobule base not developed; keel with appendages on both sides of stem; lobule apex transverse, not or shortly continuing into the ventral lobe margin, entire to with one triangular tooth, the tooth consisting of 3 cells, being 2 cells wide at base, apex of one cell. Underleaves imbricate, slightly squarrose, ovate, $0.5-1 \times$ 0.5-0.9 mm, 3-4× stem width, apex truncate to emarginate, with 8-12 triangular teeth, the teeth consisting of 7-9 cells, being 2-3 cells wide at base and ending in a row of 6-7 cells, bases cuneate-slightly auriculate, underleaf bases not adnate with leaves; cells 22.5-42.5 × 7.5-10 $\mu \mathrm{m}$. Androecia terminal-intercalary on lateral branches, bracts and bracteoles in 521(-38) pairs, bracts hypostatic, $0.6-1.3 \times 0.3-0.6 \mathrm{~mm}$, apex acute, margin entire; antheridia 2 per bract. Gynoecia with 1-2 lejeuneoid innovation forming monochasial or dichasial pattern; lobe lanceolate, 1.4-2 $\times 0.3-0.6 \mathrm{~mm}$, apex apiculate, margins in upper $1 / 3$ with triangular teeth, the teeth consisting of 3-10 cells, being 2-4 cells wide at base and ending in a row of 1-2 cells; lobule broadly ovate, 1/2× lobe length, apex apiculate, margins with triangular teeth, the teeth consisting 3-5 cells, being 2-3 cells wide at base and ending in a row of 1-2 cells; bracteole spathulate, $1.3-2 \times 0.6-0.8 \mathrm{~mm}$, apex truncate, $1 / 2 \times$ bracteole length with triangular teeth, the teeth consisting of 3-7 cells, being 2-3 cells wide at base, apex of one cell, margins recurved. Perianths oblong-cylindrical, 1.3-2.3 $\times 0.7-0.9 \mathrm{~mm}$, keels in upper $1 / 3$ with laciniate teeth, with $2-5$ cells long at apex; beak $32.5-75 \mu \mathrm{m}$ with $3-5$ cells long.

Chromosome number. Unknown.

Chemistry. Sesquiterpene alcohol guaia-6,9-dien-4 $\beta$-ol and the unidentified diterpenoid $\left(\mathrm{M}^{+}\right) 304,271(100)$, 105(90) as most characteristic components (Sukkharak et al., in press, under Dendrolejeunea fruticosa).

Additional illustrations. Thiers \& Gradstein (1989, p. 72, Fig. 27); Gradstein et al. (2002, p. 21, Fig. 11).

Distribution and ecology. Malesia, Australia (Queensland) and the Pacific region; 25$2000 \mathrm{~m}$; on tree trunks, twigs and rotten logs in rain forests (primary and secondary forests) and montane forests. 
Representative Specimens. Thailand. Phang Nga: Sri Phang Nga national park, Chantanaorrapint 2112 (PSU). Malaysia. JOHORE: Gg. Sumalayang, Chin 744 (SING).PAHANG: Ulu Cheneras, Burkill 15669(b) (SING); Kuala Tembeling, Holttum 20541 (SING).-SABAH: Danum valley conservation area, Ellis 38 (BM); 2 miles north of Kinabatangan river at Bukit Garam, Wood 1437 (BM-K); Sandakan, Sapagaya F. R., Kadir \& Enggoh 10564 (BM-K); Timbun Mata Island, Mapat river, Keith 7358 (BM-K); Tawau, “Kadir” A2023 (BM-K).-SARAWAK: Baram district, Evereth s.n. (G 2 packets); Mt. Dulit, Richards 2277 (BM-K, JE, SING).-SELANGOR: Hulu Langat, Congkat river, Ilkiu-Borges \& Yong 3026 (GOET). Singapore. Chan Chu Kan, Ridley s.n. (G). Indonesia. KaLIMANTAN: peak of Balikpapan, Meijer B1339e (BM-K 2 packets, G, PC, SING), B1391a (SING).SuMATRA: Engano Islands, “Modigliani” s.n., ex hb. Levier 152 (BM-K, G 3 packets, PC).SULAWESI: without location, “Kiese” s.n. (S 2 packets).-WESTERN NEW GUINEA: Bird's Head peninsula, van Royen \& Sleumer 7268 (BR, U); Mt. Arfak, Beccari s.n. (JE); Andai, Beccari s.n. (JE, U); "Bogaljim”, Missionare s.n. (S 3 packets); Padang, Blum s.n. (JE); Mt. Jaya, Edwards 4103A (BM). Philippines. Benguet: Baguio and vicinity, Robinson 2-107, Bureau of science no. 14101 (BM-K)._LAGUNA: Siniloan national botanical garden, Alvarez \& al 0-771073 (JE)._-Nueva ECIJA: without location, Santos 212 (JE).-QUEZON: Botanical garden of University of the Philippines Los Banõs, Onraedt 85.P.11304 (BR); Polillo, McGregor 2-39, 10499 (BM-K, G); ibid., Bureau of science no. 10495 (G); Tayabas, Robinson 89604 (G); Dimasingay, Baler, Santos 235 (JE).—SAMAR: Mt. Purog, Edãno s.n. (U).--Surigao Del SuR: Muni river, "Pahl” 85.P.11973 (BR).-TAYABas: without location, Robinson 89604 (BM-K). Papua New Guinea. CEnTrAL: Moroka, Jul-Aug 1893, Loria s.n., ex hb. Levier 109 (BM-K 2 packets, G 4 packets, PC); Koitaki plantation, Carr 12078, Hep. Sep. Crit. Verdoorn 449 (BM-K 3 packets, BR, C, G, GOET, JE, PC, SING 2 packets, U 2 packets); 30 miles north of Port Moresby, Robbins 4132 (JE); Angabanga river, Streimann \& Naoni 16213 (JE, LAE); Kuriva logging area, Streimann \& Vinas 14399, 14408, 14426, (JE, LAE), 14434 (BR, JE, LAE); road to Muscrave river, Streimann \& Naoni 15206 (JE), 15191, 15214, 15250 (JE, LAE).-EASTERN HiGHLANDS: Kassam pass, Streimann \& Umba 11431 (JE, LAE).—EAST SEPIK: Hawain river range, Robbins 2081 (JE); WewakAngoram, Robbins 2345 (JE); Hunstein river, Hoogland \& Craven 10.752 (JE 2 packets); Kassam pass, Streimann \& Umba 11451 (JE, LAE); Prince Alexander Mts., Robbins 2016 (JE)._MILNE BAY: Goodenough Island, Brass 22982 (JE); north slope of Mt. Dayman, Brass 22185 (JE).-MADANG: Lower Ramu-Atitau, Robbins 1433, 1691 (JE).-MOROBE: Busu river logging area, Weber s.n. (JE, U); Herzog Mts., Streimann \& Umba 11038, 11055 (LAE), 11054 (JE, LAE), 11053 (BR, JE, LAE); Gurakor creek, Lae-Bulolo road, Bellamy 
1248 (JE, LAE); logging area, $15 \mathrm{~km}$ Eeast of Bulolo, Streimann \& Bellamy 13184 (BR), 13152, 13184 (JE, LAE), 13762 (LAE); Gumi divide, head of gumi creek, Streimann 25733 (JE, LAE); Slate creek and Gumi creek divide, Streimann 13954 (BR); heads Hump, Streimann 17437, 17440 (JE); near Nauti village, Streimann \& Elix 26229 (JE); Nauti logging area, upper Watut river, Streimann \& Kairo 17245, 17263, Streimann 17321, 17327 (JE), 17309 (GOET, JE, LAE); Sattelberg, Clemens 264/e (JE); ibid., Jun 1988, Nyman s.n. (BMK, C 2 packets), Pöch s.n., Museo Hist. Natur. Vindobonensi 4035 (G, S 2 packets, U).NEW IRELAND: Mussau Island, Bismarck Archipelago, Kфie \& Olsen 2051, 2061 (C).-ORO: Managalase area, Pullen 5685 (JE).- SouTHERn HightLands: Batteri, Kagua-Erave road, Streimann 23433 (JE, LAE)._-WESt New BRITAIN: Willaumez Peninsula, Kolema 28 (JE); Mosa N.T.A., Lakemata reforest creek, Kolema 101 (JE); Honde-Laulimi T. R. P., Kolema 121 (JE).-WEStERn SePIK: headwaters of Kong Kong creek, Mundua 283 (JE). Solomon Islands. CENTRAL: Russel Islands, Dec 1935, Lever s.n. (BM-K). GuADALCANAL: without location, van Zanten 68-2360, 68-2370 (JE).

Cook Islands. Rarotonga, Gardner 72/e (JE). Vanuatu. New Hebrides, 1909, Bowie s.n. (BM). Fiji. RewA: Suva, Armstroy s.n. (G). Samoa. Upolu Island, graeffe 628, s.n. (G), Reinecke s.n. (G). American Samoa. Tuluita Island, Graeffe $664(\mathrm{G})$.

Reported from Australia, Queensland, Brown s.n. \& s.d. (NY) and Norfolk Island, Robinson s.n. \& s.d. (BM) by Thiers \& Gradstein (1989).

Thysananthus fruticosus was originally described as a species of Bryopteris and was placed in a separate subgenus Dendrolejeunea (of Lejeunea s.1.) by Spruce (1884). Lacouture (1908) raised Dendrolejeunea to generic range but this has not been followed by later authors who accepted Schiffner's attribution (1893) of T. fruticosus to Thysananthus. The genus Dendrolejeunea was reinstated for T. fruticosus again by Gradstein (1992a). Thysananthus fruticosus differs from other members of Thysananthus by its dendroid habit, having creeping stoloniform stems and upright, regularly pinnate branches. The species shares the presence of a vitta with T. mollis, T. montanus and T. retusus and was for this reason placed by Verdoorn (1934) in Thysananthus sect. Vittatae, which is equivalent to T. sect. Dendrolejeunea. However, the molecular results showed that D. fruticosa is a member of Thysananthus (Sukkharak et al., submitted).

Thysananthus series Sandeanthus (B. Thiers \& Gradst.) comb. nov. 
Thysananthus subg. Sandeanthus B. Thiers \& Gradst., Mem. New York Bot. Gard. 52: 66. 1989.

Type species: Thysananthus retusus (Reinw. et al.) B. Thiers \& Gradst.

Plants with projecting growth and irregularly pinnate branching. Lobule bases with appendages.

Distribution: Japan, Malesia, Australia, Pacific.

13. Thysananthus mollis Steph. (Figs. 24-25)

Sp. Hepat. 4: 798. 1912; Gradstein et al. (2002: 76).-—Type: PAPUA NEW GuINEA. Owen Stanley Range, Summit, 1889, McGregor s.n., (holotype: G!); Icon. Steph. nr. 10198.

Plants dioicous, with projecting growth, turning upwards and becoming ascending to erect, pale yellow in herbarium specimens, up to $5.7 \mathrm{~cm}$ long $\times 3-5 \mathrm{~mm}$ wide. Stems rather rigid; ventral merophyte 10-13 cell rows wide; in cross section round-orbicular in shape, 370-293 mm high $\times 270-298 \mu \mathrm{m}$ wide, composed of 38-57 epidermal cells surrounding 123225 medullary cells in 18-20 layers high, epidermal cells not larger than medullary cells. Leaves imbricate, when dry suberect and convolute or laterally appressed to the stem, when moist weakly concave, apical parts plane, not recurved; dorsal lobe symmetrically lanceolate, 2.2-2.8 $\times 0.8-1.2 \mathrm{~mm}$, apex apiculate, dorsal base auriculate, auricle $27-150 \times 62-150 \mu \mathrm{m}$, dorsal margin entire to with 3-10 teeth, the teeth consisting of 3-7 cells, being 2-3 cells wide at base and ending in a row of 1-2 cells, ventral margin plane or upcurved $1 / 2 \times$ leaf length, with 3-12 teeth, the teeth consisting of 3-7 cells, being 2-3 cells wide at base and ending in a row of 1-2 cells; cells elongate-hexagonal with acute ends, vitta cells present in midportion of lobe, extending to base, 2/3× lobe length, 18-21 cell rows wide, 27-30 cells long, marginal cells $7-10 \times 7-10 \mu \mathrm{m}$, median vitta cells $27-60 \times 7-10 \mu \mathrm{m}$, basal vitta cells $40-65 \times 10-17$ $\mu \mathrm{m}$, trigones cordate, often coalesced, intermediate thickenings $0-2$ per cell wall; oil bodies unknown. Lobules oblong, $0.2-0.4 \times 0.1-0.2 \mathrm{~mm}, 1 / 10-1 / 8 \times$ lobe length; appendages on surface of lobule base on both sides of stem; keel without appendage, lobule apex oblique, longly continuing into the ventral lobe margin, apex entire to with one elongate tooth, the tooth consisting of 5-6 cells, being 2-3 cells wide at base and ending in a row of 3-8 cells. Underleaves imbricate, slightly squarrose, broadly obovate to spathulate, (0.8-)1.3-2 ×0.6$1.2 \mathrm{~mm}, 3-5 \times$ stem width, apex emarginate-lunulate, plane or plicate, entire or with 12-13 triangular teeth, the teeth consisting of 3-10 cells, being $2-4$ cells wide at base and ending in 
a row of 1-2 cells, bases cuneate, underleaf bases not adnate with leaves; cells $25-37 \times 5-7$ $\mu \mathrm{m}$. Androecia terminal-intercalary on lateral branches, bracts and bracteoles in $4-10(-23)$ pairs, bracts hypostatic, $0.6-2.3 \times 0.3-0.8 \mathrm{~mm}$, apex acute, margins entire; antheridia 2 per bract. Gynoecia with 1-2 lejeuneoid innovation forming monochasial or diochasial pattern; lobe lanceolate, 3.1-3.4 $\times 0.8-1.2 \mathrm{~mm}$, apex apiculate, margins in upper $2 / 3$ with laciniate teeth with 2-4 cells long at apex; lobules broadly ovate, $1 / 2 \times$ lobe length, apex bifid, margin with laciniate teeth with 1-4 cells long at apex; bracteoles spathulate, 2.2-2.5 × 1-1.6 mm, apex emarginate, $1 / 2 \times$ bracteole length with laciniate teeth with $1-4$ cells long at apex, margins plane. Perianths oblong-cylindrical, $2.5-3.2 \times 0.8-1.3 \mathrm{~mm}$, keels in upper 1/3 with triangular teeth, the teeth consisting of 3-14 cells, being 2-5 cells at base and ending in a row of 1-2 cells; beak 50-65 $\mu \mathrm{m}$ with 4-5 cells long.

Chromosome number. Unknown.

Chemistry. Poor in sesquiterpenoids (mainly caryophyllene and alloaromadendrene), rich in diterpenoid content, sterols (Gradstein et al., 1985).

Additional illustrations. Gradstein et al. (2002, p. 76, Fig. 48).

Distribution and ecology. Endemic to Western Melanesia; 1200-3100 m; on roots, bark of trees, twigs, fallen branches and logs in the understory of montane forests.

Representative Specimens. Papua New Guinea. Central: The type-Chimb: trail from Keglsugl to Pindaunde lakes, Gradstein 4145 (U); trail from Keglsugl to Pindaunde lakes, Gradstein \& Sipman 8304 (G).-EASTERN HighLANDS: Lipizauga Botanical Sanctuary, Thiers 3699 (U); Daulo Pass, Streimann 18003 (JE, W)._EngA: Mape creek, Mt. HagenWapenamanda, Streimann 21646 (JE, LAE).-MorobE: Ogeramnang, Clemens 5527/H-d; ibid., 17 Feb 1937, Clemens s.n. (JE); near Kaindi village, 23 Nov 1975, Inoue s.n. (U); Mt. Kaindi, Gradstein 3779, 3794, 3884, 3980 (U), 3798 (G, U), 3795 (G, U 2 packets), 3792 (G, GOET, U 3 packets), Gradstein \& Sipman 7865, 7899 (G), Schuster 67-6319, 67-6361, 676364 (JE); Slate-Gumi creeks divide, Streimann 13954, 33938 (JE), 13817 (LAE), 13921, 13924, 13927 (JE, LAE); Wagau-Malolo track, Streimann 19565 (JE); Gumi divide, head of Gumi creek, Streimann 25132, 25305 (JE), Streimann 22786 (LAE); Spreader divide, Streimann 25974, 25993, 26004, 26014 (JE), 26021 (JE, LAE), Streimann \& Tamba 11883, 11905, 11914 (JE, LAE), 11957, 11970, 11980, 11992 (LAE); Bulolo-Watut divide, Streimann 25032, 25220 (JE), Streimann \& Bellamy 13049 (JE), Manki Trig, Streimann \& Bellamy 12971 (LAE); Wau-Salamaua track, Streimann 25675 (JE, LAE, S, W); Mt. Kaindi road, Streimann 33397 (JE); Araulu logging area, Streimann 13560 (JE).-SOUTHERN HIGHLANDS: Tambul-Mendi road, Streimann 26800 (JE); Iaro river, Streimann 23855, 23888 
(JE, LAE); Lama sawmill, Streimann 26631 (JE).-WESTERn HiGHLANDS: Baiyer river-Ruti road, Jimi valley, Streimann 22075 (JE), 22239 (LAE), 22008 (JE, LAE).—WESTERN SEPIK: Amisumbil, Eliptamin, Macrosimnok 27 (JE, LAE).

Reported from the Solomon Islands by Gradstein et al. (2002).

Thysananthus mollis varies in leaves and underleaves, which are sharply toothed to entire. Thysananthus mollis may be confused with $T$. fruticosus but the latter species is dendroid, has regularly pinnate branching, keels of all leaves with appendages, laciniate perianth teeth, 2-5 cells long and is autoicous. Thysananthus mollis is closely related to $T$. montanus; differences are discussed under the latter species.

14. Thysananthus montanus Gradst. et al. (Fig. 26)

Acta Bot. Fenn. 174: 77. 2002.-Type: PAPUA NEW GuINEA. Morobe: Lake Wamba, $5 \mathrm{~km} \mathrm{~S}$ of Teptep airstrip, Teptep-Wantuat trail $10 \mathrm{~km} \mathrm{~S}$ of Teptep, open montane forest on ridge sloping $\mathrm{NE}$, alt. 2550-2700 m, 6 $2.5^{\prime} \mathrm{S} 146^{\circ} 33^{\prime} \mathrm{E}$, Koponen 33958 b (holotype: H!).

Plants dioicous, with projecting growth, turning upwards and becoming ascending to erect, pale brown in herbarium specimens, up to $3.5 \mathrm{~cm}$ long $\times 1.5-2.6 \mathrm{~mm}$ wide. Stems rather rigid; ventral merophyte 8-10 cell rows wide; in cross section round-orbicular in shape, 215-240 $\mu \mathrm{m}$ high $\times 303-329 \mu \mathrm{m}$ wide, composed of 43-48 epidermal cells surrounding 141150 medullary cells in 14-17 layers high, epidermal cells not larger than medullary cells. Leaves imbricate, when dry suberect and convolute, when moist weakly concave, apical parts plane, not recurved; dorsal lobe symmetrically oblong, 1.6-1.8 $\times 0.6-0.8 \mathrm{~mm}$, apex acuteapiculate, margin entire, dorsal base auriculate, auricle 57-96 $\times 57-76 \mu \mathrm{m}$, ventral margin upcurved $1 / 2 \times$ leaf length; cells elongate-hexagonal with acute ends, vitta cells present in midportion of lobe, extending to base, $2 / 3 \times$ lobe length, $8-17$ cell rows wide, 13-20 cells long, marginal cells 10-12 ×5-7 $\mu \mathrm{m}$, median vitta cells $25-45 \times 5-7 \mu \mathrm{m}$, basal vitta cells 50$67 \times 10-15 \mu \mathrm{m}$, trigones cordate, often coalesced, intermediate thickenings 0-2 per cell wall; oil bodies unknown. Lobules rectangular, $0.8-1 \times 0.3-0.4 \mathrm{~mm}, 1 / 4-1 / 3 \times$ lobe length; appendages on surface of lobule base on both sides of stem; keel without appendage; lobule apex oblique, longly continuing into the ventral lobe margin, apex with one elongate tooth, the tooth consisting of 7-9 cells, being 2-3 cells wide at base and ending in a row of 6-7 cells. Underleaves imbricate, slightly squarrose, spathulate, $1.2-1.3 \times 0.6-0.7 \mathrm{~mm}$, apex 
round, plane, margins entire, bases cuneate, underleaf bases not adnate with leaves; cells 27$37 \times 2-5 \mu \mathrm{m}$. Androecia terminal-intercalary on lateral branches, bracts and bracteoles in 613(-20) pairs, bracts hypostatic, $0.7-0.9 \times 0.2-0.5 \mathrm{~mm}$, apex acute, margins entire; antheridia 2 per bract. Gynoecia with 2 lejeuneoid innovations forming a dichasial pattern; lobe lanceolate, $2.7-2.8 \times 0.8-0.9 \mathrm{~mm}$, apex acute, margins entire or in upper $2 / 3$ with triangular teeth, the teeth consisting of 3-5 cells, being 2-3 cells wide at base and ending in a row of 12 cells; lobules broadly ovate, $1 / 2 \times$ lobe length, apex bifid, margin with triangular teeth, the teeth consisting of 3-5 cells, being 2-3 cells wide at base and ending in a row of 1-2 cells; bracteoles spathulate, $2.4-2.5 \times 0.7 \mathrm{~mm}$, apex emarginate to shortly bifid, entire or $1 / 2 \times$ bracteole length with teeth, the teeth consisting of 3-5 cells, being 2-3 cells wide at base and ending in a row of 1-2 cells, margins plane. Perianths oblong-cylindrical, 2.6-2.7 $\times 0.7-0.8$ $\mathrm{mm}$, keels entire; beak 62-65 $\mu \mathrm{m}$ with $4-5$ cells long.

Chromosome number. Unknown.

Chemistry. Unknown.

Additional illustrations. Gradstein et al. (2002, p. 78, Fig. 49).

Distribution and ecology. Endemic to Papua New Guinea; 1900-2300 m; on tree trunks, lianas and branches in open montane forests.

Representative Specimens. Papua New Guinea. Eastern Highlands: Gahavisuka National Park, Thiers 3656 (G).-MOROBE: Gumi divide, Streimann 22707 (JE, LAE); Mt. Kaindi, Streimann 22511 (LAE); Araulu logging area, Streimann 13639 (LAE); Nauti logging area, upper Watut river, Streimann 17150 (LAE).

Thysananthus montanus varies in the female bracts and bracteoles, which are entire to dentate. The type specimen was previously identified as Thysananthus planus (= T. retusus). By its oblong, entire leaves T. montanus approaches $T$. retusus but differs from the latter by (1) leaves when dry convolute (widely spreading, loosely reflexed or plane in T. retusus), (2) dorsal base auriculate (cordate in T. retusus), (3) leaf cells elongate-hexagonal, vitta cells 817 cell rows wide (subisodiametric, 4-6 in T. retusus), (4) being dioicous (autoicous in $T$. retusus), and (5) entire pereianths (toothed perianths in T. retusus). Thysananthus montanus is closely related to $T$. mollis. The latter species differs essentially by its leaf, which is lanceolate in outline, emarginate-lunulate underleaf apex and toothed perianths.

15. Thysananthus retusus (Reinw. et al.) B. Thiers \& Gradst. (Figs. 27-28A, C-E) 
Mem. New York Bot. Gard. 52: 67. 1989; Gradstein et al. (2002: 78). Jungermannia retusa Reinw. et al., Acta Phys.-Med. Acad. Caes. Leop.-Carol. Nat. Cur. 12: 214. 1824; Nees (1830: 214; var. $\alpha$ ). Ptychanthus retusus (Reinw. et al.) Nees, Syn. Hepat. 292. 1845.-Type: InDONESIA. Java [“inter muscos Javae insulae, rarior']: Blume s.n. (holotype: STR; isotypes: S!, W 3 packets!).

Thysananthus planus Sande Lac., Ned. Kruidk. Arch. 3(4): 419. “1855”; Lacoste (1856: 55); Mizutani (1969: 139), syn. fide Thiers \& Gradstein (1989): 67.— Type: INDONESIA. Java: Junghuhn s.n. (holotype: L!).

Mastigolejeunea wattsiana Steph., Sp. Hepat. 4: 780. 1912.-Type: AustraLIA. New South Wales: Richmond River, Fernleigh, tree, 2 Aug 1900. W.W. Watts s.n. (holotype: G!); Icon. Steph. nr. 7467, syn. nov.

Thysananthus subplanus Steph., Sp. Hepat. 4: 790. 1912.-—Type: PHILIPPINES. Bataan: Mt. Mariveles, E. D. Merrill 3984 (holotype: G!); Icon. Steph. nr. 10217.

Brachiolejeunea grossivitta Steph., J. \& Proc. Roy. Soc. New South Wales 48: 10. 1914.-Type: VAnUATU [New Hebrides]. “Aneityum”, Gunn s.n. (isotype: JE!).

Thysananthus furcatus Herzog, Ann Bryol. 4: 87. 1931.-Type: PHILIPPINES. Benguet:

“Baguio, 20.V.15, C. J. Baker (n. 7004) n. 7053” (syntype: JE!).

Thysananthus flavescens (S. Hatt.) Gradst., Trop. Bryol. 4: 13. 1991. Archilejeunea flavescens S. Hatt., Bull. Tokyo Sci. Mus. 11: 95. 1944. Leucolejeunea flavescens (S. Hatt.) S. Hatt., J. Hattori Bot. Lab. 8 : 33. 1952. Mastigolejeunea flavescens (S. Hatt.) Mizut., J. Hattori Bot. Lab. 24: 159. 1961.—Type. JAPAN. Osumi: Satamura, Hetka, on bark, April 18, 1939. S. Hattori 2399 (isotype: NICH!), syn. nov. Thysananthus australis (Steph.) B. Thiers \& Gradst., Mem. New York Bot. Gard. 52: 66. 1989. Archilejeunea australis Steph., Sp. Hepat. 4: 734. 1911.-Type: Australia. New South Wales: Back of Wickham's farm near Ballina, on tree, 3 Jun 1902, W. W. Watts 415 (holotype: G!), syn. nov.

Plants autoicous, with projecting growth, turning upwards and becoming ascending to erect, dull green in the field, yellowish to reddish brown in herbarium specimens, up to $1.6 \mathrm{~cm}$ long $\times 1-2.5 \mathrm{~mm}$ wide. Stems rather fragile, ventral merophyte 7-9 cell rows wide; in cross section round-orbicular in shape, 119-125 $\mu \mathrm{m}$ high $\times$ 92-98 $\mu \mathrm{m}$ wide, composed of 18-21 epidermal cells surrounding 27-34 medullary cells in 8-10 layers high, epidermal cells not larger than medullary cells. Leaves contiguous to slightly imbricate; when dry wide spreading and flat, dorsal lobe symmetrically ovate to ligulate, $1.3-1.5 \times 0.4-0.6 \mathrm{~mm}$, apex acuteshortly apiculate, margins entire, dorsal base cordate, ventral margin plane; non-vitta cells 
subisodiametric to isodiametric, vitta cells present in midportion of lobe, extending to base, 2/3× lobe length, 4-6 cell rows wide, 12-18 cells long, marginal cells 5-7 ×5-7 $\mu \mathrm{m}$, median cells $12-15 \times 10-12 \mu \mathrm{m}$, basal vitta cells $35-52 \times 12-15 \mu \mathrm{m}$, vitta cell trigones coalesced, intermediate thickenting 1-2(-3) per cell walls, non-vitta cells trigones and intermediate thickening faint; oil bodies 3-5 per non-vitta cell and 4-8 per vitta cell. Lobules oblong, 0.2$0.3 \times 0.1-0.2 \mathrm{~mm}, 1 / 4-1 / 3 \times$ lobe length; appendages on surface of lobule base on both sides of stem; keel without appendage; lobule apex oblique, longly continuing into the ventral lobe margin, apex with one elongate tooth, the tooth consisting of $4-5$ cells, being 2-3 cells wide at base and ending in a row of 1-6 cells. Underleaves slightly imbricate, slightly squarrose, obovate, $0.3-0.6 \times 0.3-0.5 \mathrm{~mm}, 3-4 \times$ stem width, apex truncate to emarginate, recurved, margins entire, bases cuneate, underleaf bases free or adnate with leaves on one side, on lefthand side for right branches and right-hand side for left branches; cells 12-15 $\times 5-7 \mu \mathrm{m}$. Androecia terminal-intercalary on lateral branches, bracts and bracteoles in 3-10 pairs, bracts hypostatic, $0.9-1 \times 0.3-0.4 \mathrm{~mm}$, apex acute to apiculate, margins entire, antheridia 2 per bract. Gynoecia with 1-2 lejeuneoid innovations forming monochasial or dichasial pattern or both; lobe ligulate, $1.6-1.7 \times 0.6-0.7 \mathrm{~mm}$, apex apiculate, magins entire or in upper 1/3 with triangular teeth, the teeth consisting of 3-5 cells, being 2-3 cells wide at base, apex of one cell; lobules broadly ovate, 1/3-1/2× lobe length, apex apiculate to obscurely bifid, with triangular teeth, the teeth consisting of 3-5 cells, 2-3 cells wide at base and ending in a row of 1-2 cells; bracteoles ligulate, 0.9-1.4 × 0.3-0.6 mm, apex bifid, entire or toothed along margins, the teeth consisting of 3-7 cells, being 2-3 cells wide at base, apex of one cell, slightly recurved at base, margins plane. Perianths obovate, $0.8-1 \times 0.4-0.6 \mathrm{~mm}$, keels in upper 1/3 with triangular teeth, the teeth consisting of 3-5 cells, being 2 cells wide at base, apex of one cell; beak $30-45 \mu \mathrm{m}$ with $3-5$ cells long.

Chromosome number. Unknown.

Chemistry. Pinguisane sesquiterpenoids, unidentified diterpenoid $\left(\mathrm{M}^{+}\right) 318,81(100)$, 206(98) (Sukkharak et al., in press) and sterols (Gradstein et al., 1985, under Thysananthus fruticosus).

Additional illustrations. Hattori (1944, p. 95, Fig. 60; p. 96, Fig. 61 as Archilejeunea flavescens); Mizutani (1961, p. 160, Fig. VIII. as Mastigolejeunea flavescens); Thiers \& Gradstein (1989, p. 70, Fig. 26; p. 68, Fig. 25 as Thysananthus australis); Gradstein et al. (2002, p. 79, Fig. 50).

Distribution and ecology. India (Uttarakhand), Southern Japan, Malesia, Australia (Queensland and New South Wales), and the Pacific region; there is a doubtful records from Mascarene Islands by Miller et al. (1983) (fide Thiers \& Gradstein, 1989), which may have 
been mislabeled or misidentified; $125-1700 \mathrm{~m}$; on shaded stems of treelets and tree trunks in the Eucalyptus sp. dominated grasslands, and in the understory of rain forests and montane forests.

RePresentative SPecimens. India. UtTarakhand: Mussoorie, Sep 1930, Chopra s.n., Hep. Sel. Crit. Verdoorn 260 (JE). Japan. KAGOSHIMA: type of Thysananthus flavescens; a pass between Hanaze and Hekka, Mizutani 41481 (U), s.n., Hep. Jap. Exs. Mizutani 628 (BM-K). Thailand. NAKHON Si Thammarat: Mt. Khao Luang, Tagawa \& Kitagawa T4728, T4754, T5169, T5179, T5216, T5219 (G); Mt. Khao Nan Yai, Sukkharak 44, 291, 423 (BCU); San Yen, 19 Feb 2009, Chantanaorrapint s.n. (PSU), Sukkharak 733, 741, 743 (BKF, GOET). Indonesia. JAVA: Pantjar, Dec 1893, Schiffner s.n., Hep. Sel. Crit. Verdoorn 284 (BM-K 2 packets, BR, C, G 2 packets, GOET, JE, PC, SING, U); Bogor, 1843, collector unknown (S); without location, Lehman s.n. (S); Mt. Gede-Pangrango National Park, Haerida 1 H811 (BZ). Philippines. BataAn: Mt. Mariveles, Merrill 3984 (BM-K)._Benguet: Baguio and vicinity, 19 May 1191, Robinson s.n. (BM).-DAVAO ORIENTAL: Aliwagwag falls, “Georges-Pahl” 86.P.12004 (BR). Papua New Guinea. CENTRAL: Angabanga river, Streimann \& Naoni 16136 (JE, LAE).-MoroBE: Kunai Creek, Gradstein 3963 (G 2 packets, U 2 packets), 3980 (U); Mt. Missim, Gradstein \& Sipman 7929 (G), Gradstein 3833a (U); Situm logging area, Streimann 41733 (JE); Herzog Mts., Streimann \& Umba 10923 (JE, LAE), 10834, 10994 (LAE); Busu-Butibum ridge, Streimann 22679 (JE, LAE)._EAST NEW BritAIN: Nakanai Mts., H. Streimann 40492, 40547 (JE). Solomon Islands. GuADALCANAL: Mt. Gallego, 16 Sep 1966, Dennis 20025b (JE), s.n. (S); Mt. Popemanaseu, van Zanten 682545/b2 (JE).

Australia. New South WALES: type of Thysananthus australis; Baliina, Watts 17 (NSW); Protestors falls, Nightcap rang national park, Renner 1492 (NSW); Minyon Falls, Nightcap Range National park, 20 Oct 2009, Brown s.n. (NSW); 6.6 km south-southwest of Alstonville, Victoria Park Nature Reserve, 21 Oct 2009, Brown s.n. (NSW); Cambden Haven state forest, Streimann 38462 (JE).-QuEEnsLAnd: Big Tableland, Streimann 30895 (JE); near Mt. Walker, Streimann 30989 (JE); main coast range, Mary L.A., Streimann \& Gray 27135 (JE); Mossman Gorge national park, Thiers \& Halling 2560 (U); Bellenden Ker National park, Thiers 2395 (U); McDowell range north of the Daintree river, Hicks 11495 (U); Birthday creek (Townsville university experimental plot), Pócs \& Streimann 9972/AQ (GOET); Daintree National Park, Pócs \& Streimann 9991/A (G); Tully Gorge, Renner 1808 (NSW); Second stream ford, Cardwell state forest, Renner 1653 (NSW); Finch Hatton Gorge, Eungella National park, Renner 1514, 1516, 1519 (NSW). 
Vanuatu. Type of Brachiolejeunea grossivitta. Fiji. CAKAUdrove: Mt. Uluigalau, Degelius P-223 (JE, S), P-234/d (S).—RA: Navai, Hürlimann T1019e, T1021b (G); ibid., Mt. Victoria, Hürlimann T1082a (G). Samoa. Upolu, Schultze-Motel 3078 (JE), Rechinger 3272 (BM); Tutuila, Stevenson 14946, 14982 (JE). American Samoa. Tutuila, Stevenson 14946, $14982(\mathrm{JE})$.

Thysananthus retusus varies in the length of the lobule tooth, which may be 1-6 cells long. This species is a small and rather fragile plant which differs from other species of the genus, including (1) leaves widely spreading, loosely reflexed or plane when dry, (2) leaf cells subisodiametric with confluent trigones, and (3) vitta cells 4-6 cell rows wide.

\section{Key to the varieties of $T$. retusus}

Lobule $2 \times$ longer than wide 15a. T. retusus subsp. retusus

Lobule $5 \times$ longer than wide 15b. T. retusus subsp. sellingii

\section{5a. Thysananthus retusus subsp. retusus}

see under the species

15b. Thysananthus retusus subsp. sellingii (Herzog) comb. nov. (Fig. 29: B, G) Thysananthus sellingii (Herzog) Hürl., Bauhinia 9: 168. 1989. Mastigolejeunea sellingii Herzog, Ark. Bot. 3: 60. 1953.-Type: New CALEdONIA. South: slope above N. branch of Yaté River, humid forest with Dacrydium, O. Selling 44 (holotype: JE!; isotypes: S 2 packets!).

Thysananthus retusus subsp. sellingii differs from subsp. retusus in the much greater length of lobule, which is $5 \times$ longer than wide. Thysananthus sellingii is treated here as a subspecies of $T$. retusus because it differs from the latter by only one diagnostic morphological character and by its different geographical range (see chapter Classification).

Distribution and ecology. Endemic to New Caledonia; 400-700 m; on tree trunks in rain forests.

Representative Specimens. New Caledonia. South: Mé Amméri, Guillaumin \& Baumann 8902, 9136 (G, GOET); Rivière Blanche, Guillaumin \& Baumann 11900 (G, 
GOET); Rivière Bleue, Guillaumin \& Baumann 10893 (GOET); Koghis Mts., Bouo summit, Hürlimann 2111 (G, GOET, U); Pourina, Hürlimann 2647c (GOET).

Thysananthus subgenus Mastigolejeunea (Spruce) comb. nov.

Mastigolejeunea (Spruce) Schiffn., in Engler \& Prantl, Nat. Pflanzenfam. 1, 3: 129. 1893. Lejeunea subg. Mastigolejeunea sect. Trigonolejeunea Spruce, Trans. \& Proc. Bot. Soc. Edinburg 15: 100. 1884.

Type species: Thysananthus auriculatus (Wils.) comb. nov. (= Mastigolejeunea auriculata (Wils.) Schiffn.)

Characters as in Thysananthus except for the perianths which are always entire and the elaters which are presumably 72 per capsule (Gradstein, 1994), vs. 66 in subg. Thysananthus.

Distribution: tropical America, Africa, Indochina, Malesia, Australia, Pacific.

The species currently accepted in Mastigolejeunea are briefly listed here and transferred to Thysananthus. A full treatment of the subg. Mastigolejeunea should be the subject of future work.

16. Thysananthus auriculatus (Wils.) comb. nov.

Mastigolejeunea auriculata (Wils.) Schiffn., in Engler \& Prantl, Nat. Pflanzenfam. 1, 3: 129. 1893; Schuster (1980: 729); Gradstein (1994: 76). Jungermannia auriculata Wils., in Drummond, Musci Amer. Exsicc. (Southern States) nr. 170. 1841. Lejeunea auriculata (Wils.) Sullivant, in Gray, Manual Bot. 2: 699. 1856. Ptychocoleus auriculatus (Wils.) Trevisan, Mem. Reale Ist. Lomb. Sci. Mat. Nat. 3, 4: 405. 1877. Marchesinia auriculata (Wils.) Kuntze, Revis. Gen Pl. 2: 837. 1891. Phragmicoma versicolor Lehm. \& Lindenb., Syn. Hepat. 297. 1845, nom. superfl. fide Gradstein 1994.-Type: U.S.A. Louisiana: New Orleans, Drummond s.n., Musci Americani (Southern States) 170 (holotype: BM!; isotypes: MANCH, PC).

Description. Fl. Neotrop. Monogr. 62: 76-81 (1994).

Illustrations. Gradstein (1994, p. 78, Fig. 21).

Distribution. Tropical America, Africa.

17. Thysananthus calcaratus (Steph.) comb. nov. 
Mastigolejeunea calcarata (Steph.) Verd., Blumea 1: 218-230. 1934; Thiers \& Gradstein (1989: 44). Archilejeunea calcarata Steph., Sp. Hepat. 4: 724. 1911.

Phragmicoma calcarata Mitt., in Seemann, Fl. Vit. 413. 1873, hom. illeg., non Mont., 1843.-Type: FIJI. Ovalau: Seemann s.n. (holotype: NY).

Description. Mem. New York Bot. Gard. 52: 44, 46 (1989).

Illustrations. Thiers \& Gradstein (1989, p. 45, Fig. 16);

Distribution. Australia (Queensland) and Fiji.

18. Thysananthus floreus (Mitt.) comb. nov.

Mastigolejeunea florea (Mitt.) Paris, Rev. Bryol. 33: 42. 1906; Wigginton (2004:

273). Phragmicoma florea Mitt., J. Linn. Soc., Bot. 22: 323. 1886 “1887”.—

Type: "Niger”. cf. Geissler \& Bischler (1985).

Description. E. W. Jones's Liverwort and Hornwort Flora of West Africa: 273 (2004).

Illustrations. Vanden Berghen (1949).

Distribution. West Africa.

19. Thysananthus humilis (Gottsche) comb. nov.

Mastigolejeunea humilis (Gottsche) Schiffn., in Engler \& Prantl, Nat. Pflanzenfam. 1, 3: 129. 1893; Mizutani (196: 156); Mizutani (1986: 281). Phragmicoma humilis Gottsche, in Gottsche et al., Syn. Hepat. 299. 1845. Ptychocoleus humilis (Gottsche) Trevisan, Mem. Reale Ist. Lomb. Mat. Nat. 3, 4: 405. 1877. Lejeunea humilis (Gottsche) Spruce, Trans. \& Proc. Bot. Soc. Edinburg 15: 101. 1884.-Type: INDONESIA. Java: Junghuhn s.n. (isotypes: G, $\mathrm{W})$.

Description. J. Hattori Bot. Lab. 61: 281-283 (1986).

Illustrations. Mizutani (1961, p. 157, Fig. VII); Mizutani (1986, p. 282, Fig. 1); Gradstein et al. (2002, p. 42, Fig. 24 as Mastigolejeunea auriculata).

Distribution. India, Japan, Indochina, Malesia, Pacific

\section{Thysananthus integrifolius Steph.}

Sp. Hepat. 4: 788. 1912. Mastigolejeunea integrifolia (Steph.) Verd., Blumea 1: 239. 1934.-Type: Australia. Torres Straits: Possession Island, Aug 1897, Micholitz s.n. (holotype: G!; isotype: FH); Icon. Steph. nr. 10188. 
Mastigolejeunea indica Steph., Sp. Hepat. 4: 776. 1912; Mizutani (1986: 295); Thiers

\& Gradstein (1989: 46); Gradstein et al. (2002: 43).-Type: INDIA. Nicobar Island: Man s.n., ex hb. Levier 40 (holotype: G).

Description. Mem. New York Bot. Gard. 52: 46, 48 (1989).

Illustrations. Mizutani (1986, p. 296, Fig. 8 as Mastigolejeunea indica); Thiers \& Gradstein (1989, p. 47, Fig. 17 as M. indica); Gradstein et al. (2002, p. 43, Fig. 25 as M. indica).

Distribution. India (Nicobar Island), China (Yunnan), Malesia, Australia.

Thysananthus integrifolius was treated as a synonym of Mastigolejeunea indica by Thiers \& Gradstein (1989). However, since the two species were described on the same date (5 March 1912) I have chosen the name Thysananthus integrifolius Steph. as the correct name for this species, to avoid the introduction of a new name.

\section{Thysananthus innovans (Spruce) comb. nov.}

Mastigolejeunea innovans (Spruce) Steph., Sp. Hepat. 4: 765. 1912; Gradstein (1994: 81). Lejeunea innovans Spruce, Trans \& Proc. Bot. Soc. Edinburgh 15: 103. 1884.-Type: BrazIL. Amazonas: Rio Uaupés, Panuré, “ad arborum truncos", Spruce L42 (holotype: MANCH; isotype: BM); Icon. Steph. n. 7403.

Description. Fl. Neotrop. Monogr. 62: 81-82 (1994).

Distribution. Brazil (Amazonas), French Guiana.

22. Thysananthus ligulatus (Lehm. \& Lindenb.) comb. nov.

Mastigolejeunea ligulata (Lehm. \& Lindenb.) Schiffn., in Engler \& Prantl., Nat. Pflanzenfam. 1, 3: 129. 1895; Mizutani (1986: 285); Thiers \& Gradstein (1989: 48); Gradstein et al. (2002: 44). Jungermannia ligulata Lehm. \& Lindenb., Nov. Stirp. Pug. 6: 39. 1834. Ptychanthus ligulatus (Lehm. \& Lindenb.) Nees, Nat. eur. Leberm. 3: 212. 1838. Phragmicoma ligulata (Lehm. \& Lindenb.) Gottsche et al., Syn. Hepat. 301. 1845. Lejeunea ligulata (Lehm. \& Lindenb.) Mitt., J. Proc. Linn. Soc. Bot. 5: 110. 1861.-Type: MALAYSIA. "Pulo Penang", collector unknown, "Herb. Hook. 1832" (holotype: S; isotypes: G, L, NY, S, W-hb. Lindenberg 6022).

Description. Mem. New York Bot. Gard. 52: 48-50 (1989).

Illustrations. Mizutani (1986, p. 286, Fig. 3); Thiers \& Gradstein (1989, p. 49, Fig. 18); Gradstein et al. (2002, p. 45, Fig. 26). 
Distribution. Malesia, Australia, Pacific.

23. Thysananthus plicatiflorus (Spruce) comb. nov.

Mastigolejeunea plicatiflora (Spruce) Steph., Sp. Hepat. 4: 766. 1912; Gradstein (1994: 82). Lejeunea plicatiflora Spruce, Trans \& Proc. Bot. Soc. Edinburgh 15: 104. 1884.-Type: Venezuela. Amazonas: San Carlos del Ro Negro, “ad arbores", Spruce, Hapaticae Amazonicae et Andinae 1543 (lectotype, designated by Gradstein, 1994: MANCH 15909; isolectotypes: BM, G, W); Icon. Steph. n. 7405 .

Description. Fl. Neotrop. Monogr. 62: 82-83 (1994).

Distribution. Northern South America (Amazonia, Guianas, etc.)

24. Thysananthus reconditus (Steph.) comb. nov.

Mastigolejeunea recondita (Steph.) Mizut., J. Hattori Bot. Lab. 32: 134. 1969; Gradstein et al. (2002: 46). Ptycholejeunea recondita Steph., Hedwigia 35: 122. 1896. Brachiolejeunea recondita (Steph.) Steph., Sp. Hepat. 5: 134. 1912.-Type: PHILIPPINES. cf. Mizutani (1969).

Description. Acta Bot. Fenn 174: 46 (2002).

Illustrations. Mizutani (1969, p. 135, Fig. IV); Gradstein et al. (2002, p. 47, Fig. 27).

Distribution. Eastern Malesia.

25. Thysananthus recurvifolius (Mizut.) comb. nov.

Mastigolejeunea recurvifolia Mizut., J. Hattori Bot. Lab. 61: 294. 1986.-Type: Malaysia. Sabah: Batu Puteh, on limestones, G. Shea 3278 (holotype: NICH). Description. J. Hattori Bot. Lab. 61: 294-295 (1986).

Illustrations. Mizutani (1986, p. 295, Fig. 7).

Distribution. Malaysia (Sabah).

26. Thysananthus repletus (Taylor) comb. nov.

Mastigolejeunea repleta (Taylor) A. Evans, Mem. Torrey Bot. Club 8: 131. 1902; Mizutani (1986: 283); Gradstein et al. (2002: 46). Lejeunea repleta Taylor, London J. Bot. 5: 392. 1846.-Type: INDIA. Madras, Wight s.n. (isotypes: G, W) Description. J. Hattori Bot. Lab. 61: 283-285 (1986).

Illustrations. Mizutani (1986, p. 284, Fig. 2); Gradstein et al. (2002, p. 48, Fig. 28). Distribution. Indochina, Malesia. 
27. Thysananthus truncatus (Mizut.) comb. nov.

Mastigolejeunea truncata Mizut., J. Hattori Bot. Lab. 61: 292. 1986; Gradstein et al. (2002: 48).- - Type: MALAYSIA. Sabah: Madai cave, SW of Lahad Datu, East Coast, alt. 30-70, upper surface of rock, 1963, Iwatsuki 5426 (holotype: NICH). Description. J. Hattori Bot. Lab. 61: 292-294 (1986).

Illustrations. Mizutani (1986, p. 293, Fig. 6); Gradstein et al. (2002, p. 49, Fig. 29).

Distribution. Malesia.

28. Thysananthus undulatus (Gradst. \& Grolle) comb. nov.

Mastigolejeunea undulata Gradst. \& Grolle, in Hiepko \& Schultze-Motel, Mensch, Kultur und Umwelt im zentralen Bergland vonWest-Neuguinea 7: 13. 1981; Mizutani (1986: 290); Thiers \& Gradstein (1989: 50); Gradstein et al. (2002: 50).-Type: IndONESIA. West Irian, Jayawijaya Prov.: Eipomek-Tal, Hiepko \& Schultze-Motel 2266 (holotype: B; isotypes: JE, U).

Description. Mem. New York Bot. Gard. 52: 50-51, 53 (1989).

Illustrations. Mizutani (1986, p. 291, Fig. 5); Thiers \& Gradstein (1989, p. 52, Fig. 19); Gradstein et al. (2002, p. 50, Fig. 30).

Distribution. Eastern Malesia (Philippines, Moluccas, New Guinea).

29. Thysananthus virens Ångstr.

Mastigolejeunea virens (Ångstr.) Steph., Sp. Hepat. 4: 776. 1912; Mizutani (1986: 287); Thiers \& Gradstein (1989: 53); Gradstein et al. (2002: 52). Thysananthus virens Ångstr., Öfvers. Förh. Kongl. Svenska. Vetensk.-Akad. 5: 131. 1873. Lejeunea virens (Ångstr.) Steph., in Bescherelle, J. Bot (Monot) 12: 141. 1898.— Type: SocIETY IsLANDS. Moorea, Andersson s.n. (holotype: G; isotype: FH).

Description. Mem. New York Bot. Gard. 52: 53, 55 (1989).

Illustrations. Mizutani (1986, p. 288, Fig. 4); Thiers \& Gradstein (1989, p. 54, Fig. 20); Gradstein et al. (2002, p. 53, Fig. 32).

Distribution. Sri Lanka, Malesia, Australia Pacific.

\section{EXCLUDED TAXA}


Thysananthus africanus Steph., in Engler, Bot. Jahrb. 8: 93. 1887.-Type: EQUATORIAL GuINEA. Bioko ["Fernando Po Island”]: “Mönkemeyer 545” (holotype: G!) = Caudalejeunea africana (Steph.) Steph., Hedwigia 34: 233. 1895.

Thysananthus brasiliensis S. Arnell, in Schiffner \& S. Arnell, Österr. Akad. Wiss., Math.Naturwiss. Kl., Denkschr. 111: 118. 1964._-Type: BRAZIL. "São Paulo: prope Salto Grande do Rio Paranapanema, ca. 500 m, ..Hb. W", Schiffner 2199 (holotype: W) = Caudalelejeunea lehmanniana (Gottsche) A. Evans, Bull. Torrey Bot. Club 34: 554. 1907, syn. fide Gradstein (1994): 121.

Thysananthus crispatus Steph., Sp. Hepat. 6: 567. 1924.-Type: NEW GuINEA. "Ledermann s.n.” (holotype: G); Icon. Steph. nr. 10175 = Spruceanthus polymorphus (Sande Lac.) Verd., Ann. Bryo., Suppl. 4: 155. 1934, syn. fide Verdoorn (1934): 155.

Thysananthus elongatus (Austin) A. Evans, Trans. Connecticut Acad. Arts 10: 423. 1900. Phragmicoma elongata Austin, Proc. Acad. Nat. Sci. Philadelphia 21: 225. "1869” 1870.-Type: HAWAII. “Andersson s.n.” (holotype: G!) = Spruceanthus polymorphus (Sande Lac.) Verd., Ann. Bryol., Suppl. 4: 155. 1934, syn. fide Verdoorn (1934): 155.

Thysananthus evansii Fulford, Bull. Torrey Bot. Club 68: 34. 1941.—Type: BeLIzE. Punta Gorda: collector unknown (holotype: CINC) = Fulfordianthus evansii (Fulford) Gradst., Bryologist 95: 46. 1992.

Thysananthus fragillimus Herzog, in Handel-Mazzetti, Symb. Sin. 5: 45. 1930.-Type: CHINA. Setchwan: “... auf dem Lungdschu-schan, bei Huili, 3000 m,...”, 24 Mar 1914, Handel-Mazzettti 971 (not seen) = Spruceanthus semirepandus (Nees) Verd., Ann Bryol., Suppl. 4: 153. 1934, syn. fide Verdoorn (1934): 153.

Thysananthus lehmannianus (Nees) Steph., Sp. Hepat. 4: 785.1912. Phragmicoma lehmanniana Nees in Gottsche et al., Syn. Hepat. 302. 1845.—Type: JAMAICA. "Hb. Lehmann" (not seen) = Spruceanthus semirepandus (Nees) Verd., Ann Bryol., Suppl. 4: 153, 1934, syn. fide Geissler \& Gradstein (1994): 202. 
Thysananthus mexicanus Taylor, London J. Bot. 7: 199. 1848.-Type: EcUADOR. "on Pichincha, Feb 1847, W. Jameson s.n." (not seen) = Brachiolejeunea laxifolia (Taylor) Schiffn., in Engler \& Prantl, Nat. Pflanzenfam. 1, 3: 128. 1893, syn. fide Gradstein (1994): 172.

Thysananthus moenkemeyeri Steph., Hedwigia 34: 234. 1895, nom. nud. = Caudalejeunea africana (Steph.) Steph., Hedwigia 34: 233. 1895, syn. fide Vanden Berghen (1948): 96.

Thysananthus mutabilis Sande Lac. ex Verd., Ann. Bryol., Suppl. 4: 156. 1934, nom. inval. [Art. 34.1 (c)]. Material: ? = Spruceanthus polymorphus (Sande Lac.) Verd., Ann. Bryol., Suppl. 4: 155. 1934, syn. fide Verdoorn (1934): 155.

Thysananthus oblongifolius Chen \& Wu, Acta Phytotax. Sin. 9: 227. 1964.-Type: ChINA. Yunnan: Jing-hong, 1100 m, 29 Aug 1936, Wang 9445 (not seen) = Caudalejeunea recurvistipula (Gottsche) Schiffn., in Engler \& Prantl, Nat. Pflanzenfam. 1, 3: 129. 1893, syn. fide Zhu \& So (2001): 97.

Thysananthus obovatus B. Y. Yang, Taiwania 9: 24. 1963.-Type: TAIWAN. "Hualien Hsien, Mt. Tsing-shui, Dec 1961", T. Shimizu \& M. T. Kao 317 (not seen) = Spruceanthus semirepandus (Nees) Verd., Ann Bryol., Suppl. 4: 153. 1934, syn. fide Kitagawa (1981): 71.

Thysananthus obtusifolius Steph., Sp. Hepat. 4: 792. 1912.-Type: New CALEDONIA. (Holotype: G); Icon. Steph. nr. 10199, syn. nov. = Spruceanthus polymorphus (Sande Lac.) Verd., Ann. Bryol., Suppl. 4: 155. 1934. Verdoorn (1934) considered T. obtusifolius as a synonym of Spruceanthus. Judging from the original description and the drawing of T. obtusifolius of Stephani's "Icones Hepaticarum Ineditae", this is $S$. polymorphus.

Thysananthus olivaceus Steph. ex S. Arnell, Svensk Bot. Tidskr. 56: 349. 1962, nom. inval. [Art 32.1(d)]. Material: EcuAdoR. "Prov. Guayas: Rio Daule, below Pichincha, Hacienda Santa Barbarita (4737)" (not seen); Icon. Steph. nr. 10225: Brazil, Rio Branco, Ule 655, syn. nov. = Bryopteris filicina $($ Sw.) Nees, in Gottsche, Lindenberg \& Nees, Syn. Hepat. 284. 1845. Judging from the drawing of T. obtusifolius of 
Stephani's "Icones Hepaticarum Ineditae", which shows one leaf and one underleaf, this is B. filicina.

Thysananthus ophiocephalus Taylor, London J. Bot. 5: 384. 1846.-Type: NEw ZEALAND. "Bay of Islands", Sinclair s.n. (holotype: FH!; isotype: S!), syn. nov. = Archilejeunea olivacea (Hooker f. \& Taylor) Steph., Sp. Hepat 4: 734. 1912. Stephani (1912) considered T. ophiocephalus a synonym of Mastigolejeunea anguiformis (Hooker f. \& Taylor) B. Thiers \& Gradst. Judging from the type specimens, this is A. olivacea.

Thysananthus paucidens Steph., Sp. Hepat. 4: 793. 1912.-Type: HAWAII. (not seen); Icon. Steph. nr. 10203 = Spruceanthus polymorphus (Sande Lac.) Verd., Ann. Bryol., Suppl. 4: 155. 1934, syn. fide Verdoorn (1934): 155.

Thysananthus polymorphus (Sande Lac.) Schiffn., Consp. Hep. Archip. Ind.: 305. 1898. Phragmicoma polymorpha Sande Lac., Nat. Tijdschr. N. I. X.: 396. 1856.-Type: INDONESIA. Java: F. Junghuhn s.n. (not seen) = Spruceanthus polymorphus (Sande Lac.) Verd., Ann. Bryol., Suppl. 4: 155. 1934.

Thysananthus pterobryoides (Spruce) Schiffn., in Engler \& Prantl, Nat. Pflanzenfam. 1, 3: 130. 1893. Lejeunea pterobryoides Spruce. Trans. \& Proc. Bot. Soc. Edinburgh 15: 109. 1884.-Type: ECUADOR. “ad fluvium Pastasa, 400 m,...", Spruce s.n. (not seen) = Fulfordianthus pterobryoides (Spruce) Gradst., Bryologist 95: 44. 1992.

Thysananthus renilobus (Gottsche) Schiffn., Consp. Hep. Archip. Ind.: 306. 1898. Phragmicoma reniloba Gottsche in Gottsche, Lindenberg \& Nees, Syn. Hepat. 301. 1845.- - Type: INDONESIA. Java: "Hb. Nees" (not seen) = Caudalejeunea reniloba (Gottsche) Steph., in Gottsche et al., Syn. Hepat.: 326. 1845. Zhu \& So (2001) erroneously proposed the younger name C. recurvistipula (Gottsche) Steph. as the correct name for this species (S. R. Gradstein, pers. comm.).

Thysananthus rotundistipulus Steph., Sp. Hepat. 6: 566. 1924.-Type: INDIA. Nilgiri: Lüthi s.n. (holotype: G); Icon. Steph. nr. 10209 = Spruceanthus semirepandus (Nees) Verd., Ann. Bryol., Suppl. 4: 153. 1934, syn. fide Verdoorn (1934): 153. 
Thysananthus schiffneri S. Arnell, in Schiffner \& S. Arnell, Österr. Akad. Wiss., Math.Naturwiss. Kl., Denkschr. 111: 119. 1964.—Type: BRAZIL. "Paraná: ... ad cataractas Salto Grande, ...ca. 500 m”, Schiffner 2097 (not seen) = Acanthocoleus aberrans (Lindenb. \& Gottsche) Kruijt var. laevis Gradst., Fl. Neotrop. 62: 193. 1994, syn. fide Gradstein (1994): 193.

Thysananthus scutellatus Taylor, London J. Bot. 5: 383. 1846.—Type: NEw ZEALAND. "Mr. H. Watson's Herb.”, A. Cunningham s.n. (not seen) = Archilejeunea olivacea (Hook. \& Taylor) Steph., Bot. Jahrb. Syst. 23: 314. 1886, syn. fide Gradstein \& Buskes (1985): 101.

Thysananthus semirepandus (Nees) Schiffn., Österr. Bot. Z. 49: 205. 1899. Jungermannia semirepanda Nees, Enum. Pl. Crypt. Jav. 39. 1830.-Type: InDONESIA. Java: (not seen) $=$ Spruceanthus semirepandus (Nees) Verd., Ann. Bryol. 4, Suppl.: 153, 1934.

\section{FURTHER NAMES IN THYSANANTHUS}

Thysananthus africanus (Sim) S. Arnell, Bot. Not.: 282. 1953, nom. illeg. [Art. 53.1] Thysanolejeunea africana Sim, Trans. Roy. Soc. South Africa 15: 50. 1926.-Type: South Africa. "Perie forest, Kaffraria", Sim 346 (not seen). Wigginton \& Grolle (1996) mentioned: "To be clarified. Collected only once?".

Thysananthus erosus Steph., Sp. Hepat. 6: 568. 1924.-Type: NEw GuINEA. "Ledermann s.n.” (not seen); Icon. Steph. nr. 10180 = Conoscyphus Mitt.? Verdoorn (1934) considered T. erosus as a member of Jungermannieae. Judging from the original description and the drawing of T. erosus of Stephani's "Icones Hepaticarum Ineditae", which shows one leaf and one underleaf, this might be Conoscyphus.

Thysananthus frauenfeldii Reichardt, Verh. K. K. Zool.-Bot. Ges. Wien 16: 958. 1866. Mastigolejeunea frauenfeldii (Reichardt) Verd., Blumea 1: 230. 1934.-Type: TAHITI. Novara Exped., “...um Papiete, Jelineck s.n.” (not seen). 
Thysananthus fruticosus fo. pendula Herzog, Trans. Brit. Bryol. Soc. 1: 319.1950, nom. inval. [Art 32.1(d)]. Material: MalaYSIA. Sarawak: "Dulit, ... n. 2277”, 1932, P. W. Richards s.n. (not seen).

Thysananthus hebridensis Steph., in Stephani \& Watts, J. \& Proc. Roy. Soc. New South Wales 48: 134. 1914, nom. inval. [Art 32.1(d)]. Material: VANUATU ["New Hebrides"]. Tafea: Aneityum, Gunn s.n. (not seen).

Thysananthus integerrimus Steph., Sp. Hepat. 6: 567. 1924.-Type: NEW GuINEA. “Ledermann s.n." (not seen); Icon. Steph. nr. 10187. Verdoorn (1934) considered T. integerrimus as a member of Jungermannieae.

Thysananthus lacerostipulus Steph., Sp. Hepat. 6: 567. 1924.-Type: NEW GuINEA. Ledermann s.n. (not seen); Icon. Steph. nr. 10223 = Conoscyphus Mitt. ? Verdoorn (1934) considered T. lacerostipulus as a member of Jungermanieae. Judging from the original description and the drawing of T. lacerostipulus of Stephani's "Icones Hepaticarum Ineditae", which shows one leaf and one underleaf, this might be Conoscyphus.

Thysananthus polymorphus var. $\beta$ planifolia (Sande Lac.) Schiffn., Consp. Hep. Archip. Ind.: 305. 1898. Phragmicoma polymorphua fo. $\beta$ planifolia Sande Lac., Syn. Hepat. Jav.: 58. 1856.-Type: INDONESIA. Java: “ad montem Salak, Zollinger, coll. sub 3560 (pl. femina); Herb. v. d. Bosch (pl. mascula)" (not seen).

Thysananthus sikkimensis Steph ex Schiffn., Österr. Bot. Z. 49: 205. 1899, nom. inval. [Art 32.1(d)]. Material: BHUTAN. "between Maria Basti \& Labar, 5000-6000 ft.", 12 Apr 1898, R. L. Durel 159 (not seen).

Thysananthus ungulatus (Mitt.) Steph., Sp. Hepat. 6: 567. 1924. Lejeunea ungulata Mitt., J. Proc. Linn. Soc., Bot. 5: 110. 1861.-Type: BuRMA. "in Pegu, ad Rangoon,...", McClelland s.n. (not seen) = Spruceanthus Verd.? Verdoorn (1934) doubtfully referred T. ungulatus to Spruceanthus ("cf. sub Spruceanthus"). Judging from the original description, this might indeed be Spruceanthus. 
Thysananthus wardianus (Mitt.) Verd. (“Steph.”), Ann Bryol., Suppl. 4: 166. 1934 as in Index Hepaticarum (Geissler \& Bischler, 1990). Lejeunea wardiana Mitt., J. Proc. Linn. Soc., Bot. 5: 109. 1861.-Type: INDIA. "in Assam superiore”, Griffith s.n. (not seen) = Thysananthus subg. Mastigolejeunea (Spruce) comb. nov., syn. fide Verdoorn (1934): 166.

Thysananthus yokogurensis (Steph.) S. Hatt., J. Hattori Bot. Lab. 8: 32, 1952, nom. inval. [Art 32.1(d)]. Thysanolejeunea yokogurensis Steph. ex Yoshinaga, Bot. Mag. (Tokyo) 15: 93. 1901, nom. inval. [Art 32.1(d)]. Material: JAPAN. (not seen).

\section{ACKNOWLEDGEMENTS}

The research was supported by a Royal Thai government scholarship in cooperation with the German Academic Exchange Service (DAAD). This research also received support from the SYNTHESYS Project (http://www.synthesys.info/) financed by the European Community Research Infrastructure Action under the FP7 "Capacities" Program. I am deeply grateful to Prof. S. R. Gradstein for his contribution to the manuscript text and useful comments and suggestions on the manuscript. I would like to thank J. Wang for providing useful information. I express my gratitude to the curators of the following herbaria for making the specimens available and the loan of specimens: BCU, BKF, BM, BM-K, BR, BZ, C, FH, G, GOET, H, HIRO, JE, L, LAE, NICH, NSW, NY, PC, PSU, S, SING, STR, U and W. Thanks are also due to C. Gehrig-Downie and S. Chantanaorrapint for additional fresh materials, and to B. Raufeisen for the base map of the world.

\section{LITERATURE CITED}

Bischler, H. 1964. Recherches sur l'anatomie de la tige chez les Lejeuneaceae, II. Les sousfamilies Lejeuneoideae tribu Ptychantheae, Niponolejeuneoideae, and Myriocoleoideae. Rev. Bryol. Lichénol. 33: 399-458.

Crandall, B. 1969. Morphology and development of branches in the leafy Hepaticae. Beih. Nova Hedwigia 30: 1-261.

Fritsch, R. 1991. Index to bryophyte chromosome counts. Bryophyt. Biblioth. 40: 1-352. 
Fulford, M. H. 1941. Studies on American Hepaticae I. Revision of the genus Thysananthus. Bull. Torrey Bot. Club 68: 32-42.

Gradstein, S. R. 1975. A taxonomic monograph of the genus Acrolejeunea (Hepaticae) with an arrangement of the genera of Ptychanthoideae. Bryophyt. Biblioth. 4: 1-162.

- 1985. A guide to the Holostipous Lejeuneae. In Contributions to a monograph of the Lejeuneaceae subfamily Ptychanthoideae, ed. S. R. Gradstein, Beih. Nova Hedwigia 80: 13-29.

-. 1992a. The genera Thysananthus, Dendrolejeunea, and Fulfordianthus gen. nov. (Studies on Lejeuneaceae Subfamily Ptychanthoideae XXI). Bryologist 95: 42-51. . 1992b. Threatened bryophytes of the neotropical rain forest: a status report. Trop. Bryol. 6: 83-93.

- 1994. Lejeuneaceae: Ptychantheae, Brachiolejeuneae. Fl. Neotrop. 62: 1-216.

Gradstein, S. R., R. Matsuda, and Y. Asakawa. 1985. A chemotaxonomic survey of terpenoids and aromatic compounds in the Lejeuneaceae (Hepaticae). In Contributions to a monograph of the Lejeuneaceae subfamily Ptychanthoideae, ed. S. R. Gradstein, Beih. Nova Hedwigia 80: 63-86.

Gradstein, S. R., D. Giffini, M. I. Morales, and N. M. Nadkarni. 2001. Diversity and habitat differentiation of mosses and liverworts in the cloud forest of Monteverde, Costa Rica. Caldasia 23: 203-212.

Gradstein, S. R., X.-L. He, S. Piippo, and M. Mizutani. 2002. Bryophyte flora of the Huon Peninsula, Papua New Guinea. LXVIII. Lejeuneaceae subfamily Pychanthoideae (Hepaticae). Acta Bot. Fenn. 174: 1-88.

Gradstein, S. R., M. E. Reiner-Drehwald, and H. Schneider. 2003. A phylogenetic analysis of the genera of Lejeuneaceae (Hepaticae). Bot. J. Linn. Soc. 143: 391-410.

Gradstein, S. R., and S. G. Sporn. 2010. Land-use change and epiphytic bryophyte diversity in the Tropics. Beih. Nova Hedwigia 138: 311-323.

Grolle, R., and S. Piippo. 1984. Annotated catalogue of Western Melanesian bryophytes. I Hepaticae and Anthocerotae. Acta Bot. Fenn. 125: 1-86.

Hallingbäck, T., and N. Hodgetts. 2000. Mosses, liverworts, and hornworts. Status survey and conservation action plan for Bryophytes. IUCN/SSC Bryophyte Specialist Group. IUCN, Gland, Switzerland and Cambridge, UK. x + 106pp.

Harinantenaina, L., Y. Takahara, T. Nishizawa, C. Kohchi, G.-I. Soma, and Y. Asakawa. 2006. Chemical constituents of Malagasy liverwort, part V: prenyl bibenzyls and clerodane diterpenoids with nitric oxide inhibitory activity from Radula appressa and Thysananthus spathulistipus. Chem. Pharm. Bull. 54: 1046-1049. 
Hattori, S. 1944. Contributio ad Floram Hepaticarum Austro-Kiushiuensem. Bull. Tokyo Sci. Mus. 11: 1-203.

Heinrichs, J., J. Hentschel, K. Feldberg, A. Bombosch, and H. Schneider. 2009. Phylogenetic biogeography and taxonomy of disjunctly distributed bryophytes. J. Syst. Evol. 47: 497-508.

Herzog, T. 1931. Hepaticae Philippinenses A CL. C. J. Baker Lactae. Ann. Bryol. 4: 79-94.

Horikawa, Y. 1934. Monographia Hepaticarum Australi-Japonicarum. J. Sci. Hiroshima Univ., Ser. B, Div. 2, Bot. 2: 228-290.

Hürlimann, H. 1989. Hepaticae aus dem Gebiete des südlichen Pazifix X. Bauhinia 9: 153170.

Kruijt, R. C., G. J. Niemann, C. G. de Koster, and W. Heerma. 1986. Flavonoids and aromatic hydroxy acids in Lejeuneaceae subfamily Ptychanthoideae (Hepaticae). Cryptog. Bryol. Lichénol. 7: 165-171.

Lacouture, C. 1908. Clé analytique et synoptique des quarante et quelques sous-genres de l'ancien Lejeunea (Libert). Rev. Bryol. 35: 101-114.

Mizutani, M. 1961. A revision of Japanese Lejeuneaceae. J. Hattori Bot. Lab. 24: 115-302. 1969. Lejeuneaceae Subfamily Ptychanthoideae from Sabah (North Borneo). J. Hattori Bot. Lab. 32: 129-139.

- 1977. Lejeuneaceae from Philippines. J. Hattori Bot. Lab. 43: 127-136.

. 1986. Notes on the Lejeuneaceae. 12. Mastigolejeunea humilis and its related species from Asia. J. Hattori Bot. Lab. 61: 281-297.

- 1987. Notes on the Lejeuneaceae. 13. Some Asiatic species of the genus Thysananthus. J. Hattori Bot. Lab. 63: 411-419.

Mizutani, M., and S. Piippo. 1986. Some species of Lejeuneaceae from New Guinea. J. Hattori Bot. Lab. 61: 477-485.

Nehira, H. 1983. Spore germination, protonema development and sporeling development. In New Manual of Bryology, ed. R. M. Schuster 1: 343-385. Nichinan: The Hattori Botanical Laboratory.

Reiner-Drehwald, M. E., and A. Goda. 2000. Revision of the genus Crossotolejeunea (Lejeuneaceae, Hepaticae). J. Hattori Bot. Lab. 89: 1-54.

Schiffner, V. 1893. Hepaticae (Lebermoose). In Die Natürlichen Pflanzenfamilien, ed. A. Engler and K. Prantl, 1-141. Leipzig: Wilhelm Engelmann.

Schuster, R. M. 1966. The Hepaticae and Anthocerotae of North America, vol. 1. New York: Columbia University Press. 
1980. The Hepaticae and Anthocerotae of North America, vol. 4. New York: Columbia University Press.

Spruce, R. 1884. Hepaticae of the Amazon and of the Andes of Peru and Ecuador. III Lejeunea Libert. Trans. \& Proc. Bot. Soc. Edinburgh 15: 63-305.

Stephani, F. 1909-1912. Species Hepaticarum. IV. Genève et Bale, Lyon.

Sukkharak, P., and S. R. Gradstein. 2010a. Studies on the genus Thysananthus (Marchantiophyta: Lejeuneaceae). 1. Thysananthus discretus Sukkharak et Gradst. sp. nov. Cryptog. Bryol. 31: 113-119.

-2010b. On the occurrence of adnate underleaves and appendages in Thysananthus (Lejeuneaceae). Studies on the genus Thysananthus, 2. J. Bryol. 32: 308-310.

Sukkharak, P., A. Ludwiczuk, Y. Asakawa, and S. R. Gradstein. In press. Studies on the genus Thysananthus (Marchantiophyta, Lejeuneaceae) 3. Terpenoid chemistry and chemotaxonomy of selected species of Thysananthus and Dendrolejeunea fruticosa. Cryptog. Bryol.

Sukkharak, P., S. R. Gradstein, and M. Stech. Submitted. Phylogeny, taxon circumscriptions and chracter evolution in the core Ptychanthoideae (Lejeuneaceae, Marchantiophyta). Taxon.

Thiers, B. M. 1985. Branching in Lejeuneaceae III: Ptychanthoideae. Beih. Nova Hedwigia 80: 31-61.

Thiers, B. M., and S. R. Gradstein. 1989. Lejeuneaceae (Hepaticae) of Australia. I. Subfamily Ptychanthoideae. Mem. New York Bot. Gard. 52: 1-79.

Vanden Berghen, C. 1949. Contribution a l'étude des espèces africaines du genre Mastigolejeunea (Spruce) Schiffn. Bull. Jard. Bot. État 19: 371-382.

—. 1950. Le genre Thysananthus Lindenb. en Afrique. Rev. Bryol. Linchénol. 19: 3537.

Verdoorn, F. 1934. Studien über Asiatische Jubuleae (De Frullaniaceis XV-XVII) mit einer Einleitung, Bryologie und Hepaticologie, Ihre Methodik und Zukunft. Ann. Bryol., Suppl. 4: 1-231.

Weis, G. 2001. Morphologische un anatomische Untersuchungen der Sporophyten bei den Jubulaceae Klinggr. und Lejeuneaceae Casares-Gil (Hepaticae) und deren systematische Bedeutung. Bryophyt. Biblioth. 57: 1-307.

Wilson, R., S. R. Gradstein, H. Schneider, and J. Heinrichs. 2007a. Unravelling the phylogeny of Lejeuneaceae (Jungermanniopsida). Mol. Phylogenet. Evol. 43: 270-282. 
Wilson, R., J. Heinrichs, J. Hentschel, S. R. Gradstein, and H. Schneider. 2007b. Steady diversification of derived liverworts under Tertiary climatic fluctuations. Biol. Lett. 3: $566-569$.

Zanten, B. O. van, and S. R. Gradstein. 1988. Experimental dispersal geography of neotropical liverworts. Beih. Nova Hedwigia. 90: 41-94. 

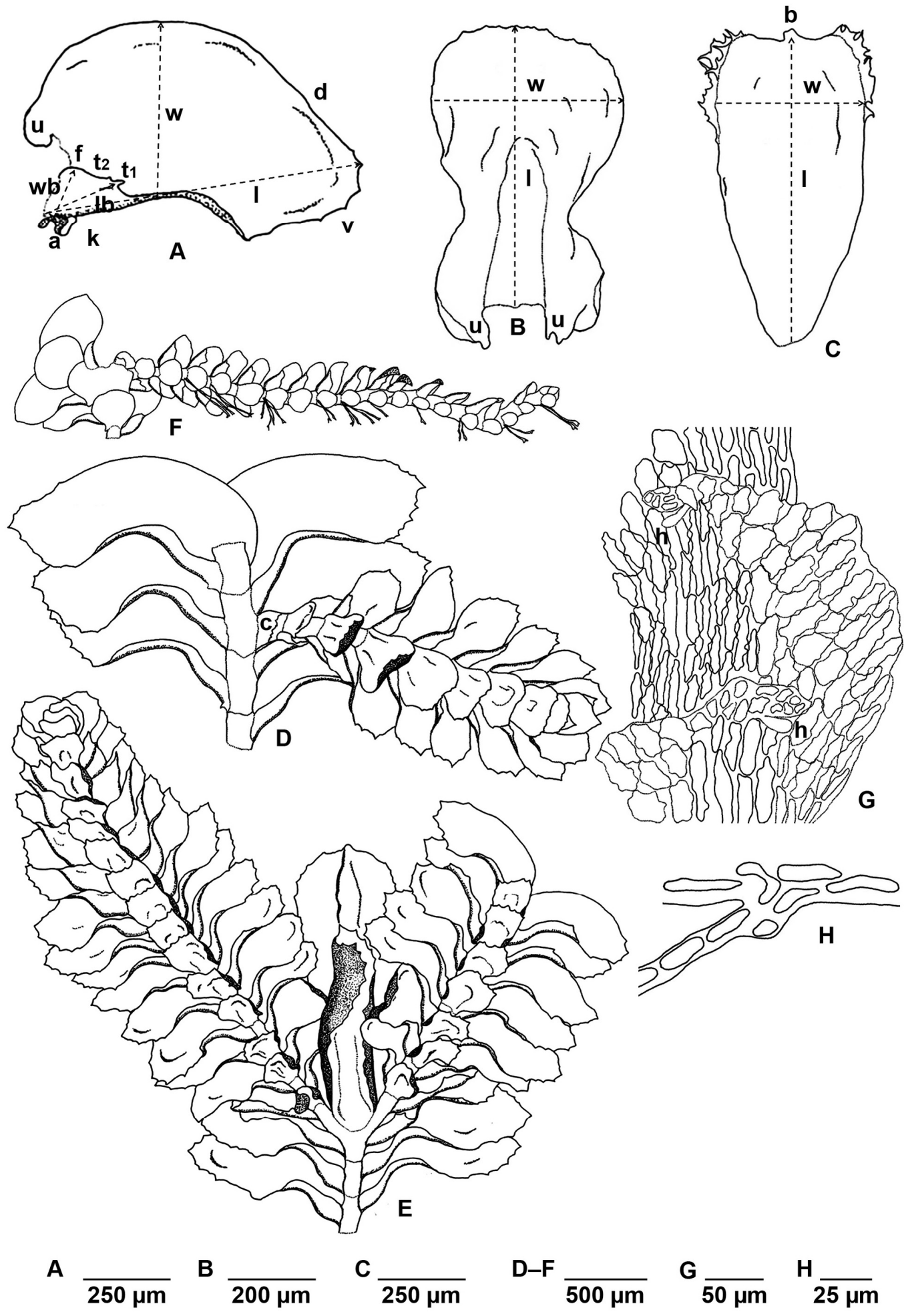

FIG. 1. Method of measurement in subg. Thysananthus. A. Leaf, ventral view: $a=$ appendage, $d=$ dorsal leaf margin, $f=$ lobule free margin, $\mathrm{k}=$ keel, $\mathrm{l}=$ leaf length, $\mathrm{lb}=$ lobule length, $\mathrm{t}_{1,2}=$ lobule teeth, $\mathrm{u}=$ auricle, $\mathrm{v}=$ ventral leaf margin, $\mathrm{w}=$ leaf width, $w b=$ lobule width. $\mathrm{B}$. Underleaf, ventral view: $\mathrm{u}=$ auricle, $\mathrm{l}=$ underleaf length, $\mathrm{w}=$ underleaf width. C. Perianth, ventral view: $\mathrm{b}=$ beak, 1 = perianth length, $\mathrm{w}=$ perianth width. D. Portion of shoot with Lejeunea-type branching, ventral view: $\mathrm{c}=$ collar. E. Portion of shoot with androecia, gynoecium and lejeuneoid innovation (dichasial pattern), ventral view. F. Flagella at stem base, ventral view. G. Lateral merophyte cells arranged in straight longitudinal line: $\mathrm{h}=$ hyaline appillae. $\mathrm{H}$. Underleaf base in longitudinal section. (A from lectotype of T. appendiculatus; B-C from holotype of T. discretus; D from T. spathulistipus, Sukkharak 766 (BKF, GOET); E from T. spathulistipus, Sukkharak 746 (BKF, GOET); F from isolectotype of T. comosus; G from T. spathulistipus, Sukkharak 761 (BKF, GOET); H from holotype of T. discretus). 

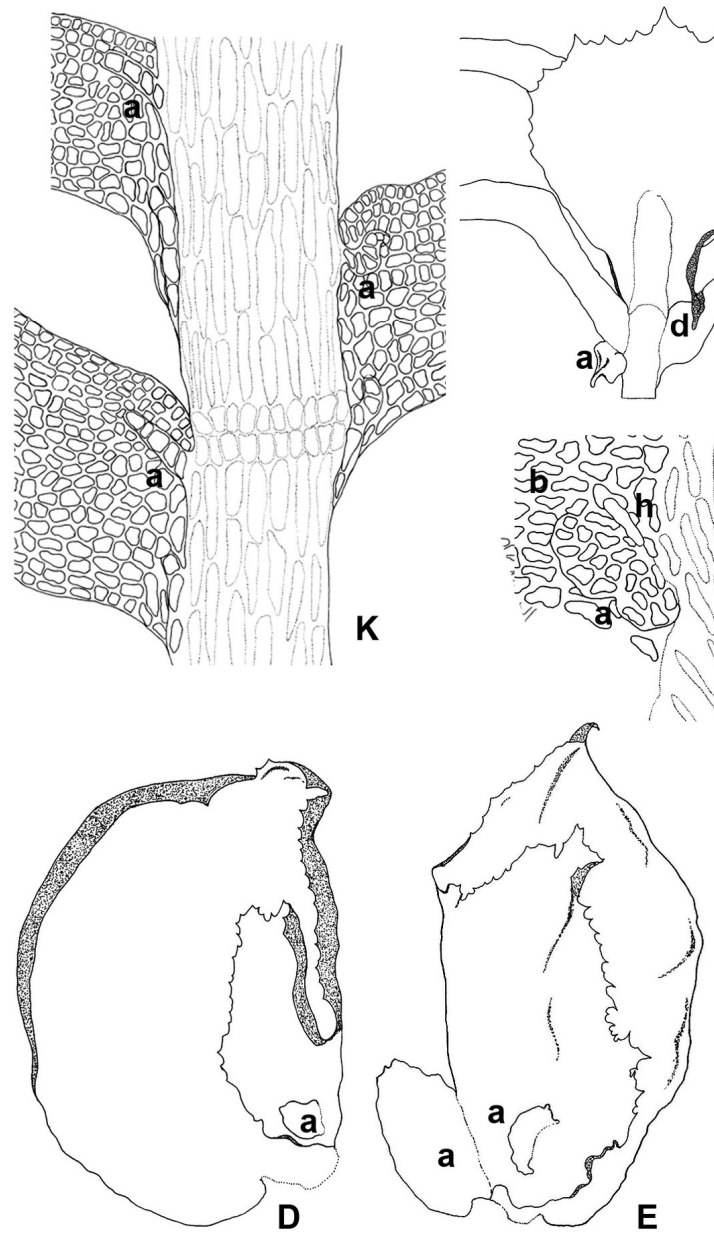

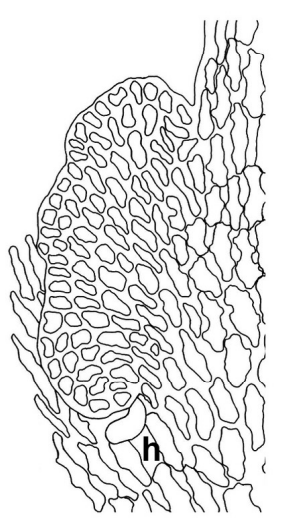

G

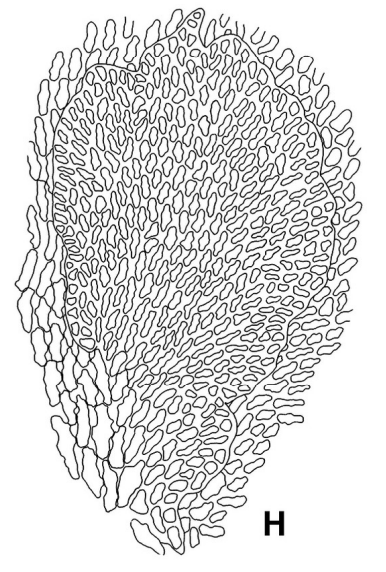

B

D-F, I

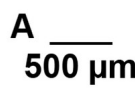
$\overline{25 \mu \mathrm{m}}$

\section{$\overline{500 \mu \mathrm{m}}$}

A
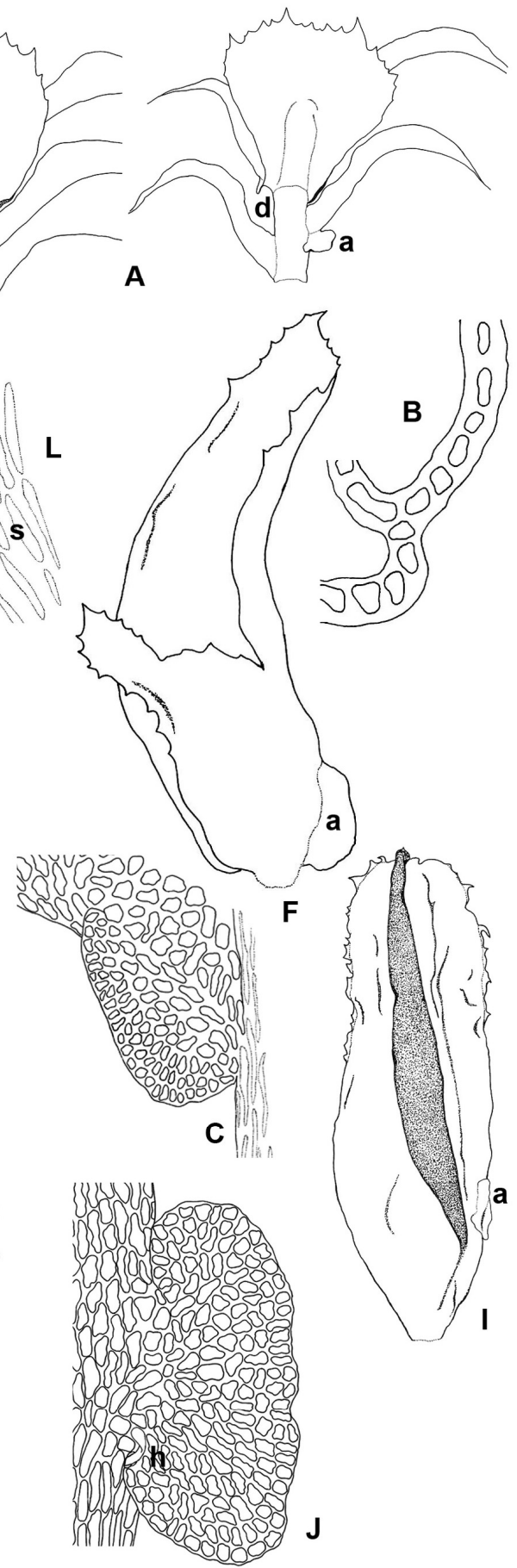

C, G-J, K-L

FIG. 2. Leaves and underleaves adnation and appendages in subg. Thysananthus. A. Portions of plant, ventral view: $d=$ adnation, $\mathrm{a}=$ appendage. B. Adnation in longitudinal section. C. Appendages at bases of leaf keels. D-F. Female bracts, ventral view: $\mathrm{a}=$ appendage. $\mathrm{G}$. Appendage and hyaline papilla at base of bract keels: $\mathrm{h}=$ hyaline papilla. $\mathrm{H}$. Appendage at mid-basal portion of bract lobule. I. Perianth, ventral view: $a=$ appendage. J. Appendage and hyaline papilla of perianth: $h=$ hyaline papilla. K. Portions of plant showing appendage at lobule base, ventral view: $a=$ appendage. L. Appendage: $b=$ lobule, $\mathrm{a}=$ appendage, $\mathrm{h}=$ hyaline papilla, $\mathrm{s}=$ stem. (A from isolectotype of $T$. comosus; B from T. spathulistipus, Sukkharak 766 (BKF, GOET); C, E, H from holotype of T. discretus; D from holotype of T. gottschei var. continuus; F from T. appendiculatus, Gradstein 3875 (U); G from T. appendiculatus, Streimann \& Tamba 12358 (JE); I-J from T. mollis, Gradstein 3795 (U); K from T. retusus subsp. retusus, Sukkharak 733 (BKF, GOET); L from T. montanus, Streimann 13639 (LAE)). 


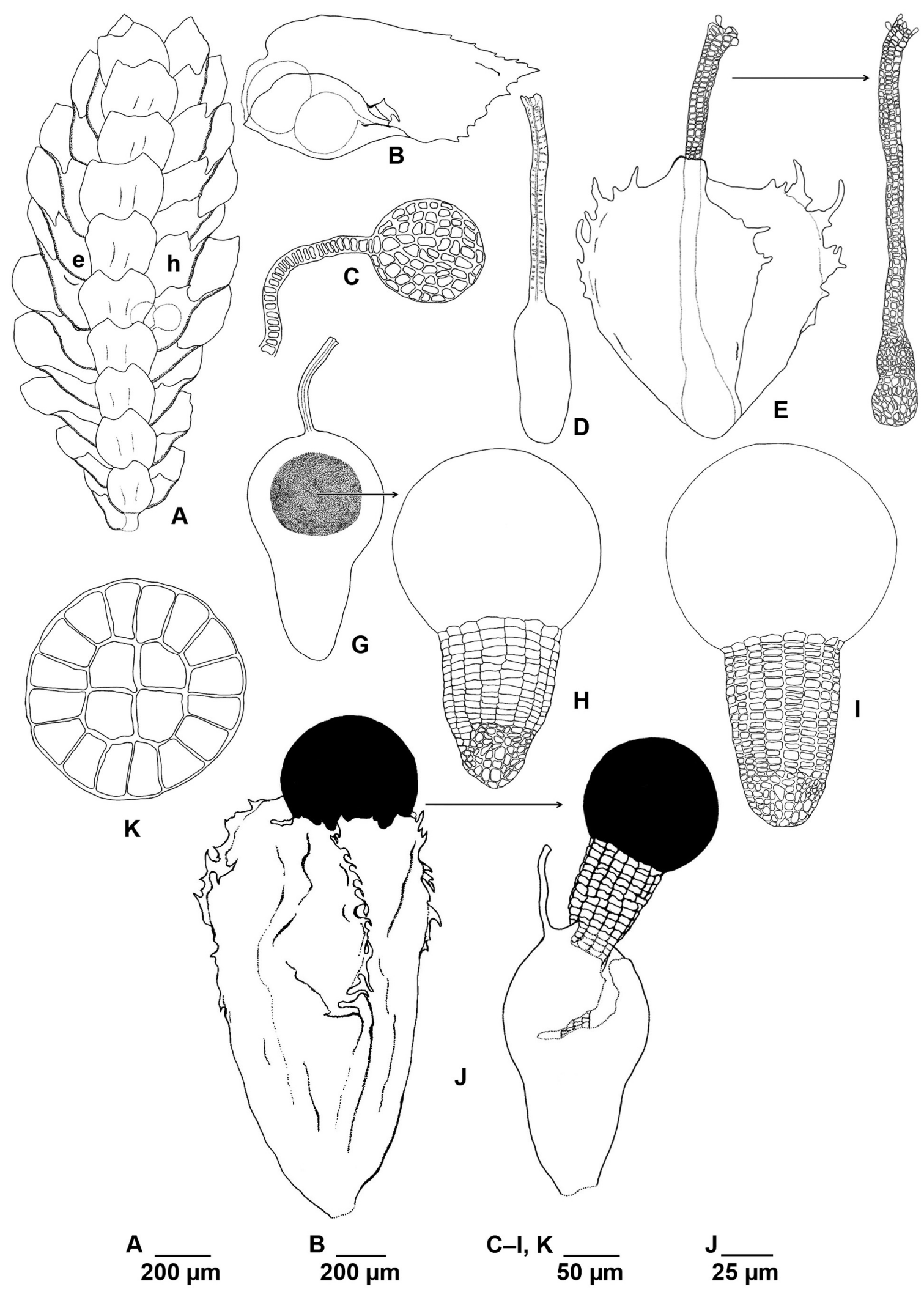

F

FIG. 3. Androecia, Gynoecia and young sporophyte in subg. Thysananthus. A. Portion of androecial spike showing epistatic and hypostatic lobules, ventral view: $\mathrm{e}=$ epistatic, $\mathrm{h}=$ hypostatic. B. Male bract with 2 antheridia. C. Antheridia. D. Juvenile perianth. E. perianth and protruding archegonial neck. F. Archegium and archgonial neck. G. Later stage of development. H. Sporophyte prior to elongation of seta. I. Sporophyte after partial elongation of seta. J. Mature perianth, just dehiscence. K. Transverse section of seta. (A from T. amazonicus, Cornelissen \& Steeger C682 (U); B from T. spathulistipus, Gradstein 3964 (U); C from T. spathulistipus, Gradstein 3965 (U); D-G from T. spathulistipus, Sukkharak 766 (BKF, GOET); H-I, K from T. retusus subsp. retusus, Streimann 40547 (JE); J from T. spathulistipus, Sipman 6992 (U)). 

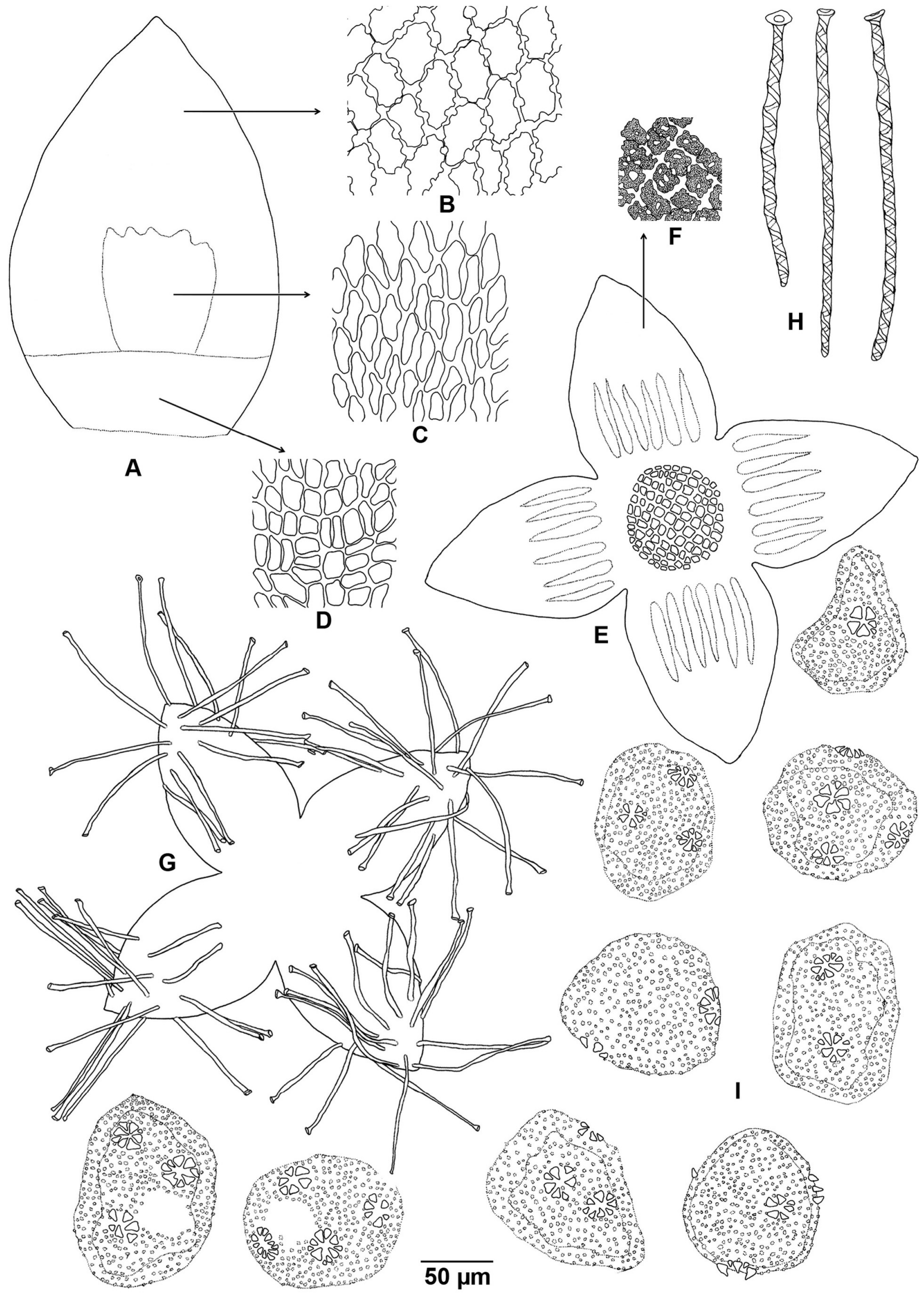

FIG. 4. Sporophyte in subg. Thysananthus. A. Outer surface of capsule valve, showing rectangular-shaped hinge. B-D. Cells of the outer layer of the capsule valve, surface view. E. Inner surface of dehiscing capsule, showing base of capsule and longitudinal ridges. F. Cells of the inner layer of the capsule valve, surface view. G. Inner surface of dehiscing capsule, showing elaters patterns of either $1+3+5+6$ or $2+4+6+6$ per valve. H. Elaters. I. Spores. (A-G from T. spathulistipus, Yong \& Ponniah 2981 (GOET); H from T. spathulistipus, Thiers \& Roy 2397 (U); I from T. spathulistipus, Sipman 6992 (U)). 
BPP, BPPSIC, MPB \& MPBSIC $\geq 95$

BPP \& BPPSIC $\geq 95$, either MPB or MPBSIC $\geq 95$

BPP \& BPPSIC $\geq 95$, MPB \& MPBSIC $>70$

BPP \& BPPSIC $\geq 95$, either MPB or MPBSIC $>70$

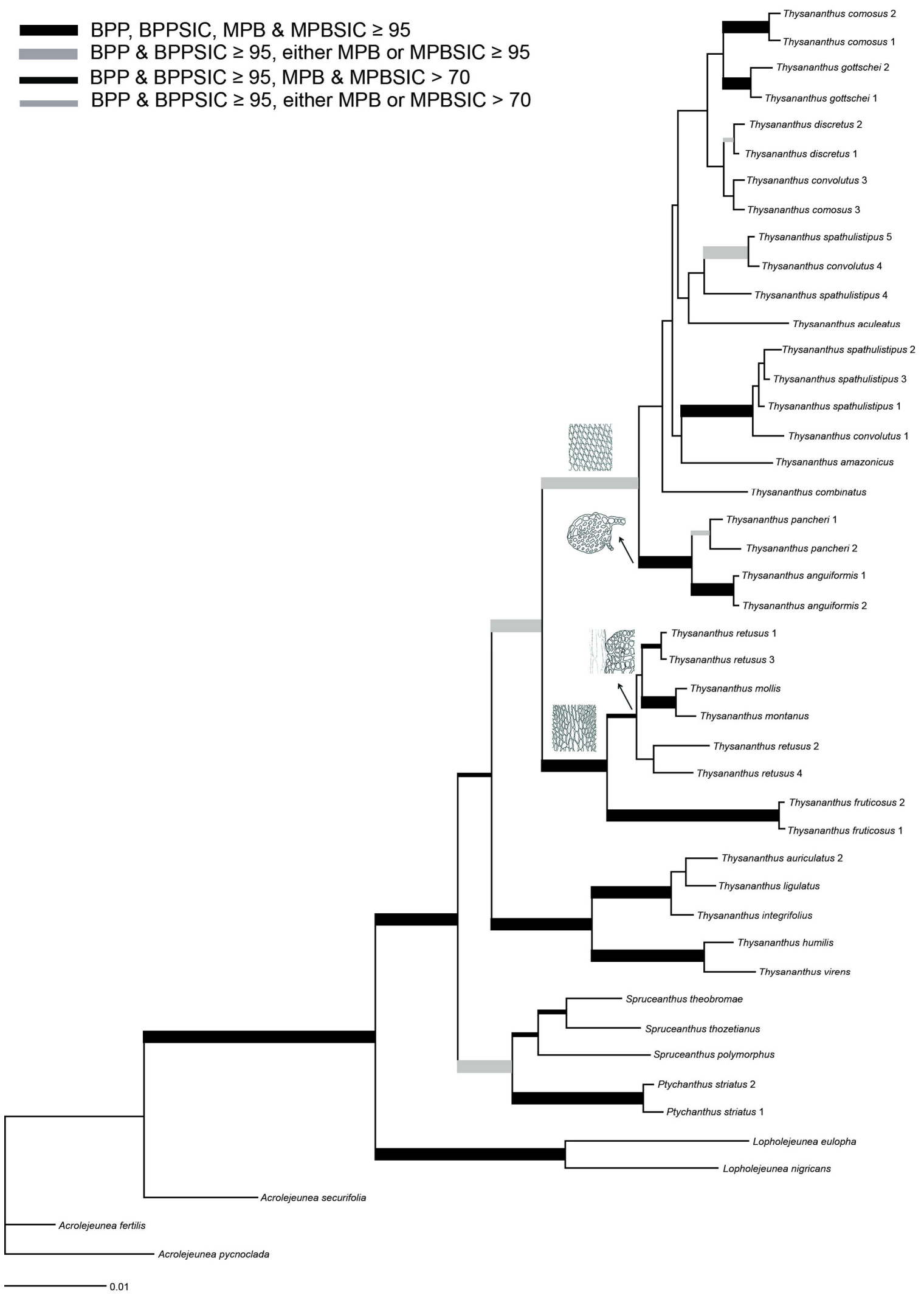

FIG. 5. Majority rule Bayesian phylogram inferred from the combined chloroplast dataset including differences in sequence lengths (indels). Branch thickness and color indicate bootstrap support and posterior probability values. BPP $=$ posterior probability values from Bayesian analysis, in which gaps treated as missing data; BPPSIC = posterior probability values from Bayesian analysis, in which gaps treated as informative by a simple indel coding strategy; MPB = bootstrap support values from the maximum parsimony optimality criterion, in which gaps treated as missing data; MPBSIC = bootstrap support values from the maximum parsimony optimality criterion, in which gaps treated as informative by a simple indel coding strategy. Modified after Sukkharak et al. (Submitted). 
Chapter VI

BPP, BPPSIC, MPB \& MPBSIC $\geq 95$

BPP \& BPPSIC $\geq 95$, either MPB or MPBSIC $\geq 95$

BPP \& BPPSIC $\geq 95$, MPB \& MPBSIC $>70$

BPP \& BPPSIC $\geq 95$, either MPB or MPBSIC $>70$

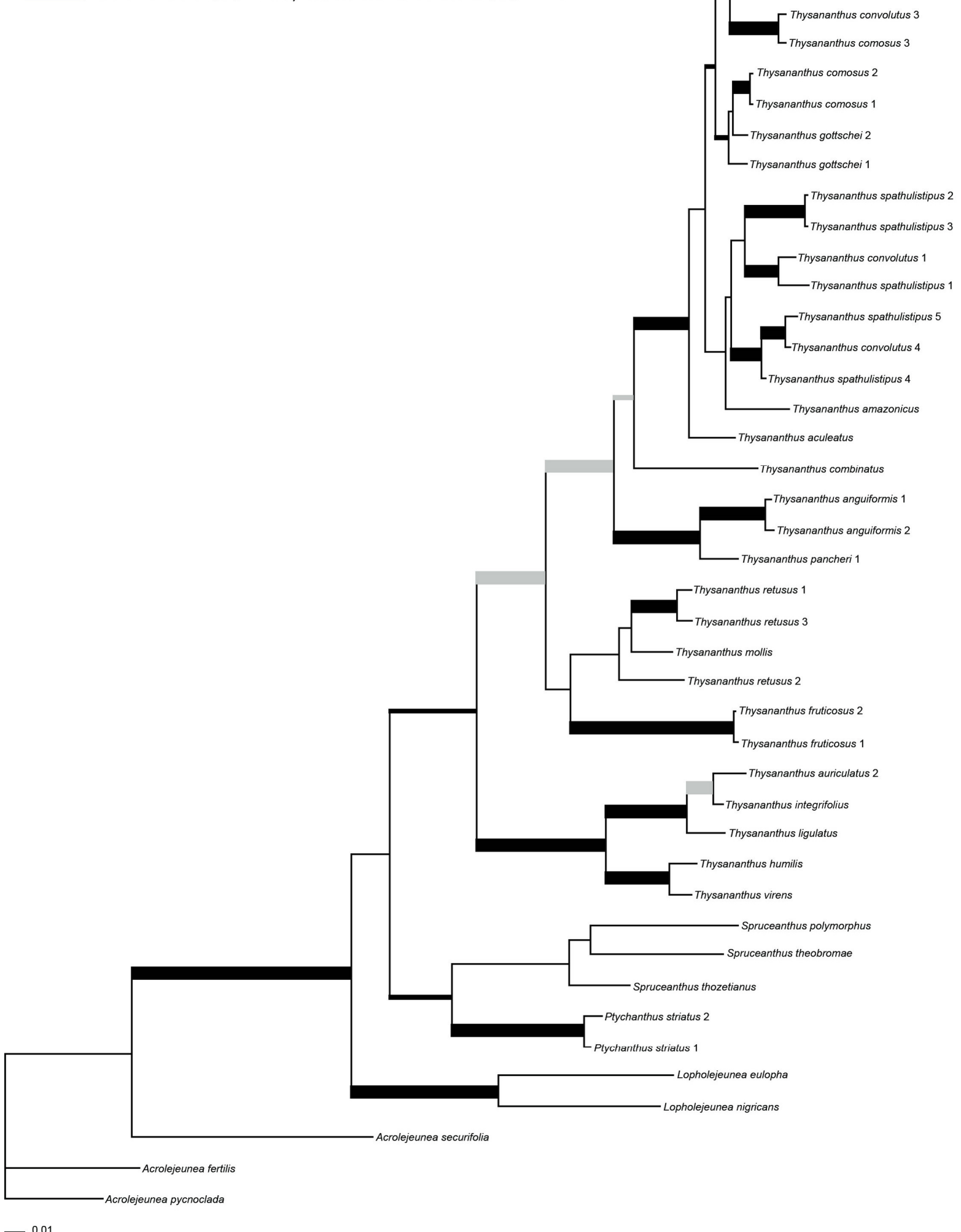

FIG. 6. Majority rule Bayesian phylogram inferred from the ITS dataset. For further explanation see Fig. 5. Modified after Sukkharak et al. (Submitted). 


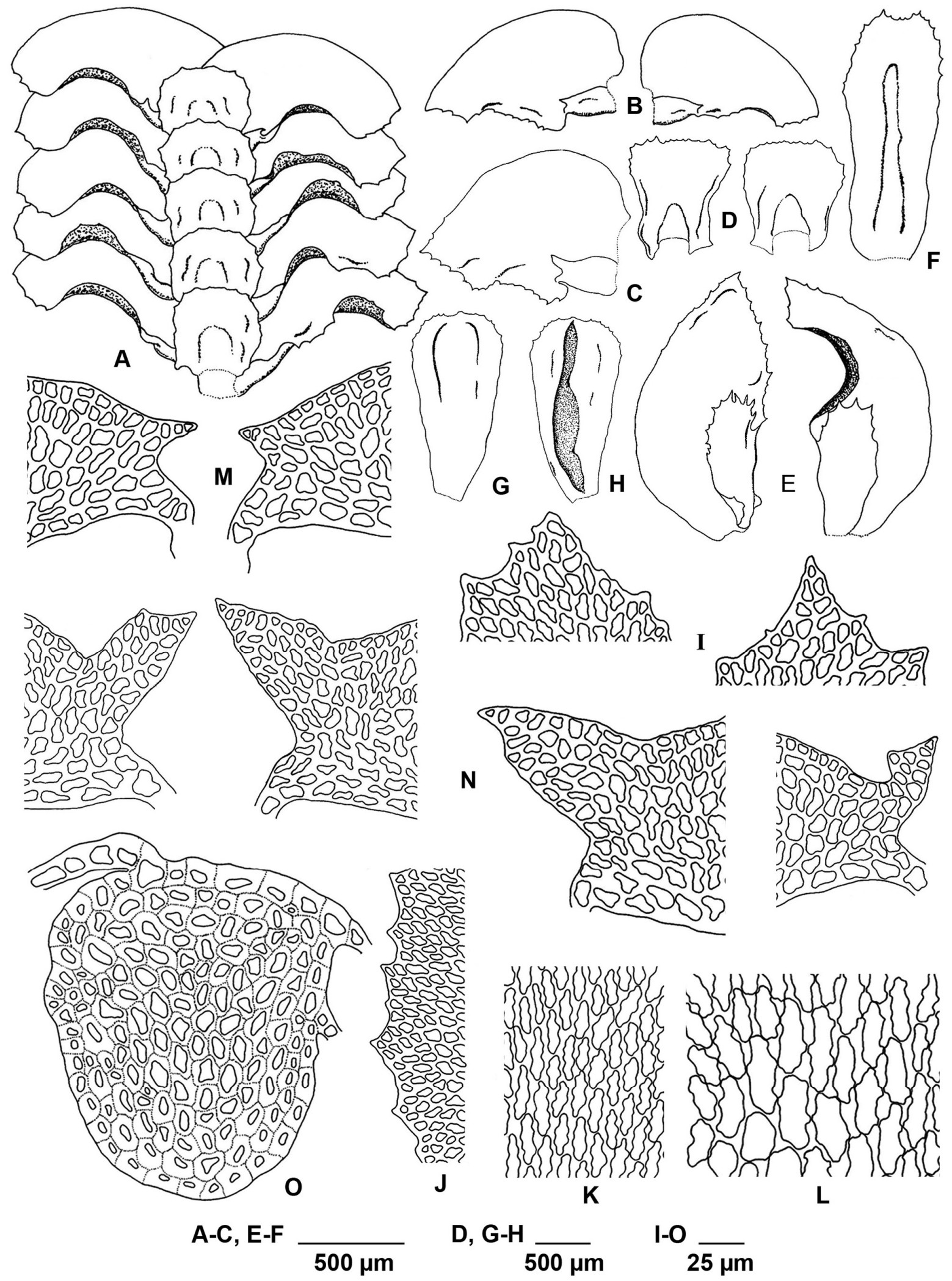

FIG. 7. Thysananthus aculeatus Herzog. A. Portion of shoot, ventral view. B-C. Leaves, ventral view. D. Underleaves, ventral view. E. Female bracts, ventral view. F. Female bracteole, ventral view. G. Perianth, dorsal view. H. Perianth, ventral view. I. Leaf apices. J. Margin cells of leaf lobe. K. Median cells of leaf lobe. L. Basal cells of leaf lobe. M-N. Leaf lobule apices. O. Cross section of stem. (A-B, D-M, O from the lectotype; C, N from paralectotype). 

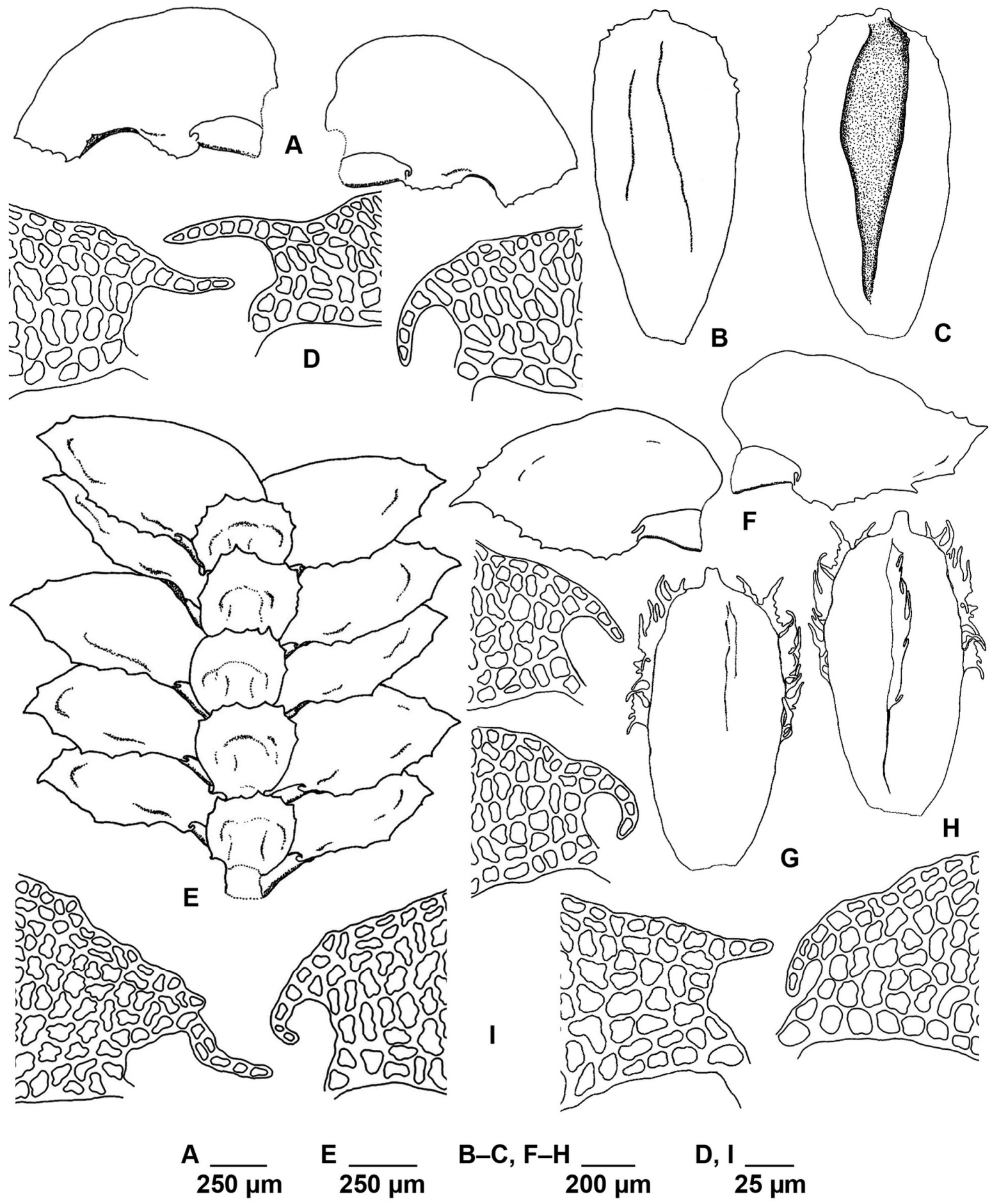

FIG. 8. Thysananthus aculeatus Herzog. A. Leaves, ventral view. B. Perianth, dorsal view. C. Perianth, ventral view. D. Leaf lobule apices. E. Portion of shoot, ventral view. F. Leaves, ventral view. G. Perianth, dorsal view. H. Perianth, ventral view. I. Leaf lobule apices. (A-D from holotype of T. formosanus; E-I from the holotype of T. richardsianus). 


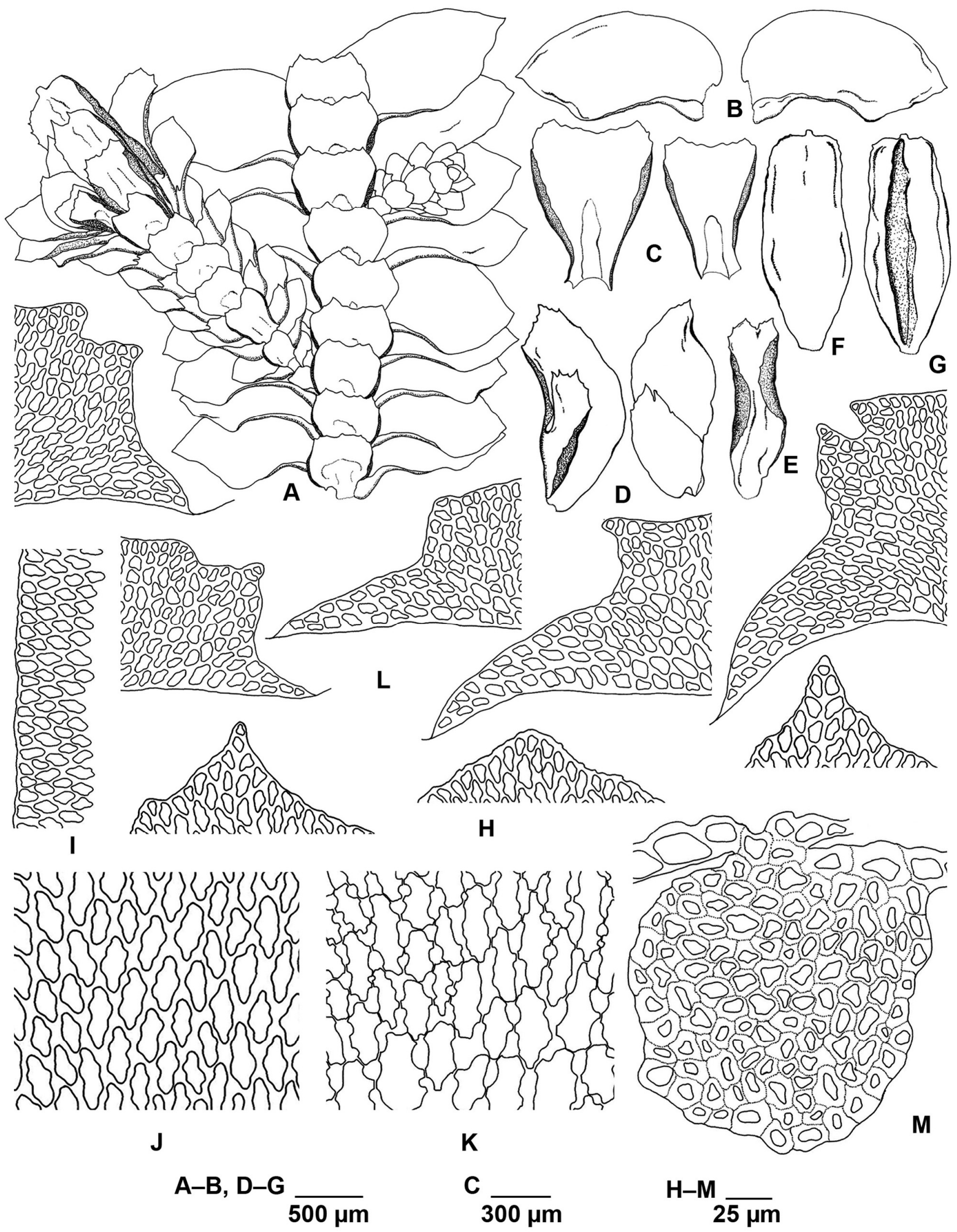

FIG. 9. Thysananthus amazonicus (Spruce) Schiffn. A. Portion of shoot, ventral view. B. Leaves, ventral view. C. Underleaves, ventral view. D. Female bracts, ventral view. E. Female bracteole, ventral view. F. Perianth, dorsal view. G. Perianth, ventral view. H. Leaf apices. I. Margin cells of leaf lobe. J. Median cells of leaf lobe. K. Basal cells of leaf lobe. L. Leaf lobule apices. M. Cross section of stem. (All from Gradstein s.n. (GOET)). 


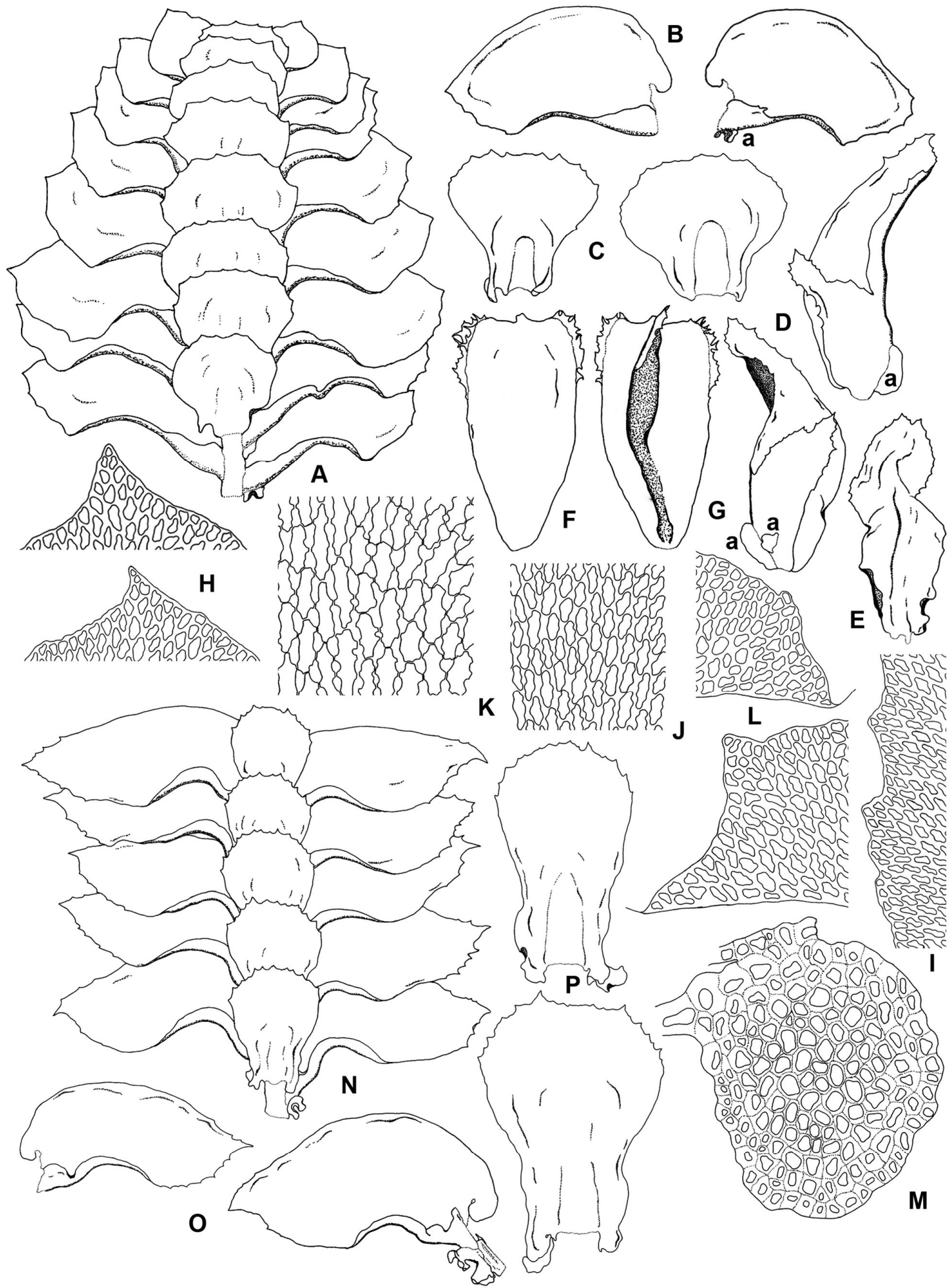

A-B

C-G, N-P

$500 \mu \mathrm{m}$ $\overline{500 \mu \mathrm{m}}$

H-M

$25 \mu \mathrm{m}$

FIG. 10. Thysananthus appendiculatus Steph. A. Portion of shoot, ventral view. B. Leaves, ventral view: a = appendage. C. Underleaves, ventral view. D. Female bracts, ventral view: a = appendage. E. Female bracteole, ventral view. F. Perianth, dorsal view. G. Perianth, ventral view. H. Leaf apices. I. Margin cells of leaf lobe. J. Median cells of leaf lobe. K. Basal cells of leaf lobe. L. Leaf lobule apices. M. Cross section of stem. N. Portion of shoot, ventral view. O. Leaves, ventral view. P. Underleaves, ventral view. (A-C, H-M from the lectotype; D-G from Streimann 13859 (JE); N-P from Gradstein 3875 $(\mathrm{GEOT}))$. 


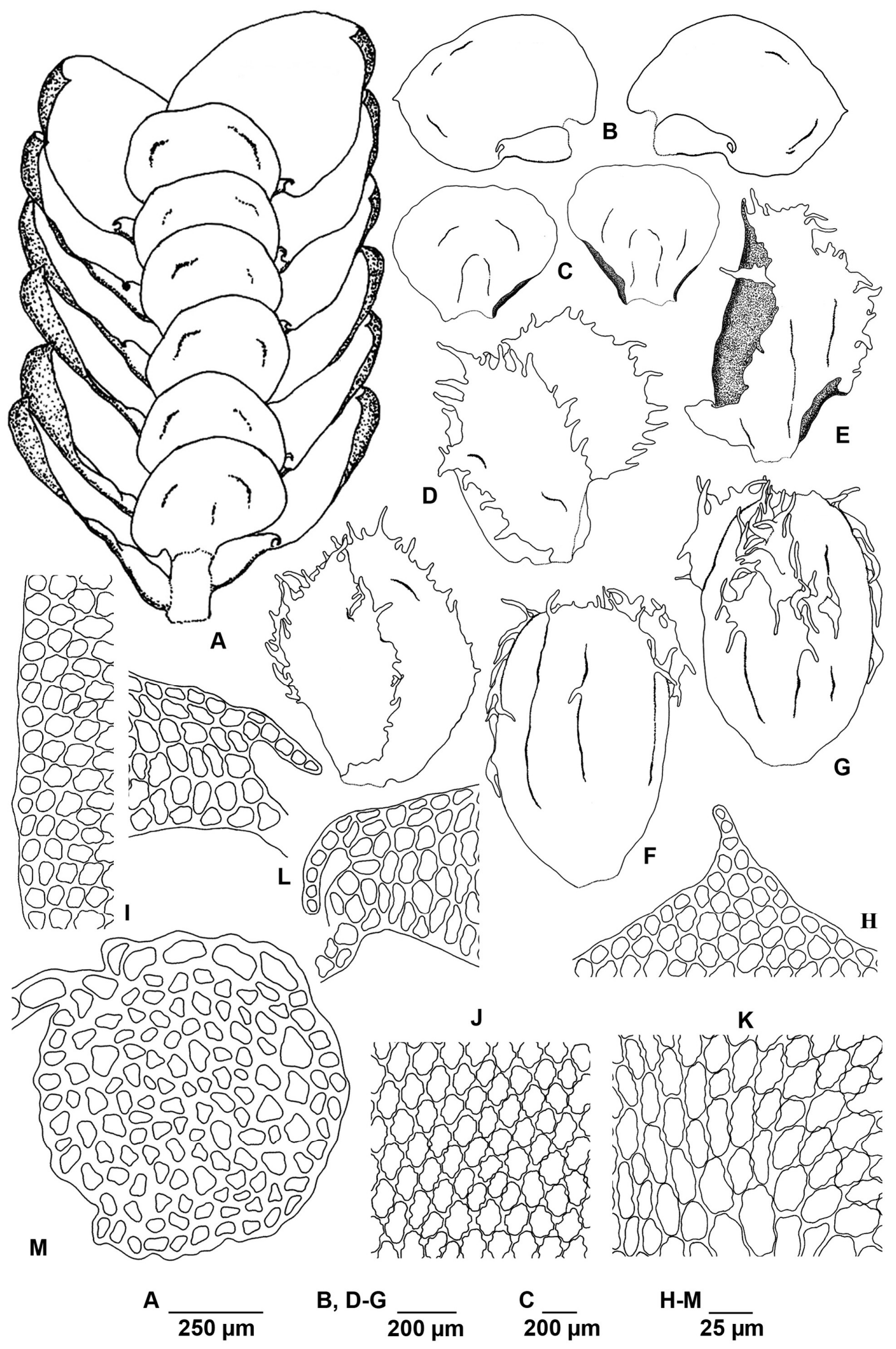

FIG. 11. Thysananthus combinatus sp. nov. A. Portion of shoot, ventral view. B. Leaves, ventral view. C. Underleaves, ventral view. D. Female bracts, ventral veiw. E. Female bracteole, ventral view. F. Perianth, dorsal view. G. Perianth, ventral view. H. Leaf apex. I. Margin cells of leaf lobe. J. Median cells of leaf lobe. K. Basal cells of leaf lobe. L. Leaf lobule apices. M. Cross section of stem. (All from the holotype). 


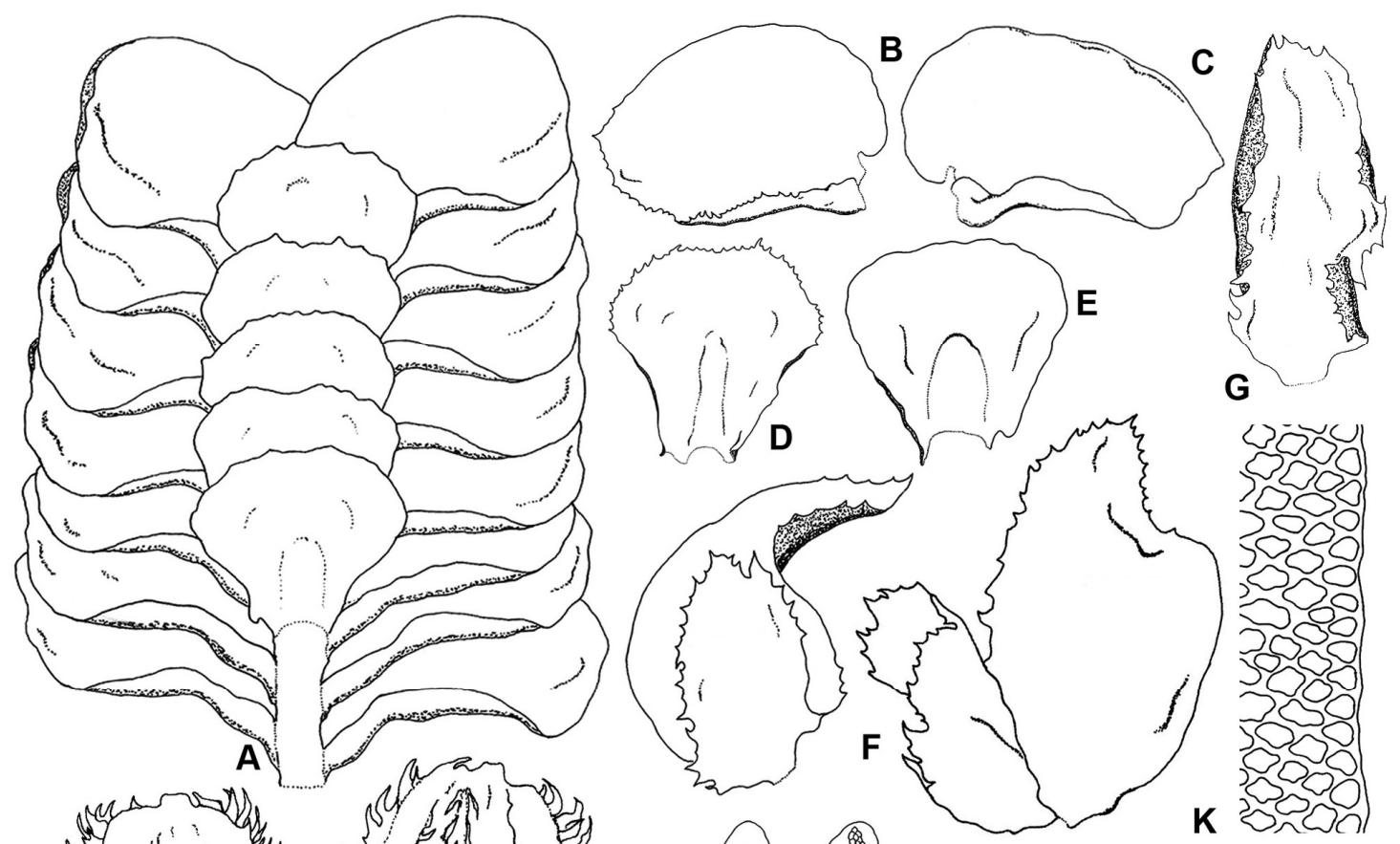

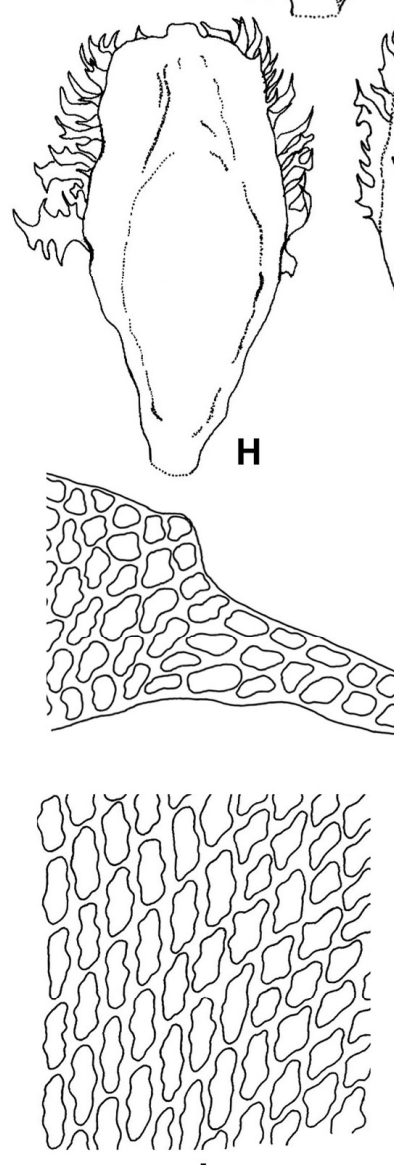

L
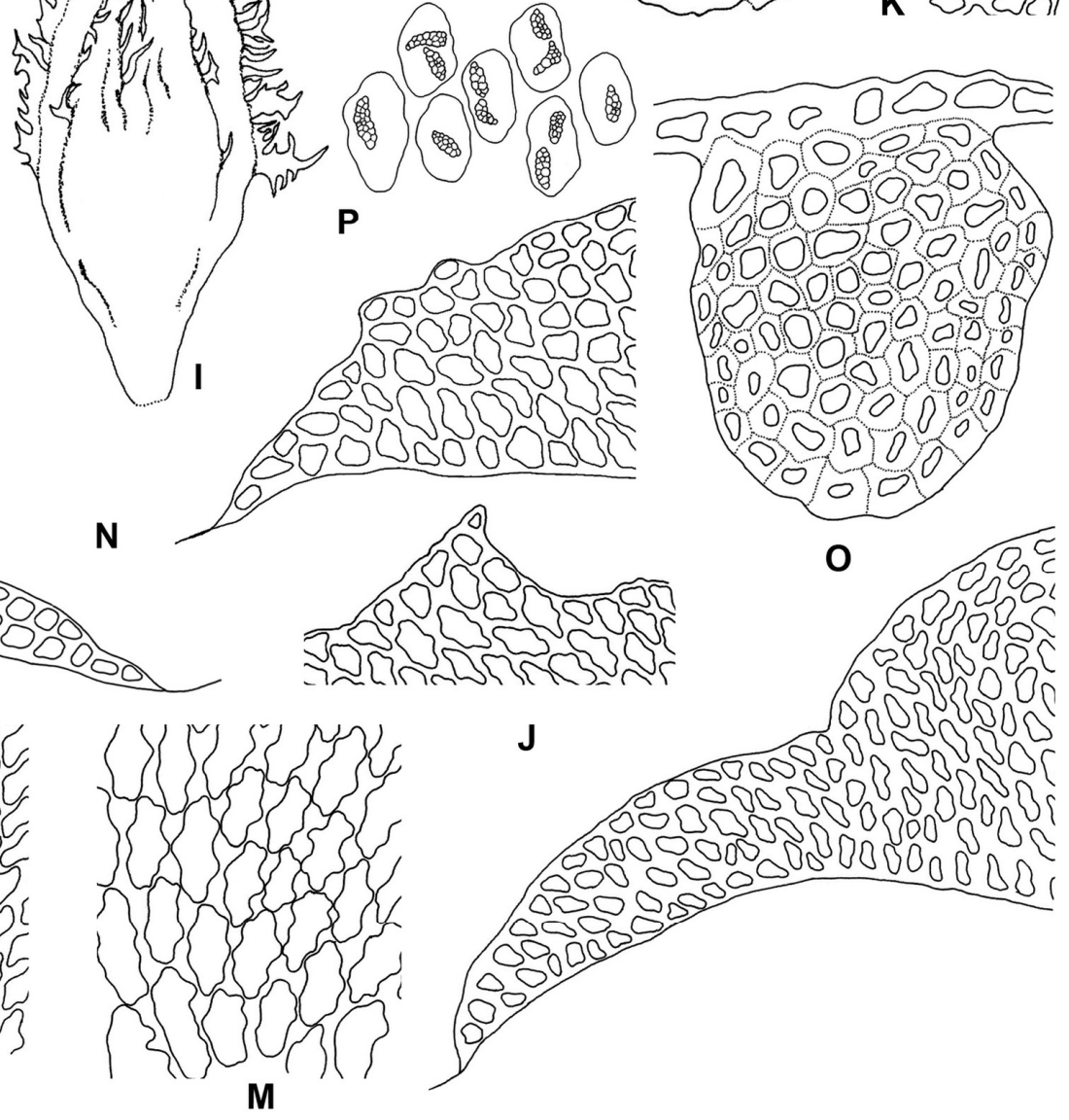

A, C, E-I

B, D

$500 \mu \mathrm{m}$

$\overline{300 \mu \mathrm{m}}$

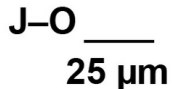

$\mathbf{P}$

$25 \mu \mathrm{m}$

FIG. 12. Thysananthus comosus Lindenb. A. Portion of shoot, ventral view. B-C. Leaves, ventral view. D-E. Underleaves, ventral view. F. Female bracts, ventral view. G. Female bracteole, ventral view. H. Perianth, dorsal view. I. Perianth, ventral view. J. Leaf apex. K. Margin cells of leaf lobe. L. Median cells of leaf lobe. M. Basal cells of leaf lobe. N. Leaf lobule apices. O. Cross section of stem. P. Oil bodies (A, C, E-O from the lectotype, B, D from Schiffner s.n. (GOET), P from Sukkharak 730 (BKF, GOET)). 


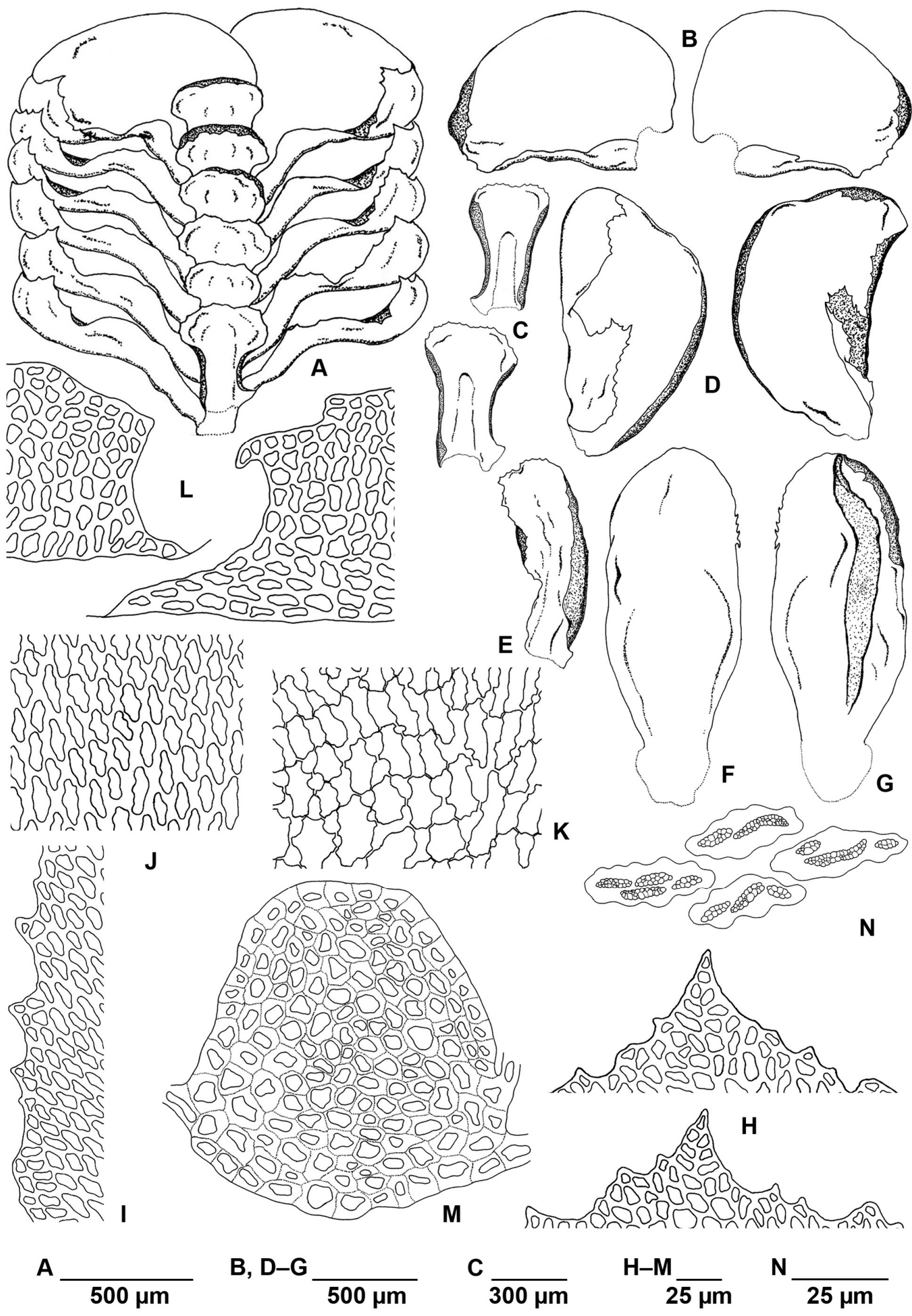

FIG. 13. Thysananthus convolutus Lindenb. A. Portion of shoot, ventral view. B. Leaves, ventral view. C. Underleaves, ventral view. D. Female bracts, ventral view. E. Female bracteole, ventral view. F. Perianth, dorsal view. G. Perianth, ventral view. H. Leaf apices. I. Margin cells of leaf lobe. J. Median cells of leaf lobe. K. Basal cells of leaf lobe. L. Leaf lobule apices. M. Cross section of stem. N. Oil bodies. (A-M from the lectotype; N from Sukkharak 717 (BKF, GOET)). 


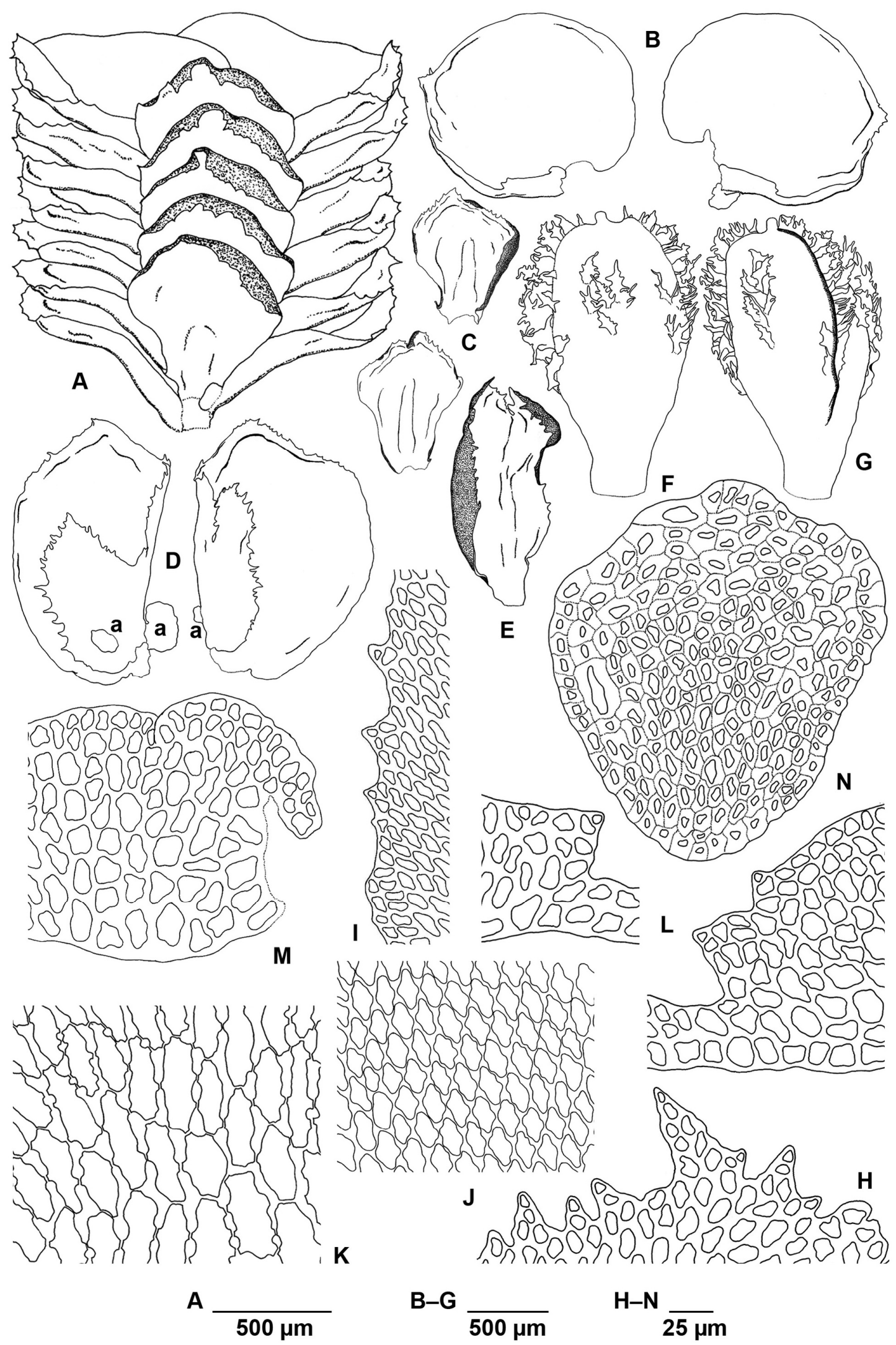

FIG. 14. Thysananthus convolutus var laceratus (Steph.) comb. nov. A. Portion of shoot, ventral view. B. Leaves, ventral view. C. Underleaves, ventral view. D. Female bracts, ventral view: a = appendage. E. Female bracteole, ventral view. F. Perianth, dorsal view. G. Perianth, ventral view. H. Leaf apex. I. Margin cells of leaf lobe. J. Median cells of leaf lobe. K. Basal cells of leaf lobe. L. Leaf lobule apices. M. Leaf lobule base. N. Cross section of stem. (All from the lectotype). 


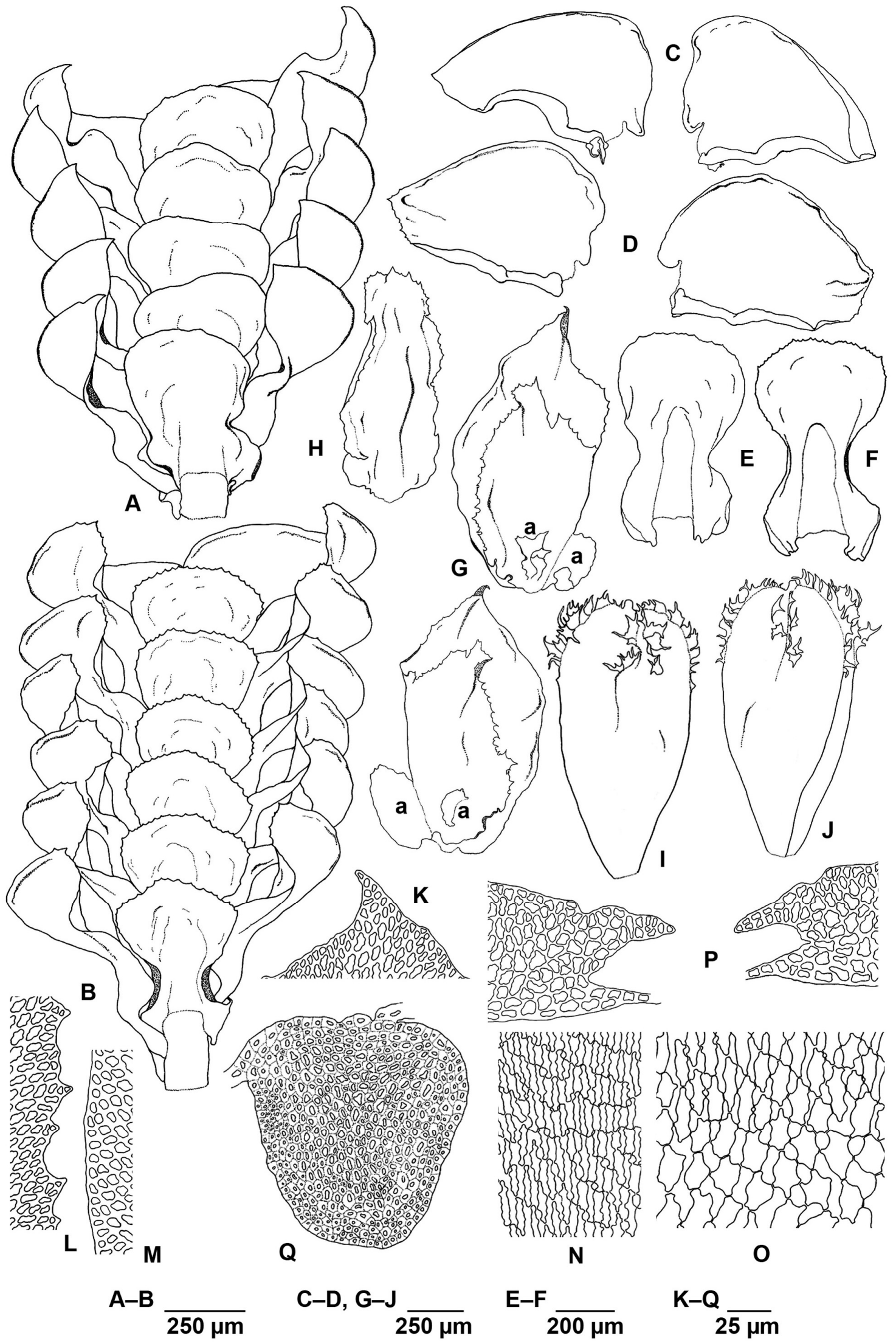

FIG. 15. Thysananthus discretus Sukkharak \& Gradst. A-B. Portion of shoot, ventral view. C-D. Leaves, ventral view. E-F. Underleaves, ventral view. G. Female bracts, ventral view: a appendage. H. Female bracteole, ventral view. I. Perianth, dorsal view. J. Perianth, ventral view. K. Leaf apex. L-M. Margin cells of leaf lobe. N. Median cells of leaf lobe. O. Basal cells of leaf lobe. P. Leaf lobule apices. Q. Cross section of stem. (A, C, E, G-K, M-Q from the holotype; B, D, F, L from Streimann $13622(\mathrm{JE}))$. 


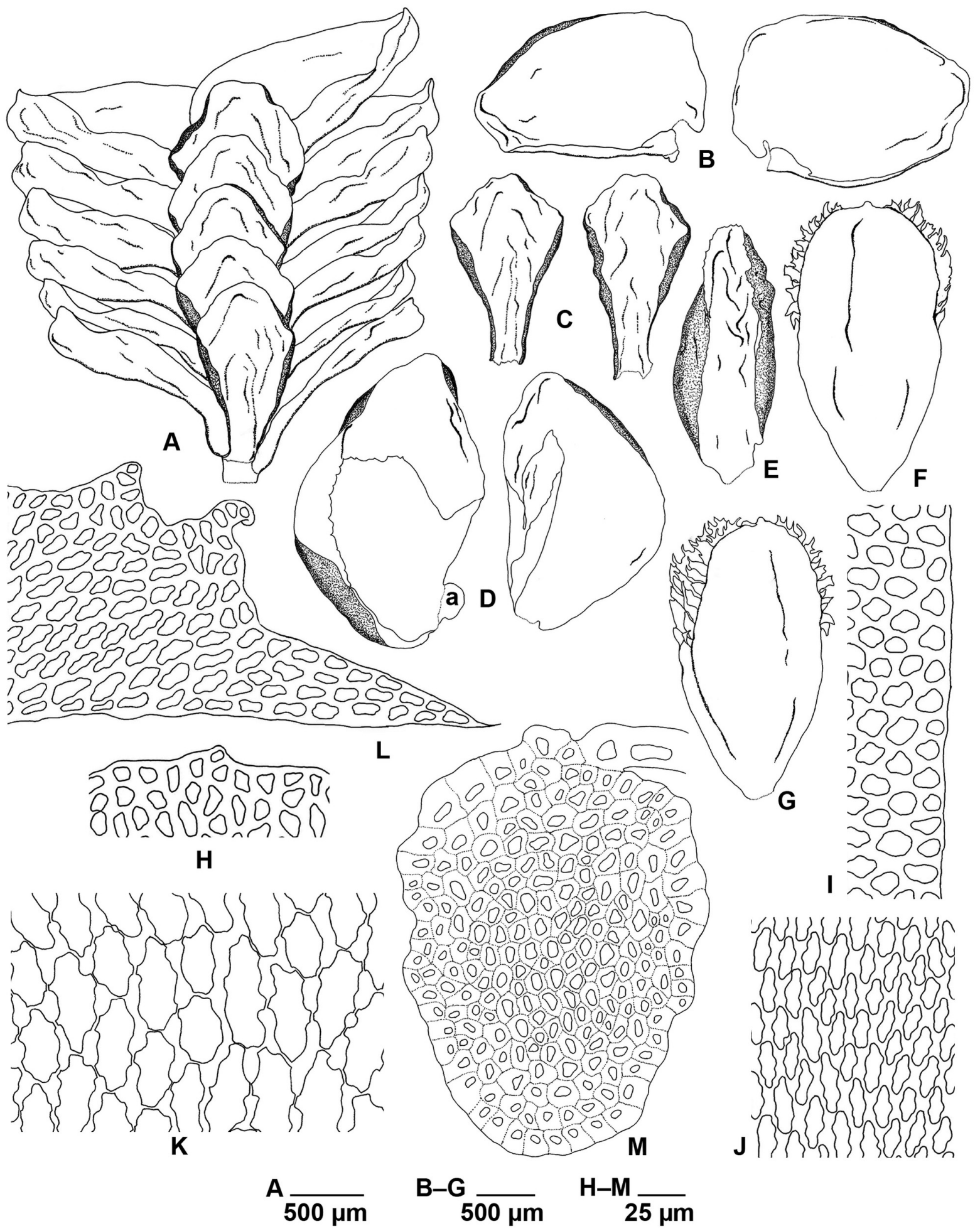

FIG. 16. Thysananthus gottschei (Jack \& Steph.) Steph. A. Portion of shoot, ventral view. B. Leaves, ventral view. C. Underleaves, ventral view. D. Female bracts, ventral view: a = appendage. E. Female bracteole, ventral view. F. Perianth, dorsal view. G. Perianth, ventral view. H. Leaf apex. I. Margin cells of leaf lobe. J. Median cells of leaf lobe. K. Basal cells of leaf lobe. L. Leaf lobule apex. M. Cross section of stem. (A-C, H-M from the lectotype; D-G from Gradstein 10324 (GOET)). 

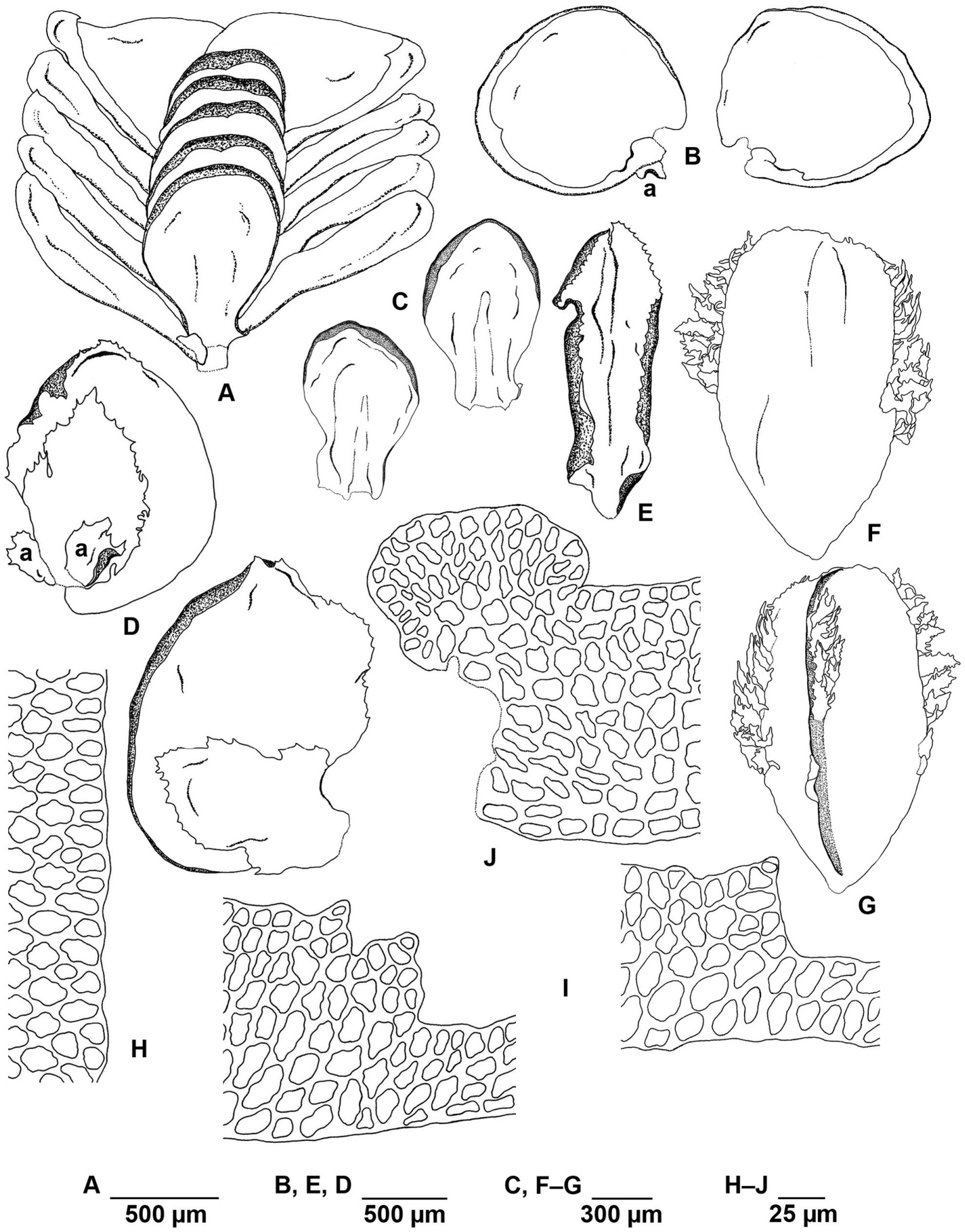

FIG. 17. Thysananthus gottschei var. continuus var. nov. A. Portion of shoot, ventral view. B. Leaves, ventral view: a = appendage. C. Underleaves, ventral view. D. Female bracts, ventral view: a = appendage. E. Female bracteole, ventral view. F. Perianth, dorsal view. G. Perianth, ventral view. H. Margin cells of leaf lobe. I. Leaf lobule apices. J. Leaf lobule base. (All from the lectotype). 

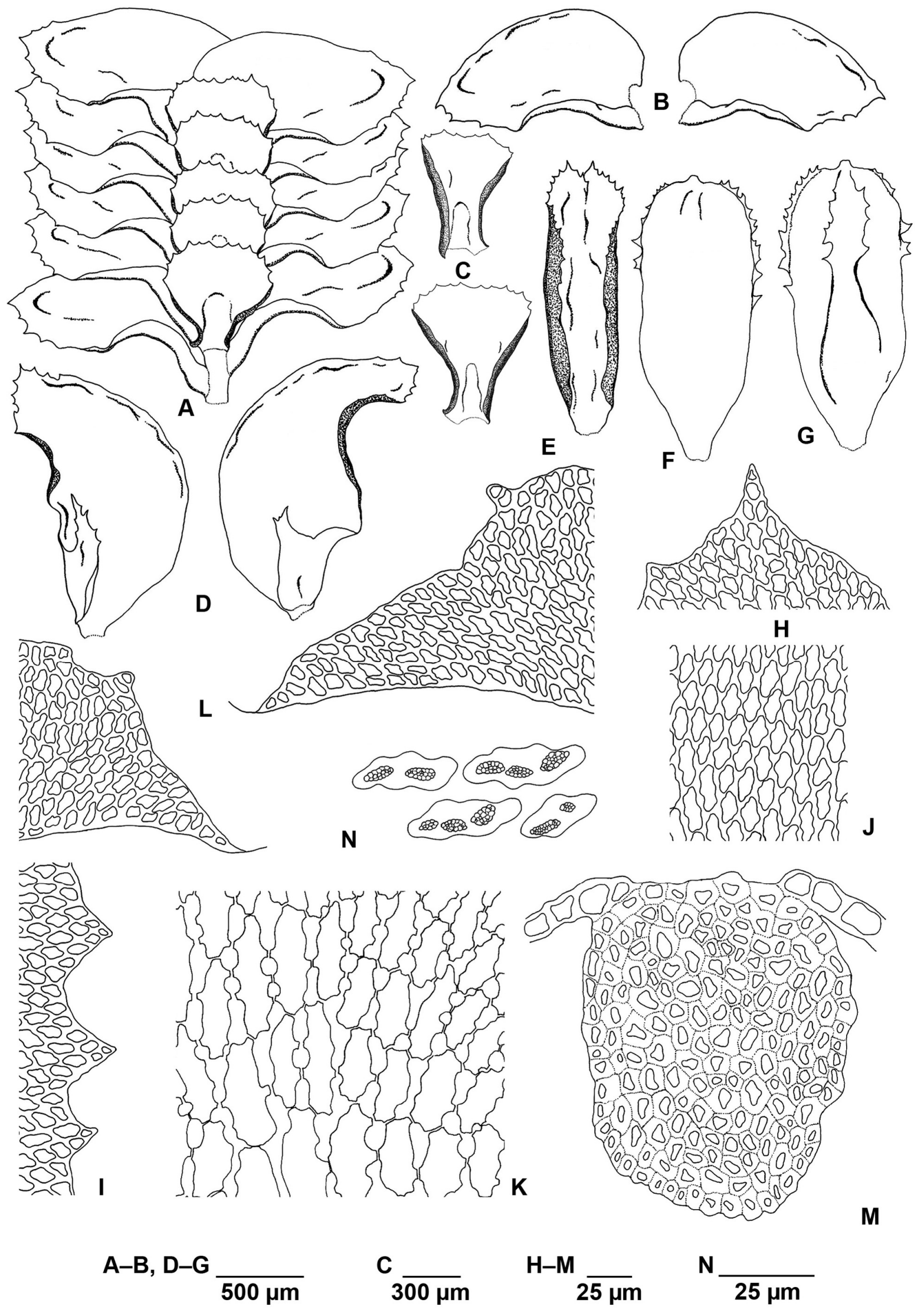

FIG. 18. Thysananthus spathulistipus (Reinw. et al.) Lindenb. A. Portion of shoot, ventral view. B. Leaves, ventral view. C. Underleaves, ventral view. D. Female bracts, ventral view. E. Female bracteole, ventral view. F. Perianth, dorsal view. G. Perianth, ventral view. H. Leaf apex. I. Margin cells of leaf lobe. J. Median cells of leaf lobe. K. Basal cells of leaf lobe. L. Leaf lobule apices. M. Cross section of stem. N. Oil bodies. (A-M from the holotype; N from Sukkharak 716 (BKF, GOET)). 
Chapter VI

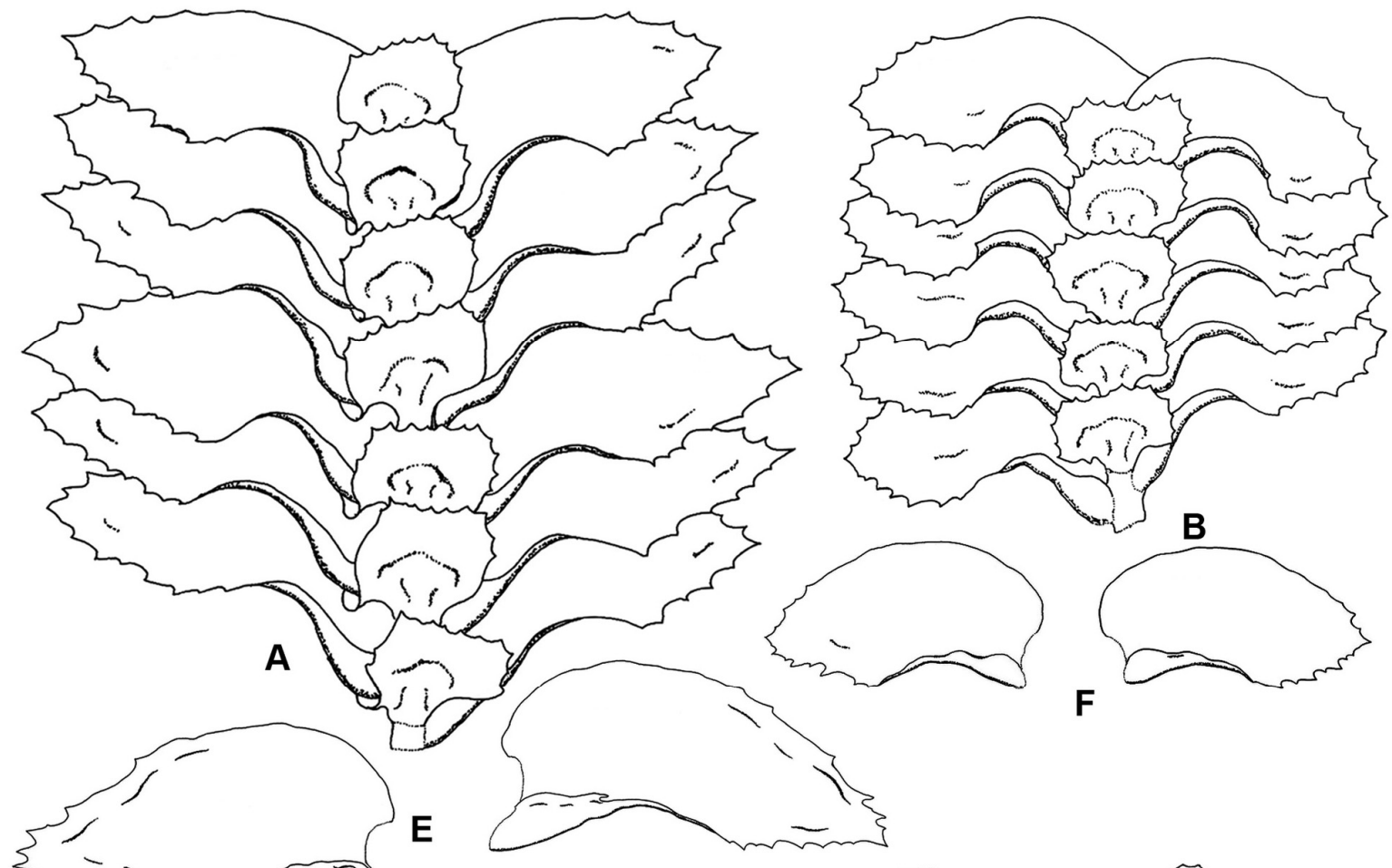

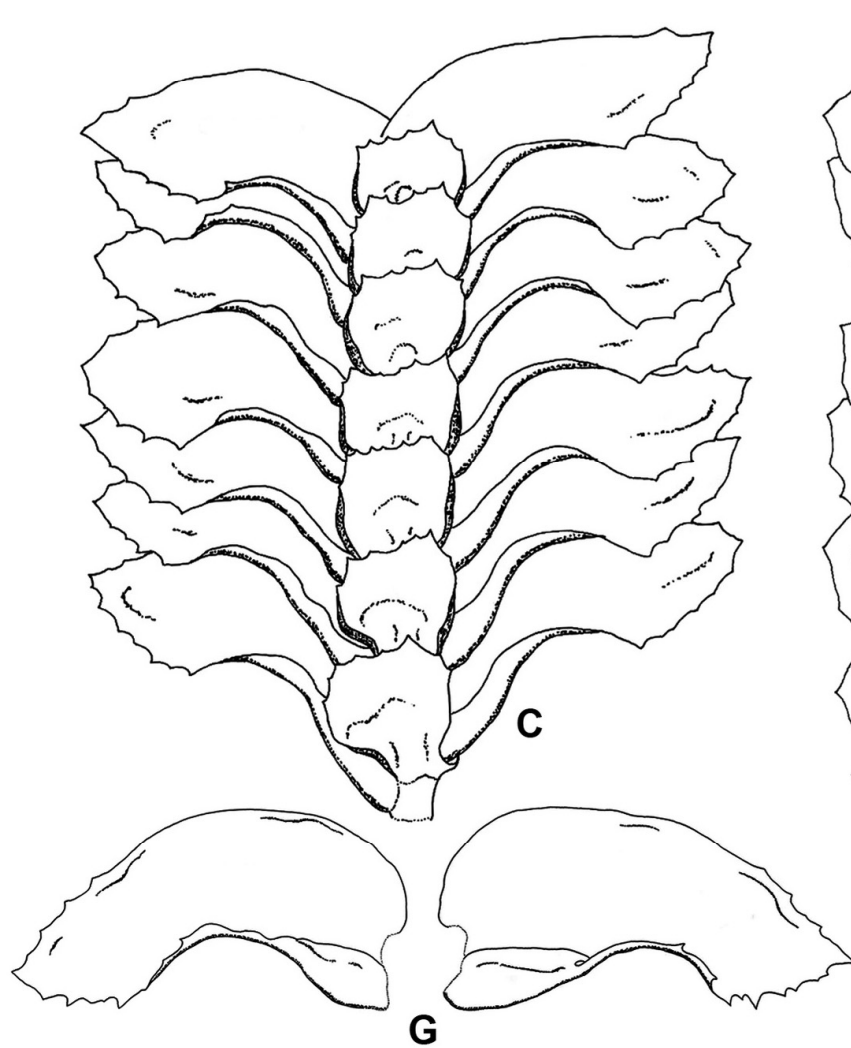

A-D

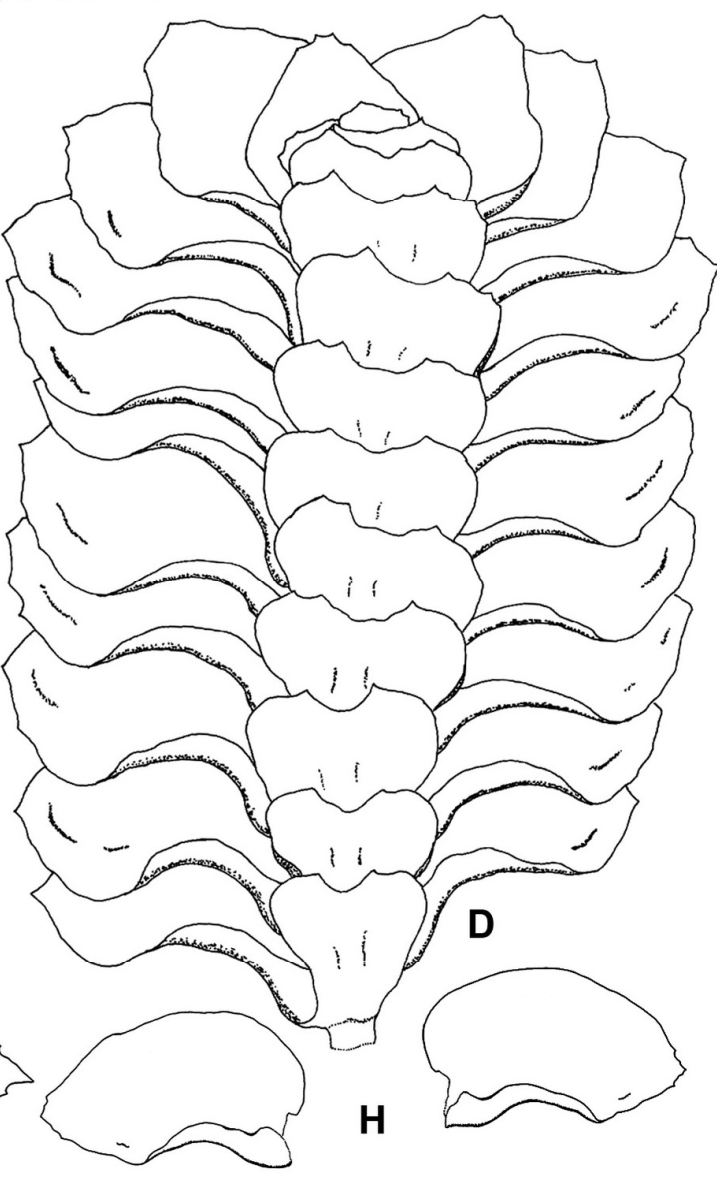

E-H

FIG. 19. Thysananthus spathulistipus (Reinw. et al.) Lindenb. A-D. Portion of shoot, ventral view. E-H. Leaves, ventral view. (A, E from the holotype of T. spathulistipus var. borneensis; B, F from holotype of T. minor; C, G from holotype of $T$. fuscobrunneus; D, H from holotype of T. triquetrus). 


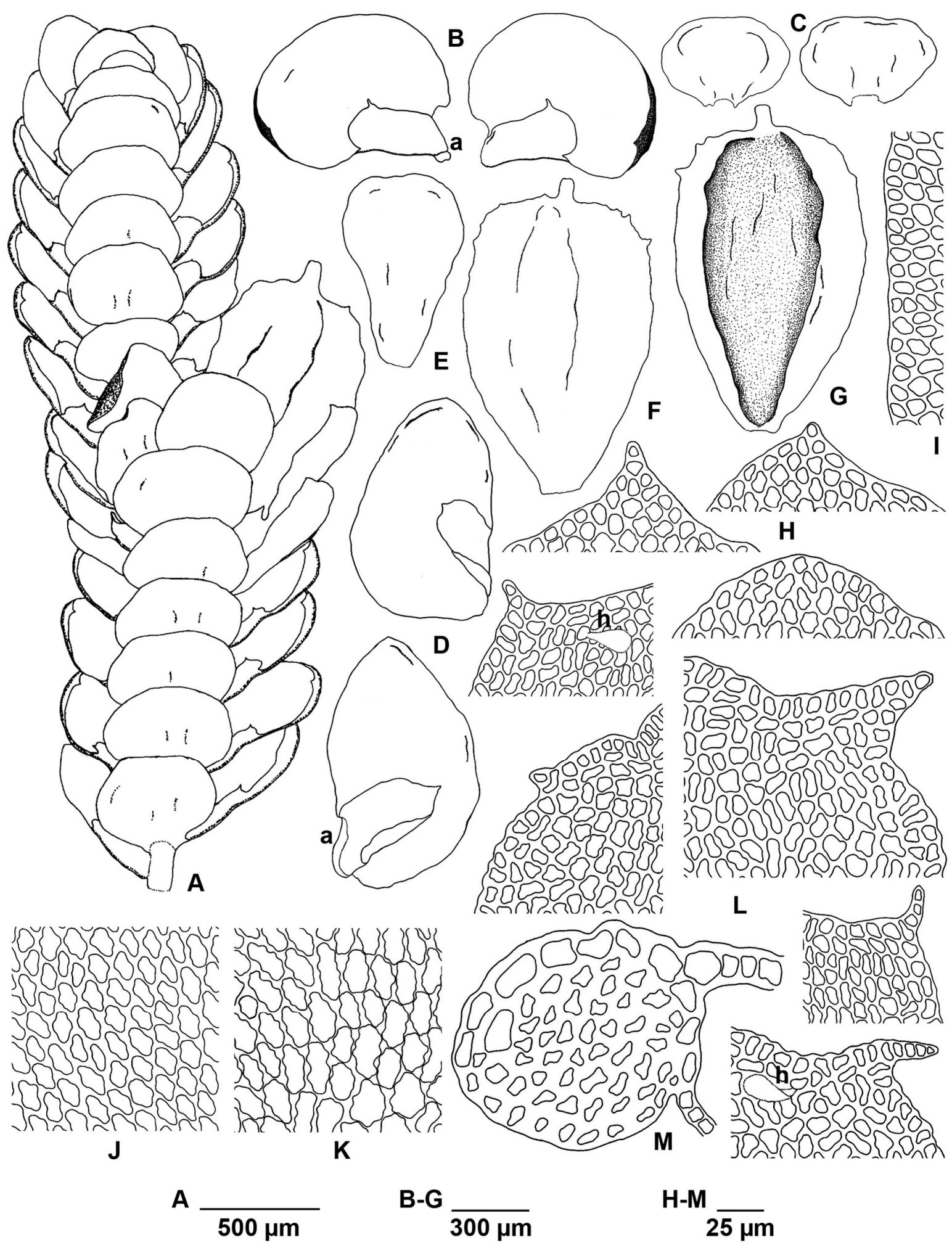

FIG. 20. Thysananthus anguiformis (Hook. f. \& Taylor) Steph. A. Portion of shoot, ventral view. B. Leaves, ventral view: a = appendage. C. Underleaves, ventral view. D. Female bracts, ventral view: a = appendage. E. Female bracteole, ventral view. F. Perianth, dorsal view. G. Perianth, ventral view. H. Leaf apices. I. Margin cells of leaf lobe. J. Median cells of leaf lobe. K. Basal cells of leaf lobe. L. Leaf lobule apices: $\mathrm{h}=$ hyaline papilla. M. Cross section of stem. (All from the lectotype). 


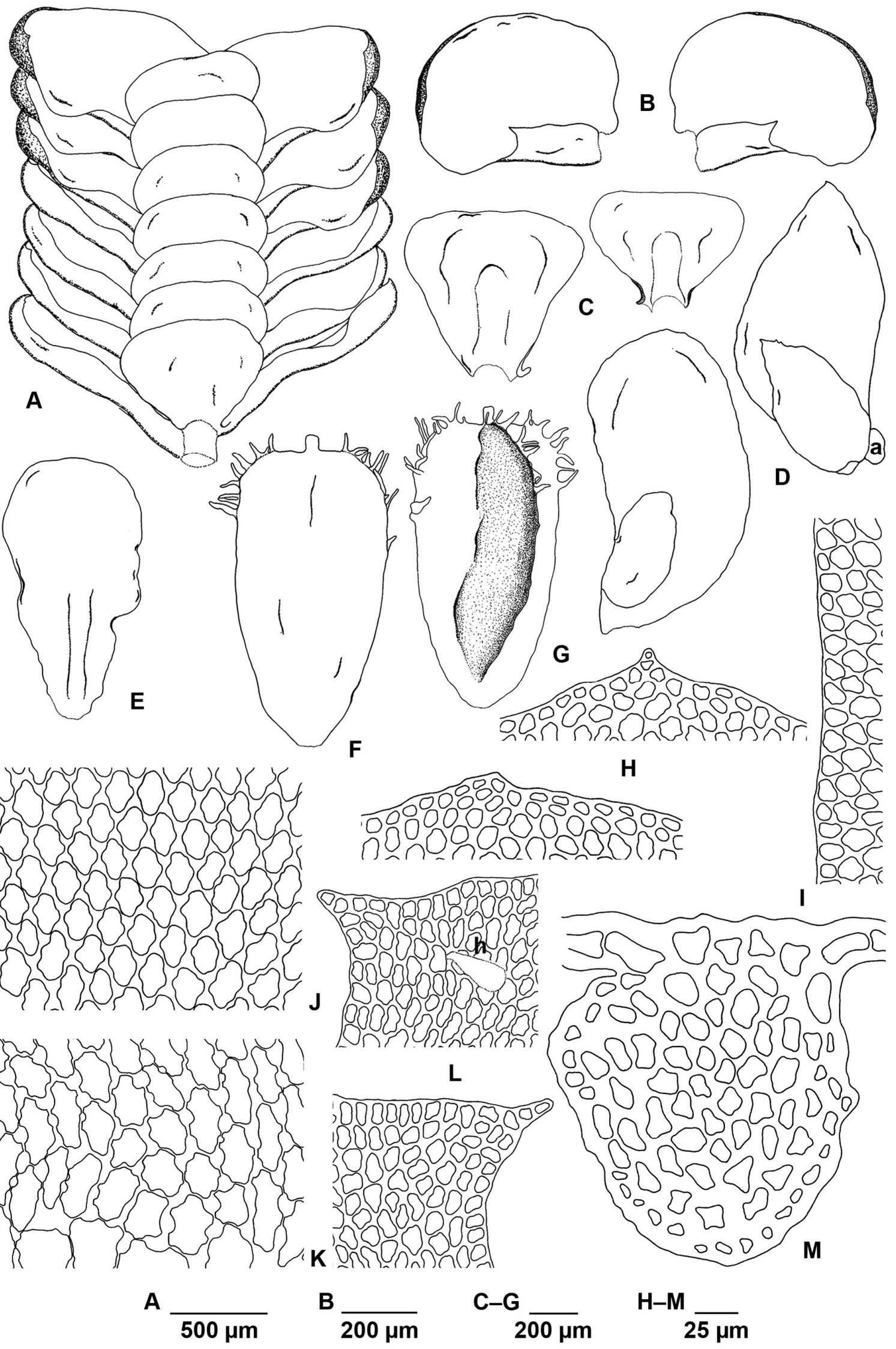

FIG. 21. Thysananthus pancheri (Steph.) Hürl. A. Portion of shoot, ventral view. B. Leaves, ventral view. C. Underleaves, ventral view. D. Female bracts, ventral view: a = appendage. E. Female bracteole, ventral view. F. Perianth, dorsal view. G. Perianth, ventral view. H. Leaf apices. I. Margin cells of leaf lobe. J. Median cells of leaf lobe. K. Basal cells of leaf lobe. L. Leaf lobule apices: $\mathrm{h}=$ hyaline papilla. M. Cross section of stem. (All from the lectotype). 


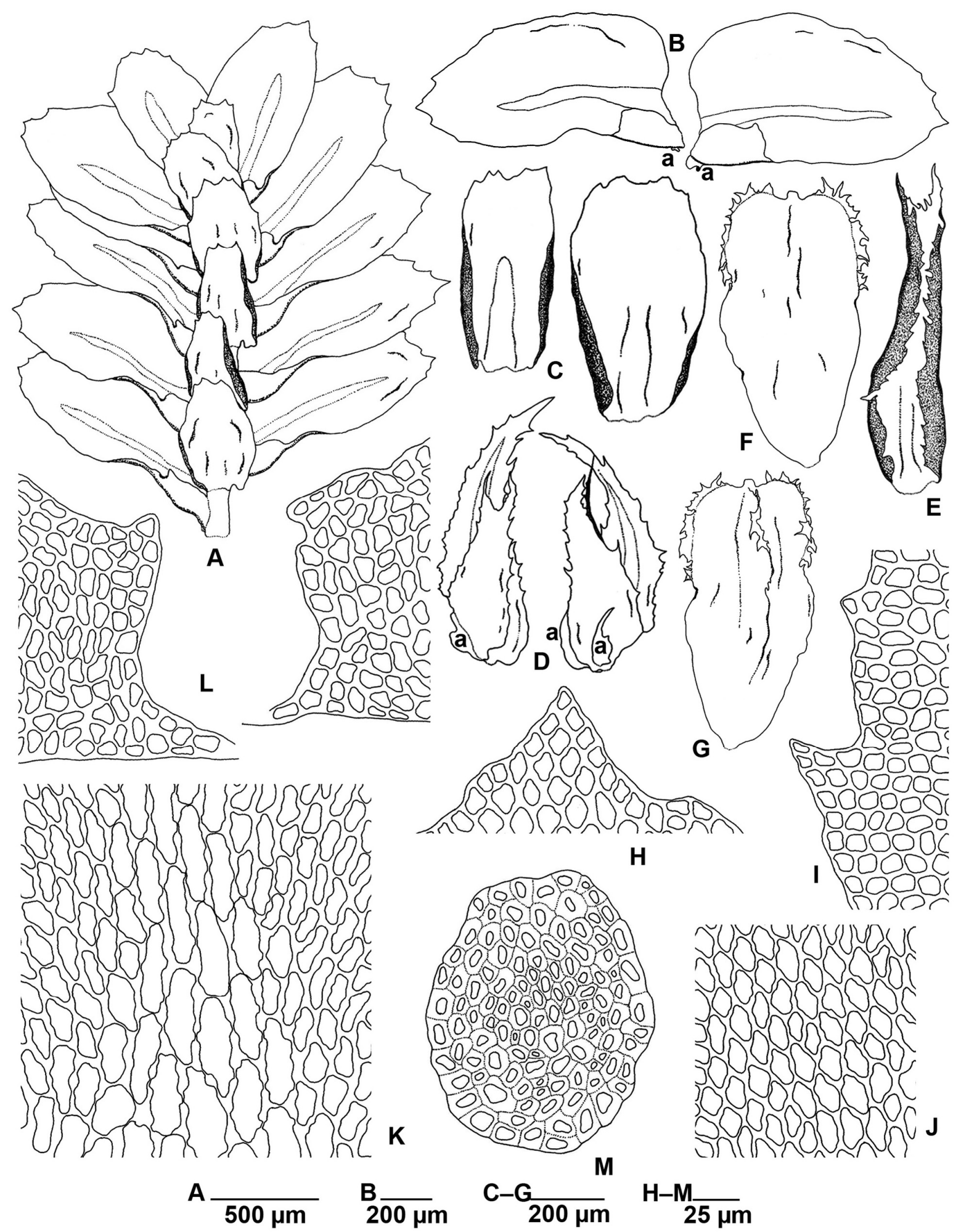

FIG. 22. Thysananthus fruticosus (Lindenb. \& Gottsche) Schiffn. A. Portion of shoot, ventral view. B. Leaves, ventral view: $\mathrm{a}=$ appendage. C. Underleaves, ventral view. D. Female bracts, ventral view: a = appendage. E. Female bracteole, ventral view. F. Perianth, dorsal view. G. Perianth, ventral view. H. Leaf apex. I. Margin cells of leaf lobe. J. Median cells of leaf lobe. K. Basal cells of leaf lobe, showing the vitta. L. Leaf lobule apices. M. Cross section of stem. (A-C, H-M from the lectotype; D-G from Brass 22185 (JE)). 


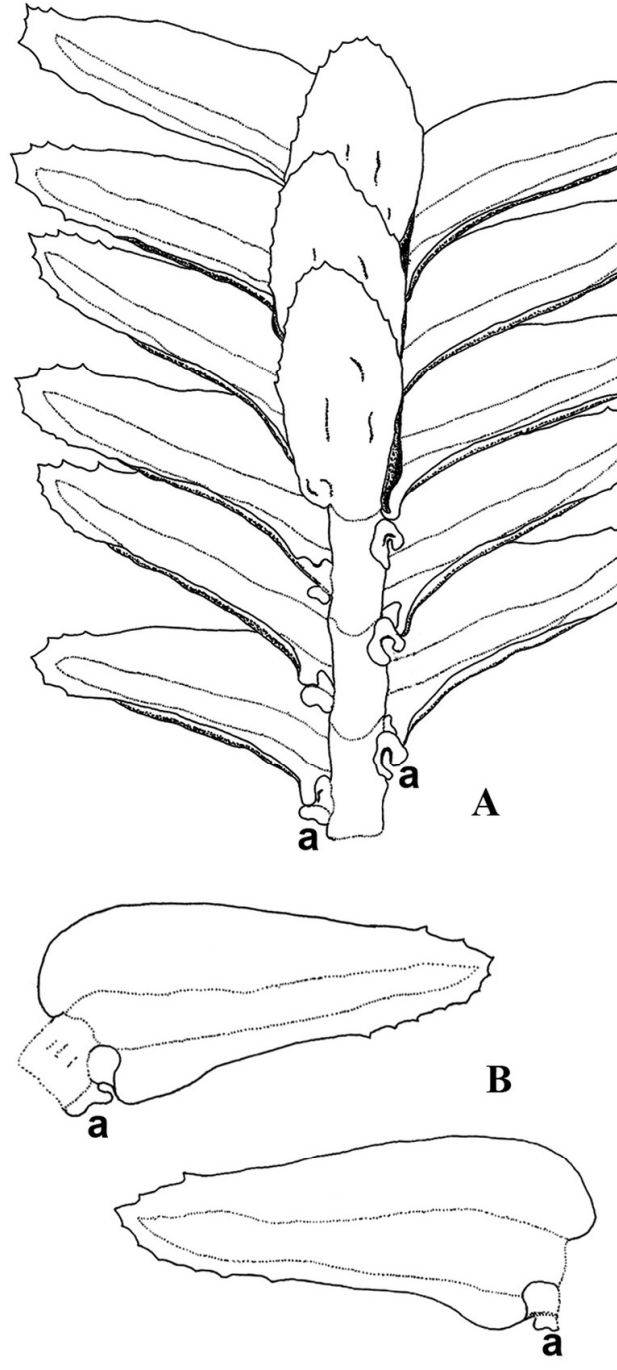

A

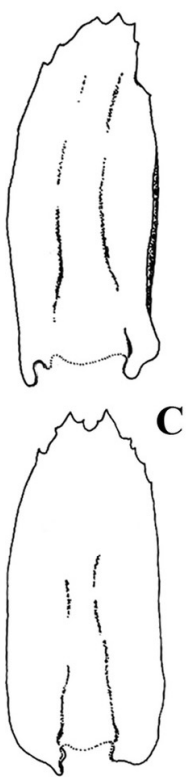

B-C
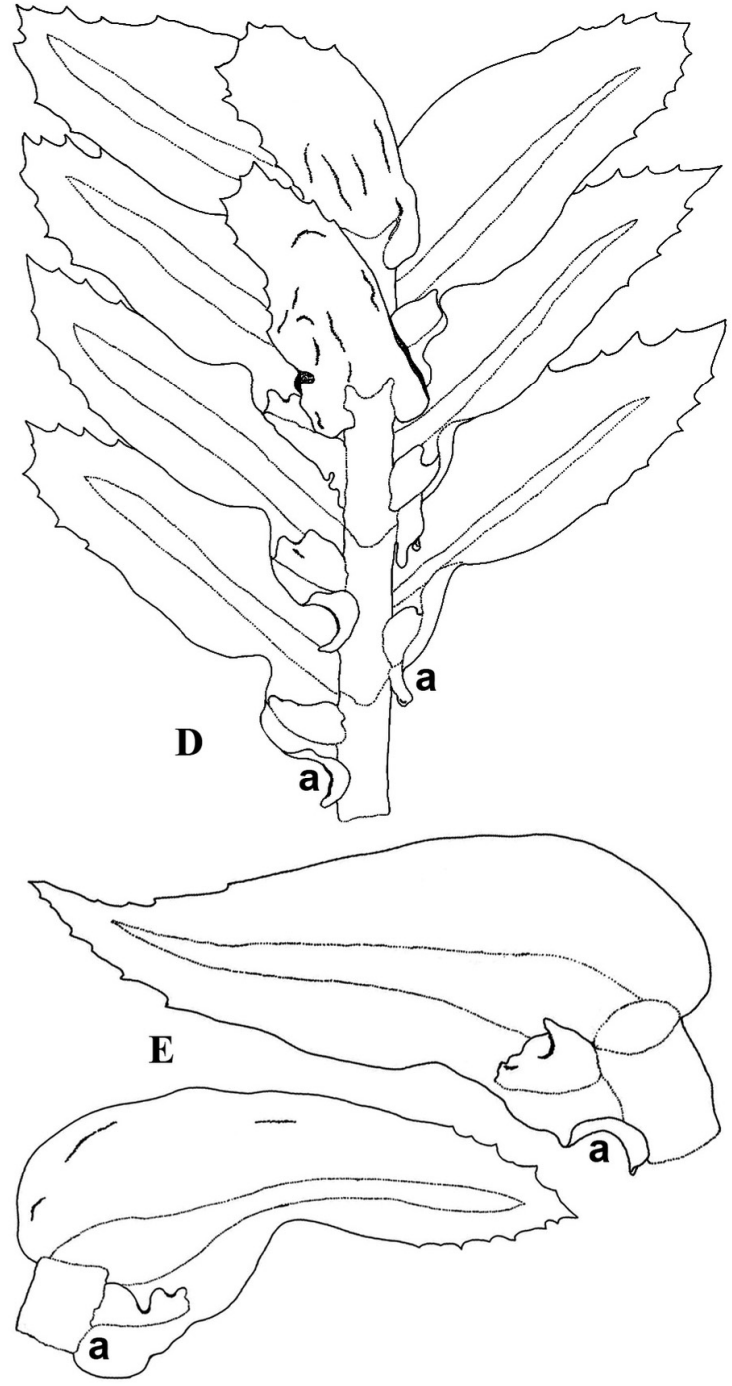

$D, E$

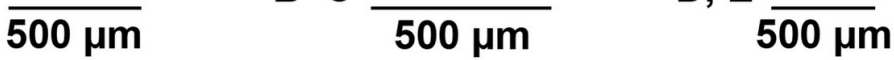

FIG. 23. Thysananthus fruticosus (Lindenb. \& Gottsche) Schiffn. A-B. Portion of shoot, ventral view: a = appendage. C-D. Leaves, ventral view: a = appendage. E. Underleaves, ventral view. (A, C, E from Beccari s.n. (JE); D, E from Streimann $25733(\mathrm{JE}))$. 


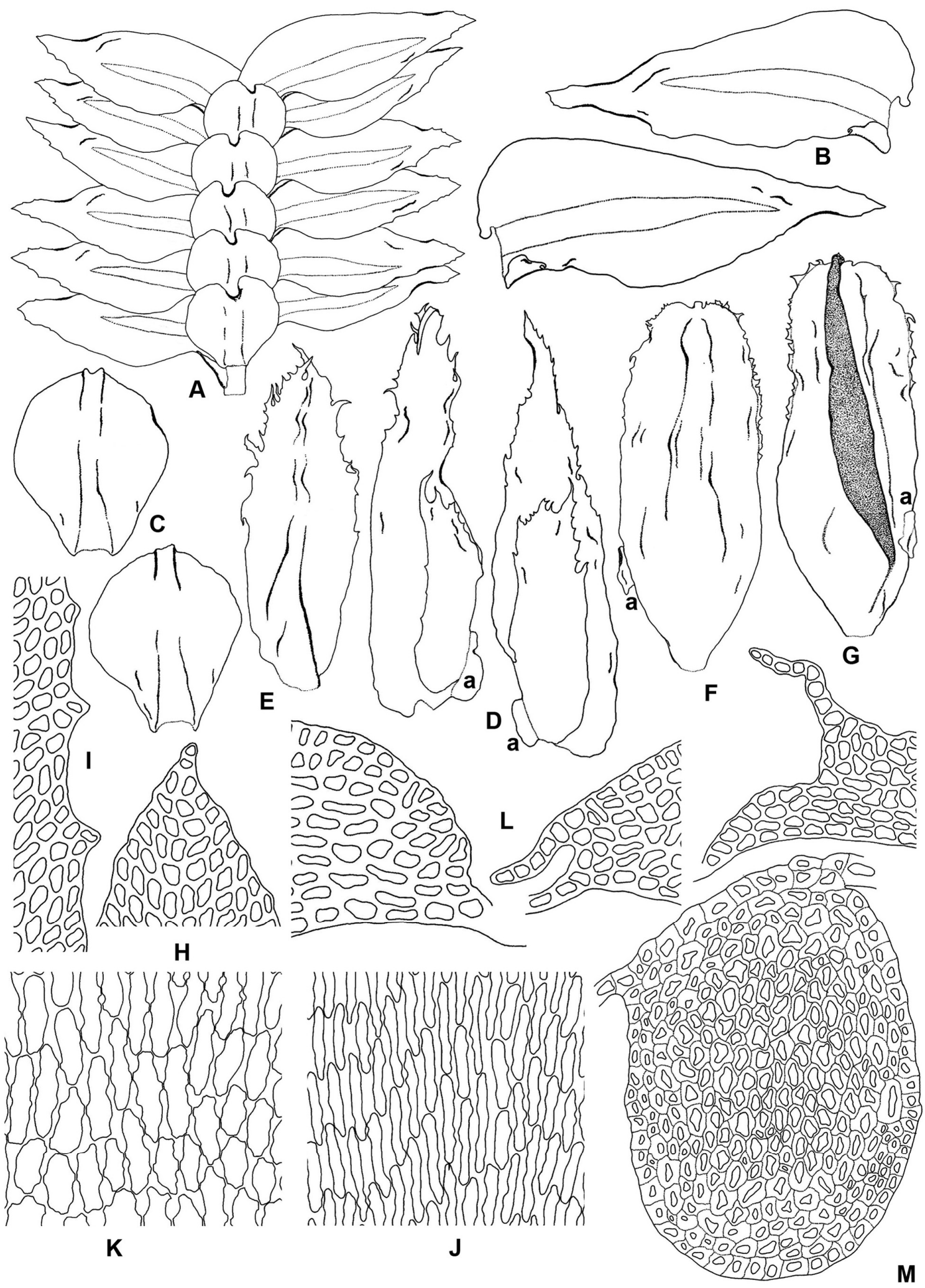

\section{A $500 \mu \mathrm{m}$ \\ B-G $500 \mu \mathrm{m}$ \\ H-M \\ $\overline{25 \mu \mathrm{m}}$}

FIG. 24. Thysananthus mollis Steph. A. Portion of shoot, ventral view. B. Leaves, ventral view. C. Underleaves, ventral view. D. Female bracts, ventral view: $\mathrm{a}=$ appendage. E. Female bracteole, ventral view. F. Perianth, dorsal view: $\mathrm{a}=$ appendage. G. Perianth, ventral view, a = appendage. H. Leaf apex. I. Margin cells of leaf lobe. J. Median cells of leaf lobe. K. Basal cells of leaf lobe. L. Leaf lobule apices. M. Cross section of stem. (All the holotype). 


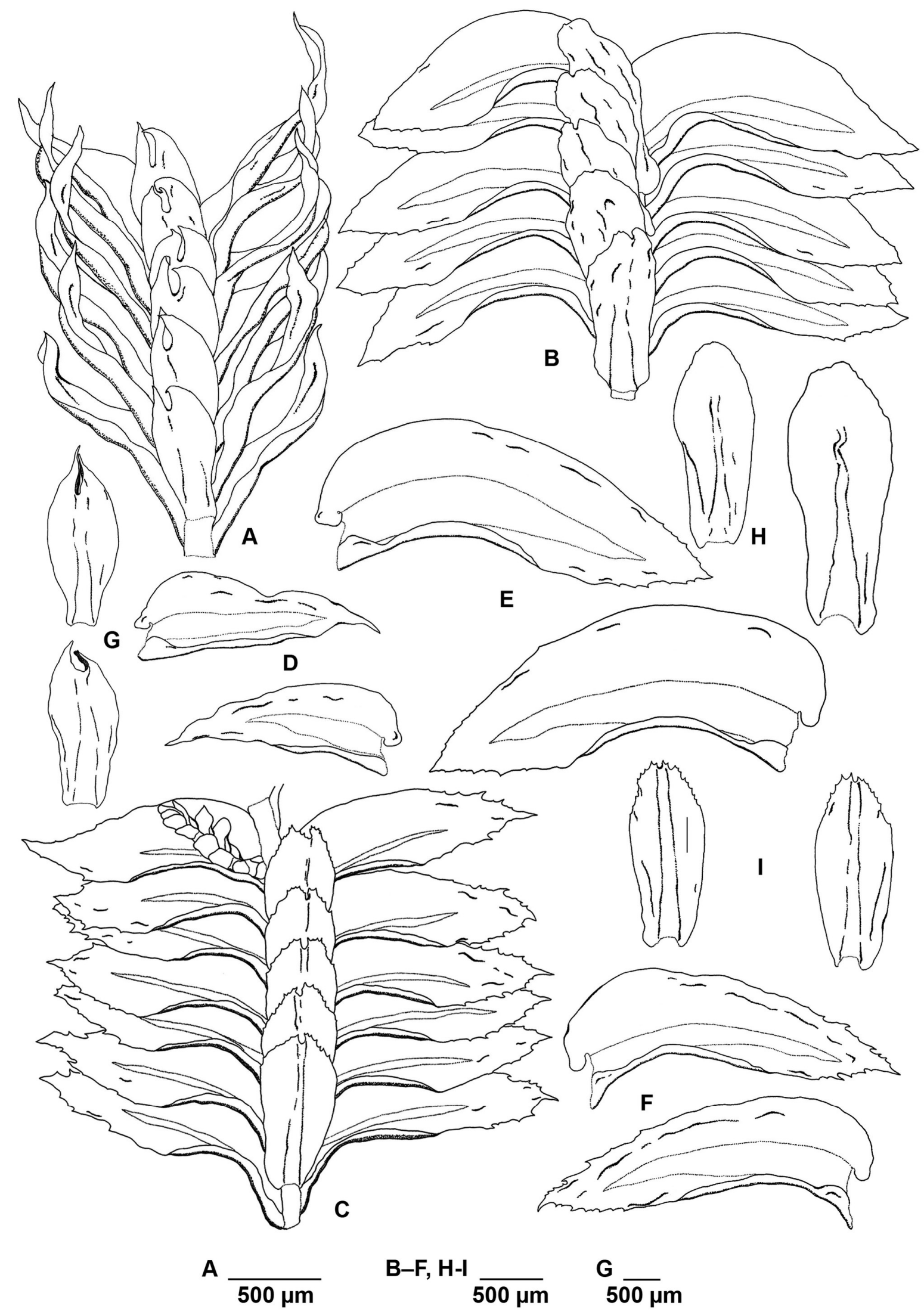

FIG. 25. Thysananthus mollis Steph. A-C. Portion of shoot, ventral view. D-F. Leaves, ventral view. G-I. Underleaves, ventral view. (A, D, G from Streimann \& Bellamy 13049 (JE); B, E, H from Streimann 26631 (JE); C, F, I from Gradstein 3792 (GOET)). 


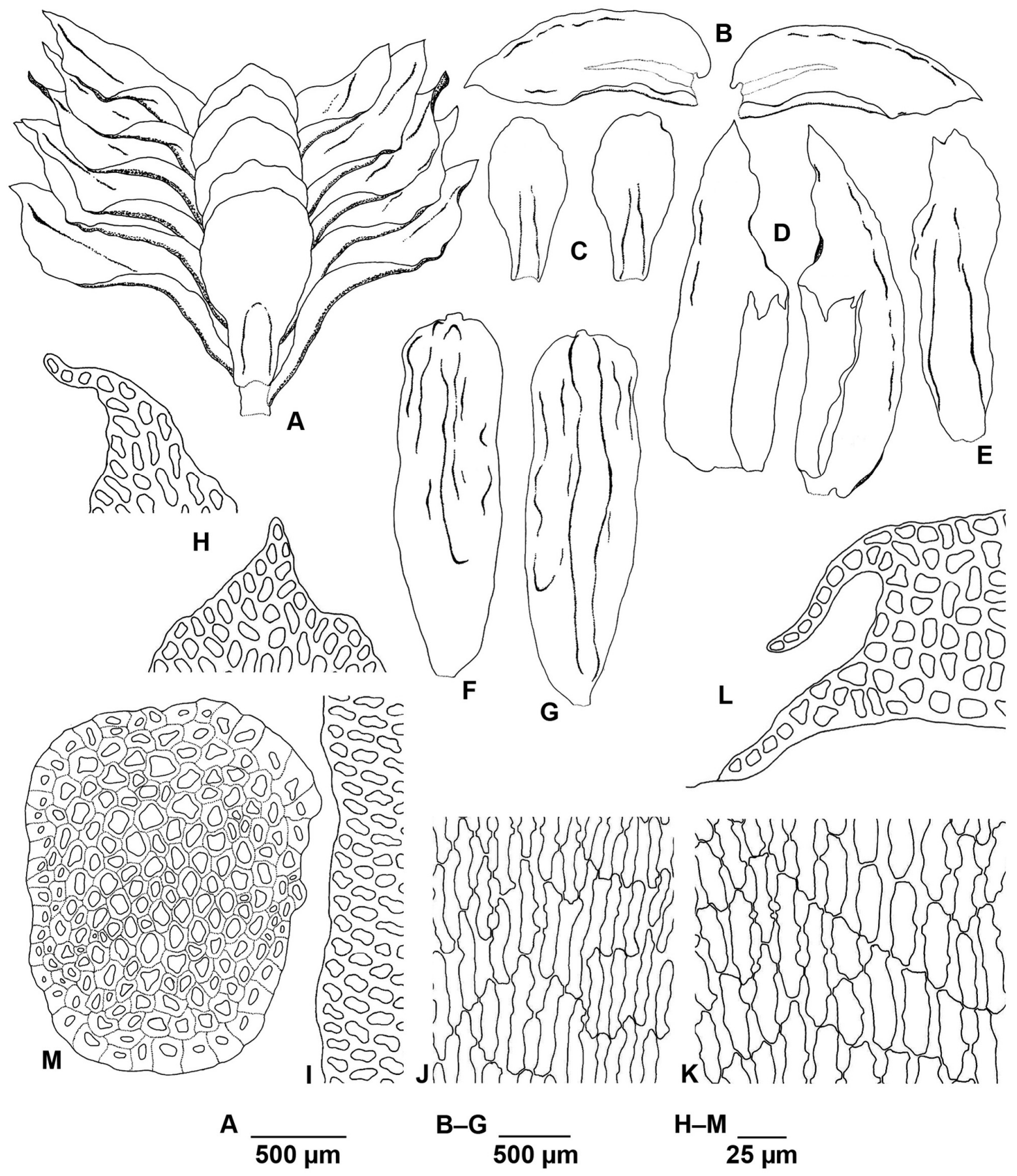

FIG. 26. Thysananthus montanus Gradst. et al. A. Portion of shoot, ventral view. B. Leaves, ventral view. C. Underleaves, ventral view. D. Female bracts, ventral view. E. Female bracteole. F. Perianth, dorsal view. G. Perianth, ventral view. H. Leaf apices. I. Margin cells of leaf lobe. J. Median cells of leaf lobe. K. Basal cells of leaf lobe. L. Leaf lobule apex. M. Cross section of stem. (All from the holotype). 


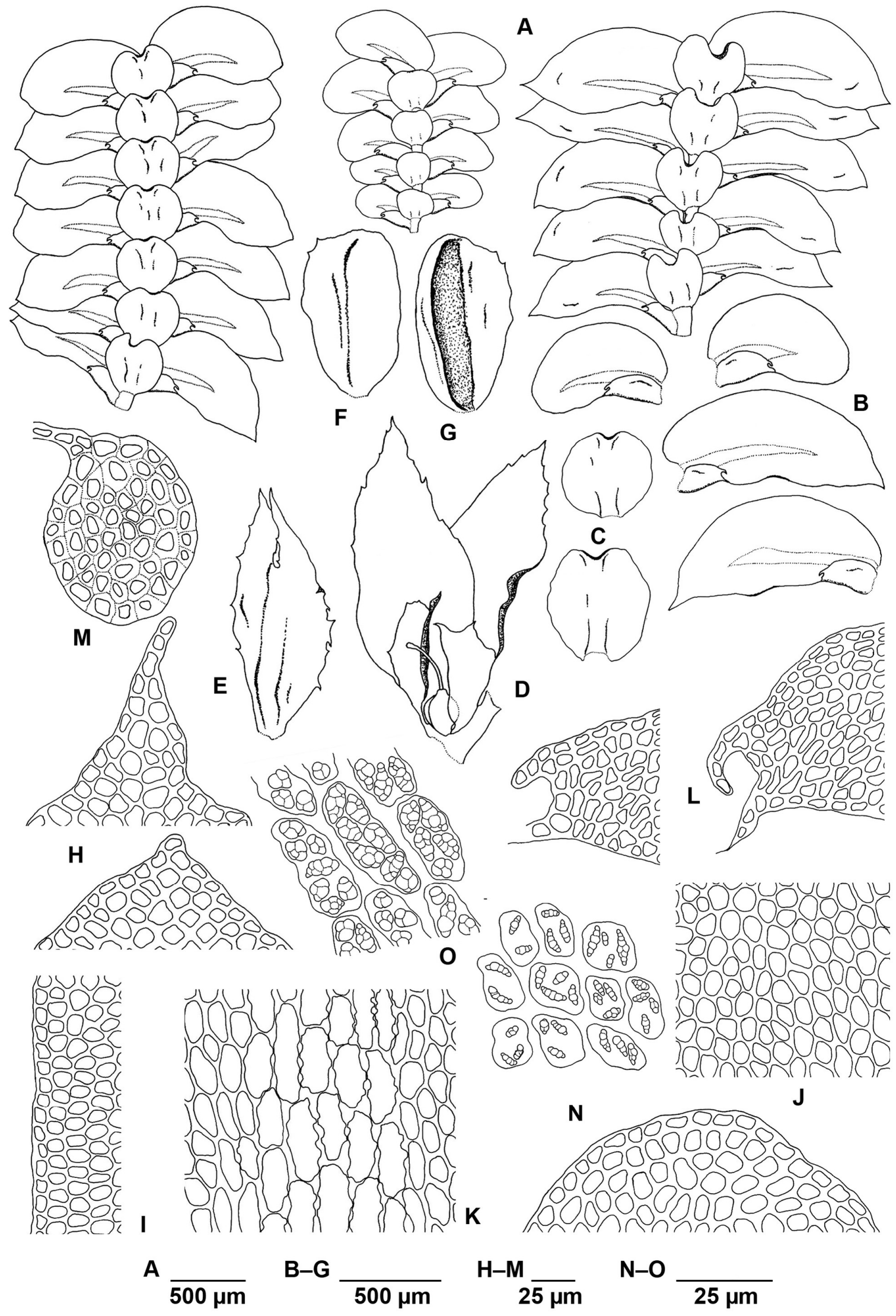

FIG. 27. Thysananthus retusus (Reinw. et al.) B. Thiers \& Gradst. A. Portion of shoot, ventral view. B. Leaves, ventral view. C. Underleaves, ventral view. D. Female bracts, ventral view. E. Female bracteole, ventral view. F. Perianth, dorsal view. G. Perianth, ventral view. H. Leaf apices. I. Margin cells of leaf lobe. J. Median cells of leaf lobe. K. Basal cells of leaf lobe, showing the vitta. L. Leaf lobule apices. M. Cross section of stem. N. Oil bodies, non-vittate cells. O. Oil bodies, vittate cells. (A-M from the holotype; N-O from Sukkharak 733 (BKF, GOET)). 


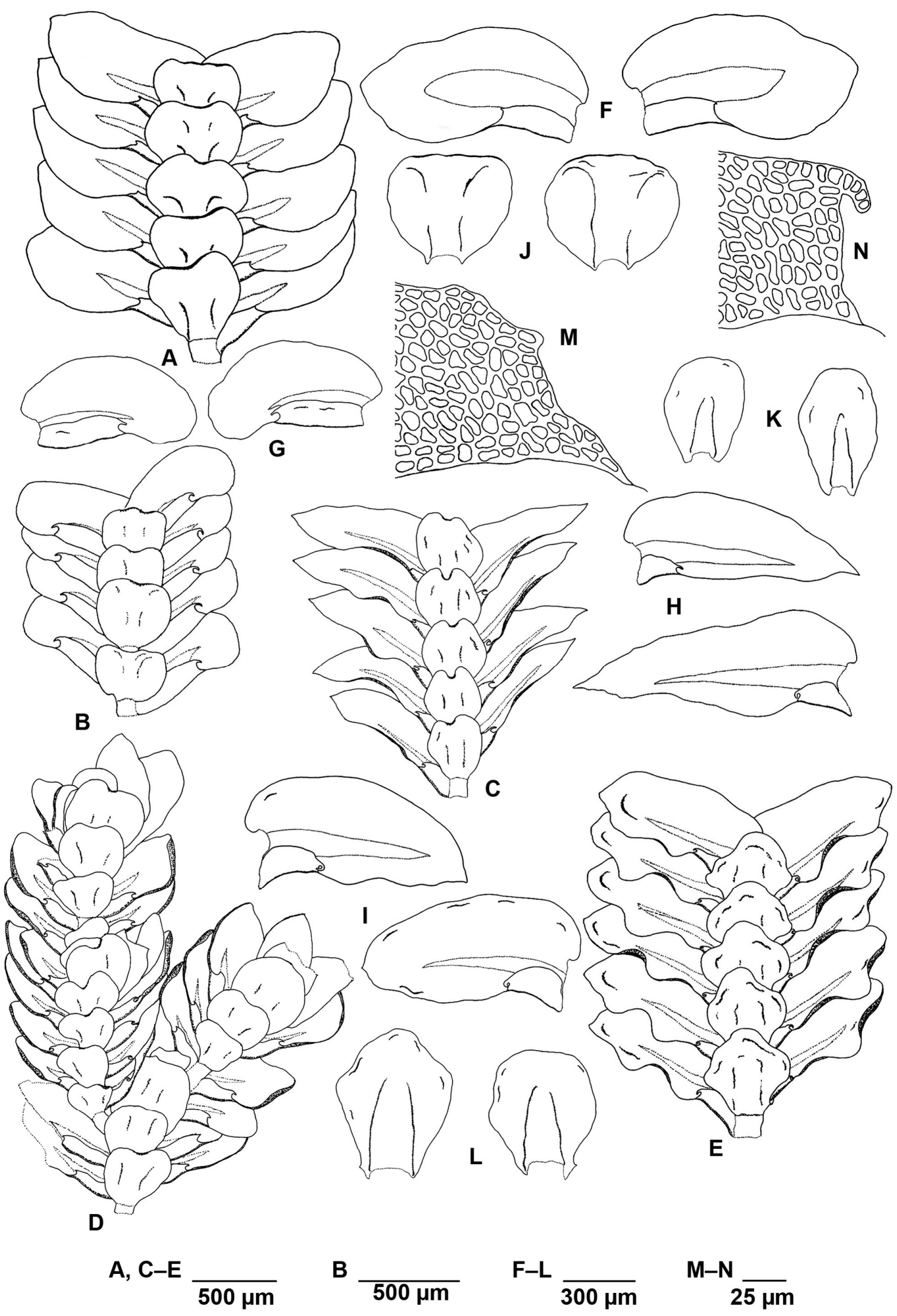

FIG. 28. Thysananthus retusus (Reinw. et al.) B. Thiers \& Gradst. A-E. Portion of shoot, ventral view. F-I. Leaves, ventral view. J-L. Underleaves, ventral view. M-N. Leaf lobule apices. (A, F, J, M from the holotype of T. australis; C, H, K, N from Gradstein 3963 (GOET); D, from the holotype; E, I, L from Degelius 223 (JE).—T. retusus subsp. sellingii (Hürl.) comb. nov. B. Portion of shoot, ventral view. G. Leaves, ventral view. (All from the holotype). 

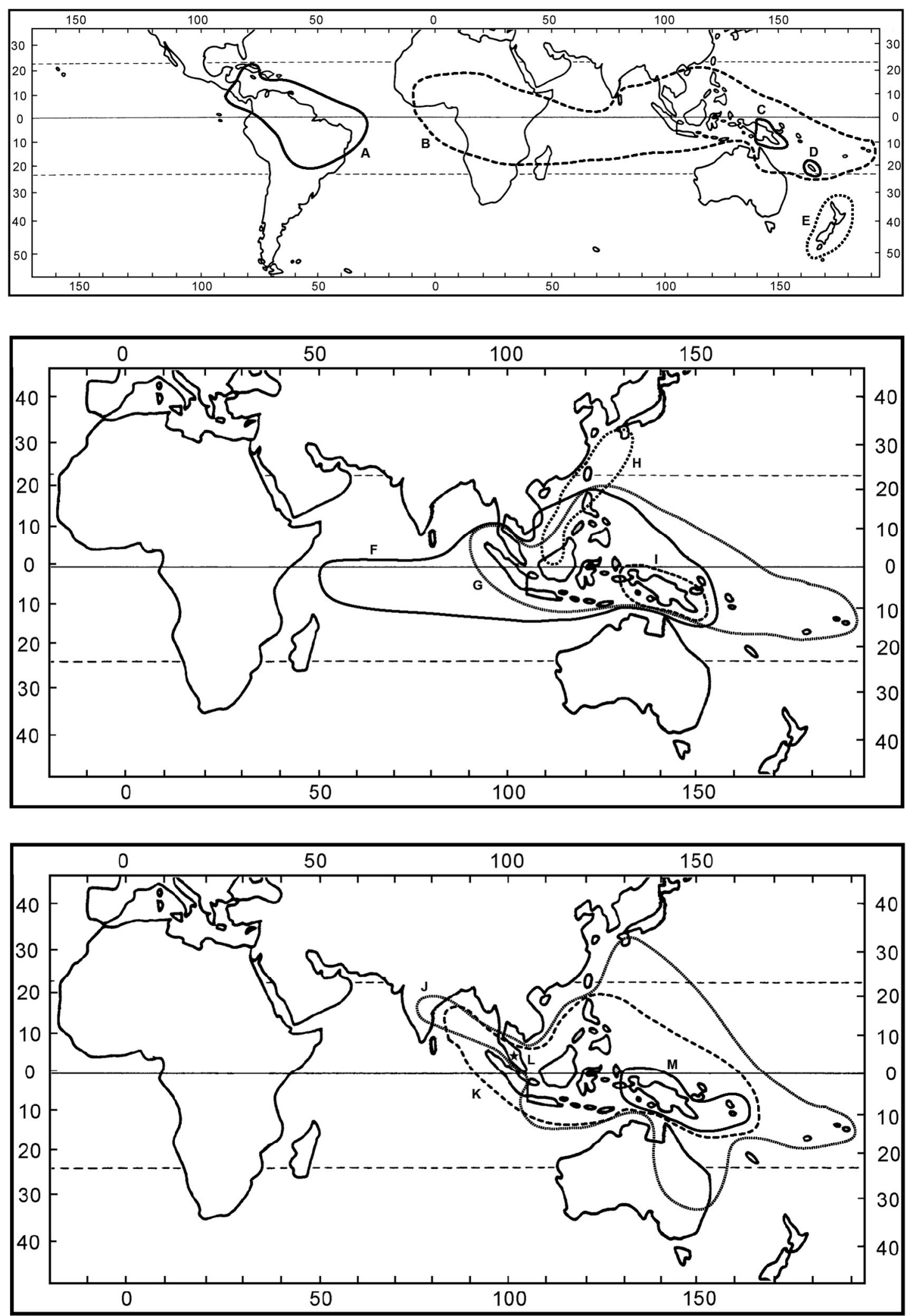

FIG. 29. Distribution of subg. Thysananthus species. A. Thysananthus amazonicus (Spruce) Schiffn. B. Thysananthus spathulistipus (Reinw. et al.) Lindenb. C. Thysananthus mollis Steph., Thysananthus montanus Gradst. et al. D. Thysananthus pancheri (Steph.) Hürl. E. Thysananthus anguiformis (Hook. f. \& Taylor) Steph. F. Thysananthus comosus Lindenb. G. Thysananthus fruticosus (Lindenb. \& Gottsche) Schiffn. H. Thysananthus aculeatus Herzog. I. Thysananthus appendiculatus Steph. J. Thysananthus retusus (Reinw. et al.) B. Thiers \& Gradst. K. Thysananthus convolutus Lindenb., Thysananthus gottschei (Jack \& Steph.) Steph. L. Thysananthus combinatus sp. nov. M. Thysananthus discretus Sukkharak \& Gradst 


\section{DECLARATION OF THE AUTHOR'S OWN CONTRIBUTION TO THE PAPERS}

I am the overall author of all manuscript presented in this thesis. I did not use any other sources as the ones indicated in the chapters. This thesis has not been submitted previously in any form for another degree at any university or institution.

Phiangphak Sukkharak

Göttingen, 27 April 2011 


\section{CURRICULUM VITAE}

Name

Phiangphak Sukkharak

Born

7 March 1982, Nan, Thailand

05/1998 - 03/2001 Yupparaj Wittayalai School, Chiang Mai, Thailand supported by the Development and Promotion of Science and Technology talents project (DPST), a Royal Thai government scholarship.

05/2001 - 03/2005 B.Sc. in Biology, Chiang Mai University, Chiang Mai, Thailand. $\left(2^{\text {nd }}\right.$ Class Honors) supported by the Development and Promotion of Science and Technology talents project (DPST), a Royal Thai government scholarship.

05/2005-03/2008 M.Sc. in Botany, Chulalongkorn University, Bangkok, Thailand supported by the Development and Promotion of Science and Technology talents project (DPST), a Royal Thai government scholarship.

08/2008 - 06/2011 Ph.D in Biodiversity and Ecology, University of Göttingen supported by a Royal Thai government scholarship in cooperation with the German Academic Exchange Service (DAAD).

07/2011 onwards Lecturer at Faculty of Science, Burapha University, Chonburi, Thailand. 